Ana Celina Junqueira de Aquino Barretto de Vasconcellos

\title{
A CIVILIZAÇÃO ESCOLAR E AS CAMADAS POPULARES: a tecitura do cotidiano escolar
}

Tese de Doutorado, apresentada ao Programa de Pós-Graduação em Educação, Faculdade de Educação da USP

Orientadora: $\operatorname{Prof}^{\mathrm{a}} \mathrm{D}^{\mathrm{ra}}$ Mônica Guimarães Teixeira do Amaral 
AUTORIZO A REPRODUÇÃO E DIVULGAÇÃO TOTAL OU PARCIAL DESTE TRABALHO, POR QUALQUER MEIO CONVENCIONAL OU ELETRÔNICO, PARA FINS DE ESTUDO E PESQUISA, DESDE QUE CITADA A FONTE.

Catalogação na Publicação

Serviço de Biblioteca e Documentação

Faculdade de Educação da Universidade de São Paulo

37.09 Vasconcellos, Ana Celina Junqueira de Aquino Barretto de

V331c A civilização escolar e as camadas populares: a tecitura do cotidiano escolar/ Ana Celina Junqueira de Aquino Barretto de Vasconcellos; orientação Mônica Guimarães Teixeira do Amaral.-- São Paulo: s.n., 2009.

211 p. il.; tabs.; anexo

Tese (Doutorado - Programa de Pós-Graduação em Educação. Área de Concentração: Psicologia e Educação) - - Faculdade de Educação da Universidade de São Paulo.

1. Escolarização 2. Civilização 3. Globalização 4. Cultura escolar 5. Classe baixa 6. Favelas I. Amaral, Mônica Guimarães Teixeira do, orient. 


\section{FOLHA DE APROVAÇÃO}

Ana Celina Junqueira de Aquino Barretto de Vasconcellos

A civilização escolar e as camadas populares: a tecitura do cotidiano escolar

Tese de Doutorado, apresentada ao Programa de Pós-Graduação

em Educação, Faculdade de

Educação da USP

Orientadora: Prof $^{\mathrm{a}} \mathrm{D}^{\mathrm{ra}}$ Mônica Guimarães Teixeira do Amaral

Aprovado em:

Banca Examinadora

Prof. Dr.

Instituição:

Assinatura:

Prof. Dr.

Instituição:

Assinatura:

Prof. Dr.

Instituição:

Assinatura:

Prof. Dr.

Instituição:

Assinatura:

Prof. Dr.

Instituição:

Assinatura: 
Em memória de meu pai 
Para o Tunico, um homem bom que divide sua vida comigo Para meus filhos Georges-Antoine e Camila, Paula e Pedro e Teresa, mais amados, impossível! Para minha mãe, Evangelina, casa-mãe que abriu espaço para meus estudos Para meus irmãos e irmãs por tantas coisas compartilhadas, Para meus netos Pierre-Antoine, Stella e Joaquim, com quem me maravilho com a vida Para os netos queridos Maria Beatriz e Antonio Pedro, presentes que a vida me deu obrigada 


\section{Agradecimentos}

À professora Mônica Amaral, pela disponibilidade com que me acolheu, pela força que transmitiu e pelas inúmeras horas de cuidadosa orientação.

A professora Carlota Boto, pela mão amiga que me estendeu, apoio e compreensão sempre.

À Universidade de São Paulo pela oportunidade de realização do curso de Doutorado.

Aos professores e colegas da Universidade de São Paulo, que tanto contribuíram para o meu crescimento acadêmico e profissional.

Aos professores, à coordenação e à Direção do Centro Popular Stella Maris pelo exemplo que dão, pela generosidade que oferecem e pela disponibilidade com que acolhem.

Às crianças, suas famílias e funcionários do Stella Maris, pela confiança e cooperação que depositaram neste trabalho.

À Márcia Simi e Jurema Diógenes Corrêa Martins pelo incentivo e abraço amigo que me deram.

À Maria Luiza Teixeira, Maria Apparecida Mamede Neves e Maria Cecília Almeida e Silva por acreditarem em mim.

À Madalena Freire que tem a árdua missão de fazer brotar educadores em professores.

Às minhas amigas que compreenderam minhas ausências e dividiram esse tempo comigo.

À Andrea Argollo pelo valioso tempo e apoio incondicional para a realização deste trabalho.

A todos os colegas da equipe do NOAP e do ISEPS, pelo apoio e compreensão, bem como às colegas e alunas do CEPERJ, que tanto contribuíram para a realização deste trabalho. 


\section{RESUMO}

\section{VASCONCELLOS, A. C. J. A. B. A civilização escolar e as camadas populares: a tecitura}

do cotidiano escolar. 2009. 211 p. Tese (doutorado) - Faculdade de Educação, Universidade de São Paulo, São Paulo, 2009.

Esta tese consistiu em uma investigação do trabalho concreto em sala de aula das $5^{\mathrm{a}} \mathrm{e}$ $6^{a}$ séries do Ensino Fundamental em um colégio particular religioso da cidade do Rio de Janeiro - próximo à Favela do Vidigal e da Chácara do Céu - que fez uma opção inovadora para atender as camadas populares dessas comunidades. Foi a história dessa "opção pelos pobres" que chamou nossa atenção, uma vez que acenava com a possibilidade de alguma atuação transformadora no sentido de atender uma população desfavorecida. A literatura pedagógica centrada sobre o que hoje se tem nomeado cultura escolar compreende que o ritual da própria organização interna a cada escola configura um feixe de rotinas, usos e costumes, saberes e valores, que não apenas fazem parte da instituição, mas, sobretudo, "fazem" a instituição. O principal eixo de análise foi de perscrutar esse universo cultural específico dessa escola para aferir o que se passava no seu dia-a-dia. Compreender tais formas requer do investigador uma atenção mais detida sobre: o que se passa em sala de aula, o que acontece nos corredores com as turmas, as constatações da equipe administrativa, as disposições dos professores, os depoimentos dos pais dos alunos, os sinais mediante os quais os alunos registram sua percepção da vida escolar. Busca compreender as implicações socioculturais e alterações do projeto político e pedagógico do Centro Popular Stella Maris, que antes atendia alunos de classe média e média alta, e que, mantendo o mesmo corpo docente, passou a atender as camadas populares. As estratégias usadas na pesquisa de campo foram: observação da sala de aula, estudos de caso e entrevistas com os principais atores: alunos, professores, coordenadores e mães da comunidade atendida. $\mathrm{Na}$ análise dos dados tivemos como categorias: a cultura tanto na visão da comunidade como na visão dos professores e coordenadores; a escola na perspectiva dos pais da comunidade e a visão da comunidade do ponto de vista dos professores e coordenadores; as relações pedagógicas e o estabelecimento de vínculos; e as estratégias e recursos pedagógicos nas formas de ensinar. Pretendemos com essa pesquisa trazer para domínio público essa inovação que re-significa o espaço escolar para as camadas populares, com o intuito de auxiliar a escola pública a pôr em prática experiências inovadoras no que diz respeito à possibilidade da superação das dificuldades de aprendizagem do corpo discente a partir da escola. Os estudos de Souza Patto, Bourdieu e Dubet, entre outros, nortearam nossa pesquisa e fundamentaram nossas análises sobre essa experiência educativa. Nossas conclusões foram que a escola na modernidade apresentou progressivamente seu aspecto civilizador - ou o desejo de inscrever, na formação das crianças e dos jovens, um dado modelo cultural prévio e anteriormente prescrito - que ainda se encontra presente na atualidade e, em particular, nas experiências que pretendem oferecer um ensino de qualidade às camadas populares.

Palavras-chave: escolarização - civilização escolar - mundialização - cultura - camadas populares - favelas 


\begin{abstract}
VASCONCELLOS. A. C. J. A. B. Educational civilization and lower social class: the tissue of a school routine. 211 p. Thesis (doctoral) - Faculdade de Educação, Universidade de São Paulo, São Paulo, 2009.
\end{abstract}

This thesis consisted on an investigation into the practical work in the classrooms of $5^{\text {th }}$ and $6^{\text {th }}$ grades of Elementary School in a private religious school in Rio de Janeiro - close to Favela do Vidigal and Chacara do $\mathrm{Ceu}$ - which had made the innovative choice of attending to the lower class from these communities. It was "their option for the poor" which drew our attention as it waved the possibility of some transforming act as they were attending to a disadvantaged population. The literature on education centered in what today is called school culture understands that the ritual of every school internal organization frames a beam of routines, uses and costumes, knowledge and values which are not only part of the institution but above all they "form" the institution. The main axis of analysis was to look round this school's specific cultural universe to see what was happening in their daily life. For the comprehension of such forms the researcher is requested a more attentive look upon: what is going on in the classroom, what happens with the groups along the corridors, the administrative staff's observations, the teachers' dispositions, the students' parents' statements, the signs through which the students register their perception about life at school. He sought to understand the socio-cultural implications and changes in the politic-pedagogical project by the Centro Popular Stella Maris which had previously attended to middle and upper-class students and now attends to the lower class and kept on with the same board of teachers. The strategies used in the field survey were observation in the classroom, case studies and interviews with the key stakeholders: students, teachers, coordinators and mothers from the community. For the data analysis we established as categories: culture as seen by the community and according to teachers' and coordinators' view; the school viewed by the community parents and the teachers' and coordinators' view of the community; the pedagogical relations and the establishment of ties; the strategies and pedagogical resources used for teaching. With this research we intend to bring this innovation into public knowledge as it re-signifies school environment for the lower class in order to assist public schools to put into practice innovative actions in what concerns to the possibility of overcoming students' difficulties in learning by means of the school. Studies by Souza Patto, Bourdieu and Dubet among others guided our research and based our analysis on this educational experience. Our conclusions were that the school in modernity has gradually presented its civilizing aspect or its desire to inscribe a previous cultural model, prescribed beforehand, in children's and youth education - which is still present today and particularly in the practices which intend to offer good quality schooling to lower classes.

Key-words: schooling - educational civilization - globalization - culture - lower class - favela 


\section{SUMÁRIO}

INTRODUÇÃO

CAPÍTULO 1 - UMA ABORDAGEM HISTÓRICO-CONCEITUAL DE CULTURA

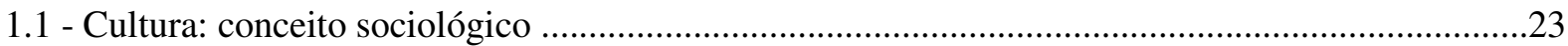

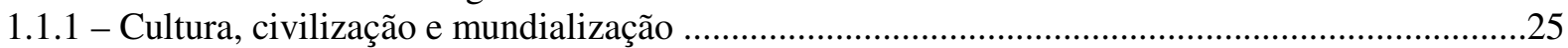

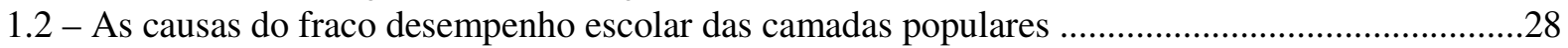

1.3 - Os capitais: econômico, cultural, social e simbólico à luz de Bourdieu .........................................31

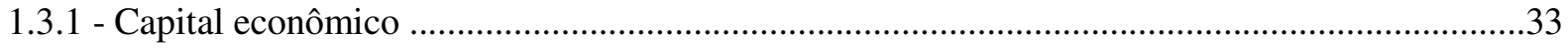

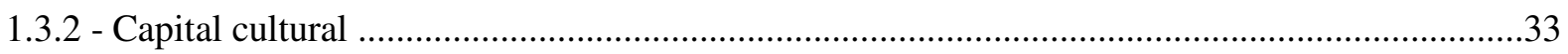

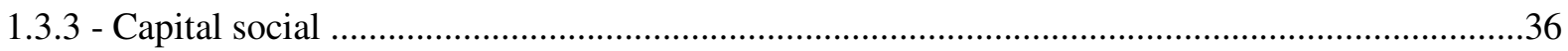

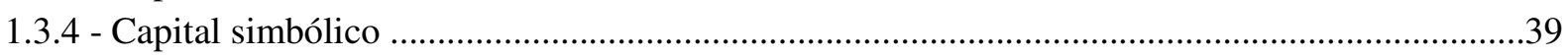

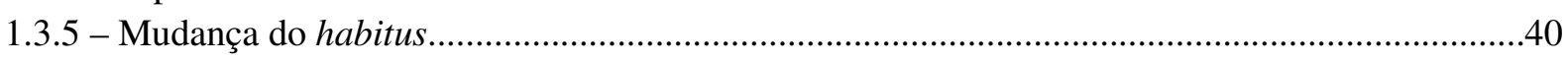

1.4 - As relações das práticas socializadoras escolares e as das famílias populares ..............................42

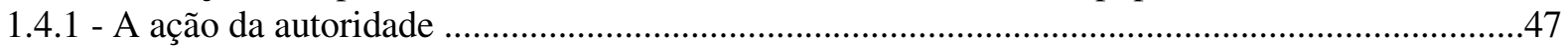

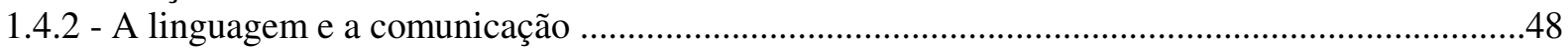

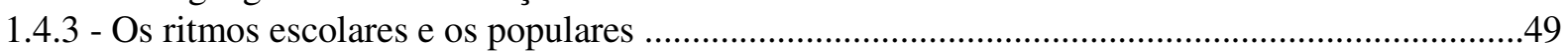

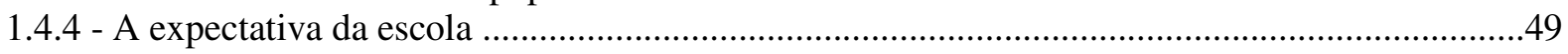

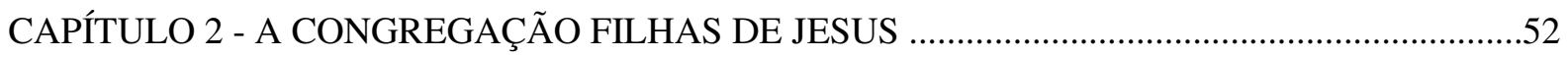

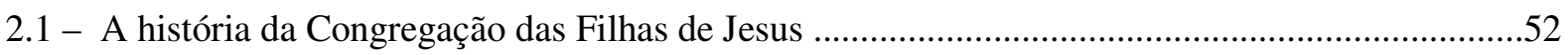

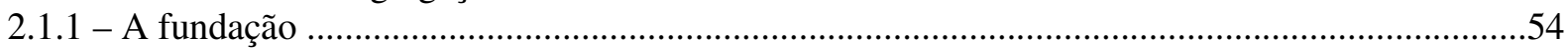

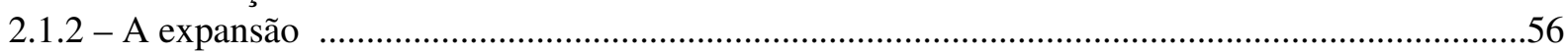

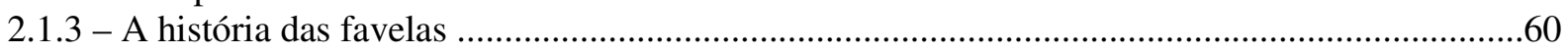

CAPÍTULO 3: A CIVILIZAÇÃO ESCOLAR E AS CAMADAS POPULARES ...............................63

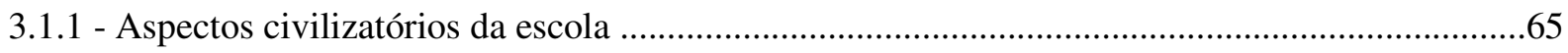

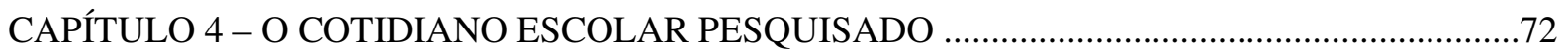

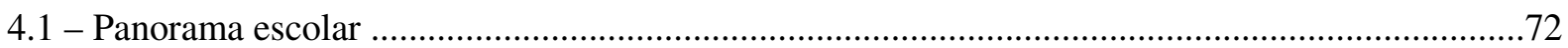

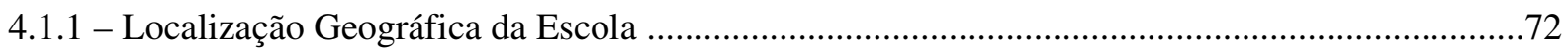

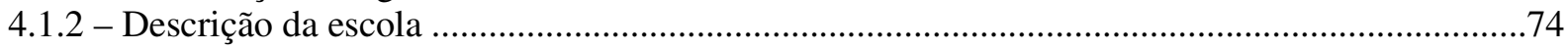

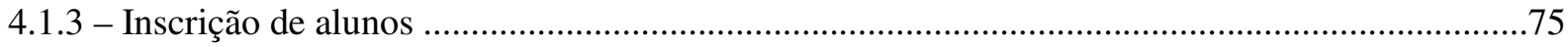

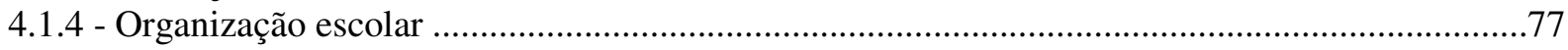

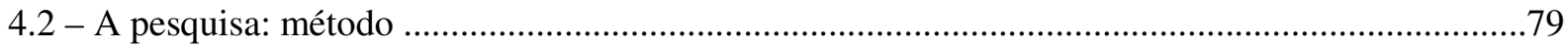

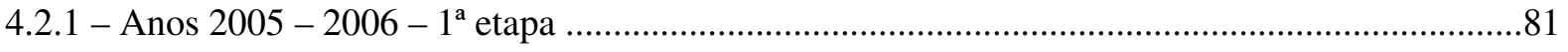

4.2.1.1 - ano 2005 - Observação e questionários aplicados aos diferentes atores da escola: alunos,

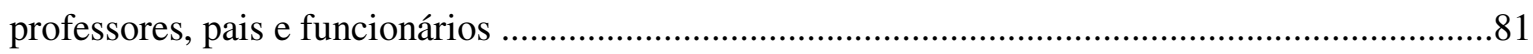

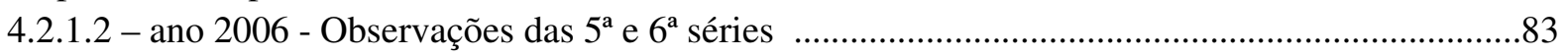

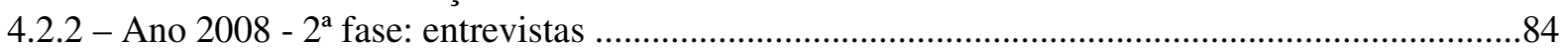


4.2.2.1 - Entrevistas com os professores:

4.2.2.2 - Quatro estudos de casos - 2008

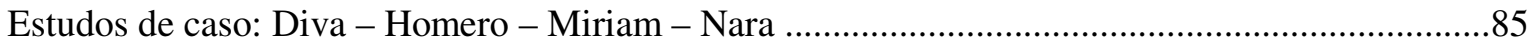

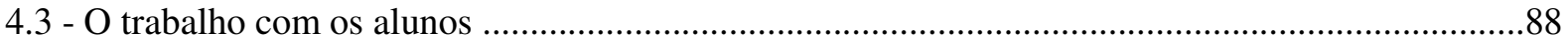

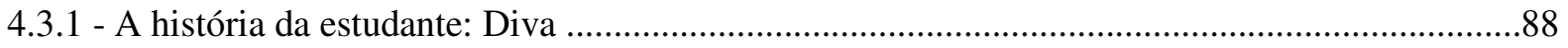

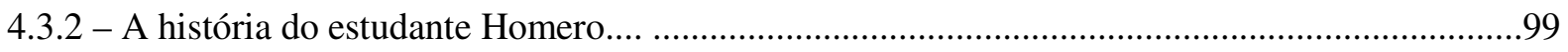

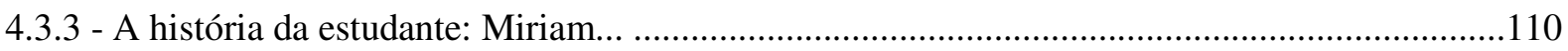

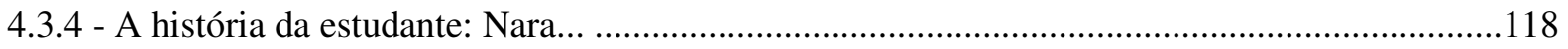

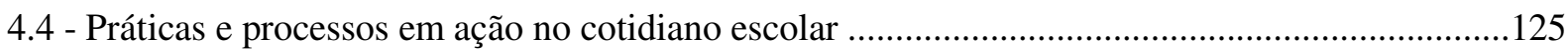

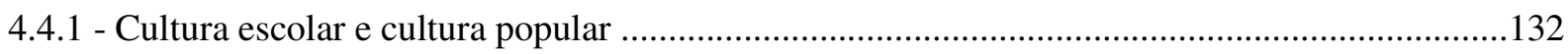

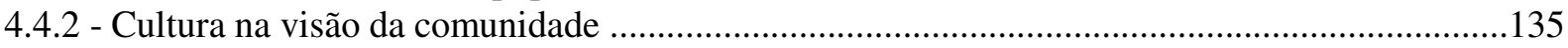

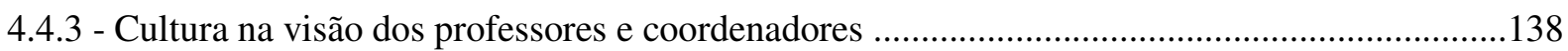

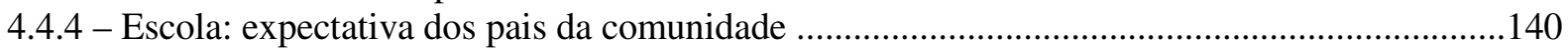

4.4.5 - A visão da comunidade do ponto de vista dos professores e coordenadores ..........................144

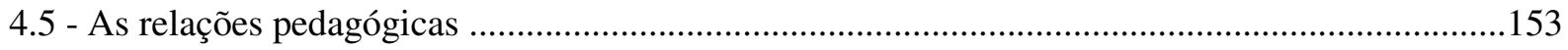

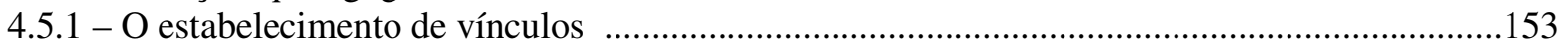

4.6 - Formas de ensinar: estratégias e recursos pedagógicos ...............................................................157

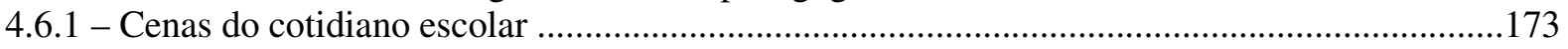

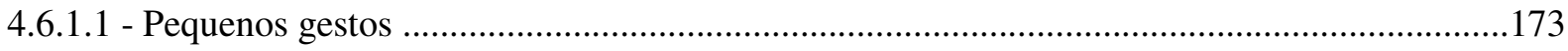

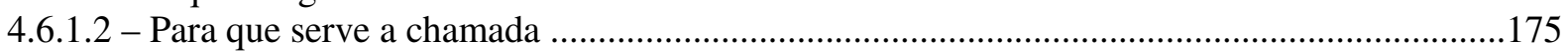

4.6.1.3 - A entrada e a saída da aula, do semestre, do ano ..............................................................176

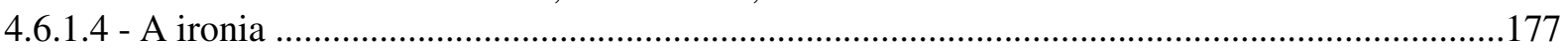

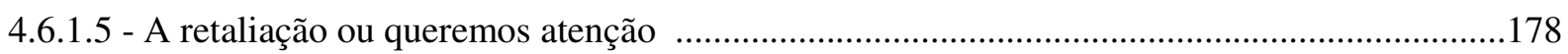

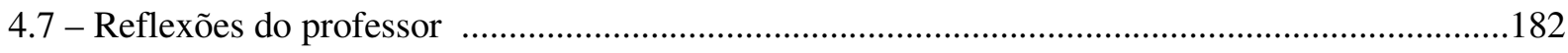

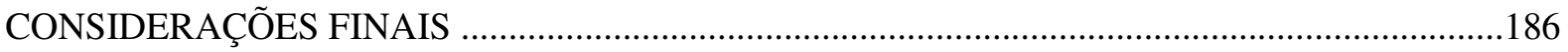

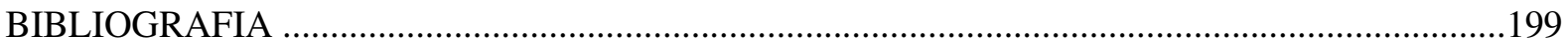




\section{LISTA DE ILUSTRAÇÕES:}

Figura 1 Localização da escola em relação aos bairros (Fonte: Google Dados Cartográficos 2009 - Maps)

Figura 2 A escola no contexto das favelas do Vidigal e da Chácara do céu, a partir de satélite (Fonte: Google Earth)

LISTA DE TABELAS

$\begin{array}{lll}\text { Tabela } 1 \quad \text { Cota escolar em } 2007 & 77\end{array}$

Tabela $2 \quad$ Turmas e idades da Educacão Infantil em $2008 \quad 78$

Tabela 3 Turmas e idades do Ensino Fundamental em $2008 \quad 78$

Tabela 4 Turmas e idades de $5^{\mathrm{a}}$ a $8^{\mathrm{a}}$ séries do Ensino Fundamental $2008 \quad 78$

Tabela $5 \quad \mathrm{~N}^{\mathrm{o}}$ de alunos por idade, de $5^{\mathrm{a}}$ a $8^{\mathrm{a}}$ série do Ensino Fundamental $2008 \quad 79$

Tabela $6 \quad$ Alunos e data de admissão $-5^{\text {a }}$ série do Ensino Fundamental $2006 \quad 83$

Tabela $7 \quad$ Alunos e data de admissão $-6^{\text {a }}$ série do Ensino Fundamental $2006 \quad 83$

Tabela $8 \quad$ Caracterização dos estudantes dos estudos de caso $\quad 86$

\section{ANEXO:}

Relação dos Documentos lidos para a confecção da história da Madre Cândida, não citados diretamente na tese 


\section{INTRODUÇÃO}

Vinte anos se passaram desde que Maria Helena Souza Patto (1990; 1999) lançou o desafio de refletirmos sobre a educação no Brasil, trazendo à tona a produção do fracasso escolar. Ela permaneceu dois anos em uma escola pública de primeiro grau onde desvendou as entranhas da produção das dificuldades de escolarização das crianças das classes populares.

Demonstrou que, de um lado, os alunos são vistos através da lente do preconceito étnico e social, infiltrado na cultura brasileira; de outro lado, apontou para a precariedade de algumas escolas, que não podem se considerar dignas de se intitular como instituição de ensino, situação agravada pela presença de um quadro de professores mal preparados e desrespeitados pela política educacional, em que projetos e reformas são concebidos e planejados por órgãos centrais de planejamento e de supervisão que reduzem os professores a meros executores. Estes são tratados como se fossem os menos capazes na cadeia de competências e o ensino torna-se uma verdadeira linha de montagem.

Os estudos de Souza Patto (1997) acerca da aprendizagem das camadas populares questionam a idéia de privação cultural dos mais pobres da população brasileira. A autora indaga-se sobre até que ponto as questões envolvidas na dificuldade de escolarização do segmento mais empobrecido das classes sociais estariam sendo contempladas pela teoria da carência cultural, "na qual a pobreza comparece como fato social naturalizado, a cultura popular como pobre de estímulos necessários ao desenvolvimento psíquico e a criança pobre como portadora de deficiências de toda ordem" (PATTO, 1997:81).

Apesar de decorridos vinte anos desde que Maria Helena Patto deu início à busca de novos rumos para a questão da produção do fracasso escolar, ainda causa impacto saber que, segundo os dados da $\mathrm{UNESCO}^{1}$ divulgados em 2006, o índice da taxa de repetência de primeira a quarta série no Brasil era de $21 \%$ de reprovação (a pesquisa usa como base o ano de 2002), o que reflete as condições insatisfatórias de ensino e de aprendizagem da escola pública brasileira.

Em 2007, o sistema educacional brasileiro estabeleceu a ampliação do ensino fundamental, de oito para nove anos, considerada uma medida benéfica por colocar o estudante mais cedo na escola, aos seis anos, com o objetivo de promover a aprendizagem e

\footnotetext{
${ }^{1}$ Organização das Nações Unidas para a Educação, a Ciência e a Cultura.
} 
tentar reverter as dificuldades enfrentadas na escolarização das classes populares. Para tanto, criou-se um Fundo Nacional da Educação Básica - Fundeb ${ }^{2}$.

Mas, afinal, o que se passa com as crianças das camadas populares em face dos conteúdos escolares que lhes são apresentados, ou mesmo, diante de toda a cultura escolar, que resulta em tamanho abismo entre o ensino promovido pela escola e o seu aproveitamento pela clientela?

Neste trabalho, sustentamos a idéia de que os estabelecimentos particulares podem e devem contribuir para subsidiar saberes educacionais que colaborem para a melhoria da escola pública. Embora existam boas experiências em educação, tanto nos estabelecimentos públicos, como nos privados, o fato é que há um hiato nas formas de colaboração entre essas duas instâncias, que, por motivos históricos foram se distanciando cada vez mais. Parte-se do pressuposto de que a experiência nas escolas públicas é alheia aos esforços que se fazem presentes nas escolas particulares e vice-versa. Ou seja, que as experiências realizadas nas escolas particulares não seriam adequadas ou até mesmo praticáveis, pois estariam distantes da realidade da escola pública. São suposições subjacentes às práticas pedagógicas, baseadas mais em pré-conceitos, do que em experiências efetivas de intercâmbio.

Nossa intenção no presente trabalho foi justamente explorar quais os desafios que se colocam para uma experiência em escola particular quando esta se propõe a atender uma clientela oriunda das classes populares, que, no caso brasileiro, se encontra mais comumente presente nas escolas públicas.

Tomamos como base para a nossa investigação uma escola que não é pública, com um perfil confessional filantrópico, que estivera voltada para as classes médias, mas que decide dedicar o ensino à população do morro, mais especificamente às crianças de duas favelas da cidade do Rio de Janeiro - o Vidigal e a Chácara do Céu. A instituição, a partir de então, abre-se para a cultura do outro e aceita ser interpelada por outros sentidos, na tentativa de

\footnotetext{
${ }^{2}$ Fundo de Manutenção e Desenvolvimento da Educação Básica e de Valorização dos Profissionais da Educação. Seus fundos destinam-se à manutenção e ao desenvolvimento da educação básica pública e à valorização dos trabalhadores em educação, incluindo uma remuneração condigna, conforme está disposto na Lei 11.494/2007. Esta lei busca ampliar a ação do fundo contábil em vigor, denominado FUNDEF (Fundo Nacional de Manutenção e Desenvolvimento da Educação Fundamental e Valorização do Magistério), que hoje financia grande parte do ensino fundamental regular, para uma cobertura ampliada que absorva toda a educação básica (infantil, fundamental e média).
} 
ampliar o acesso à educação, oferecendo uma proposta inovadora para atender as classes populares com o mesmo corpo docente que ensinava os alunos de classe média.

O problema do presente trabalho consistiu em saber como essa escola trabalha com as crianças destas comunidades e quais são os ajustes e adequações curriculares efetuados em seu projeto pedagógico para encaminhar adequadamente o novo desafio de criar estratégias de ensino compatíveis com uma clientela diferente daquela à qual estavam acostumados e com novas demandas e necessidades.

Pretendemos com esta pesquisa trazer para domínio público essa inovação que ressignificou o espaço escolar para as camadas populares. Nosso intuito é trazer contribuições para a escola pública, como forma de pensar em experiências inovadoras como alternativa para a superação das dificuldades de aprendizagem do corpo discente com base na transformação da experiência escolar.

Para isso, estudamos a construção desse novo projeto educacional e o impacto que teve a mudança da clientela nas relações entre professores e alunos, as aproximações e distâncias entre a cultura escolar e a cultura popular no cotidiano escolar (estabelecimento de limites, regras e horários), nas formas de ensinar (estratégias e recursos pedagógicos), e nos conteúdos propostos nas disciplinas das $5^{\text {as }}$ e $6^{\text {as }}$ séries dessa instituição de ensino particular de tipo confessional, a partir do redirecionamento do seu projeto pedagógico para atender as populações faveladas da Chácara do Céu e do Vidigal.

Considerando essa realidade escolar e a opção que a escola fez de atender as crianças da favela, até que ponto o projeto pedagógico implementado efetivamente conseguiu adaptarse às novas condições? Qual imagem os professores fazem dos seus alunos? Quais expectativas a própria escola estabelece em relação ao trabalho em sala de aula? Seriam mantidos métodos e conteúdos? Como isso se expressaria nos resultados escolares? Estas seriam as questões principais da presente investigação.

Nos estudos que vêm sendo veiculados pela mídia e pelas diversas revistas especializadas em Educação, há contribuições de diferentes estratégias sócio-educativas na tentativa de minimizar o impacto da enorme diferença de classes sobre o tecido social brasileiro.

Os resultados das pesquisas e estudos de Maria Helena Souza Patto, Pierre Bourdieu e François Dubet, entre vários outros, sobre a escola pública demonstram como o fracasso 
escolar é tecido. Gomes (in: PATTO, 1999) resume "alunos comuns são estigmatizados, $a$ priori, por algumas marcas derivadas de sua herança étnica e/ou por suas condições sociais e culturais de vida. A partir disso, o seu destino escolar passa a ser traçado" (Gomes, IN: PATTO, 1999:IX - grifo da autora) ${ }^{3}$. Já os professores de escolas privadas partem do pressuposto de que seus estudantes têm mais chances de sucesso na aprendizagem por estarem inseridos desde seu nascimento na "cultura erudita", em um meio cuja cultura é semelhante à norma culta veiculada pela escola.

Tomaremos essas reflexões como norteadoras do trajeto de nossa pesquisa para analisar a "opção pelos pobres" feita pela referida instituição religiosa, que nos chamou a atenção pelo fato de acenar com a possibilidade de que alguma atuação transformadora fosse possível no sentido de atender a uma população desfavorecida dos pontos de vista social e econômico, partindo do pressuposto de que uma proposta inovadora teria condições de oferecer um ensino de qualidade e permitir a essas crianças um campo para outras identificações e novas aprendizagens.

Atribuímos essa decisão a uma postura pedagógica que recusou a naturalização das desigualdades econômicas e assumiu um compromisso social e político com as camadas populares. Trata-se do projeto do Colégio Stella Maris, que optou pela formação de alunos de baixa renda, como expressão de uma espécie de "reinvenção do humano", no sentido sustentado por Bloom. A esse respeito, o autor ressalta: "Shakespeare pensava com mais abrangência e originalidade do que qualquer outro autor (...) e inventou o humano, o que hoje entendemos por humano (...) a partir da criação de novas formas de consciência" (BLOOM, 2000:1).

Ao nos aproximarmos da escola, percebemos que nosso objeto envolvia uma temática de grande complexidade, uma vez que se tratava de uma instituição religiosa, submetida à Igreja Católica, ao mesmo tempo em que se encontrava inserida no sistema educacional brasileiro. E, a partir do momento em que fez a opção de atender as camadas populares dos habitantes do município do Rio de Janeiro, moradores da zona sul, deparou-se com uma população que, apesar de pobre, vive sob a pressão do apelo consumista, dividida entre o trabalho precoce, a freqüência à escola e a tentação da ida à praia ou ao comércio mais próximo.

${ }^{3}$ GOMES, Jerusa V. IN: PATTO, M. H. S. A produção do fracasso escolar: histórias de submissão e rebeldia. São Paulo: Casa do Psicólogo, 1999, prefácio da $2^{\mathrm{a}}$ ed. de Jerusa Vieira Gomes. 
A literatura pedagógica hoje centrada sobre o que se tem nomeado de cultura escolar compreende que o ritual da própria organização interna a cada escola configura um feixe de rotinas, usos, costumes, saberes e valores que não apenas fazem parte da instituição, mas, sobretudo, "fazem" a instituição. Perscrutar esse universo cultural específico da escola requer um olhar atento para o que se passa no dia-a-dia da escola. De acordo com essa perspectiva, a cultura escolar se processa mediante códigos de conduta e saberes que perpassam a vida cotidiana da instituição. Tal movimento consolida historicamente formas de ser da escola. Compreender tais formas requer do investigador uma atenção mais detida sobre aquilo que se passa em sala de aula, o que acontece nos corredores da escola, as constatações da equipe administrativa, o discurso e comportamento dos professores, os depoimentos dos pais dos alunos, as manifestações juvenis mediante as quais os alunos registram e manifestam sua percepção da vida escolar.

A propósito da realidade da escola francesa, Dubet (2004) também levantou questões sobre em que medida o sistema público de ensino, ao preocupar-se com a igualdade de condições para todos os seus alunos, possibilitava de fato maior justiça social. Dubet acredita na possibilidade de construção de uma escola justa, isto é, preocupada com a questão da diversidade dos seus alunos. Para o autor, o desafio da Educação será encontrar alternativas de ação para lidar com essa situação escolar. Ele coloca em questão a escola meritocrática, que se atém aos que apresentam melhores resultados. Considera não ser suficiente o critério meritocrático para diminuir o impacto das desigualdades sociais, pois a escola deveria garantir a todos os seus alunos um mínimo comum de conhecimentos e competências, em busca desse ideal de igualdade, preocupando-se principalmente com a integração social dos alunos na sociedade. Por fim, que poderia permitir a cada aluno desenvolver seus talentos específicos, independentemente do seu desempenho escolar. Dubet fala dos diversos caminhos possíveis, sem que haja uma única resposta, para mostrar a complexidade do tema, demonstrando os limites de cada um deles. O mérito não assegura a diminuição das desigualdades sociais e a integração social pode efetivamente reforçar o destino social dos alunos; a exigência de um mínimo comum de conhecimentos pode servir para limitar a expressão de aptidões diferenciadas. Conclui que esses princípios poderiam servir de orientação para a instituição escolar, que deveria estar atenta e consciente de que, na tentativa de lidar com a desigualdade social dos seus alunos, priorizando o mérito, poderia estar camuflando os problemas ao invés de enfrentá-los propriamente. 
A complexidade dessa problemática suscita várias questões, pois a escola lida com alunos social, e individualmente desiguais.

Para aprofundarmos a temática desta pesquisa, buscaremos ainda interlocução com estudiosos de questões culturais, curriculares e escolares, dentre os quais citamos o educador brasileiro Paulo Freire, por suas idéias acerca da transformação da educação no sentido de uma ampla democratização, norteando-se por princípios que visam à justiça social; o professor Jean-Claude Forquin, doutor em Letras e Ciências Humanas, pelo estudo aprofundado que fez a respeito das relações entre a cultura erudita e a cultura popular no contexto de elaboração do currículo escolar; o antropólogo e sociólogo francês Pierre Bourdieu, crítico das formas institucionais de dominação e de mascaramento da realidade social de dominação, e o professor François Dubet, que entende a escola não apenas como reprodutora dos saberes existentes na sociedade, mas como uma cultura cujo sistema complexo é resultado de múltiplas interações entre professor, aluno e conhecimento em uma dada instituição, situada em uma determinada sociedade. Este aporte teórico se constituirá em um corpo de conhecimentos fundamental para nossas análises e conclusões acerca do processo sócio-cultural envolvido nas opções desta instituição.

Uma indagação que fazemos é de como tratar o impacto que a diversidade cultural encontrada, diante da nova opção da escola, teve sobre os professores considerando que estes se encontram divididos entre a imagem que tinham do aluno, presa à de sua antiga clientela, que era da classe média, e a do novo aluno, agora das camadas populares. Essa questão orientou o primeiro capítulo, em que estudamos o que se entende por cultura e camadas populares, situando dessa maneira seus personagens, principais atores e receptores dessa opção inovadora em educação.

Considerando essenciais as ponderações acima levantadas, pareceu-nos necessário, para compreender o processo de mudança do projeto pedagógico da referida escola, iniciar a discussão com o conceito sobre cultura do ponto de vista sócio-histórico, por meio dos estudos dos sociólogos franceses Pierre Bourdieu e François Dubet. Tal perspectiva favorece uma reflexão sobre o lugar social ocupado pelas instituições escolares na produção de rituais e de formas de lidar com o conhecimento, mas que também supõem maneiras de se comportar socialmente no mundo.

A segunda pergunta que emergiu desse relato foi o motivo e o momento em que tal proposta foi posta em prática. Para tanto, houve a necessidade de conhecer o histórico dessa 
instituição, assim como da congregação religiosa que a sustentava, para obtermos melhor compreensão dos fatos observados. Esse histórico é apresentado no segundo capítulo, que se inicia com as origens dessa instituição religiosa e o contexto espanhol em que essa história teve início. Sentimos que havia a necessidade também de lançar um olhar sobre a história das favelas no Rio de Janeiro e, dentro dela, analisar a evolução das comunidades (nome atual dado à população que habita as favelas) do Vidigal e da Chácara do Céu.

O terceiro capítulo é dedicado ao estudo do lugar que a escola ocupa na sociedade, com a contribuição de Forquin (1993) no seu estudo criterioso sobre cultura escolar que repensa a importância da escola universal e obrigatória junto com as questões levantadas por Bourdieu e Dubet sobre a produção do fracasso escolar.

No quarto capítulo, nos dedicamos ao cotidiano escolar, orientados por um modelo de pesquisa qualitativa, com ênfase no estudo de caso, para analisarmos a dinâmica da instituição escolar. Estudamos o impacto que teve a mudança de clientela na alteração de relações pedagógicas entre professores e alunos e as aproximações e distâncias, familiaridades e tensões, entre a cultura escolar e as culturas populares. Todo esse cenário certamente se constitui como elemento fundamental para a construção desse novo projeto educacional. A observação, a análise documental e as entrevistas têm um papel importante nesse processo por serem os instrumentos por excelência de pesquisa sobre as condições de efetivação do conhecimento escolar em uma dada instituição escolar e religiosa que esteve voltada até recentemente para a formação de uma elite (dos pontos de vista cultural e econômico) e que, a partir de uma conjuntura específica, optou pela educação da população de baixa renda. Pretendemos averiguar, no cotidiano institucional, como esse projeto da escola se materializa nas situações cotidianas e na organização curricular. O que propomos aqui, sobretudo, é a elucidação de um saber, envolvido na ação pedagógica assumida por uma instituição escolar nas $5^{\text {as }}$ e $6^{\text {as }}$ séries do Ensino Fundamental, por nós escolhidas na tentativa de observar os impasses e desafios experimentados em sala de aula para a sua efetivação.

Escolhemos essas duas séries, movidos pelo interesse e desafio em conhecer a opinião dos alunos, de seus professores, pais e funcionários, pois, segundo a Direção, houve maior dificuldade para a implantação do projeto nessas turmas com necessidade de orientações e intervenções pontuais não só em relação aos alunos, como também com os professores. Duas são as hipóteses da direção: os alunos virem de outras experiências escolares da escola 
pública, e os professores, por serem os mais antigos, terem tido experiência com outra camada social - classes média e média alta.

Diante da complexidade da situação, nosso pensamento começou a circular em torno da questão suscitada pelo verso de Mario Quintana: "Democracia? É dar, a todos, o mesmo ponto de partida. Quanto ao ponto de chegada, isso depende de cada um". Essa idéia reflete parte da nossa pesquisa acerca do papel da educação e da escola. Foi no sentido de investigar em que medida o "ponto de chegada vai depender realmente de cada um" que encaminhamos este trabalho, refletindo sobre a influência do meio social entre os estudantes, em que alguns têm maior proximidade com a cultura "erudita", pelas práticas culturais ou lingüísticas de seu meio familiar que lhes oferece maiores chances de obter o sucesso escolar. Coube, então, à escola a tarefa árdua e instigante de oferecer igualdade de oportunidades para garantir um mínimo de igualdade social, uma vez que, mesmo com o advento do regime democrático desde a década de 80, não conseguiu garantir efetivamente a cidadania a todos, nem tampouco oferecer melhores condições de vida e de escolarização ao conjunto da população brasileira.

Nossa introdução termina com as palavras de Bourdieu, em seu artigo “A escola conservadora", publicado originalmente em 1966:

[...] para que sejam favorecidos os mais favorecidos e desfavorecidos os mais desfavorecidos, é necessário e suficiente que a escola ignore, no âmbito dos conteúdos do ensino que transmite, dos métodos e técnicas e dos critérios de avaliação, as desigualdades culturais entre as crianças das diferentes classes sociais (BOURDIEU, 2005:53).

Questão que norteou nossas preocupações na presente investigação. 


\title{
Capítulo 1 - Uma abordagem histórico-conceitual de cultura
}

\begin{abstract}
"Quantas vezes, na escola, avaliamos as crianças, principalmente as das classes populares, pelas nossas formas de dizer e fazer e, com isso, desconsideramos as suas próprias formas?"
\end{abstract}

Carmen Sanches Sampaio (2003:37)

Considerando fundamental a afirmação de Gaarder (1997:29), segundo a qual, “a resposta é sempre um trecho do caminho que está atrás de você" e que só "uma pergunta pode apontar o caminho para frente", tomamos como ponto de partida uma série de questionamentos a respeito da relação entre a escola e as camadas populares que foram suscitados por esta pesquisa realizada no referido colégio. Notamos que esta escolha, para ser devidamente assumida, necessita ser diariamente construída e reconstruída.

Utilizaremos o termo camadas populares conforme a definição dada por Madga Soares, em seu livro Linguagem e escola:

\begin{abstract}
"A palavra camada, quando empregada para designar grupos sociais, significa um conjunto particular de indivíduos que não constitui um elemento estrutural independente da sociedade, mas é modelado por circunstâncias sociais e econômicas. Os indivíduos ou grupos de indivíduos que constituem uma camada tendem para uma ou outra das duas classes sociais em oposição (classes dominantes ou classes dominadas), e, dentro de cada uma, distribuem-se em diferentes classes, ou frações de classe. Assim, a expressão camadas populares designa grupos sociais que, pertencentes às classes dominadas, identificam-se por uma característica comum, a de constituírem um conjunto de grupos polarizados em oposição àqueles que detêm o monopólio do poder e do controle econômico e social“" (SOARES, 1986:80-81).
\end{abstract}

Também o autor Bernard Charlot, em seu livro Da relação com o saber - elementos para uma teoria, contribui para uma melhor apropriação do termo "camadas populares", uma vez que aponta também para possibilidades de transformação das relações de força entre as classes sociais, definindo-as como:

\footnotetext{
“categorias sociais populares - para designar e definir essas famílias ditas 'populares' e 'desfavorecidas'. Considerarei aqui como 'populares' aquelas famílias que ocupam uma 'posição dominada' na sociedade, vivem em situações de pobreza ou precariedade, produzem uma configuração teórica e prática do mundo que traduz ao mesmo tempo sua posição dominada e os meios implementados para viver ou sobreviver nessa posição e, às vezes, transformar as relações de força" (CHARLOT, 2000:11).
}

Esta escola pensa seu ofício, ou seja, enquanto "colégio educador" a partir do par experiência e sentido como explicita o filósofo em Educação, Jorge Larrosa Bondia, uma vez que a escola alia o que ela sabe fazer ao que lhe dá sentido e mostra em sua ação educativa que pensar "é sobretudo dar sentido ao que somos e ao que acontece". (LARROSA 2001:1). 
As questões que nos propomos a investigar relacionam-se com os possíveis embates gerados pelo encontro da noção de cultura da escola e a trazida por essa nova população que se matriculou na escola. Qual é a noção de cultura veiculada pela escola? A das boas maneiras? A do cultivo do espírito? A opção pelas camadas populares feita por essa escola estaria a serviço da colonização da população "dita inculta" ou "não civilizada"? Ou mais especificamente a escola acredita ser o instrumento transmissor da CULTURA em letra maiúscula no sentido atribuído por Bénéton (1975) à "civilização proselitísta" que, segundo uma perspectiva eurocêntrica, corresponderia à "forma mais elevada de evolução social"?

Valle e Queiroz ${ }^{6}$ (1979;1988), organizadores do "Simpósio sobre a cultura do povo" ousaram fazer a seguinte pergunta: haveria, no povo, uma "cultura-apesar-de-tudo"? (...) e como se expressaria esta cultura do povo, em especial no caso das grandes metrópoles, onde o homem do povo é engolido diariamente, exercendo (quando exerce) uma função produtorproduzido, sem condições de usufruir da riqueza que ele ajudou a criar, muitas vezes sem raízes na cidade, por ter deixado para trás sua cidade natal?

Macedo $^{7}(1979 ; 1988)$ opondo-se à concepção de "civilização proselitísta", afirma que a "análise do problema da cultura parte do reconhecimento de que não existe atividade humana desvinculada da construção de significados que passam a dar sentido à existência. Em sua vida social, os homens produzem formas de pensar essa vida e sua inserção nela. Analisar a cultura envolve a consideração do produto da atividade humana, mas também do processo dessa produção, do modo como esse produto é socialmente elaborado" (Macedo, in: VALLE \& QUEIRÓZ, 1979:35).

Para Macedo, "cumpre deixar claro que a noção de cultura, em ciência social, nada tem a ver com as idéias de senso comum em que a cultura se identifica com o saber, com o erudito e, até mesmo, com refinamento - e aí se contrapõe à incultura, à ignorância, à rudeza.

\footnotetext{
${ }^{4}$ Bénéton (1975) sublinha que dentro desse movimento universal, mas não uniforme da civilização, havia certo número de sociedades mais avançadas como a Europa, que se atribuíram e encarnaram o papel histórico de serem os representantes "d'A civilização", entendida como a forma mais elevada da evolução social. Essa identificação fez com que surgisse o emprego da oposição entre povos civilizados versus povos bárbaros ou selvagens. Esse etnocentrismo contribuiu para um novo sentido da palavra civilização que passou a ser considerada um valor, uma qualidade que refletiu a pretensão do Ocidente de deter o monopólio do uso da palavra civilização e conduziu a idéia de uma civilização proselitista, isto é, com a missão de recrutar adeptos por considerarem os povos primitivos como selvagens e, portanto, em um estágio inferior de civilização. Desse modo justificaram a colonização desses povos. Os valores próprios das sociedades colonizadas foram, na maioria das vezes, ignorados e o conceito de civilização apareceu como um dos elementos essenciais da ideologia colonial.

${ }^{5}$ Coordenador Pós-Graduação em Ciências de religião da PUC/SP - 1988

${ }^{6}$ Diretor do Instituto de Estudos Especiais da PUC/SP - 1988

${ }^{7}$ Professora do Depto de Antropologia - PUC-SP.
} 
A cultura consiste num conjunto global de modos de fazer, ser, interagir e representar que, produzidos socialmente, envolvem simbolização e, por sua vez, definem o modo pelo qual a vida social se desenvolve" (Macedo in: VALLE \& QUEIRÓZ, 1979:35, nota 1).

Ponderando sobre o acerto desta última concepção de cultura, buscamos uma efetiva compreensão do conceito de cultura veiculado pelo colégio Stella Maris, enquanto tal, pelos professores, Direção e pais de alunos.

Esta instituição escolar, ao se aproximar das camadas populares respeitando a cultura popular, nos levou a investigar os sentidos da expressão "cultura popular". Buscamos averiguar seu significado em um centro urbano como a cidade do Rio de Janeiro, cujas instituições privadas do ensino estiveram quase sempre mais comprometidas com os interesses dos grupos dominantes do que com os valores, crenças, sentimentos e atitudes das camadas desfavorecidas da população.

Nessa pesquisa, utilizaremos o conceito de classe dominante no sentido utilizado por Bourdieu (1989; 2007), de uma população detentora dessa realidade tangível que se chama poder:

[...] entendendo por tal as relações de forças entre as posições sociais que garantem aos seus ocupantes um quantum suficiente de força social - ou de capital - de modo que estes tenham a possibilidade de entrar nas lutas pelo monopólio do poder, entre as quais possuem uma dimensão capital as que têm por finalidade a definição da forma legítima do poder (BOURDIEU, 2007:28-29).

Para a compreensão das desigualdades de desempenho escolar entre os diferentes grupos sociais, estaremos utilizando a idéia de capital cultural como o "divisor de águas" no confronto $^{8}$ entre, de um lado, as classes populares que ocupam uma posição dominada na sociedade capitalista, e que, segundo a teoria de Bourdieu, detêm um menor patrimônio em quaisquer dos capitais, seja econômico, cultural, social, escolar, etc.; e de outro, as classes dominantes constituídas pelos que têm um domínio maior da língua culta e as informações sobre o mundo escolar, bem como são detentores dos demais capitais.

\footnotetext{
${ }^{8}$ A noção de confronto nas relações não quer dizer que estas se dêem necessariamente com conflito, no entanto indica a existência de uma tensão constitutiva das relações, mas que podem ser solucionadas por ajustes recíprocos, como esclareceu Thin (2006:215).
} 


\section{1 - Cultura: conceito sociológico}

A história do conceito de cultura coloca em foco a importância da função ideológica das 'grandes' palavras (mots clefs) e aponta que o problema do vocabulário não deve ser considerado de competência exclusiva dos lingüistas, mas deve ser tema de estudo para todos os que se dedicam ao campo das ciências humanas.

Para o teórico da educação Bantock (1971), a palavra cultura é usada em dois sentidos. Por um lado, os antropólogos a utilizam para designar o esquema de vida de uma sociedade, ou seja, as maneiras com que os homens cooperam entre si, e/ou entram em conflito, sua organização social e política, suas cerimônias, mitos e rituais, os métodos empregados para criar e educar seus filhos; tudo isso Bantock aponta como manifestação da cultura, superficial ou profunda, de acordo com cada caso. De tal maneira que esta palavra não implica juízos de valor, pois tudo revela a cultura e não somente uma pequena soma de detalhes selecionados. O outro uso da palavra cultura implica um alto grau de seletividade. Refere-se a um conjunto específico de habilidades, maneiras de compreender e sentir, presentes nas produções científicas, artísticas e práticas. De acordo com esse modo de ver, um homem culto é um ser refinado, grande leitor e uma pessoa informada acerca do acúmulo de conhecimento produzido pelas ciências. Só quem teve um longo período de educação, um extenso processo de construção de conhecimento se torna um homem erudito. É desse ponto de vista que Bantock concebe duas culturas: a erudita e a popular.

Em uma direção semelhante, segue a psicóloga social Bosi $(1979 ; 1988)$ ao falar da existência de uma cultura vivida e uma cultura a que os homens aspiram ter acesso, que se vê atravessada, na maioria das vezes, por uma concepção ideológica de cultura. Segundo a autora, representação e valores se agrupam em torno do eixo: "adquirir cultura". E ela indaga: "Seria a cultura um elemento de consumo? Ou é uma oposição e uma superação do natural, um desabrochar da pessoa na vida social?" (BOSI, E. 1988:28).

Philippe Bénéton (1975) realizou uma pesquisa minuciosa sobre a história do termo cultura a partir de dicionários e da literatura de diversas épocas trazendo dados desde o século XIII até a contemporaneidade. De acordo com seus estudos, a palavra cultura é um termo antigo, vindo do latim, que nasceu na língua francesa no final do século XIII. Na época medieval, era utilizada para designar o estado de uma terra cultivada e também significava 
culto religioso. Essas duas definições tiveram rumos bem diferentes, tanto é que a segunda caiu em desuso vindo a desaparecer por completo no século XVI, enquanto que o primeiro sentido evoluiu e passou a determinar não mais o estado de uma terra cultivada, mas sim o ato do cultivo da terra, encontrando seu sentido tal qual era utilizado na língua latina.

Bénéton (1975) sustenta a esse respeito, que do sentido original, o termo cultura conservou-o como metáfora, vindo a designar figurativamente a cultura de espírito, embora esse significado tenha sido ignorado pelos lingüistas até o final do século XVII. Em 1680, o termo vem designado no dicionário Richelet no seu sentido figurado onde a palavra cultura é ligada ao cultivo das artes e do espírito. Foi em 1691, assinala Bénéton, que pela primeira vez a palavra cultura passou a ser utilizada sem complemento, designando de uma maneira geral a formação do espírito. Em suas palavras: "Le sens figuré a acquis son autonomie" (Bénéton, 1975:26) ${ }^{9}$. Ele sublinha que esse processo de passagem do sentido próprio para o termo figurado, esse jogo metafórico que acontece quando um termo substitui outro em vista de uma relação de semelhança entre os elementos que esses termos designam, é um processo comum da língua e nos informa que assim como cultura em latim e paralelamente culture em francês, também o termo inglês culture evoluiu do mesmo modo. Tanto é assim, que, por volta do século XV, seu significado na língua inglesa era de culto religioso e ação de cultivar a terra e, a partir do século seguinte, passou a significar o refinamento dos modos e maneiras, a cultura da mente, das faculdades, dos modos de ser em sociedade, usos e costumes, etc. No limiar do Iluminismo, o termo em francês e inglês mostrava um movimento corrente da língua, mas ainda não expressava as idéias da época.

Foi na segunda metade do século XVIII, continua o autor, que o conceito de cultura, já em seu sentido figurado, começou a se impor, principalmente nas publicações dos filósofos iluministas. Turgot (1727-1781), por exemplo, falou sobre a cultura das artes e Rousseau sobre a cultura das ciências, entre outros pensadores da época. Conforme nos assinala Bénéton (1975), a evolução do termo prosseguiu e, em 1798, seu sentido passou a ser encontrado não mais como instrução, estado de espírito cultivado ou da formação do espírito, mas sim como o resultado dessa instrução. Mesmo assim o termo teve um status modesto, não sendo utilizado no léxico dos filósofos e pouco utilizado entre os ideólogos da revolução francesa.

\footnotetext{
${ }^{9} \mathrm{O}$ sentido figurado conquistou sua autonomia (tradução livre)
} 
O vocabulário francês do século XVIII, continua Bénéton, dispunha de ampla gama de termos 'concorrentes' para designar com precisão o intelecto dos indivíduos ou seu resultado como lumières, instruction, éducation, enseignement, érudition, belles lettres, docte, savant, homme d'esprit, bel esprit, esprit fini, esprit fort, etc. O sentido de cultura era implícito e limitado, sempre usado no singular e representava o ideal unitário do século XVIII e sua perspectiva universalista.

\subsection{1 - Cultura, civilização e mundialização}

Trouxemos essa questão para esclarecer o que denominamos de civilização escolar, que muitos estudiosos utilizam indistintamente como sinônimo de cultura escolar. No entanto consideramos que não é exatamente a mesma coisa. Buscaremos distinguir os conceitos de cultura, civilização e mundialização ao longo do trabalho na intenção de contribuir para o debate sobre a escola como uma instância social produtora, não apenas de conhecimento, como de cultura e civilização. Nesse sentido, além de possuir um universo próprio, específico, de apropriação cultural, o ambiente escolar mobiliza de uma maneira peculiar e privilegiada as referências civilizatórias de uma determinada sociedade. Assim, a escola lida com uma vertente prescritiva, que supõe uma determinada concepção de desenvolvimento humano e uma determinada concepção de história, que tende a pressupor que o futuro será melhor que o presente; e que este, por sua vez, é melhor do que o passado. As gerações mais velhas, ao fazerem isso, conferem à instituição escolar um lugar privilegiado naquilo que Norbert Elias nomeia como "processo civilizador", segundo o qual, por meio da escola, assegurar-se-ia um "bom comportamento uniforme" (ELIAS, 1994:91), o qual, por sua vez, determinaria expectativas e referências em relação às outras pessoas. $\mathrm{O}$ processo civilizador envolve, sem dúvida, alguma relação com o poder, mediante a intensificação da "pressão que as pessoas exercem reciprocamente umas sobre as outras" (ELIAS, 1994:93). E a escola seria protagonista desse território civilizador.

Norbert Elias (1994) já se reportava ao conceito de civilização - desde os anos 30 exatamente para distingui-lo da acepção de cultura. Ele apresentava a tese de que a civilização é, no limite, uma interdependência entre as pessoas, que, como tal, estabelece elos e laços sociais, compondo uma ordem coletiva pautada por referências comuns; ou "regularidades imanentes às configurações sociais" (ELIAS, 1993:194). Para o autor, civilização supõe um dado percurso, mediante o qual são compreendidos e desenvolvidos modos de ser, tanto do 
ponto de vista do conhecimento científico e tecnológico quanto das maneiras de se comportar em relação a postulados religiosos, jurídicos e civis. A idéia de civilização, para ele, contempla inclusive as particularidades das diversas culturas específicas de nações ou regiões. De qualquer modo, destaca o autor:

[...] A moderação das emoções espontâneas, o controle dos sentimentos, a ampliação do espaço mental além do momento presente, levando em conta o passado e o futuro, o hábito de ligar os fatos em cadeias de causa e efeito - todos estes são distintos aspectos da mesma transformação da conduta, que necessariamente ocorre com a monopolização da violência física e a extensão das cadeias da ação e independência social. Ocorre uma mudança 'civilizadora' do comportamento (ELIAS, 1993:198).

Renato Ortiz (1994; 2006), em seu estudo sobre mundialização e cultura, atualiza essa discussão feita por Norbert Elias, ao partir da seguinte premissa: percebe a existência de processos globais que transcendem os grupos, as classes sociais e as nações, ou seja, a mundialização que é um fenômeno recente, "um processo ainda em construção" (ORTIZ, 2006a:15). Nesse sentido, a idéia de mundialização da cultura envolve a uniformização de usos e costumes imposta pelo processo de globalização. Isso envolve evidentemente um conjunto de valores, formas de comportamento; enfim, estilos de vida. O cenário globalizado é, todavia, algo que se formou a pouco e pouco.

Ortiz considera o advento da modernidade associado à idéia da racionalização da sociedade, em seus diversos níveis, econômico, político e cultural. No seu parecer, a modernidade é um tipo de organização social que permite o 'desencaixe' das relações sociais graças à separação do espaço e do tempo: os indivíduos, por não serem mais confinados em lugares seguros que lhes conferia estabilidade, em que os limites os separavam de acordo com as classes sociais, ou a cidade do campo, a cultura erudita da cultura popular, impedindo o deslocamento de um polo a outro. Ao invés disso, a modernidade rompe este equilíbrio e traz como princípios estruturantes a funcionalidade, a mobilidade e a racionalidade. Segundo Ortiz, a sociedade moderna pensada desta forma, "é um conjunto desterritorializado de relações sociais articuladas entre si" (ORTIZ, 2006a: 50) e esclarece que "dizer que a modernidade se desvincula de sua territorialidade significa reconhecer a existência de um padrão civilizatório distinto de sua origem (se for verdadeiro que ela é fruto do Ocidente) e pode, portanto, ser assimilada por outras culturas, distantes dos valores ocidentais" (ORTIZ, 2006a:51). Ele sublinha que admite falar em sociedades, ao invés de considerar um cenário de sociedade global, por acreditar na manutenção dos valores culturais tradicionais, que caracterizam os povos e as nações do mundo, apesar de sua inserção no panorama dado pelas 
interpenetrações sócio-econômicas e culturais, as quais marcam o processo de mundialização na grande sociedade global que hoje nos abriga.

Para Renato Ortiz, é exatamente o caráter de totalidade intrínseco ao fenômeno da mundialização que nos permite aproximá-lo da idéia de civilização. Mas Ortiz identifica uma peculiaridade no universo da mundialização, que o distancia da acepção original de civilização. Para ele, esta última estaria confinada a um espaço demarcado, estabelecido no limite de fronteiras, mais ou menos extensas. Por outro lado, a cultura mundial dos dias de hoje corresponderia a uma "civilização cuja territorialidade se globalizou" (ORTIZ, 2006a:31). Seja como for, ambos os conceitos alinham-se ao reportar-se a uma progressiva homogeneização de hábitos, de formas de agir e também de pensamentos, com a diferença que agora expandiu-se para além das fronteiras nacionais ou regionais.

BOTO (2007) recupera as teses de Elias para interpretar o tema da escolarização que progressivamente teria sido construída pela época moderna: "qual seja, seu aspecto civilizador - ou o desejo de inscrever, na formação das crianças e dos jovens, um dado modelo cultural prévio e anteriormente prescrito" (BOTO, 2007:1). Seguindo ainda os marcos conceituais e a periodização recortada por Elias $(1993 ;$ 1994), Boto reporta-se ao período da Renascença como marco inaugural de uma nova etapa da Humanidade pelo fato de ser essa a época em que se constituiu progressivamente o 'sentimento moderno de infância' a partir da distinção entre a condição de criança e a condição de adulto. Como aponta Ariès (1973, 1978), a Idade Média não trazia o sentimento da infância como acontece nos tempos modernos. Segundo as palavras de Boto, o processo civilizador renascentista:

\footnotetext{
[...] viria marcado por alguma pretensão de universalizar traços comuns constitutivos de um dado padrão cultural para postulá-lo como expressão da humanidade. Civilizado seria atributo do que se proclama valer para todos, embora servisse efetivamente para distinguir alguns. Por ser assim, é possível verificar que os próprios discursos sobre educação no Humanismo pretendiam configurar-se como empreendimentos civilizadores: aquilo que fará a diferença de classe social; ao mesmo tempo que pretende possuir validade universal (BOTO, 2007a:18-19).
}

A autora interpreta o discurso pedagógico acerca da criança e de sua educação a partir de Erasmo, Montaigne e Vives, em cujos discursos pode-se verificar a crença dos humanistas de que a trilha da civilização requereria padrões uniformes de conduta dita "bem educada". Para Boto (2007) os colégios apareceram no mundo ocidental como uma forma estruturadora desse mesmo percurso civilizador das sociedades do Ocidente, por meio da formação dada às 
novas gerações. Nas suas palavras: "O colégio forma a criança; e esta ensinará sua família. Trata-se de um inaudito modelo de ordenamento social. $\mathrm{E}$ as famílias, de fato, progressivamente, pareciam delegar mais e mais uma parcela de sua responsabilidade educativa àquela outra instituição" (BOTO, 2007a:35). A escola terá então como tarefa não somente:

[...] divulgar o conhecimento acumulado, mas recortá-lo e selecionar dos saberes aquilo que merecerá ser resguardado dos estragos do esquecimento histórico. (...) A escola veicula uma cultura que não pretende ser qualquer cultura. A escola moderna erige-se como a portadora do tônus civilizatório. Por ser assim, trata-se de pensar a circunscrição histórica que presencia o nascedouro dessa dinâmica civilizatória especificamente moderna e especificamente escolar (BOTO, 2007a:35-36).

\section{2 - As causas do fraco desempenho escolar das camadas populares}

Até meados do século XX, a escolarização era considerada fundamental na missão de oferecer igualdade de oportunidades para garantir a igualdade social a todos. Supunha-se que, por meio da escola pública, gratuita e leiga, o problema do acesso à educação seria resolvido e, assim, estaria garantida, em princípio, a igualdade de oportunidades entre todos os cidadãos em uma sociedade justa, aberta e democrática.

Na perspectiva de Patto (1990) e segundo as palavras de Mário Quintana ${ }^{10}$ (1973; 2006: 141), essa idéia traz à luz a questão da ideologia do dom, segundo a qual as causas do sucesso ou fracasso escolar deveriam ser buscadas nas características dos indivíduos, uma vez que a escola ofereceria "igualdade de oportunidades". Dom se traduziria por aptidão, inteligência, talento de cada um. O êxito dependeria das qualidades inerentes ao indivíduo desde o seu nascimento, que poderiam ser aferidas de mil maneiras: aptidões, talentos, dotes, etc. As desigualdades e diferenças individuais, assim legitimadas, é que explicariam as diferenças de rendimento escolar ${ }^{11}$.

Dessa forma, a escola se eximiria da responsabilidade pelo mau rendimento do aluno; a causa estaria na ausência de condições básicas para a aprendizagem, condições que só

\footnotetext{
10 “Democracia? É dar, a todos, o mesmo ponto de partida. Quanto ao ponto de chegada, isso depende de cada um”

${ }^{11}$ Os estudos de Patto (1990) não tratam sobre a ideologia do dom, mas analisam a questão do fracasso e do baixo desempenho escolar das camadas populares denunciando a crença generalizada da sociedade na incompetência das pessoas pobres. Ela vai além quando afirma que mesmo os pesquisadores que conseguem identificar inúmeras condições que podem explicar as altas taxas de reprovação e evasão escolar, por vezes, não conseguem se livrar desse pré-conceito e continuam a defender as teses da teoria da carência cultural.
} 
ocorreriam na presença de determinadas características indispensáveis ao bom aproveitamento daquilo que a escola oferece. Para Magda Soares (1986), a ideologia do dom, ainda hoje está muito presente na educação e internalizada nos indivíduos. Pode ser exemplificada pelo aluno que sempre se culpa pelo fracasso na escola, raramente duvidando desta, que teria como função adaptar, ajustar os alunos à sociedade, segundo suas aptidões e características individuais.

No entanto, com a ampliação do acesso a escolarização das camadas populares, evidenciou-se que as diferenças naturais não ocorriam somente entre os indivíduos, mas, sobretudo entre grupos de indivíduos e a busca de resposta para essas questões levou ao surgimento de uma outra ideologia: a ideologia da carência cultural, segundo a qual as desigualdades sociais é que seriam responsáveis pelas diferenças de rendimento dos alunos na escola; em outras palavras, são as formas de socialização da criança que permitem o seu desenvolvimento, desde a primeira infância, de características - hábitos, atitudes, conhecimentos, habilidades, interesses - que lhe dão a possibilidade de ter sucesso na escola. Soares (1986) esclarece que não se criticou a estrutura social responsável pela desigualdade social, que privilegiou as classes dominantes em relação às classes dominadas, não apenas do ponto de vista econômico, mas cultural: as diferenças entre grupos sócio e economicamente favorecidos e os desfavorecidos não são vistas como antagônicas, muito menos como o resultado de relações sociais injustamente assimétricas. Ao contrário, os partidários dessa explicação defendem uma 'superioridade' do contexto cultural das classes dominantes, em confronto com a 'pobreza cultural' do contexto em que vivem as classes dominadas (...). A explicação para o fracasso escolar dos alunos das classes dominadas estaria nas desvantagens ou déficits em conseqüência de:

\footnotetext{
[...] problemas de 'deficiência cultural', 'carência cultural' ou 'privação cultural'; o meio em que vivem seria pobre não só do ponto de vista econômico - daí a privação alimentar, a subnutrição, que teriam conseqüências sobre a capacidade de aprendizagem - mas também do ponto de vista cultural: um meio pobre em estímulos sensórios, perceptivos e sociais, em oportunidades de contato com objetos culturais e experiências variadas, pobre em situações de interação e comunicação (SOARES, 1986:12).
}

O contexto cultural do aluno seria responsável por seu fraco desempenho escolar, e seu meio social e familiar fariam dele um 'carente', ou um 'deficiente'. 
O pensamento educacional depois de muito insistir na teoria da carência cultural, nos anos setenta, com as idéias introduzidas por Bourdieu e Passeron, deu lugar a novos referenciais teóricos que vão nortear outras formas de conceber o papel da escola numa sociedade dividida em classes. Bourdieu e Passeron não discordavam da idéia de disparidade cultural, mas defendiam que a educação perdera o caráter que lhe foi atribuído de instância transformadora e democratizadora das sociedades, passando a ser vista como uma das principais instituições por meio da qual se mantêm e se legitimam os privilégios sociais, exercendo uma verdadeira "dominação cultural", cuja ação ideológica estaria a serviço da reprodução das relações de produção. Nesse sentido, a escola incorpora, veicula e principalmente privilegia estilos de pensamento e de linguagem característicos dos integrantes das classes dominantes. Desse modo, o sistema de ensino seria um instrumento a serviço da manutenção dos privilégios educacionais e profissionais dos que detêm o poder econômico e o capital cultural em uma dada sociedade.

Para Patto (1990), as idéias de Bourdieu e Passeron (1975) não foram bem compreendidas no pensamento educacional brasileiro e, segundo ela, inclusive houve distorções conceituais. Ela assinala que o conceito de dominação nem sempre foi compreendido em sua essência - isto é, como complemento cultural da exploração econômica inerente a uma sociedade de classes regida pelo capital. Dominação, segundo a autora, passou erroneamente a ser interpretada

[...] como imposição da cultura da maioria a grupos minoritários ou como imposição dos valores da classe bem sucedida à classe malsucedida no contexto urbano, por intolerância, moralismo ou inadvertência da primeira (classe bem sucedida) para com a existência de subculturas distintas da sua na sociedade inclusiva (PATTO, 1990:147).

Pelos equívocos na definição das classes antagônicas, a dominação passou a ser entendida como um desencontro cultural entre dois segmentos culturais distintos (ricos e pobres, dominantes e dominados, classe média e classe pobre) que resultava na segregação dos grupos e classes mais pobres, supostamente portadoras de padrões culturais completamente diferentes dos padrões da classe média. Essas diferenças culturais eram atribuídas às diferentes condições de vida das classes, que as levariam a posturas e valores diferentes, embora pertencentes ao mesmo contexto urbano. Esses determinantes sociais estruturais das condições diferentes de vida não são explicitados, a existência de relações de produção calcada na exploração, de interesses inconciliáveis de classes antagônicas ficava 
omitida e as pesquisas passaram a veicular uma interpretação do papel social da escola em total desacordo com o conjunto conceitual da teoria que eles inspiravam.

Patto identifica, tanto nas pesquisas educacionais, como na atuação dos professores da rede pública de ensino, uma tendência a assimilar o conceito de Bourdieu de capital cultural à teoria da carência cultural. Pratica-se em seu nome o que ela chama de violência simbólica, como forma de imposição da cultura das classes dominantes às camadas populares.

Nesse sentido, a autora denuncia em sua obra dedicada ao fracasso escolar:

\begin{abstract}
"o objetivo não era, portanto, garantir às classes subalternas a apropriação do saber escolar enquanto instrumento de luta pela transformação radical da sociedade, mas acenar para o pobre com a possibilidade de melhoria de suas condições de vida através de uma melhora de nível social e econômico, estruturalmente impossível para a maioria" (PATTO, 1990: 148-149).
\end{abstract}

\title{
1.3 - Os capitais - econômico, cultural, social e simbólico - à luz de Bourdieu
}

O antropólogo, filósofo e sociólogo francês Pierre Bourdieu (1930-2002) ressaltou que nas sociedades modernas e democráticas, não contava mais a suposta "superioridade de sangue", nem títulos de nobreza, mas a cultura passou a ser o elemento de distinção das elites.

No entanto, no contexto da escolaridade obrigatória e com a democratização do acesso à escola, deparou-se com o grave problema das desigualdades de escolarização entre os grupos sociais.

As inquietações teóricas suscitadas pelo campo da Sociologia apontavam para os mecanismos da reprodução social que legitimavam as diversas formas de dominação. Bourdieu ocupou um papel central no pensamento sociológico criticando as formas institucionais de dominação e de mascaramento da realidade social, desconstruindo a idéia de que os indivíduos seriam competidores no sistema de ensino em condições de igualdade e que os que se destacassem alcançariam, por justiça, uma melhor posição nas carreiras acadêmicas e posteriormente alçariam um lugar de destaque na hierarquia social. Para ele, as explicações como "dom" ou "aptidão natural" não seriam suficientes para o entendimento das razões que levavam certos grupos sociais a estarem mais ou menos identificados, e a circularem com mais desenvoltura no meio escolar.

Segundo o autor, foi a partir da forte expansão do sistema educacional do pós-guerra na Europa que esse fenômeno se evidenciou e resultou em uma série de pesquisas francesas, 
inglesas e americanas que apontaram claramente para o peso da origem social sobre os destinos escolares, minando, assim, o otimismo envolvido na concepção de que a educação pudesse servir como instância transformadora e democratizadora, por meio da qual haveria a possibilidade de ser construída uma sociedade justa, moderna e democrática.

Sua extensa obra, compreendendo artigos e livros publicados ${ }^{12}$, evidenciou que o sucesso escolar não está relacionado a talentos ou dons do indivíduo, mas que haveria uma forte relação entre a origem social (classe, etnia, sexo, local de moradia, entre outros) e o desempenho escolar, corroborados pela frustração dos jovens das camadas médias e populares que não alcançavam um novo patamar na hierarquia social. Bourdieu e Passseron ofereceram um novo olhar para o papel da escola e da educação e passaram a ver essas instituições como um dos principais locais de reprodução e legitimação das desigualdades sociais (1970).

Eles propõem uma resposta original para o problema das desigualdades escolares, trazendo uma nova leitura, no interior do pensamento sociológico, sobre o funcionamento social e as funções dos sistemas de ensino nas sociedades contemporâneas, bem como sobre as relações que mantêm os diferentes grupos sociais com a escola e com o saber.

Seu livro pioneiro, escrito com a colaboração de Jean-Claude Passeron - Les Héretiers (1964), constatou as vantagens dos estudantes nascidos em um meio onde a linguagem da escola era sua língua natural, jovens que desde o nascimento viveram em um meio mergulhado no 'savoir-vivre' e 'savoir-penser' que ele vai denominar - elite intelectual. Segundo o autor, essa elite recebe como herança um bem precioso, mas invisível a olho nu: a cultura.

Bourdieu (1989) abordou o espaço social como sendo um campo de lutas no qual os atores (indivíduos e grupos) elaboram estratégias que permitem manter ou melhorar sua posição social. Para ele, estas estratégias estariam relacionadas com os diferentes tipos de capital. Capital foi um conceito 'emprestado' da área econômica e utilizado no campo da Sociologia para estudar as desigualdades escolares, além de servir como metáfora para designar os privilégios culturais e sociais que indivíduos e/ou famílias possuem e que, geralmente, os conduzem a um nível socioeconômico mais elevado.

\footnotetext{
${ }^{12}$ Bourdieu \& Passeron, 1964 e 1970; Bourdieu, 1966; Bourdieu, 1979; Bourdieu, 1980.
} 


\subsection{1 - Capital econômico}

O capital econômico se efetivaria sob a forma de diferentes fatores de produção (terras, fábricas, trabalho) e do conjunto de bens econômicos (dinheiro, patrimônio, bens materiais). Sua acumulação e reprodução dependeriam de investimentos econômicos e culturais. A sua obtenção e manutenção se deveriam às relações sociais que permitiriam o estabelecimento de vínculos economicamente úteis, a curto e em longo prazo.

O capital econômico se acumula, segundo o autor, por meio de operações de investimento, o que permite extrair lucros de acordo com a capacidade do agente de operar as aplicações mais rentáveis, podendo, em certas condições, originar-se de herança.

Não obstante, a idéia de capital econômico não respondeu à problemática das desigualdades escolares, que demonstraram as limitações do conceito para explicar a relação entre nível sócio-econômico e bons resultados educacionais. Fez-se necessário considerar outras formas de capital, tais como o capital social e cultural, que, segundo Bourdieu, contribuem diretamente e interagem com o capital econômico para fortalecer o estabelecimento da ligação entre nível social e bom desempenho escolar.

\subsection{2 - Capital cultural}

Para Bourdieu (2005) ${ }^{13}$, a noção de capital cultural surge da necessidade de se compreender as desigualdades de desempenho escolar dos indivíduos oriundos de diferentes grupos sociais. A explicação das desigualdades escolares, de acordo com sua abordagem em sociologia da educação, se caracteriza, notadamente, pela importância dada ao fator cultural que atua como coadjuvante do fator econômico.

Para Bourdieu, acumulação e aquisição são aspectos da dinâmica do capital cultural que estão associados entre si. A acumulação inicial do capital cultural "começa desde a origem, sem atraso, sem perda de tempo, pelos membros das famílias dotadas de um forte capital cultural; nesse caso, o tempo de acumulação engloba a totalidade do tempo da socialização" (BOURDIEU, 2005:76 - grifo do autor), o que significa um empreendimento

\footnotetext{
${ }^{13}$ O trabalho de BOURDIEU, P. "Les trois états du capital culturel" foi originalmente publicado na revista Actes de la Recherche en Sciences Sociales, 30:3-6, 1979. (in: NOGUEIRA \& CATANI, 2005)
} 
prolongado de aquisição de capital cultural. Este é definido como o conjunto de qualificações intelectuais transmitidas pela família, pelo ambiente social ou produzidas pelo sistema escolar. Quando o grupo familiar assegura a seus membros maior tempo livre, estes podem dilatar o empreendimento de aquisição de capital cultural, adiando, por exemplo, a entrada no mercado de trabalho.

Uma das formas de capital cultural - a educação escolar - seria um recurso tão útil quanto o capital econômico na determinação e reprodução das posições sociais na sociedade. A distribuição desigual das diferentes formas de capital justificaria as diferenças de estratégias adotadas por cada indivíduo, com o intuito de entender como os diferentes agentes apreendem, por exemplo, as situações escolares e se acomodam a elas, ou como eles são excluídos do sistema educacional. Em suas investigações, principalmente realizadas com a colaboração de Passeron (1964; 1970), o autor vislumbrou como a seleção escolar eliminava e excluía ou colocava à margem os alunos oriundos das classes populares, enquanto privilegiava os alunos mais dotados de capital cultural e social, contribuindo, assim, para a reprodução, geração após geração, dos capitais econômico, cultural e social acumulados. Esta teoria contraria a convicção, até então amplamente aceita, de que existiria igualdade de chances no sistema educacional.

De acordo com essa análise sociológica, o capital cultural pode existir sob 3 formas:

No estado incorporado, ou seja, "sob a forma de disposições duráveis no organismo. (...) Está ligado ao corpo e pressupõe sua incorporação. A acumulação de capital cultural exige uma incorporação que, enquanto pressupõe um trabalho de inculcação e de assimilação, custa tempo que deve ser investido pessoalmente pelo investidor. (...) É um ter que se tornou ser, uma propriedade que se fez corpo e tornou-se parte da 'pessoa', um habitus" (BOURDIEU, 2005:74). Tem como principais elementos constitutivos, os gostos, o domínio maior ou menor da língua culta e as informações sobre o mundo escolar. No estado incorporado, o capital cultural "não pode ser transmitido instantaneamente (...) por doação ou transmissão hereditária, por compra ou troca. Pode ser adquirido, de maneira totalmente dissimulada e inconsciente, e permanece marcado por suas condições primitivas de aquisição" (BOURDIEU, 2005:75). Ele atua de forma mais marcante na definição do futuro escolar dos descendentes, uma vez que as referências culturais, os conhecimentos considerados apropriados e legítimos e o domínio maior ou menor da língua culta trazida de casa (transmissão hereditária) facilitam o aprendizado dos conteúdos e dos códigos escolares, 
funcionando como uma ponte entre o mundo da família e o da escola. Por ser herdado e adquirido apresenta um grau de dissimulação ${ }^{14}$ elevado e está predisposto a funcionar como capital simbólico.

Bourdieu tem como uma de suas teses centrais que o aluno ao longo de seu percurso escolar, traz uma bagagem social e cultural diferenciada - habitus -, conceito - chave de sua teoria, que corresponderia a uma matriz por meio da qual o indivíduo pensa, vê e age nas mais variadas situações; são disposições ou gostos "produzidos pelos condicionamentos sociais associados à condição correspondente e, pela intermediação desses habitus e de suas capacidades geradoras, um conjunto sistemático de bens e de propriedades vinculadas entre si por uma afinidade de estilo" (BOURDIEU, 1996:21).

O conceito de habitus foi introduzido para explicar o capital cultural. Em um curso realizado no ENDIPE $^{15}$, a Professora Zaia Brandão definiu o termo habitus como um sistema que envolve esquemas de percepção, de apreciação e de ação, ou seja, um conjunto de conhecimentos práticos adquiridos ao longo do tempo que permite perceber e agir num universo social. Ele se constitui a partir da exposição repetida a condições sociais definidas, imprimindo, no seio dos indivíduos, um conjunto de disposições sociais duráveis e transponíveis. As disposições são a interiorização da exterioridade, em outras palavras, tendências a perceber, sentir, fazer e pensar de certa maneira. São interiorizadas e incorporadas por cada indivíduo a partir de seu meio social e trajetória. As disposições sociais são duráveis apesar de modificáveis no curso das experiências; no entanto estão fortemente enraizadas nos agentes, como introjeção de atitudes, de disposições, etc. As disposições sociais além de duráveis são também transponíveis uma vez que decorrem da interiorização da necessidade de seu meio social.

O habitus resulta em princípios geradores de ações, isso é, uma multiplicidade de respostas em face das situações em que se encontram os agentes quando confrontados a situações habituais; e podem resultar em transformações - quando entre os habitus e as situações em que se encontram há um desequilíbrio freqüente, o agente é levado a modificá-lo para continuar no “jogo" (campo $\left.{ }^{16}\right)$.

\footnotetext{
${ }^{14}$ Aquisição que não é passível de ser percebida pelo próprio indivíduo.

${ }^{15}$ ENDIPE (Encontro Nacional de Didática e Prática de Ensino), Recife, 2006

${ }^{16}$ Ver item 1.3 .3 p. 36 sobre o conceito de campo.
} 
O estado objetivado corresponde ao momento em que o capital cultural se traduz por bens culturais objetivados, que funcionam como suportes materiais. Estes, apesar de sua aparência de objetos autônomos, podem ser apropriados e utilizados pelos agentes como estratégias de distinção e reconhecimento, envolvendo: escritos, pinturas, obras de arte, etc., bens socialmente valorizados e que possuem grande poder simbólico. Todavia, para se apropriar simbolicamente destes bens é necessário ter acesso aos instrumentos desta apropriação e os códigos necessários para decifrá-los, ou seja, é necessário possuir capital cultural no estado incorporado. O capital cultural, no estado objetivado, é transmissível em sua materialidade (na forma de bens concretos), mas o que torna possível seu usufruto é o capital cultural incorporado.

Já no estado institucionalizado, o capital cultural concretiza-se sob a forma de diplomas e certificados que conferem ao detentor um valor convencional, constante e juridicamente garantido no que diz respeito à cultura. $\mathrm{O}$ capital cultural institucionalizado se dá basicamente sob a forma de títulos escolares. O grau de investimento na carreira escolar está vinculado ao retorno provável que se pode obter com o título escolar, notadamente no mercado de trabalho. Esse retorno, ou seja, o valor do título escolar pode ser alto ou baixo a depender do grau de dificuldade para obtê-lo: quanto mais fácil o acesso a um título escolar, maior a tendência à sua desvalorização.

\subsection{3 - Capital social}

O capital social foi um conceito introduzido por Bourdieu para tentar entender como indivíduos inseridos em uma rede estável de relações sociais podem se beneficiar de sua posição. Ele define capital social como a agregação de recursos atuais ou potenciais que têm ligação estreita com uma rede durável de relações institucionalizadas de reconhecimento e de inter-reconhecimento mútuo; em outros termos, redes de relações e prestígio.

O autor recorre ao conceito de campo para referir-se ao espaço no qual as relações de poder se manifestam. Campo é, de acordo com sua definição (1996), um espaço de correlações de forças, lutas e conflitos, no interior do qual os agentes se enfrentam com meios e fins diferenciados conforme sua posição relativa na estrutura, o que por sua vez está relacionado ao seu interesse em conservá-la ou transformá-la. O que orienta as estratégias dos 
agentes é a posição que detêm no interior do campo; ali as ações são realizadas no sentido de um investimento em determinado tipo de capital, procurando sempre acumulá-lo.

Os campos se estruturam a partir de uma distribuição desigual de um quantum social que determina a posição ocupada por um agente específico. Esse quantum é denominado de capital social. Os agentes que possuem um quantum de capital social reconhecido pelo grupo, usufruem dos benefícios relativos às posições dominantes, enquanto aqueles que ingressaram recentemente em determinado campo, ou seja, que possuem um volume pequeno de capital social ocupam as posições inferiores do campo.

O capital social constitui-se de dois elementos: as redes de relações sociais, que permitem aos indivíduos ter acesso aos recursos dos membros do grupo ou da rede; e a quantidade e a qualidade de recursos disponíveis no grupo.

As redes das relações estabelecidas entre os indivíduos pertencentes a um determinado grupo não advêm apenas do compartilhamento de relações objetivas ou do mesmo espaço econômico e social, mas se fundem, também, às trocas materiais e simbólicas, cuja instauração e perpetuação supõem o reconhecimento dessa proximidade.

O segundo elemento diz respeito à quantidade e à qualidade de recursos do grupo. De acordo com o autor, o volume de capital social de um agente individual depende tanto da extensão da rede de relações que ele pode efetivamente mobilizar, como do volume das diferentes formas de capital (econômico, cultural ou simbólico), que é propriedade exclusiva de cada um dos agentes a quem o indivíduo está ligado.

O capital social pode ser explicado, de acordo com Bourdieu (1980) ${ }^{17}$, a partir de três aspectos: os elementos constitutivos; os benefícios obtidos pelos indivíduos mediante a participação em grupos ou redes sociais; e sob as formas de reprodução deste tipo de capital.

Os elementos constitutivos das redes sociais são a família, o clube, a escola, etc., que dão ao indivíduo o sentimento de pertencimento a um determinado grupo.

O segundo aspecto destacado focaliza os ganhos obtidos pelos indivíduos em decorrência de sua participação nos grupos. É esta participação que lhes permite apropriar-se dos benefícios materiais e simbólicos que circulam entre os membros da rede.

\footnotetext{
${ }^{17} \mathrm{O}$ trabalho de PIERRE BOURDIEU Le capital social: notes provisoires foi originalmente publicado in Actes de La recherche em sciences sociales, Paris, n. 31, janeiro de 1980, p.2-3. (IN: NOGUEIRA \& CATANI, 2005).
} 
Diretamente relacionada a essa apropriação está, em terceiro lugar, a reprodução do capital social, que é produto do trabalho necessário para produzir as redes de relações duráveis que podem proporcionar os benefícios materiais e simbólicos que circulam entre os membros da rede. Nessa perspectiva, destaca-se a importância do capital social para as diversas frações de classe, pelas possibilidades que sua participação em determinados grupos ou redes sociais lhes abrem, no sentido de aumentar o rendimento possível do seu capital social e de seus investimentos escolares, na forma de benefícios simbólicos.

O conceito de capital social defendido pelo autor é, assim, solidário com suas formulações sobre disposições duráveis (habitus). A noção de habitus enfatiza a dimensão de um aprendizado passado que tende a conformar e a orientar a ação. É o sistema de esquemas para a elaboração de práticas concretas, ou esquemas estruturados, incorporados pelos agentes sob a forma de um senso prático que facilita sua orientação nos domínios relativos à existência social.

A construção do capital social se dá no interior das redes familiares, fator importante para o desenvolvimento escolar e cognitivo dos filhos e para a construção de capital social extrafamiliar; ou seja, em redes fora do lar e no interior de contextos econômicos, estatais e/ou comunitários, formais e informais.

Na medida em que o habitus é produto das relações sociais, ele tende a assegurar a reprodução das mesmas relações objetivas que o engendraram. A interiorização pelos agentes de valores, normas e princípios sociais assegura a adequação entre as ações do sujeito e a realidade objetiva da sociedade como um todo. A ação é guiada por uma razão prática, que é a lógica do senso prático, "uma lógica em ação", que permite ao agente "agir quando necessário" e lhe possibilita um conhecimento prático no mundo social (BOURDIEU, 1996:50).

\subsection{4 - Capital simbólico}

Depreende-se da obra de Bourdieu que o poder simbólico é como um poder invisível, uma forma transformada das outras formas de poder - econômico, cultural, social, etc. - que se torna irreconhecível, transfigurada e legitimada. Nas palavras de Bourdieu, na "atividade produtora da consciência" (...) "os símbolos são os instrumentos por excelência de "integração social': enquanto instrumentos de conhecimento e de comunicação, eles tornam possível o 
consensus acerca do sentido do mundo social que contribui fundamentalmente para a reprodução da ordem social: a integração 'lógica' é a condição da integração 'moral'” (BOURDIEU, 2007:9-10)

[...] O poder simbólico como poder dado pela enunciação, de fazer ver e fazer crer, de confirmar a visão do mundo e, deste modo, a ação sobre o mundo, portanto o mundo; poder quase mágico que permite obter o equivalente daquilo que é obtido pela força (física ou econômica), graças ao efeito específico de mobilização, só se exerce se for reconhecido, quer dizer, ignorado como arbitrário (Bourdieu, 2007:14)

Bourdieu alertou para o papel do Estado diante da problemática educacional gerada pelas diferenças culturais na escola. Para ele, o Estado é uma macro-estrutura:

[...] resultado de um processo de concentração de diferentes tipos de capital, capital de força física ou de instrumentos de coerção (exército, polícia), capital econômico, capital cultural, ou melhor, de informação, capital simbólico, concentração que, enquanto tal, constitui o Estado como detentor de uma espécie de metacapital, com poder sobre os outros tipos de capital e sobre seus detentores (BOURDIEU, 1996:99).

Ressaltou ainda, que um dos principais poderes do Estado seria, por isso mesmo, de “produzir e impor (especialmente por meio da escola) as categorias de pensamento que utilizamos espontaneamente a todas as coisas do mundo, e ao próprio Estado (...) mostra(ndo) o perigo que sempre corremos de ser pensados por um Estado que acreditamos pensar" (BOURDIEU, 1996:91).

Resta esperar que a escola possa desempenhar o papel de auxiliar no processo de construção do conhecimento dos seus alunos no sentido de promover uma abertura para o mundo, porque a concorrência no mercado de trabalho, o apelo consumista, os modelos que servem como referência para os jovens nesse mundo (veiculados pela mídia, sobretudo) concorrem com um modelo de escola antiquada e disciplinar, que define a aprendizagem como algo extremamente linear, um passo a passo, do mais simples ao mais complexo, do mais concreto ao mais abstrato.

Foi pensando nessas questões que nos perguntamos se os estudantes das camadas populares que ingressaram na escola pesquisada não estariam sobremaneira impregnados do seu próprio capital cultural advindo de uma mescla de tradição familiar e cultura jovem urbana, e de que forma a escola contribuiria para sua formação acadêmica valorizando as suas características, sem impor uma cultura da classe dominante. A pergunta que surgia ao longo da pesquisa é se havia e haveria mudanças? E que mudanças seriam essas? Acreditamos que a escola ao inovar assumindo a clientela das camadas populares tenha como objetivo 
educacional ser uma instância transformadora e democratizadora das sociedades, de modo a ampliar as opções de vida de seus alunos, não ficando restrita apenas à sua formação profissional embora, por si só, já seria válida.

\subsection{5 - Mudança do habitus}

Para a socióloga Zaia Brandão (2005) esta questão sobre as possibilidades de mudança do habitus, de transformação social, de autonomia e de ação do individuo é bastante recorrente nos programas de pós-graduação, e na sua opinião, a transformação do habitus é um dos pontos menos trabalhados por Pierre Bourdieu. Ela aponta os estudos de dois críticos da teoria de Bourdieu: Jean-François Dortier (2002) que critica a dificuldade desse autor de pensar a mudança e de Founier (2002) que acusa Bourdieu de substituir um fatalismo genético por um fatalismo sociológico.

Brandão explica (2005) que para Bourdieu o que move o homem no mundo não é a razão de "São Tomás de Aquino", isto é a razão pura, mas sim razões práticas. O individuo é situado e 'enredado' pelo espaço social que o contém, mas ele pode compreendê-lo e agir sobre ele. A oposição tradicional em ciências sociais entre determinismo social e individualismo metodológico é, segundo Bourdieu, uma falsa oposição. Uma das funções principais do habitus é descartar dois erros complementares: de um lado, o mecanicismo, que vê a ação como um efeito direto do constrangimento de causas externas; de outro, o finalismo, que, vê que o agente age de maneira livre e consciente orientado teologicamente pela razão. Com a noção de habitus, Bourdieu pretendeu descartar outra oposição sumária: aquela que opõe, em termos científicos, indivíduo e sociedade "oposição que a noção de habitus enquanto social incorporado, logo, individuado, visa superar" (1990; 2004:45). Não só o individuo é situado em um universo social particular, mas o universo social é inscrito nele. Ele engloba a sociedade tanto quanto ela o engloba.

Já falamos da indissociabilidade da relação entre os conceitos de campo e habitus, pois o habitus é um saber agir aprendido pelo agente na sua inserção em determinado campo. 
Brandão (2005) pretende escapar do determinismo social ${ }^{18}$, sustentando que há possibilidade de mudança de habitus:

\begin{abstract}
[...] a movimentação dos agentes no espaço social (trajetórias/estratégias) atravessando os diferentes campos com relações e permanências diferenciadas segundo os interesses que os mobilizam (sempre condizentes com o habitus de que são dotados) - repercute na modificação da estrutura e volume de capitais dos diferentes agentes. [...] Assim as possibilidades de transformação dos habitus dos agentes podem ser pensadas, por um lado, a partir da movimentação dos agentes entre diferentes campos sociais, e, por outro, a partir da movimentação e das lutas travadas dentro do próprio campo. Outrossim, a transformação do habitus pode ocorrer através de um trabalho de análise reflexiva (portanto racional) sobre as próprias disposições, conforme menciona Bourdieu em algumas entrevistas (BRANDÃO, 2005:5).
\end{abstract}

Conforme dissemos no início deste capítulo, campo para Bourdieu (1996) define-se como o espaço de correlações de forças, lutas e conflitos, no interior do qual os agentes se enfrentam com meios e fins diferenciados conforme sua posição relativa na estrutura. Ora, se há tensão e luta, conseqüentemente há movimento e mudanças permanentemente. Brandão (2005) acrescenta nesse sentido: os agentes sociais são eles mesmos portadores de capital e, segundo sua trajetória e a posição ocupada por eles, terão propensão a se orientar ativamente, seja em direção à conservação da distribuição do capital, seja em direção à subversão desta distribuição. Considerando que o habitus se forma a partir da inserção do agente nos diferentes campos sociais e das lutas travadas no interior dos mesmos, mudanças nas posições no campo e na distribuição de capitais implicam em modificações no próprio habitus. A complexificação do habitus decorrente das possibilidades de circulação dos agentes por vários campos hipoteticamente oferece maiores condições para a sua diversificação estrutural; assim como de aumento do volume total do capital. É fato que quanto mais capital específico acumulado, mais condições têm os agentes de dominar o jogo. No entanto, é preciso observar que, na perspectiva dinâmica das relações habitus/capitais-campos, continua Brandão, nenhuma conquista de posição é definitiva, pois o espaço social é constituído por um conjunto de campos relativamente autônomos, mas que, ainda assim, alteram-se permanentemente em função da movimentação dos agentes intra e extracampos (BRANDÃO, 2005: 8-9).

Nesse sentido, se apreendermos a teoria sociológica de Bourdieu de uma maneira crítica, é possível pensar a transformação do habitus inspirados na trajetória de vida do próprio sociólogo, que nasceu filho de um carteiro e de uma família camponesa pelo lado

\footnotetext{
${ }^{18}$ Para Founier (2002) o determinismo social é um fatalismo sociológico que não possibilita o resgate dos indivíduos de uma trama social.
} 
materno e foi criado em uma pequena vila onde prevalecia a cultura camponesa. No entanto, alçou as mais altas esferas acadêmicas. Ironia à parte, conforme a observação de Loic Wacquant (Wacquant In: PEREIRA, 2007), o sociólogo Raymond Aron ${ }^{19}$ observou que justamente Bourdieu foi uma exceção às leis de transmissão do capital cultural que tanto defendeu em sua teoria.

\section{4 - As relações das práticas socializadoras escolares com as das famílias das classes populares}

É indiscutível a importância da teoria crítica-reprodutivista de Bourdieu e Passeron que alterou definitivamente o pensamento educacional brasileiro ao colocar em foco a dimensão sócio-cultural do processo ensino-aprendizagem em contraposição a uma concepção tecnicista de ensino; bem como o alerta sobre a presença na escolarização, sobretudo das camadas desfavorecidas, da dominação e discriminação social, do antagonismo das classes sociais e a inexistência de um aluno ideal tal como desejaria o professor, acrescentada da possibilidade de a educação escolar ser pensada a partir de seus condicionantes sociais, conforme constatou Patto (1997).

Na trajetória dos estudos e pesquisas da teoria de Bourdieu encontramos vários autores que deram continuidade à sua obra. Acreditamos que seria enriquecedor para a nossa pesquisa o estudo do sociólogo Daniel Thin (2006), que abordou a questão da disparidade cultural em sentido contrário às idéias que tendem a atribuir as dificuldades da escolarização à carência cultural ou à negligência educativa das famílias populares. Thin tratou dessa questão a partir da análise das relações entre as famílias populares e a escola, ou mais precisamente da relação das famílias populares com a escolarização.

Foram encontrados poucos estudos dedicados a entender a escolarização do ponto de vista das famílias, e especificamente, das famílias das camadas populares como a pesquisa de Daniel Thin sobre as práticas escolares e as familiares. As pesquisas de Thin investigam a relação das famílias populares com a escola, ambas agências educativas das sociedades contemporâneas. Seus achados são muito próximos do que vivenciamos no Brasil com as famílias apontadas como demissionárias da sua tarefa educativa em prol da escola.

\footnotetext{
${ }^{19}$ De quem Bourdieu foi assistente na direção do Centro Europeu de Sociologia Histórica.
} 
Em muitos casos, as culturas e as lógicas escolares de socialização são distintas e mesmo opostas às culturas e lógicas de socialização das famílias populares. Estas duas lógicas apontam para práticas socializadoras que são freqüentemente contraditórias, tecidas por lógicas antinômicas: de um lado, os professores, cujas lógicas educativas fazem parte daquilo que chamamos modo escolar de socialização; de outro lado, famílias populares com lógicas socializadoras estranhas ao modo escolar de socialização.

Consideramos como um avanço, o fato de Thin investigar essa relação evitando o discurso adotado do ponto de vista da instituição escolar que insiste em perceber as ações das famílias sempre como portadoras de um déficit educativo. A partir do uso do conceito de capital cultural criado por Bourdieu (1979a, 1979b), Thin buscou uma explicação para as diferenças entre as classes sociais nas suas relações com a escola. Sua análise parte dos pressupostos encontrados na teoria educacional, segundo os quais, as relações familiares das camadas populares com a escola são entendidas como:

- fraqueza dos recursos culturais e escolares dos pais;

- efeitos de dominação gerados por essa relativa fraqueza em termos de capital cultural;

- relações entre indivíduos ou grupos que ocupam posições diferentes no espaço social: de um lado, os professores, membros das classes médias assalariadas e de outro, as famílias populares pertencentes às classes sociais mais desprovidas e mais dominadas no espaço social;

- e, por fim, "as relações entre famílias populares e escola surgem das relações entre instituições de socialização e enquadramento dos membros de classes populares, consideradas na perspectiva de um controle social exercido sobre as famílias" tentando "impor aos pais outras práticas socializadoras ou outras regras familiares de vida" (THIN, 2006:211-212).

Thin considera que efetivamente as famílias das classes populares possuem um "fraco capital cultural" se for visto segundo o critério de capital cultural no estado institucionalizado, que, conforme assinalara Bourdieu, seria medido por meio de diplomas e do número de anos de escolarização dos pais. A esse respeito, o autor adverte: 
[...] seria um erro esquecer que as "carências" das famílias e de suas crianças só existem em relações sociais desiguais, que impõem a posse de aptidões acadêmica e socialmente reconhecidas, e estabelecem as características dos membros das classes populares como negativas e inferiores. A inferioridade não é uma substância, não está na natureza dos sujeitos sociais que a portariam por acaso, ela é o produto de relações sociais cujo equilíbrio de forças é desigual (THIN, 2006:223).

Thin julga que embora o capital cultural possa ser um indicador valioso por classificar os sujeitos sociais e suas práticas, no entanto, não agrega a diversidade e a complexidade das práticas, Uma vez que desconsidera os modos como os pais se apropriam da escolaridade de seus filhos e o sentido que eles atribuem a isso, e suas práticas socializadoras familiares.

Utilizaremos a noção de socialização definida por Barbosa (2007) como "algo que se faz junto, é a forma com que os seres humanos praticam as suas ações, vivem suas vidas, evidenciam seus valores, constroem e defendem suas idéias" (BARBOSA, 2007:1065).

No estudo sobre essas questões há que se acrescentar que as instituições escolares contemplam dois modos de socialização: um, escolar e dominante; o outro, popular e dominado. É essencial a análise de questões centrais, que são deixadas de lado, e envolvem a escolarização e as famílias populares como as "maneiras de estar com as crianças, maneiras de examinar as aprendizagens, maneiras de comunicar, ou, ainda, maneiras de regular os comportamentos infantis ou juvenis" (THIN, 2006:212).

Thin desafia que se mude a visão dominante que rotula as formas familiares de socialização das camadas populares como incoerentes e negligentes e se "considere que as práticas e as maneiras de fazer dos pais não são totalmente incoerentes, que elas têm sua própria lógica, ou melhor, que elas não parecem incoerentes senão quando confrontadas com as normas da escola e, de modo mais amplo, com as normas dominantes da vida social" (THIN, 2006:213). Para ele, a socialização não é o único produto da ação das instituições construídas ao longo da história, mas um processo contínuo de inserção cultural, produto das relações sociais (mais ou menos institucionalizadas); ela conhece variações em função das diversas configurações de relações sociais nas quais se produz e das quais os indivíduos participam. "Entender desse modo a noção de socialização permite pensar os desvios e as diferenças de socialização em função dos pertencimentos e das trajetórias sociais, como também pensar nas tensões entre lógicas de socialização divergentes" (THIN, 2006:213). 
Thin busca apresentar a confrontação que se observa entre os dois conjuntos de lógicas socializadoras - a saber, da escola e das camadas populares - nas práticas socializadoras em relação à autoridade, em matéria de linguagem e em relação às atividades lúdicas do jogo. Para isso analisa os seus pontos de distanciamento, sejam de diferença, algumas vezes mesmo de oposição, mas partindo do princípio que são pontos conflitantes "de natureza estrutural", pois estão fundamentadas na estrutura das relações sociais que se entrecruzam, como vimos a partir dos estudos de Bourdieu, com as dimensões econômicas e culturais. E Thin faz a ressalva que essa confrontação é desigual porque se dá entre dois pólos: o pólo dominante das lógicas escolares e o pólo dominado das lógicas populares. Assim descreve como se dá o doloroso processo de escolarização das camadas populares:

- as práticas e as lógicas escolares tendem a se impor às famílias populares;

- os pais, cientes da importância da escola na vida dos filhos, são obrigados a participar do jogo da escolarização tendo pouco ou nenhum domínio dos conhecimentos e das formas de aprendizagem escolar, além de dominarem mal as regras da vida escolar;

- os professores como agentes da instituição escolar têm o poder de impor às famílias que elas se conformem às exigências da escola;

- os pais carregam consigo o sentimento da ilegitimidade de suas práticas ao mesmo tempo em que conferem legitimidade às práticas dos professores.

Não obstante, essa confrontação entre as lógicas escolares e as das famílias populares:

\footnotetext{
"não significa que as relações sejam necessariamente conflituosas mas que há uma tensão constitutiva das relações entre as lógicas e as práticas mais ou menos antinômicas, essa tensão pode ser solucionada por ajustes recíprocos, por apropriações mais ou menos conformes às lógicas escolares, ou ainda por uma coexistência em que os protagonistas das relações se mantenham distantes uns dos outros" (THIN, 2006:215).
}

Mas ele faz a ressalva de que a confrontação desigual e o predomínio do modo de socialização escolar causam desconforto em ambos os pólos: por tornar mais complexo o trabalho dos professores diante das práticas dos pais; e estes, por seu lado, ficarem constrangidos e se desestabilizarem em suas práticas socializadoras com seus filhos e até duvidarem de sua autoridade parental. 
Talvez uma das mais importantes contribuições de Thin seja sua análise das diferenças entre as práticas socializadoras escolares e as das famílias populares.

A forma escolar de socialização se dá fora da vida social comum, com as crianças separadas do seu mundo familiar e divididas por faixa etária num espaço fechado e resguardado dos olhares não-pedagógicos. Caracteriza-se por ter um espaço e um tempo específicos que acontece unicamente na escola, com ritmos próprios e um tempo mínimo livre de atividade educativa. A forma escolar é antes de tudo uma relação pedagógica cujo objetivo é a educação, dada através de atividades cujo intuito é formar as mentes e os corpos dos alunos. O papel dos adultos, os agentes educativos, é de ocupá-los o tempo todo. Aprende-se por meio de exercícios cujo fim é a aprendizagem, que passa pela aprendizagem das regras, quais sejam: gramaticais, de matemática, de apresentação, etc. A relação entre professor e aluno baseia-se em regras impessoais (independente da empatia por algum aluno ou do humor do professor). Enfim como assinala Thin: "por meio das aprendizagens desenvolve-se um trabalho educativo e moral" (THIN, 2006:216).

Já as lógicas socializadoras populares acontecem no ambiente popular, principalmente através dos atos da vida cotidiana, na convivência entre adultos e crianças, sem separações da vida comum e sem que haja um tempo específico para que esse processo de socialização se instaure. 


\subsection{1 - A ação da autoridade}

O exercício da autoridade dos pais faz-se sentir por meio de uma vigilância constante visando o controle do comportamento e não a transmissão de uma moral em que as crianças aprendam a discernir o certo e o errado ou conhecer regras de segurança: "os pais das famílias populares comumente usam castigos corporais para punir os atos repreensíveis" (THIN, 2006: 217). Thin afirma que encontrou poucas regras para o comportamento das crianças, no entanto não se podem ultrapassar os limites estabelecidos de forma imperativa pelos pais. Em casos de transgressão, há sanções aplicadas claramente, ligadas diretamente ao ato reprovado, cujo objetivo é interromper o ato. Por isso mesmo, quando os professores pedem para que os pais intervenham no sentido de regular o comportamento dos seus filhos na escola, sentem-se impotentes e devolvem a tarefa para os professores.

Já a escola, em princípio, valoriza a autonomia da criança, na medida em que a situação educativa incentiva a "busca de produção de uma auto-obrigação e de uma autodisciplina na criança, para que ela estabeleça suas práticas, seus comportamentos, de acordo com suas próprias regras, normas ou leis" (THIN, 2006:217).

Essas distintas formas do exercício da autoridade denunciam a distância entre as práticas socializadoras das camadas populares e as escolares. Os agentes educativos podem avaliar os pais como fracos em sua autoridade diante dos filhos. Como resultado, estes podem se sentir desqualificados por terem pouco domínio sobre o comportamento dos seus filhos e também porque seu modo de repreendê-los seria considerado muito violento e/ou prejudicial à autonomia das crianças. Estas, por sua vez, ao descobrirem outro modo de autoridade na escola, podem questionar a autoridade parental, principalmente em famílias, segundo Thin, que se encontram "alteradas por condições de existência degradadas, afetadas pela precariedade econômica" (THIN, 2006:219). Nesse processo, há a desqualificação simbólica do papel dos pais na educação dos filhos agravada por sua desqualificação no âmbito social. Acresce-se a isso, que, por imposição dos horários de trabalho, os pais se sentem impedidos, muitas vezes, de estar presentes em momentos importantes da vida familiar. 


\subsection{2 - A linguagem e a comunicação}

O problema da linguagem, na leitura de Thin, revela que os professores "lamentam o que identificam como uma falta de vocabulário dos alunos, dificuldades de ingressar no mundo da escrita e da linguagem escolar" (THIN, 2006: 219) e atribuem que essas dificuldades resultam do meio social em que as crianças vivem. Ora, Thin sustenta que as práticas linguageiras nas famílias populares surgem de uma linguagem pouco descontextualizada, pois são fortemente ligadas aos acontecimentos que estão ocorrendo ou que foram vivenciados em conjunto. Além dessa forte contextualização dos discursos, a linguagem caracteriza-se por muitos subentendidos, "como prova, por exemplo, o emprego recorrente de expressões dícticas, assim como de locuções que só designam com precisão as coisas e as pessoas por meio do emprego de pronomes dêiticos (ele, ela, nós...) para nomear alternadamente, e sem referência explícita, contextos ou indivíduos que, no entanto, são distintos na ordem do discurso" (THIN, 2006: 219). Pode-se pensar que a ligação entre o contexto conhecido dos interlocutores e a preponderância do "nós" (do coletivo) sobre o "eu" (o indivíduo) na socialização dispensa a explicitação necessária à comunicação escolar ${ }^{20}$.

Além dessa contextualização e do uso recorrente de pronomes de tratamento nas práticas socializadoras das famílias populares, a comunicação que se estabelece com as crianças é uma comunicação prática que visa à troca, antes de qualquer outra finalidade, sem nenhuma conotação pedagógica. Os professores lastimam que os pais não realizem um trabalho explícito sobre a linguagem com seus filhos, no sentido da linguagem ser considerada um objeto de troca educativa, designando as coisas sem ter em vista qualquer utilidade prática, ou mesmo corrigindo as frases das crianças.

Assim a diferença da linguagem é mais um fator de dificuldade escolar para as crianças ao mesmo tempo em que potencializa as tensões nas relações entre professores e pais porque as famílias são mais uma vez avaliadas como deficientes no plano lingüístico e as distâncias sócio-lingüísticas ficam mais evidenciadas nas interações dos pais com os agentes da instituição escolar.

\footnotetext{
${ }^{20}$ Pesquisas realizadas no NOAP - Núcleo de Orientação e Atendimento Psicopedagógico da PUC-Rio constatam que esse processo de comunicação pode ser correlacionado ao aspecto figurativo da construção da inteligência da teoria piagetiana. Os comportamentos figurativos são os que organizam os objetos segundo suas relações no espaço e no tempo, tendo em conta noções topológicas ou infra-lógicas. O esquema fundamental da atividade figurativa é a imagem (Mamede-Neves et alii, 1987; Vasconcellos, A.C., 1993).
} 


\subsection{3 - Os ritmos escolares e os populares}

Quanto ao distanciamento da temporalidade do ambiente escolar este é marcado pela regularidade temporal escolar observada na distribuição dos horários, na organização do calendário bem como pela sucessão de atividades pedagógicas organizadas de acordo com o emprego do tempo e da progressão nas aprendizagens.

No caso das famílias, constata Thin, outras temporalidades aparecem. As relações objetivadas do tempo pouco aparecem em agendas, calendários, relógios porque seus membros são pouco escolarizados ou porque vêem de universos culturalmente afastados desse tipo de racionalidade temporal ${ }^{21}$.

Além desses fatores, Thin assinala também a falta de trabalho estável ou a precariedade do emprego e mesmo o desemprego dos pais das famílias populares como ausência de divisão temporal no seu cotidiano. "Essas famílias mais desprovidas são assim condenadas a 'viver cada dia com sua agonia', o que impossibilita qualquer planificação e antecipação da existência" dificultando até mesmo as reuniões com os agentes de instituições. Em contrapartida há os pais que estão empregados e, no entanto, sem a disponibilidade para usufruir de seu horário de trabalho (por força das escalas) de maneira a estar de acordo com “os ritmos dos filhos e os ritmos que sua escolarização exige” (THIN, 2006:220).

\footnotetext{
21 Thin atribui ao fato da emigração estrangeira na França. Não é a mesma problemática do Brasil cuja maioria da população é de brasileiros.
} 


\subsection{4 - A expectativa da escola}

Para as famílias de baixa renda o sentido da escola baseia-se no que Thin define como "lógica da eficácia"; ou seja, nas possibilidades sociais que ela viabiliza seja em termos de futuros profissionais seja em matéria de conhecimentos que permitam que o sujeito os utilize com um bom aproveitamento na vida cotidiana. Ele exemplifica com os exercícios escolares que são considerados por essas famílias atividades que contribuem para alcançar resultados traduzidos em notas, na passagem de uma classe para outra, naquilo que eles permitem conquistar socialmente. Desse modo, as atividades escolares só fazem sentido se associadas aos objetivos sociais que esperam da escolarização de seus filhos; qualquer atividade que não seja ligada a esse objetivo, é considerada inútil, pura perda de tempo. Para Thin isso é gerado pela forte cisão entre trabalho e jogo, entre trabalho e descanso que ele afirma ser característica das classes populares. "Para os pais, a escola está classificada ao lado do trabalho, e tudo aquilo que se assemelhe ao jogo parece inútil ou nefasto à escolaridade" (THIN, 2006:221).

Os pais das famílias populares investem na escolarização mediante sua finalidade prática e em curto prazo. Entretanto, já do ponto de vista da lógica pedagógica esta acredita na duração, que coloca o sentido das aprendizagens em objetivos mais distantes e mais gerais cujos fins só se desvelam em longo prazo, no domínio dos procedimentos intelectuais abstratos. As expectativas dos professores em relação aos pais dos alunos são de que eles acompanhem regularmente o trabalho escolar de seus filhos. No entanto, os pais, principalmente os que menos acumularam capital escolar, isso é, os mais desprovidos de saberes e pedagogia escolares, preferem não participar por se sentirem incompetentes e até mesmo com temor de prejudicar seus filhos. Outros pais tendem a querer complementar a tarefa escolar, em um superinvestimento, acrescentando tarefas ou tentando antecipar as aprendizagens escolares, o que vai de encontro com a proposta educativa das escolas, e com a lógica pedagógica atual que supõe que os alunos construam um aprendizado mais autônomo no trabalho escolar e desse modo alcancem a autonomia na vida social.

Essa confrontação entre a escolarização das famílias populares e dos agentes educativos causa tensão, pois os pais são censurados nas suas iniciativas, ou na sua frouxidão frente a sua participação na tarefa educativa. 
Para Thin as lógicas socializadoras que se encontram nas classes populares são dominadas e ilegítimas por não estarem livres das influências das lógicas escolares. Os pais percebem a ilegitimidade de suas práticas e a legitimidade das práticas escolares, as quais suscitam um sentimento ambivalente nos pais de reconhecimento do valor e da importância da escola e, concomitantemente, de desconfiança, mantendo-se distantes em relação à instituição escolar. $\mathrm{O}$ autor assinala que essa ambivalência, essa mistura entre confiança e desconfiança, esse sentimento de que a escola não é feita para eles, é observada na postura dos pais que pedem para o professor rigidez, mas protestam diante de algumas imposições escolares; ou quando exigem que a manutenção da ordem escolar seja correspondente à autoridade familiar, mas querem defender os membros de sua família do poder dos agentes educativos, alegando injustiça ou estigmatização a respeito de sua família.

Essa oscilação observada por Thin nas famílias populares deverá ser vista pelas instituições educativas como modos ou práticas de apropriação da situação escolar que elas não sabem como lidar. Segundo o autor, é essencial o estudo concreto das apropriações sobre as relações das famílias populares com a escola para que possam efetivar seus pontos de encontro e seus efeitos

[...] sem cair no impasse que consiste em opor aquilo que seria uma resistência àquilo que seria uma submissão das famílias populares às lógicas escolares. Ele (o estudo) possibilita evidenciar as práticas que são, simultaneamente, aceitação do jogo escolar, submissão às determinações da escola e alteração das lógicas escolares por sua conversão à ordem das lógicas populares (THIN, 2006:223). 


\section{Capítulo 2 - A Congregação Filhas de Jesus}

\section{1 - A história da Congregação das Filhas de Jesus}

O século que se seguiu à Revolução Francesa foi um período marcado por mudanças rápidas, mas profundas, com o surgimento do espírito público envolvido na noção moderna de cidadania. A esse respeito, Boto afirma que: "A modernidade elegia a cidadania como referência e álibi para sustentação de uma sociedade que não equacionava as distâncias e desigualdades sociais" (BOTO, 1996:16).

Demograficamente, segundo Hobsbawn (1977; 2007:24) em 1800 a Europa tinha cerca de 187 milhões de habitantes (hoje tem cerca de 600 milhões). A maioria dos seus habitantes não sabia ler e, em virtude da escassez e do parco desenvolvimento dos sistemas de transporte, dificilmente as pessoas percorriam longas distâncias. As sociedades européias tinham ainda uma cultura eminentemente oral, sendo as práticas de leitura confinadas a diminutas comunidades de letrados, em um ambiente que se assentava em um mundo essencialmente rural. A população urbana, por exemplo, só veio ultrapassar a população rural, pela primeira vez, em 1851, na Inglaterra.

A revolução de idéias que dominava a cena internacional européia durante a maior parte do século XVIII esteve no centro de repetidos períodos de guerra conforme nos relata Hobsbawn (1977). Em certo sentido, estava em pauta o conflito entre os velhos e os novos regimes. Essa influência cultural corria para todos os cantos. Diz ele ser mais correto chamarmos de Iluminismo a ideologia revolucionária, uma vez que implicou na abolição da ordem política e social vigente na maior parte da Europa durante a Idade Média.

Renato Ortiz (1988; 2006b) ao se debruçar sobre a questão da cultura de massa brasileira traçou uma comparação entre a história do projeto de modernização europeu e aquele verificado na América colonizada, mais especificamente no Brasil.

Para Ortiz a emergência do capitalismo trouxe, em linhas gerais, mudanças estruturais que se passaram no campo da cultura européia e provocaram duas transformações em relação ao antigo regime (ancien régime): “a autonomização de determinadas esferas (arte, literatura) e o surgimento de um pólo de produção orientado para a mercantilização da cultura. São transformações profundas que correspondem ao advento da ordem burguesa, que traz com ela 
o desenvolvimento de um mercado de bens culturais e no interior do qual certas atividades se constituem em dimensões específicas da sociedade" (ORTIZ, 2006b:18). A arte e a literatura européias se separam definitivamente de outros condicionantes sociais (como a ideologia religiosa) e se mobilizam em busca de novas formulações para uma melhor expressão da realidade em movimento. Essa época marca a expansão de um mercado consumidor mais característico de uma sociedade de massa.

No entanto, conforme Ortiz (1988) alega, o ideário liberal chegou antes do desenvolvimento das forças sócio-econômicas, com um processo de democratização da cultura no Brasil e o advento da cultura de massa brasileira bastante tardios, de modo distinto da cultura européia, pelo fato do capitalismo ter sido introduzido no Brasil antes de uma mudança estrutural onde toda a população tivesse direito à cidadania, e não somente parte da sociedade. $\mathrm{O}$ autor alega que a classe burguesa, por querer se modernizar, assumia o discurso capitalista de maneira defasada entre a transmissão de um ideal capitalista numa sociedade que jamais conseguiu escapar da herança escravagista dos tempos coloniais, cujo projeto de remodelação urbana seria mais de fachada, ornamental nas palavras de Ortiz, pois desde essa época já se encontrava a presença de favelas nas metrópoles brasileiras (e continuam a persistir em pleno século XXI).

É nesse contexto que nos aproximamos da história espanhola, berço da Congregação Filhas de Jesus.

A Espanha no século XIX sofria o choque entre o liberalismo e o tradicionalismo e com a morte de Fernando XII, em 1833, houve uma disputa pelo trono entre os alfonsinos que apoiavam a jovem rainha Isabel II e os que queriam ver coroado o irmão do rei, Don Carlos. Essa rivalidade resultou em três guerras denominadas carlistas, estes considerados porta-vozes da idéia de uma monarquia tradicionalista ultra-católica em oposição ao monarquismo alfonsino que consideravam corrompidos pelo liberalismo do século XIX. Entre 1814 e 1874 houve, segundo Beevor (2007), trinta e sete tentativas de golpe, das quais doze foram bem sucedidas resultando em um grande período de instabilidade política na Espanha com graves conseqüências econômicas.

A classe média espanhola, influenciada, de um lado, pelas idéias iluministas em contraposição à rigidez da ordem governante e, de outro, pressionada pelo atraso comercial, iniciou uma revolução, antes de boa parte da Europa. 
Segundo Beevor (2007) o país tinha uma população de mais de dezoito milhões e meio de habitantes, mas a falta de condições de vida e a pobreza em alto grau fizeram com que mais de meio milhão de espanhóis emigrassem para o novo mundo somente na primeira década do século XIX. A expectativa de vida era por volta de 35 anos, ainda a mesma do século XV. O nível de analfabetismo, embora variável entre as regiões, era em média de $64 \%$ dos espanhóis e dois terços da população ativa da Espanha ainda trabalhava na terra. Já no Brasil, as taxas do analfabetismo eram ainda mais elevadas segundo Ortiz (2006), cuja população somava $84 \%$ de analfabetos em 1890, e um público de leitores bastante restrito, e, conseqüentemente com uma produção de livros praticamente inexistente.

\subsection{1 - A fundação}

É nesse ambiente que começou a vida de uma mulher analfabeta, Madre Cândida Maria de Jesus, como a maioria dos espanhóis dessa época, que fundou uma congregação religiosa. Desconhecia qualquer outra língua que não a sua - o Vasco (euskera), e trabalhava como empregada doméstica em casa de família. É curioso observar que justamente uma pessoa como ela, com uma preparação intelectual quando muito elementar, perseguiu o objetivo de elevar o nível cultural da mulher. Assim é que em 8 de dezembro de 1871, nascia a Congregação das Filhas de Jesus, em Salamanca dedicada à educação da juventude feminina, ainda hoje presente em muitos países europeus, americanos, latinos e asiáticos.

Madre Cândida foi batizada com o nome de Juana Josefa Cipitria y Barriola (1845 1912) em Andoain (Espanha) na aldeia Berrospe, no País Basco ${ }^{22}$, oriunda de uma família numerosa muito pobre. Durante sua juventude, trabalhou para ajudar no sustento de sua casa, sempre demonstrando forte identificação religiosa e grande consideração pelos pobres. Identificou-se com a corrente religiosa que sustentava que a Igreja deveria ser sensível a "todos os que sofrem a história a partir de situações de necessidade ou de pobreza, que cura e ensina” (TOMERO, 1990:8).

Juana Josefa, por ser a primogênita, não pôde ir à escola, pois precisava ajudar a criar suas seis irmãs enquanto sua mãe trabalhava com seu pai no tear.

\footnotetext{
${ }^{22}$ O país divide-se em comunidades autônomas, e algumas destas comunidades como a Galícia, o País Basco e a Catalunha têm identidade nacional e línguas próprias.
} 
Com dezoito anos, tomou a decisão de se tornar freira, contrariamente à opinião de seus pais e enquanto amadurecia essa idéia, foi trabalhar em Burgos, berço de Castilla. Lá conheceu, em 1869, o padre jesuíta Miguel de San Jose Herranz (1819 - 1896), que a convidou para fundar a "Obra de Educação Cristã para a Mulher". Esta experiência marcou sua trajetória e a influência dos ensinamentos jesuítas na filosofia da Congregação, pois o padre Herranz teve uma presença atuante na criação e história da instituição.

Conta a história da Instituição Religiosa das Filhas de Jesus que esta teve início na Semana Santa de 1869, no dia 2 de abril, na Igreja de El Rosarillo, em Valladolid. A irmã Maria del Carmen de Frias Tomero, desta congregação religiosa, escreveu um livro biográfico da Madre Cândida (1990) baseada nas fontes documentárias da auto-biografia da fundadora que esta, então com 24 anos, estava a orar quando teve uma inspiração que atribuiu a uma revelação divina: "Te chamarás desde hoje, Cândida Maria de Jesus... fundarás uma congregação: as Filhas de Jesus" (TOMERO, 1990:61). Ela fundou essa Congregação, com esse mesmo nome, imbuída da missão de "salvar" alunas por meio da educação, criando uma instituição dedicada à infância e à juventude.

Ainda sem saber ler e escrever iniciou sua alfabetização aos 24 anos de idade e quatro anos depois conseguiu se alfabetizar em uma língua diferente da língua materna. Em oito de dezembro de 1871, fundou a Congregação das Filhas de Jesus em Salamanca, com o objetivo de "caminhar ao encontro das maiores necessidades" e "para a educação cristã de todas as classes sociais". Padre Herranz, co-fundador da Ordem das Filhas de Jesus escreveu que "as que aqui estão, são para ensinar as internas e externas, ricas e pobres, aqui e ali, onde haja maior glória de Deus, pois é seu lema”. Imbuídos desse espírito inauguraram em $1^{\circ}$ de janeiro de 1874 o seu primeiro colégio (TOMERO, 1990:61-62)

Madre Cândida tinha o desafio de desenvolver um trabalho educativo numa sociedade que havia banido a religiosidade, sendo os pobres, em particular, afastados de qualquer instituição religiosa, enquanto que os de classe social mais rica tinham uma religiosidade, segundo ela, mais como um modo de expressão exterior do que oriundo de convicções íntimas. "Estávamos diante de um processo de paganização dos costumes", dizia Tomero (1990:87), claro que sob os auspícios do Espírito Iluminista, porém, no que diz respeito à educação e ao ensino, a sociedade espanhola excluía a mulher e as classes mais pobres do acesso às escolas. Até 1860, segundo Tomero, $86 \%$ das crianças do sexo feminino não sabiam ler nem escrever. E ainda assim havia uma distinção entre instruir e educar. Instruir 
significava oferecer um ensino mais ligado à prática e ao artesanato dirigido às mulheres de classe mais baixa, enquanto educar era para as moças da classe alta para que aprendessem a se comportar adequadamente na sociedade. Tinham acesso a noções rudimentares de leitura e escrita e uma base em gramática, literatura, etc.

Além da escola, havia na Casa da Concórdia, a escola dominical que atendia às domésticas de Salamanca.

Em 1877, Madre Cândida foi orientada a ir a Madrid para aprender métodos e práticas pedagógicas com as Irmãs da Assunção no Real Colégio de Santa Isabel. O governo espanhol, como ocorreu em muitos países da Europa, a partir de 1848, introduziu uma série de exigências de formação no ensino, destinadas a reduzir a influência da Igreja. Em 1854 foram suprimidos diversos mosteiros e conventos com exceção das ordens destinadas aos cuidados dos doentes ou ao ensino. Em 1883, a Congregação passou a enviar as irmãs para a Escola Normal Oficial a fim de obterem o diploma de mestras e, desse modo, terem acesso ao diploma oficial para afastar qualquer risco de serem excluídas do sistema de ensino e ficarem impedidas de levar adiante sua missão educativa.

\subsection{2 - A expansão}

As Filhas de Jesus tinham como prioridade a educação católica dos povos, dedicandose especialmente aos menos favorecidos. As irmãs estavam prontas a ir a qualquer parte do mundo, imbuídas dessa missão educativa.

Com 28 anos de fundação, trabalhavam no ensino em Salamanca e em mais oito povoações. Em 18 de julho de 1899, receberam, finalmente, um certificado com a aprovação governamental.

Em 1900, Madre Cândida Maria de Jesus buscou a aprovação das Constituições - o estatuto e regimento das Irmãs Filhas de Jesus - em Roma, uma vez que as aprovadas pela Santa Sé eram mais respeitadas pelo Governo Espanhol. Sua intenção era evitar serem alvo do movimento anticlerical manifestado em Madrid, que vinha praticando apedrejamentos de conventos. Em 25 de junho de 1901, o Decreto de Aprovação Pontifícia do Instituto foi assinado pelo Papa Leão XIII, e a Instituição deixava de ser de direito diocesano e passava a ser de direito pontifício. 
Em 24 de setembro de 1903, a ordem das religiosas contava com 42 irmãs Filhas de Jesus e tinham 10 casas, todas na Espanha. Em 1910, é aprovada a Lei do Candado ${ }^{23}$ que estabelecia a proibição de se fundar novas ordens religiosas na Espanha e as já existentes foram proibidas de abrir novas casas sem a autorização prévia do governo. Madre Cândida conta em seu diário, que desde 1908 tinha um convite do Padre espanhol Bruno Alberdi Zugadi, que estava a serviço no Brasil para abrir um colégio feminino em Pirenópolis, no estado de Goiás. A religiosa, desejosa de expandir sua missão apostólica, e pressionada pelo rumo dos acontecimentos anti - religiosos em seu país, aceitou o convite em 27 de dezembro de 1910. Essa expansão também parece ter servido de refúgio para as irmãs se abrigarem da revolução civil (1936) promovida pelos generais "nacionalistas" contra o governo republicano que se anunciava na Espanha. Conforme o livro escrito pela irmã Beatriz Macarro Castro (1987), no qual narra a história da congregação, no dia 3 de outubro de 1911, seis irmãs partiram para o Brasil, sem conhecerem a língua, o clima, a cultura, o povo, a geografia, tudo enfim, sendo sua primeira missão no exterior.

Só para se ter uma idéia das dificuldades de locomoção da época, a chegada ao Brasil, no porto de Santos ocorreu em 18 de outubro de 1911, quinze dias depois da partida das religiosas da Espanha. Elas foram de trem para São Paulo e de lá para Campinas, onde seguiram de trem para Araguari numa viagem com duração de três dias e meio. De balsa atravessaram o rio Paranaíba, e a pé chegaram ao Posto Anhanguera. O resto da viagem foi feito a cavalo, passando por Santa Cruz, Bonfim e Antas, hoje Anápolis. À noite dormiam em fazendas até conseguirem chegar a Pirenópolis, cidade às margens do rio Araguaia, a cidade mais importante do estado de Goiás naquele tempo.

Menos de um ano após a expansão apostólica além-mar, sem ter vindo ao Brasil, morria em Salamanca, dia 9 de agosto de 1912, Madre Cândida Maria de Jesus, deixando um projeto educacional que se espalhou por 15 países, sendo sete na América Latina.

\footnotetext{
${ }^{23}$ O nome de Ley del candado ("lei do cadeado") foi o termo aplicado a uma lei promulgada pelo ministro espanhol, Canalejas (1910-1912), em 1910, em nome do rei Alfonso XIII que proibia o estabelecimento de novas congregações religiosas na Espanha, limitando assim entre outros, o poder da Igreja sobre o Estado.
} 
No Brasil, a Congregação abriu 12 colégios, sendo que no Rio de Janeiro foi instalado no bairro do Leblon. Foi um começo difícil pela proibição de se abrir um colégio onde houvesse outra ordem religiosa, restando os bairros de Ipanema, Leblon ou Gávea. No entanto, nenhum destes bairros oferecia condições físicas razoáveis para abrigar um colégio porque havia um impedimento legal e só autorizavam um colégio confessional por bairro.

As irmãs queriam a abertura desse colégio porque a cidade do Rio de Janeiro era a capital do país, sede da Nunciatura Apostólica e do Ministério da Educação e Cultura. Contava com uma universidade facilitadora para a formação das religiosas, além de ser uma cidade portuária, com trânsito de navios para a Europa. Assim em 1935, dia 27 de fevereiro, inauguraram o Colégio das Filhas de Jesus no Leblon e 20 anos depois, compraram um colégio hipotecado na Avenida Niemeyer que passou a se chamar colégio Stella Maris para atender à classe média carioca. Iniciou como internato feminino, depois passou a ser colégio em regime semi-interno para alunas internas e externas, e misto a partir de 1980.

A cidade do Rio de Janeiro mudou muito desde a chegada da Congregação Filhas de Jesus no Brasil. A capital passou para Brasília (1960), a cidade se expandiu para os bairros da Barra da Tijuca e Recreio dos Bandeirantes, levando muitas escolas religiosas a lá instalarem suas filiais atendendo as classes média e média-alta. As comunidades do Vidigal e da Chácara do Céu, por sua vez, foram de tal maneira crescendo e se aproximando dos muros do colégio, que terminaram por impor sua presença à escola que fôra destinada originalmente às classes altas.

No inicio dos anos 90, a direção religiosa das irmãs Filhas de Jesus realizou uma assembléia de avaliação do plano pedagógico do seu colégio e constatou uma série de problemas em conseqüência das circunstâncias descritas abaixo:

- Nos últimos anos, seja pela localização, seja pela concorrência, notava-se progressiva diminuição na demanda de vagas. Ao mesmo tempo em que diminuía o número de alunos, reduzia-se também o número de Religiosas da Congregação.

- O colégio tornava-se progressivamente deficitário, em virtude da significativa diminuição do número de alunos. Tal situação muito provavelmente se agravou tanto pela dificuldade de acesso - pois a Avenida Niemeyer, onde o colégio está situado, tornou-se lugar de passagem - quanto pelo desenvolvimento do bairro da Barra da Tijuca com abertura de várias escolas, que se tornaram, frente àquela, concorrentes. 
- Pela impossibilidade de conferir outra finalidade para o prédio por se tratar de uma entidade filantrópica. Além de tudo, ampliava-se consideravelmente o percentual de famílias inadimplentes em relação ao pagamento das taxas escolares, como conseqüência da diminuição da renda familiar da população que acorria à Instituição.

- Ao mesmo tempo, uma antiga diretora do colégio, desejava, em razão de uma inquietação pessoal, elaborar um projeto dedicado ao atendimento das camadas populares, retomando o caminho inicial da Congregação de ir ao encontro da população de baixa renda. Essa Irmã - representante legal da instituição - vendo a comunidade da Favela do Vidigal passar diariamente por seus portões, com necessidade de se deslocar para ter acesso a escolas da periferia, defrontava-se com a contradição entre o que via, ou seja, aqueles meninos pobres que disputavam vagas em escolas distantes, e a existência de vagas ociosas no colégio.

- Em 1994, a escola, numa tentativa de superar a crise e para atender às famílias cujos pais trabalhavam o dia todo, optou por oferecer estudo em tempo integral, todos os dias ou, ao menos, alguns dias da semana. Essa opção revelou-se financeiramente onerosa e, por motivos vários, houve pequena adesão das famílias.

- Finalmente, em 1998 observou-se o auge da crise e a congregação começou a reorientar radicalmente seu rumo. A liderança das irmãs Filhas de Jesus baseada em um documento que resultou de uma Assembléia (dez / 98), de acordo com o qual, "no desejo de um pluralismo de opções educativas, acreditando nas tentativas que a Congregação tem feito de atender às diversas demandas percebidas, a saber: os apelos respondidos através do número significativo de comunidades de inserção em meios pobres, através de escolas de padrão alto; e também de escolas que respondem ao apelo das classes menos favorecidas" constatava que havia na vizinhança uma oportunidade de atender de maneira mais incisiva às necessidades educacionais da população infantil e juvenil da Favela do Vidigal.

- Através de dados do IBGE do ano 2000 soube-se que a população da favela do Vidigal era de 13.719 habitantes, com baixíssimo índice de escolaridade e elevada taxa de analfabetismo.

- A escola já anteriormente assumira vários serviços assistenciais prestados à comunidade circunvizinha tais como cursos profissionalizantes visando à geração de empregos (informática, arte culinária, treinamentos em serviço), ou cursos que dessem oportunidade de emprego em curto prazo, como curso de formação de professores em serviço ou de treinamento em serviço. Havia também serviços pastorais, como: catequese, crisma e culto dominical. Atendiam ainda a comunidade, promovendo encontro de casais e grupo de alcoólicos anônimos. O colégio cedia suas dependências para dois grupos de esportes da favela do Vidigal, duas vezes por semana à noite e havia o curso de alfabetização de adultos. A congregação referenciada nesses serviços 
decidiu transformar o então Instituto Educacional Stella Maris em um "Centro Popular de Educação e Assistência Social”, reorientando totalmente os seus objetivos para o atendimento dessa população.

Os resultados positivos e os frutos colhidos nesses encontros, aliados à demanda da comunidade $^{24}$ em busca de uma escola de qualidade, encorajaram a equipe a ampliar o acesso a outros alunos, assumindo um compromisso maior com as necessidades dessa população. Para tanto, a Direção das Filhas de Jesus contratou duas profissionais para fazer a sondagem das expectativas sociais e pedagógicas da comunidade. Essa dupla foi composta pela Diretora do Centro Popular, uma assistente social leiga e pela Diretora da escola. As duas elaboraram o projeto que, depois de aprovado, foi implantado no ano 2000 com a mudança jurídica da própria nomenclatura da escola, que de Colégio Stella Maris passou a chamar-se Instituto Educacional Stella Maris - Centro Popular de Educação e Assistência Social. A congregação teve como opção atender prioritariamente as comunidades da Favela do Vidigal e da Chácara do Céu com o objetivo de lhes propiciar uma escolaridade de boa qualidade, começando pela Educação Infantil e gradativamente estendendo ao Ensino Fundamental.

Assim, em 2000, a Instituição encampou a mudança de Instituto Educacional Stella Maris para Centro Popular Stella Maris.

\subsection{3 - A história das favelas}

A formação e a expansão dos núcleos de favelados, ou seja, a favelização da cidade do Rio de Janeiro teve seu marco inicial na virada do século XIX para o XX e ao longo do século XX com duas grandes transformações institucionais: a abolição da escravidão (lei áurea de 1888) e a recém proclamada República (1889) na então capital federal.

Três obras lançadas no final de 2005 desmitificam a visão folclórica segundo a qual o surgimento das favelas foi conseqüência de atos isolados e pontuais. Para Campos $(2005)^{25}$; Pereira da Silva, $(2005)^{26}$; e, Souza e Silva \& Barbosa, $(2005)^{27}$ o surgimento das favelas não

\footnotetext{
${ }^{24}$ Estudo das características sócio-econômicas e aspirações dos moradores da comunidade, realizado em julho de 1999.

${ }^{25}$ Para Campos (2005) além da exclusão social, havia a exclusão étnica que lançava os descendentes de escravos para habitações ilegais.

${ }^{26}$ Pereira da Silva (2005) relaciona o período de maior crescimento da população favelada carioca e o crescimento sem planejamento urbano do Rio de Janeiro.
} 
foi em decorrência de uma política higienista (final do século XIX) em busca da contenção das epidemias que assolavam a cidade que apontavam a lotação de casas sem a mínima infraestrutura como principais focos da sua expansão (favelas sempre vistas como local perigoso, seja pela violência da doença e seja pela do narcotráfico); nem como consequiência da derrubada em 1893 do maior cortiço da cidade do Rio de Janeiro, o ‘Cabeça de Porco’ que foi destruído da noite para o dia; nem a volta dos soldados que fizeram parte da Guerra do Paraguai (1864-1870) e/ou da Guerra dos Canudos (1896-1897) e se instalaram em habitações precárias no Morro da Providência por não terem lugar aonde morar; e, nem mesmo a reforma urbana feita por Pereira Passos, prefeito da capital federal entre 1903-1906 que modernizou o porto, abriu a avenida Central, alargou avenidas e desmontou cortiços para construir a avenida Beira-Mar; cuja conseqüência foi os pobres ficarem sem moradia e se instalarem com seus barracos nos bairros de Copacabana e Botafogo.

Todos os três autores contextualizam a história da favela carioca dentro de um processo mais abrangente inserido em um projeto de desenvolvimento de um país excludente e voltado para os interesses das classes dominantes. Descobre-se também que o êxodo rural, a industrialização e a migração para os grandes centros urbanos são marcos importantes nessa história, que trouxe suas raízes do descaso público - imperial ou republicano, democrático ou autoritário - com os problemas das camadas populares. Desde a abolição da escravatura já não havia uma política que solucionasse o problema do negro, que livre não tinha a oportunidade de emprego, proibidos de possuir propriedades rurais, de exercer qualquer cargo público e sem acesso à educação. "Excluídos na sociedade, não podiam morar nos espaços formais da cidade e buscavam abrigo em zonas marginais em busca de sua sobrevivência" $\left(\right.$ SAMPAIO, 2006) ${ }^{28}$.

Segundo o estudo realizado por Tepedino (2007) a história da favela do Vidigal começa no primeiro Império (1822-1831) com um Major de milícias chamado Miguel Nunes Vidigal que recebeu de presente dos monges beneditinos (por volta de 1820) uma grande extensão de terra aos pés do Morro Dois Irmãos. Essa propriedade foi comprada pelo engenheiro João Dantas para a construção de uma linha de ferro que atendesse o litoral sulfluminense e que não foi adiante mas serviu de base para a construção da avenida Niemeyer, que liga os bairros do Leblon e São Conrado.

\footnotetext{
27 Souza e Silva \& Barbosa (2005) levantam dados para compreender a história da visão estereotipada e preconceituosa da favela como espaço do caos habitada por miseráveis, e analisam a complexidade do sistema de favelas em busca de soluções alternativas para um planejamento de urbanização de favelas.

${ }^{28}$ www.reportersocial.com.br, acessado em 21/1/2006.
} 
A ocupação do morro começou em 1941 com a construção de barracos na parte mais baixa do morro, no costão da pedra próximos ao mar. Em 1950, os primeiros moradores foram removidos para a parte situada acima da avenida Niemeyer, dando origem à favela do Vidigal e da Chácara do Céu, tal qual as conhecemos e que teve uma explosão demográfica na década de 50 e 60. Apesar das várias investidas para sua remoção, a Associação de Moradores do Vidigal foi criada em 1967 e sempre agiu energicamente, mas de maneira legal, junto à prefeitura, com o apoio da Pastoral de Favelas da Igreja Católica. Hoje em dia a comunidade do Vidigal integra o programa Favela-Bairro, proposta da Prefeitura da cidade do Rio de Janeiro para integrar a favela à cidade formal, com acesso aos serviços urbanos, como cidadãos da cidade. 


\section{CAPÍTULO 3: A CIVILIZAÇÃO ESCOLAR E AS CAMADAS POPULARES}

\subsection{A civilização escolar e as camadas populares}

Consideramos que a escola cumpre uma função civilizatória por ser uma instância social, universal, apropriada para a instrução e formação coletiva de crianças, jovens e adultos, de todas as classes sociais. Indagamo-nos, entretanto, sobre a adequação da função civilizatória da escola e qual o recorte que essa escola fez e faz da cultura para distinguir as novas (ou não) maneiras de lidar com a formação de crianças oriundas das camadas populares.

Cultura e civilização são termos que muitas vezes se confundem, sendo tomados, muitas vezes, como sinônimos. Podemos pensar a civilização de forma mais abrangente que a cultura. A civilização prevê e abriga a enorme diversidade cultural da espécie humana. A importância de se estudar a cultura deve-se à capacidade humana de gerar símbolos e significados que os objetos recebem de cada cultura partilhados por seus membros.

Nesse sentido, perguntamo-nos se a formação dada pela escola envolveria a transmissão de cultura no interior de um processo civilizatório, no sentido de envolver questões de atitudes, ao mesmo tempo que transmite conhecimentos?

Como assinala Thin (2006), a forma escolar de socialização se passa intra-muros, isto é, fora da vida social comum, com as crianças longe do seu mundo familiar e separadas por faixa etária. A instituição escolar caracteriza-se por ter espaço e tempo específicos, que acontecem unicamente na escola, imprimindo seus ritmos próprios e deixando um tempo mínimo livre de atividade educativa para o lazer. Segundo as palavras de Thin: "Por meio das aprendizagens desenvolve-se um trabalho educativo e moral" (Thin, 2006:216).

Barbosa (2007), a esse respeito, considera que a escola veicula a idéia de ser a 'única' instituição educativa e que os conhecimentos por ela transmitidos seriam os únicos legítimos, como uma estratégia do poder que "visa legitimar um tipo de conhecimento, considerado legítimo ou oficial, em detrimento de outros, os populares, desqualificando assim outras formas de cultura e de estilos de vida". Nesse sentido, a autora observa que a "escolarização também pode ser analisada como um processo de 'colonização' pela qual passarão, obrigatoriamente, as crianças - de todas as classes sociais - e as pessoas adultas das classes populares para poderem pertencer ao mundo industrializado" (BARBOSA, 2007:1061). A escola amplamente reconhecida como a única instituição da modernidade freqüentada por 
todos, crianças e jovens, tem um poder inegável formando uma sociedade escolarizada, a qual segundo Lahire (2006), influencia as práticas culturais da vida adulta.

Nossa interrogação é em torno exatamente desse papel da escola na transmissão da cultura, ou mesmo da civilização escolar, que pode ser traduzida pela "arte de transformar crianças/adolescentes em alunos", que sempre envolveu questões disciplinadoras.

A moderna civilização escolar, já sem castigos físicos, adota práticas de ensino semelhantes às do passado, uma vez baseadas em deveres, punições e recompensas, posturas e gestos que constituem os ritos do processo pedagógico. Desde o final do século XVI, segundo Boto, os alunos são:

[...] repartidos por séries, os escolares trabalhariam a temporalidade de uma vida recortada por horários. Em cada horário, um campo do saber. Em cada disciplina, um olhar permitido. Os compêndios escolares eram apresentados como veículos de saberes. O professor deveria dar sua aula falando a todos os alunos de uma só vez (...) dirigida a todos os sujeitos sociais e regulada mediante rígidas ordenações de conduta, que falam tanto por suas vozes quanto por seus emblemas e sinais. Daí a padronização ritual do principal sistema de formação da modernidade ocidental: a escola (BOTO, 2007a:41)

E qual o patrimônio cultural que a escola passa para seus alunos?

A partir dos estudos de Forquin (1993), analisaremos qual é o papel da escola e sua grade curricular na formação dessa clientela. Segundo ele, curriculum em inglês designa não só uma categoria de objetos pertencentes à esfera educativa tais como os programas escolares, mas também uma abordagem global dos fenômenos educativos, uma maneira de pensar a educação, que consiste em privilegiar a questão dos conteúdos e a forma como estes conteúdos se organizam nos cursos.

Fizemos nossa investigação na escola tendo como elemento norteador a seguinte preocupação do autor, procurando refletir sobre: "o que acontece realmente aos alunos, no plano cognitivo, mas também no plano afetivo e social, devido ao ensino que eles recebem e a sua experiência de escolarização (...) o que acontece objetivamente ao aluno como resultado da escolarização enquanto experiência vivida?" (FORQUIN, 1993:23)

Ora, o currículo engloba um programa de formação, um plano de estudos. Neste programa se expressa a cultura através de saberes, que contemplam tanto a instrução, como a formação de hábitos e atitudes. 


\subsection{1 - Aspectos civilizatórios da escola}

A formação de hábitos e atitudes se dá pelo comportamento esperado do aluno, num ritual de organização, onde há códigos de conduta manifestos e latentes. Espera-se dos alunos a aquisição de valores, hábitos de civilidade e de racionalização. As classes são divididas homogeneamente. O mesmo ritmo é esperado de todos e o tempo também é vivido na escola, graduada por séries e idades, pelos exames regulares, pelo relógio que marca o tempo da aula e do recreio. Há também o tempo do professor versus o tempo do aluno, e ainda o tempo da administração escolar com suas normas para o calendário escolar, conforme observara Boto (2003).

A disciplina, como comportamento, é exercitada através do ato de vigiar, de corrigir, da submissão à autoridade e do reconhecimento da hierarquia. Mesmo nas normas do texto escrito isto é vivido, pois há uma gramática estabelecida pela cultura que serve como organizadora dos textos.

E o espaço? Tanto pode ser representado pelos lugares na sala da classe, como a arquitetura da escola e sua localização.

Diferentes interpretações podem ser dadas aos comportamentos dos alunos, por exemplo, em um mesmo espaço - a escola - a depender da ótica de cada um dos envolvidos. Se do ponto de vista do aluno, ele "cabula, cola, não denuncia o colega", do ponto de vista do professor, o aluno "falta, transgride e se omite"! Nesse processo, há a exposição do professor, ao mesmo tempo, que, a exposição do aluno. A escola, é sobretudo, campo de relações: do professor com o aluno, com o funcionário, com os colegas, com a comunidade, com as famílias e do aluno com o professor, com outros alunos, com os funcionários, com outras famílias, com a comunidade.

Forquin (1993) assinala que as mudanças técnicas e tecnológicas tornaram nossa cultura mais dependente da escrita, tornando-se necessária para o acesso aos recursos e às formas de expressão, característicos da tradição escrita. A partir de 1960, vivemos em um mundo profundamente marcado por importantes mudanças sociais e profundas mutações culturais, bem como por grandes transformações no interior do mundo da escola (prolongamento da escolaridade obrigatória, aumento do número de pessoas escolarizadas, acolhida de alunos sem seleção nem discriminação, renovação dos conteúdos, dos métodos do ensino e do corpo docente). Ao mesmo tempo, convivemos com fatores determinantes extra- 
escolares da educação escolar como a família e o contexto social que assumem um papel educativo nunca dantes exercido, com a exposição dos alunos aos meios de comunicação.

Bantock (1968) se opõe à corrente da via da escolarização obrigatória que há cento e cinqüenta anos se impõe. Para ele até o surgimento da industrialização na Inglaterra, no final do século XVIII, era possível distinguir duas grandes áreas culturais. Existia a cultura da classe alta baseada em sua capacidade da leitura e da escrita e a cultura da gente comum, cultura do povo, cultura popular alicerçada na tradição oral. Nessa época, a cultura popular possuía mérito artístico e grande vigor através da excelência de seu artesanato, cantos, danças, contos que vinham da tradição rural de muito tempo. Essas manifestações permitiam ao povo enfrentar corajosamente, até com alegria, a dureza do seu contexto e de sua situação econômica. Havia uma grande variedade de pessoas talentosas, que para Bantock era conseqüência de não existir um sistema de educação produtor de uma estratificação social fundamentada na capacidade. $\mathrm{O}$ artista rural integrava-se com o que recebia do seu meio.

As mudanças ocasionadas pela revolução industrial e consequiente urbanização significaram a destruição de antigas formas comunitárias de se relacionar, com a tradição e cultura, inclusive. O lado positivo da cultura popular, diz Bantock, se dá por sua relativa estabilidade; sua força moral deriva deste "enraizamento" e seu lado negativo é a estreiteza de horizontes - sejam intelectuais, sejam emocionais - que lhes nega a "emancipação" que pode proporcionar saber ler e escrever. O desenvolvimento do racionalismo científico junto com o progresso técnico diminuiu a relativa estabilidade das culturas pré-industriais assim como o liberalismo e o romantismo, pois ambos reafirmavam o indivíduo, seus direitos e aspirações a uma cultura universal, contra a herança comum da antiga tradição popular.

Bantock discorreu sobre a questão do trabalho no período anterior à Revolução Industrial e constatou que se trabalhava em condições, muitas vezes precárias, porém boa parte dessas tarefas tinham objetivos muito mais variados do que na atualidade. No seu entender, o homem sentia-se parte do processo e do produto do trabalho. Seus instrumentos, na sua maioria manuais, impunham à obra o próprio ritmo humano (BANTOCK, 1971:19). O operário podia ver o resultado do seu esforço no produto final de seu trabalho, que levava sua marca pessoal e pelo qual se sentia responsável. Um meio ambiente deste tipo produzia um tipo de educação que, segundo Bantock, talvez suscitasse harmonias inconscientes geradas mais pela atuação pessoal do que por um processo de conhecimento consciente.

Com o advento da revolução industrial, observa o autor, o trabalhador se viu separado entre o lugar onde habitava e seu trabalho, introduzindo a tirania do relógio, que impôs 
modificações profundas nos ritmos da existência humana e no modo de viver suas relações sociais. Thompson sintetiza essa fase: "muitas horas de trabalho insatisfatório sob uma disciplina severa e com objetivos alheios" (Thompson, IN: BANTOCK, 1971:21).

Tudo isso teve incidências sobre a cultura popular, pois boa parte desta surgira do trabalho e das relações que este promovia. Para Bantock o funcionamento da máquina, por exigir tão pouco do operário, contribuiu para a manifestação da apatia, levando o operário a reduzir suas exigências culturais e a contentar-se com poucas satisfações que não provocassem uma grande tensão entre sua vida de trabalho e o descanso. Para ele "a própria consciência mítica dos trabalhadores se converteu em presa de trivialidades, infladas e vazias" (BANTOCK: 1971:25) ${ }^{29}$. E mais, as mudanças sociais, econômicas e políticas suscitadas no século XIX, forçaram a sociedade a realizar um experimento único na história da humanidade: a instauração de um sistema de educação cujo objetivo era a alfabetização universal como parte do movimento da escola obrigatória. Para Bantock essa idéia de educação universal foi um erro cultural de profundo significado por confundir a cultura da comunicação com a alfabetização, o que contribuiu para o declínio da tradição oral, passada de geração em geração, e a valorização da cultura da classe alta, que passou a ser vista como a representante da Cultura.

Entre os fatores determinantes do estabelecimento do currículo e rituais da escola elementar foi a necessidade de disciplinar a mente para oferecer aos alunos um pouco de cultura, cultura essa que, do ponto de vista das classes educadas, desconhecia por completo o novo ser humano que, por obrigação, foi às escolas impondo-lhes uma cultura "estranha e sem sentido para ele" (BANTOCK, 1971:28). A pedra fundamental da cultura escolar se encontra na frase ritual que serve como introdução à maioria das lições na escola: - "Peguem seus livros".

Bantock propõe uma educação que promova a libertação do indivíduo; e não sua submissão. Posiciona-se contrariamente à idéia de subjugar, cada vez por mais tempo, massas de alunos a tipos de educação cada vez mais uniformes. Nesse sentido, opõe-se a toda política educativa que exige esta uniformidade em nome da igualdade de oportunidades e da democratização cultural, pois considera este conceito de igualdade de oportunidades bastante ambíguo. Ele concorda em parte com a idéia da igualdade do "ponto de partida", de uma igualdade nas possibilidades de escolarização legalmente concedidas a todos os cidadãos de um mesmo país, embora a considere muito mais como um "direito igual a todos para

\footnotetext{
${ }^{29}$ La propia conciencia mítica del trabajador se convirtió en presa de trivialidades, infladas y vacía.
} 
tornarem-se desiguais". No entanto, o que se confere aos cidadãos é uma uniformidade nos cursos ou uma equalização nos resultados, que não se pode tratar, segundo ele, senão como expressão de uma utopia socialmente perigosa e culturalmente desastrosa, já que os indivíduos são desigualmente "aptos" para se beneficiarem dos recursos educativos. Por fim, para Bantock, toda educação é em essência "desequalizadora", assumindo, portanto, uma posição semelhante à sustentada por Dubet (2004).

Bantock considera que a cultura escrita propicia o individualismo, o racionalismo, a "intro-determinação", o enfraquecimento dos laços de participação comunitária, a erosão da consciência mítica. Sustenta, ainda, que a escolarização de massa, que se erigiu no século XIX, "sobre as ruínas da velha cultura oral e comunitária, destruída pela revolução industrial e urbana" (1968), outorgou-se como tarefa a difusão do acesso a uma cultura até então restrita a uma minoria de intelectuais como clérigos e letrados. No entanto, não se avaliou talvez suficientemente, calcula Bantock, a complexidade desta experiência histórica sem precedentes.

$\mathrm{O}$ autor, assumindo um ponto de vista interessante e, no entanto polêmico, pondera que:

[...] o projeto 'democrático' de fazer aceder todo mundo à cultura alfabética e erudita carrega em si uma contradição insuperável: a prática constante da leitura e da escrita supõe uma extraordinária ascese cognitiva (grifo nosso) ${ }^{30}$, que poderia muito bem se revelar insuportável para a maioria dos indivíduos. $\mathrm{Na}$ verdade, o alfabetismo supõe um tipo de relação com os seres e as coisas que está em total oposição com aquilo que constitui a orientação cognitiva espontânea desta maioria e constitui para ela uma ameaça grave de destruição da identidade (Bantock, in FORQUIN, 1993: 44).

Bantock sublinha, nesse sentido, que:

“O Dionísio nietzcheniano, o deus do instinto e da festa, morre a cada dia nas
escolas, sufocado por Sócrates, o 'homem teórico'. Desde há cento e cinquienta anos,
a escola oferece assim às massas um substituto e um remédio e aniquila a velha
cultura oral e comunitária. Apregoa que o alfabetismo e a cultura escrita podem
aparecer como uma conquista popular e como uma aquisição histórica irreversível,
mas sua adesão não podia, entretanto, efetuar-se de modo massivo, profundo e
durável. Uma vez adquiridas - ao preço de grandes dificuldades - as competências
mínimas em leitura e em escrita, constata-se atualmente que numerosos alunos são
incapazes de responder às solicitações e às exigências profundas da cultura
alfabética. E desde que a tecnologia permitiu o advento de meios de comunicação

${ }^{30}$ Ascese = na filosofia grega, conjunto de práticas e disciplinas caracterizadas pela autoridade e autocontrole do corpo e do espírito, que acompanham e fortalecem a especulação teórica em busca da verdade (Houaiss dicionário de língua portuguesa) 
que não se apóiam sobre o impresso, uma nova cultura expandiu-se irresistivelmente, mais sedutora, mais estimulante, mais pertinente em relação às necessidades afetivas e às possibilidades cognitivas das massas, que Bantock qualifica de 'pós-alfabética'” (Bantock, in FORQUIN, 1993:44)

Forquin (1993) alerta sobre o sentido do mundo dos meios de comunicação, considerando-o em grande parte "um mundo de simulacros" pois, segundo ele, este mundo de imagens com os quais convivemos servem para nos alienarmos de nós mesmos. Compreende que as massas preferem:

[...] o sensacional, o exótico, o misterioso, a uma abordagem racional e analítica da realidade. E o homem procurou sempre projetar suas esperanças e seus medos através dos mitos, formas narrativas poderosamente estruturadas capazes de canalizar as emoções cristalizando as crenças coletivas. Contudo, as grandes mitologias geradoras de sentido - e singularmente o mito cristão - perderam sua credibilidade devido ao progresso do racionalismo. Para as massas modernas afetivamente incapazes de suportar a angústia consecutiva à destruição do sentido mítico do mundo e ameaçadas pelo nihilismo, os novos meios de comunicação industrial são chamados assim, em particular através das mensagens publicitárias, a fornecer uma mitologia de substituição. Mas, para Bantock, trata-se na verdade de uma mitologia de miséria, de uma mitologia sem valor, que não expressa mais as verdades humanas profundas, os dilemas fundamentais, mas sim os sonhos fúteis, os estereótipos triviais, as necessidades pré-fabricadas de uma humanidade medíocre e mal educada, habituada a ver não importa que desejos superficiais satisfeitos sem esforços. Assim nossa cultura popular moderna propõe às massas desorientadas todos os substitutos possíveis do sonho romântico sem limites. Ela oferece a bom preço, cotidianamente, a milhões de desenraizados, dezenas de vidas excitantes para viver por procuração, e a promessa de uma identificação fácil com toda sorte de heróis momentâneos. Daí a instabilidade emocional dos consumidores da cultura de massa, a diversidade dos estilos de vida nos quais eles são capazes de se projetarem simultaneamente ou sucessivamente, e também a valorização insistente, em nossa sociedade, das virtudes da flexibilidade, da adaptabilidade, da labilidade como resposta ao renovamento perpétuo das formas sociais e culturais. (FORQUIN, 1993:44-45)

Enquanto a escola é voltada para o real, para a apreensão e o domínio do real - mesmo que ao preço de uma passagem pelo didatismo e pela abstração - a cultura, para Bantock, veiculada pelos meios de comunicação é profundamente e fatalmente anti-educativa por ressaltar, mesmo quando se propõe a fornecer alguma informação, o superficial, o fugaz, o momentâneo, favorecendo a dispersão da atenção. Ela veicula um imaginário artificial e mistificador, divulga uma abordagem 'consumista' da vida, uma moral do gozo imediato e permanente, do lazer e da diversão, incompatível com a seriedade envolvida na promoção do conhecimento:

[...] A cultura de massa é, adverte Bantock, anti-educativa, porque tende a fazer crer a cada um que ele pode ser o árbitro final do gosto e da moralidade, que nenhum 
indivíduo pode legislar em lugar de outro, que o espírito democrático é incompatível com o reconhecimento de verdades e de valores objetivos, que todas as ações e todas as expressões se equivalem, que toda noção de superioridade é um mal e que todo empreendimento de ensino é a priori suspeito de desejo de doutrinamento. (Bantock, In FORQUIN, 1993:45)

A escola, entretanto, é em grande parte responsável, aos olhos de Bantock, pela situação de crise cultural na qual se encontra atualmente mergulhada e alega que a escola não estaria assim se não fosse pelo fato de estar cega e obstinada em querer institucionalizar o evangelho igualitário, por querer transmitir a todos uma cultura alfabética e erudita, que não é, na verdade, compreensível e desejável a não ser para alguns, por querer escolarizar todo mundo igual e uniformemente, chocando-se com obstáculos culturais pedagogicamente insuperáveis. Para manter a ilusão da igualdade, a ilusão da mesma cultura para todos, resigna-se progressivamente a promover um "nivelamento geral", renuncia a fazer progredir os melhores conforme as suas possibilidades e as suas motivações profundas, continuando sempre a impor, aos outros, programas que eles rejeitam completamente. Perdem assim os dois lados. Colocando-se na impossibilidade de manter e de transmitir a herança essencial da alta cultura tradicional, sacrifica-se o futuro, sem propor, em troca, nada que, no presente, seja gerador de satisfação para quem quer que seja. Propõe, em contrapartida, uma política de diferenciação dos cursos, para públicos distintos (Bantock, In: FORQUIN, 1993:44-45).

Segundo Forquin, Bantock sustenta que:

[...] com efeito, é exatamente com relação a esta massa imensurável e compacta de alunos 'comuns' e 'médios` que menos sabemos hoje em dia o que é possível e desejável ensinar". (...) Diz que "muito freqüentemente também se trata de um problema de ordem cultural mais do que cognitivo: existe um conflito latente entre as orientações, as atitudes, os valores culturais que (aqueles alunos) devem ao seu meio familiar e social e as exigências implícitas da cultura escolar, pelo fato de que esta põe ênfase numa abordagem essencialmente intelectual e livresca do mundo (Bantock, In: FORQUIN, 1993, 1993:50).

O essencial da cultura, isto é, a maneira de viver, que não se aprende na escola, mas no seio da família e do meio social em que se está inserido. De fato, impor uma superescolarização ao indivíduo, é destruir sua identidade, pois este aprende hábitos e gostos característicos no interior de suas famílias e comunidade. A ênfase no papel da escola em detrimento da educação familiar pode ser causa de infelicidade, uma vez que, desprovida de raízes e memória cultural, dá margem a que surja um conflito latente entre as orientações em jogo: as atitudes, os valores culturais que o indivíduo traz de seu meio familiar e social, de um 
lado, e de outro, as exigências implícitas da cultura escolar, que enfatiza uma abordagem predominantemente intelectual e livresca.

Segundo Forquin (1993), Bantock destaca o risco dos efeitos maléficos que surgem na tensão entre a tradição letrada e livresca, no "levantamento de muralhas alfabéticas, o enclausuramento de gerações inteiras na fortaleza escolar" que não constituem uma resposta afirmativa diante da realidade deste desafio, ao contrário, faz com que o indivíduo sinta uma falta absoluta de resposta às suas inquietações, uma vez que não responde a seu vazio emocional. Nesse sentido, busca nas imagens de todos os dias, veiculadas pelos diversos meios de comunicação uma resposta que também não o satisfaz (FORQUIN, 1993:50). Para lidar com essas questões, é necessário que a escola tenha por meta não a submissão dos indivíduos e sim sua afirmação enquanto sujeitos pensantes. Que a imersão na cultura seja lugar de satisfação e sentido e não geradora de dificuldades e angústias. É preciso que o aluno perceba-se como leitor e escritor da realidade. Requer disponibilidade para aprender a olhar e romper com visões cegas, esvaziadas de significados. De acordo com Madalena Freire (2006), aprendemos porque damos significado à realidade, porque buscamos, desejamos saber o por quê do que não conhecemos. Toda busca de saber nasce de uma inquietação. Este é o principal desafio da Educação (informação verbal) ${ }^{31}$.

Buscamos tratar essas questões sobre a cultura escolar do ponto de vista de Forquin, Bantock e Madalena Freire para adentrarmos no cotidiano escolar refletindo sobre essas questões da diversidade cultural no desafio assumido por essa escola ao se abrir para receber alunos das camadas populares em uma escola tradicionalmente voltada para as classes médias e médias altas.

\footnotetext{
${ }^{31}$ Informação fornecida por Madalena Freire, em aula proferida no ISEPS (Instituto Superior de Educação PróSaber) em 2006.
} 


\section{Capítulo 4 - 0 COTIDIANO ESCOLAR PESQUISADO}

Conforme já mencionamos na introdução do presente trabalho, nosso foco de estudo foi observar, a partir do ingresso de uma nova clientela na escola pesquisada, o impacto causado nas relações pedagógicas entre professores e alunos, as aproximações e distâncias entre a cultura escolar e a cultura popular no cotidiano escolar (estabelecimentos de limites, regras e horários), as formas de ensinar (estratégias e recursos pedagógicos), e os conteúdos propostos nas disciplinas das $5^{\text {as }}$ e $6^{\text {as }}$ séries dessa instituição de ensino particular de tipo confessional, com o redirecionamento do seu projeto pedagógico para atender as populações faveladas da Chácara do Céu e do Vidigal.

\section{1 - Panorama escolar}

\subsection{1 - Localização Geográfica da Escola}

Figura 1 - Localização da escola em relação aos bairros

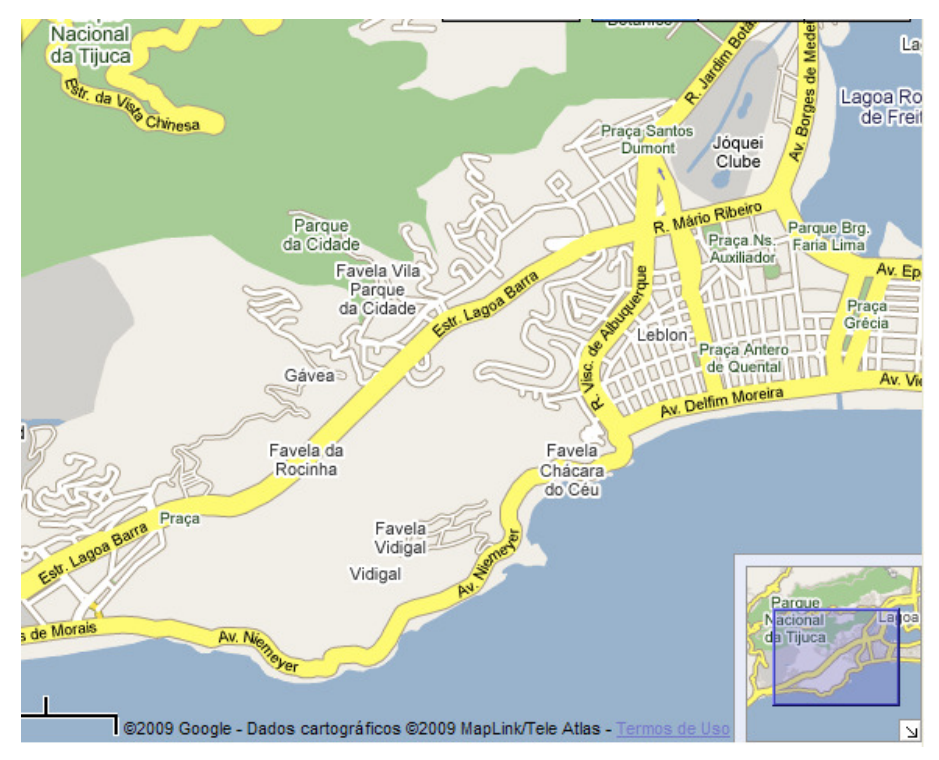

O Centro Popular de Educação e Assistência Social Stella Maris, antigo Instituto Educacional Stella Maris, situa-se no bairro do Vidigal, na cidade do Rio de Janeiro. Este bairro localiza-se entre a praia do Leblon e a praia de São Conrado, à beira do Morro Dois Irmãos. A vista é privilegiada, pois as casas, tanto de ricos como de pobres, sobem pela encosta do morro e tanto uns como outros podem usufruir a bela paisagem do mar e das praias do Leblon, Ipanema e mesmo do Arpoador. O colégio fica situado entre a encosta do 
morro e a Avenida Niemeyer, que faz a ligação entre os bairros do Leblon e São Conrado. É cercado, de um lado, por hotéis de luxo como o Sheraton e motéis menores que ficam na parte baixa do morro e, de outro, pelas comunidades do Vidigal e da Chácara do Céu. Embora esse contraste seja marcante, pode-se considerar como uma característica da cidade do Rio de Janeiro.

Os grandes centros urbanos de nosso país padecem de um mesmo mal: o imenso contraste da habitação de brasileiros, que vivem na mesma cidade, mas que se encontram mergulhados em duas realidades sócio-econômicas e, muitas vezes, culturais, opostas. Para Ortiz (1988), esse cenário é consequência do projeto de modernização brasileiro - restrito, incompleto, de 'fachada' - marcado por significativa defasagem entre a modernização que se pretendia no Brasil a partir da década de 20 e a realidade que saltava aos olhos, quando se observava a inexistência de condições materiais para o conjunto da população. Uma realidade observada desde os tempos coloniais, mesmo após a abolição e que assim se manteve até muito recentemente no Rio de Janeiro, marcada por um contraste imenso entre a realidade de primeiro mundo das avenidas ao longo das praias e a realidade dos morros, com sua miséria, falta de saneamento básico e de equipamentos sociais mínimos, e muita violência.

Essa 'pretensa' modernização foi bem discutida pela tradição intelectual que a nomeou de 'cultura ornamental ${ }^{32}$. Ortiz descreve o cenário da cidade no final da época colonial, cuja herança nefasta pode ser observada ainda hoje:

[...] A remodelação urbana da cidade, a valorização do chique europeu (Art Nouveau), o frenesi com que se vive a agitação dos novos tempos, o advento da eletricidade nas casas e nas ruas, são transformações vividas sob o signo do moderno por uma 'burguesia carioca que se adapta ao seu novo equipamento urbano, abandonando as varandas e os salões coloniais para expandir a sua sociabilidade pelas novas avenidas, praças, palácios e jardins'. Contrastando com esse retrato de otimismo temos a presença das favelas, o medo do impaludismo, o peso de uma herança colonial paupérrima que invade o cenário minando esta imagem tão cuidadosamente construída. (ORTIZ, 2006: 32)

As duas comunidades da Rocinha e da Chácara do Céu se entrelaçam entre casas muito simples, construídas com materiais precários, atravessadas por ruas estreitas, apertadas e repletas de camelôs, minimercados, motos, pedestres, crianças e adultos, velhos e moços,

\footnotetext{
${ }^{32}$ Ortiz entende por esse termo: "Sua ornamentalidade aponta para uma falsidade, a vontade da classe dominante de se perceber enquanto parte da humanidade ocidental avançada; a doutrina liberal se transforma assim em valor ostentatório, o que em princípio asseguraria o pertencimento da burguesia nacional aos ideais de civilização e acomodaria na consciência da classe dominante o atraso brasileiro em relação aos países centrais" (Ortiz, 2006:30)
} 
vans e kombis, carrinhos de compras e de crianças, ônibus que fazem a manobra nessas ruas, num padrão característico do ambiente de favelas, que aparecem da noite para o dia, sem um mínimo de planejamento e saneamento. No entanto, nessas duas comunidades já se observaram melhorias semelhantes ao restante da cidade que já conta com conforto, principalmente de infra-estrutura. Segundo dados do IPP $^{33}$, em 2000 havia 3.235 domicílios dos quais $79 \%$ eram imóveis próprios. Destes, 97,8\% eram abastecidos com água encanada (com funcionamento precário mas já instalado), e a rede de esgotos atingia 94,8\% dos domicílios. A coleta de lixo atendia $100 \%$ do Vidigal.

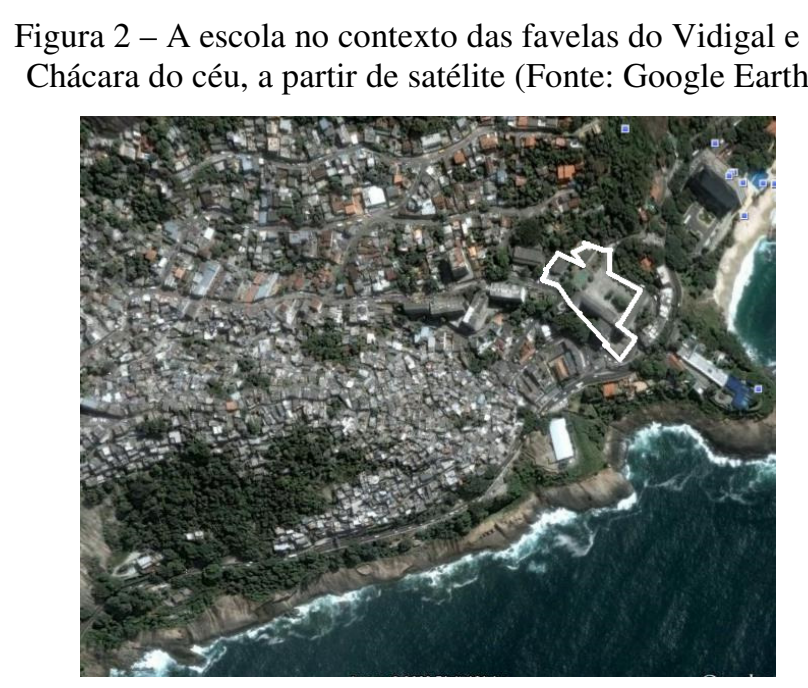

\subsection{2 - Descrição da escola}

De acordo com o Projeto do Centro Popular de Educação, o colégio possui seis mil metros quadrados e tem uma área construída, com quadras esportivas, pátios, auditório, laboratórios, biblioteca, capela, parques, jardins, cozinha, refeitório, sala de artes, sala de música, oficina de teatro e salas de aula. Os alunos pagam uma mensalidade reduzida (a título de bolsa) e, apesar de todas as dificuldades para a manutenção da instituição, não adotaram uma política de demissão dos funcionários; estes, na sua maioria, oriundos do Vidigal.

O colégio tem como objetivo a manutenção do padrão de qualidade no que se refere à educação de crianças e adolescentes da comunidade do Vidigal; considerando que estes são

\footnotetext{
${ }^{33}$ Instituto Pereira Passos
} 
direitos básicos e incontestáveis, conforme o previsto no Estatuto da Criança e do Adolescente $^{34}$.

São objetivos da instituição, conforme documento Projeto do Centro Popular de Educação 2000:

- Possibilitar às crianças da Comunidade do Vidigal uma educação de qualidade;

- Atender crianças e adolescentes, na sua formação básica, visando à aquisição e difusão do saber e do conhecimento;

- Atender jovens e adultos para a formação complementar e capacitação profissional;

- Formar cidadãos capazes de compreender a realidade social, conscientizá-los de seus direitos e responsabilidades, desenvolvendo-lhes os valores éticos; o aprendizado da participação e a educação para a democracia;

- Colaborar com o início da escolaridade (alfabetização) de adultos;

- Estimular a prática esportiva desenvolvendo atividades relacionadas com esporte e lazer;

- Aprimorar a formação dos pais, ajudando-os a exercerem melhor suas funções educativas.

\subsection{3 - Inscrição de alunos}

A procura para se matricular no colégio é bem grande, e as inscrições são feitas em duas a três semanas nas quais os alunos são informados sobre a data da avaliação. A criança para entrar para a Educação Infantil é avaliada por um processo de socialização que tem apenas o intuito de conhecê-la, "é um momento que a gente tem para conhecer e para as mães contarem um pouquinho da história das crianças". Depois as famílias são encaminhadas para fazer a ficha socioeconômica com a assistente social para estabelecer o pagamento de acordo com a renda familiar, conta-nos a responsável pela inscrição dos alunos.

A preferência é para a entrada de alunos procedentes de família de baixa renda (público de vulnerabilidade socioeconômica excluído pela pobreza) e moradores das favelas do Vidigal e da Chácara do Céu, por não precisarem pagar condução, o que lhes permite economizar para pagar a taxa mensal do colégio. "Se eles vêm de fora, eles pagam a condução e ficam sem recursos para pagar o colégio. Com isso evitamos o risco de estar

\footnotetext{
${ }^{34}$ Estatuto da criança e do adolescente. Lei no 8.069 , de 13 de julho de 1990 e Lei 8242 de 12 de outubro de 1991.
} 
colocando gente de fora, e a comunidade [refere-se às comunidades do Vidigal e Chácara do Céu] não ser atendida".

A maioria paga o colégio regularmente e os que ficam devendo "são os que estão devendo sempre". Com estes, a escola procura conversar para "fazer um acordo, dois, tantos quanto forem possíveis", segundo a responsável administrativa pela concessão das bolsas.

As mensalidades computadas em 2008 tiveram o seguinte valor:

- Educação Infantil até a 4a série do Ensino Fundamental: R\$374,00 (trezentos e setenta e quatro reais);

- $5^{\mathrm{a}}$ a $8^{\mathrm{a}}$ séries do Ensino fundamental: $\mathrm{R} \$ 599,00$ (quinhentos e noventa e nove reais).

Para o cálculo da tarifa escolar, é feito o levantamento do total das despesas da escola e a soma é dividida pelo número de alunos. O colégio complementa o custeio das despesas com recursos da Congregação, além de contar, a partir de 2007, com o patrocínio de seis empresas privadas. No entanto, como esclareceu Tepedino (2007), tais patrocínios eram destinados exclusivamente às atividades extra-curriculares como projeto de futebol, de vôlei, aulas de reforço e/ou passeios. Os reajustes nas mensalidades são concedidos pelo governo.

A coordenadora nos informou que o valor das bolsas é estabelecido mediante um estudo socioeconômico das famílias, baseado nos seguintes critérios:

\footnotetext{
- $\quad$ Renda per-capita;

- Número de pessoas na família;

- $\quad$ Número de dependentes estudando;

- Casa própria;

- $\quad$ Construção de casa própria;

- $\quad$ Financiamento da casa própria;

- Despesas com aluguel;

- Despesas com doença na família;

- $\quad$ Plano de saúde;

- $\quad$ Portadores de deficiência física na família;

- $\quad$ Estabilidade no trabalho (pais);

- $\quad$ Ajuda financeira a familiares;

- $\quad$ Pensão alimentícia;

- Dívidas pendentes.
}

Para a concessão das bolsas, o colégio tem a seguinte tabela como parâmetro: 
Tabela 1 - Cota escolar em 2007

\begin{tabular}{|l|c|c|c|}
\hline Valor per capita & Gratuidade na mensalidade & $\begin{array}{l}\text { Bolsa na } \\
\text { Educação Infantil } \\
\text { e } 1^{\mathrm{a}} \text { a } 4^{\mathrm{a}} \text { séries do } \\
\text { Ensino Fundamental }\end{array}$ & $\begin{array}{l}\text { Bolsa de } \\
5^{\mathrm{a}} \text { a } 8^{\mathrm{a}} \text { séries do } \\
\text { Ensino Fundamental }\end{array}$ \\
\hline $\begin{array}{l}\text { 1/4 salário mínimo: } \\
\mathrm{R} \$ 103,75\end{array}$ & $90 \%$ & $\mathrm{R} \$ 37,40$ & $\mathrm{R} \$ 59,90$ \\
\hline $\begin{array}{l}\text { 1/2 salário mínimo: } \\
\mathrm{R} \$ 207,50\end{array}$ & $82 \%$ & $\mathrm{R} \$ 67,32$ & $\mathrm{R} \$ 107,82$ \\
\hline $\begin{array}{l}\text { 1 salário mínimo: } \\
\mathrm{R} \$ 415,00\end{array}$ & $73 \%$ & $\mathrm{R} \$ 100,98$ & $\mathrm{R} \$ 161,73$ \\
\hline
\end{tabular}

No entanto, conforme nos informa a responsável administrativa, essa tabela não pode ser aplicada na maioria dos casos, principalmente nos casos dos alunos de $5^{\mathrm{a}}$ a $8^{\mathrm{a}}$ séries do Ensino Fundamental pelo fato de o valor da mensalidade integral ser muito alto quando acrescido às despesas familiares.

No entendimento da representante legal da Congregação religiosa, o pagamento da mensalidade, mesmo reduzido, é importante e válido, "porque dar tudo de graça não é bom, não valoriza o esforço de ambos os lados", responde a Direção dentro da lógica ditada pelo mundo do consumo.

\subsection{4 - Organização escolar}

A escola funciona em dois turnos, manhã (das $7 \mathrm{~h}$ às $12 \mathrm{~h}$ ) e tarde (das $13 \mathrm{~h}$ às $17 \mathrm{~h}$ ) com turmas mistas de Educação Infantil e Ensino Fundamental. As aulas de Educação Física são dadas com as turmas divididas por sexo. O calendário escolar é semestral, e bimestralmente há a realização do Conselho de Classe de cada turma para a avaliação dos alunos.

A escola tem cerca de 1000 alunos/as matriculados, com 25 alunos por turma em média. Há duas diretoras: uma leiga e uma religiosa, representante legal da congregação e no cargo desde 2005. Contam também com seis coordenadoras: duas da Educação Infantil e primeira série (uma leiga e uma da congregação); uma de segunda a quarta série (leiga); uma da pastoral (leiga); e uma coordenadora pedagógica do Ensino Fundamental (leiga).

Quando chegam, alunos e professores encontram a escola com as salas, mesas, corredores, banheiros, pátio limpíssimos. No portão de entrada são recebidos por um 
funcionário da escola e por outro no corredor do $1^{\circ}$ andar $^{35}$. Notamos que nem alunos e nem professores se atrasavam. As aulas começavam no horário com todos em sala de aula. A maioria dos alunos tinha seu livro por onde acompanhavam a aula. Todos os alunos estavam uniformizados $^{36}$, a maioria de bermuda ou calça jeans azul, tênis nos pés com meia e camiseta brancas, com ou sem manga, com o símbolo do colégio. As mochilas eram as mais diversas e não era permitido mascar chiclete.

Na distribuição das turmas da Educação Infantil e do Ensino Fundamental por idade, a escola prioriza a matrícula, conforme as tabelas abaixo.

Tabela 2 - Turmas e idades da Educação Infantil em 2008

\begin{tabular}{|l|c|c|}
\hline \multicolumn{1}{|c|}{ classe } & $\mathrm{n}^{\mathrm{o}}$ de turmas & Idade \\
\hline Maternal & 1 & 3 \\
\hline $1^{\circ}$ período & 3 & 4 \\
\hline $2^{\circ}$ período & 4 & 5 \\
\hline $3^{\circ}$ período & 5 & 6 \\
\hline $1^{\circ}$ série & 5 & 7 \\
\hline Total & 18 & \\
\hline
\end{tabular}

Por turma, em média 25 alunos $=450$ alunos

Tabela 3 - Turmas e idades do Ensino Fundamental em 2008

\begin{tabular}{|c|c|c|}
\hline classe & $\mathrm{n}^{\mathrm{O}}$ de turmas & Idade \\
\hline 1 a 4 séries & 10 & $8-11$ \\
\hline 5 a 8 séries & 9 & $12-17$ \\
\hline \multicolumn{2}{|c|}{ Por turma, em média 30 alunos $=570$ alunos }
\end{tabular}

A realidade da distribuição dos alunos nas turmas do $2^{\circ}$ segmento do Ensino Fundamental por idade, pode-se conferir nas tabelas abaixo.

Tabela 4 - Turmas e idades de $5^{\mathrm{a}}$ a $8^{\mathrm{a}}$ séries do Ensino Fundamental em 2008

\begin{tabular}{|l|c|c|}
\hline \multicolumn{1}{|c|}{ classe } & $\mathrm{n}^{\mathrm{o}}$ de turmas & Idade \\
\hline $5^{\mathrm{as}}$ séries & 4 & 11 a 15 \\
\hline $6^{\text {as }}$ séries & 2 & 12 a 15 \\
\hline $7^{\text {as }}$ séries & 2 & 13 a 17 \\
\hline $8^{\text {as }}$ séries & 1 & 14 a 18 \\
\hline
\end{tabular}

35 Na parte dos fundos do colégio tem outra entrada para a comunidade do Vidigal onde havia um porteiro encarregado da abertura do portão nos horários de entrada e saída

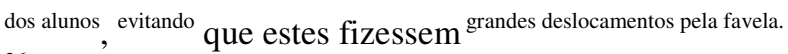

${ }^{36}$ Os uniformes são adquiridos pelas famílias por um valor reduzido. 
Tabela 5 - Número de alunos por idade, de $5^{\mathrm{a}}$ a $8^{\mathrm{a}}$ série do Ensino Fundamental em 2008

\begin{tabular}{|l|c|c|c|c|}
\hline $\begin{array}{c}\text { Alunos por } \\
\text { idade }\end{array}$ & $5^{\text {as }}$ & $6^{\text {as }}$ & $7^{\text {as }}$ & $8^{\text {as }}$ \\
\hline 11 anos & 31 & - & - & - \\
\hline 12 anos & 56 & 11 & - & - \\
\hline 13 anos & 13 & 36 & 27 & - \\
\hline 14 anos & 09 & 12 & 21 & 18 \\
\hline 15 anos & 01 & 07 & 09 & 16 \\
\hline 16 anos & - & - & 03 & 06 \\
\hline 17 anos & - & - & 02 & - \\
\hline 18 anos & - & - & - & 01 \\
\hline TOTAL & 110 & 66 & 62 & 41 \\
\hline
\end{tabular}

\section{2 - A pesquisa: método}

Com o intuito de compreender a dinâmica da instituição escolar optamos por fazer inicialmente um estudo exploratório buscando estudar o impacto da mudança de clientela e as aproximações e distâncias, familiaridades e tensões, entre a cultura escolar e as culturas populares. Todo esse cenário certamente se constitui como elemento fundamental para a construção desse novo projeto educacional. A observação, a análise documental e as entrevistas tiveram um papel importante nesse processo por serem os instrumentos por excelência de uma pesquisa qualitativa sobre as condições de efetivação do conhecimento escolar em uma dada instituição escolar e religiosa que estivera voltada até recentemente para a formação de jovens e crianças pertencentes às classes cultural e economicamente privilegiadas. Pretendemos averiguar, no cotidiano institucional, como esse projeto da escola se materializa nas situações cotidianas. O que propomos aqui, sobretudo, é a elucidação de um saber envolvido na ação pedagógica, assumido por esta instituição escolar nas $5^{\text {as }}$ e $6^{\text {as }}$ séries do Ensino Fundamental.

O levantamento da pesquisa foi feito em dois períodos. A fase inicial (anos de 2004 e 2006) na qual nos dedicamos a acompanhar o cotidiano escolar, período em que optamos pela observação em sala de aula e a realização de algumas entrevistas com o intuito de obter uma primeira aproximação dos diversos setores da escola. Nessa fase, estivemos praticamente em todos os lugares desta escola, conversando, observando, entrevistando as pessoas que estudavam e trabalhavam lá - Direção, professores, alunos, funcionários - e também pais da comunidade atendida pelo colégio. Realizamos, ainda, observação em sala de aula de uma 
turma das $5^{\mathrm{a}}$ séries e de uma das turmas das $6^{\mathrm{a}}$ séries do Ensino Fundamental e participamos de reuniões com professores e Conselho de Classe.

A primeira etapa teve como objetivo perscrutar esse universo cultural específico da escola, procurando aferir o que se passava no dia-a-dia da escola. Quisemos testemunhar o que pensavam da escola seus atores: professores - alunos - funcionários e a comunidade atendida. A idéia era ouvi-los, e buscar uma visão mais detalhada e ampla que uns têm dos outros para fazer um levantamento inicial dos dados que serviriam como base para a elaboração de um roteiro das entrevistas a serem realizadas posteriormente. E quais seriam esses dados? Gatti (2002) esclarece que

[...] na pesquisa, muito importante são os dados com que trabalhamos. E dado pode ser desde um conjunto de medidas bem precisas que tomem até depoimentos, entrevistas, diálogos, discussões, observações, etc. de que nos servimos para a geração de algum conhecimento que acrescente alguma coisa à compreensão do problema que nos interessa. (Gatti, 2002:11)

O problema que nos propusemos a investigar foi verificar como os professores, direção e funcionários viam, ouviam e avaliavam seu novo aluno, se constatariam alguma diferença em relação à clientela anterior, e, em caso positivo, como tal constatação participaria do processo de construção do conhecimento e/ou em suas formas de apreensão dos hábitos e atitudes da nova clientela.

Para o levantamento dos dados e melhor compreensão dessa investigação acrescentamos, ainda, outra definição de dados apoiada no estudo de Moreno et alii (1999) que sustentam, a esse respeito, o seguinte:

[...] estamos usando o termo dados com o sentido de "um produto de interpretação que o sujeito faz dos objetos e fatos perceptíveis". Em nenhum momento se deve entender que consideramos os dados abstraíveis - isto é, interpretáveis - da realidade como elementos objetivos e unívocos. Os dados aos quais nos referimos são dados do sujeito e denotam sua maneira de interpretar as impressões que nele causam os objetos e os fenômenos do mundo exterior, inevitavelmente interpretados por meio dos limitados instrumentos que a natureza pôs à disposição e que estão inscritos em sua bagagem genética, comum à espécie humana e a partir da qual cada sujeito realiza suas construções individuais. (Moreno et alii, 1999:77).

Nesse mesmo sentido, tínhamos consciência de que: 
[...] diante de uma determinada situação ou fenômeno, um observador não retém todos e cada um dos elementos que é possível considerar para representar essa situação ou fenômeno, mas somente alguns, aqueles aos quais, por diferentes razões, atribui significado. Estes passam a fazer parte do que denominamos 'dados' no conseqüente modelo que o sujeito constrói sobre tais situações. Disso deriva que nem todos os dados que é possível abstrair de um fato estão presentes no modelo organizador do sujeito, mas somente alguns, aqueles que para ele resultam mais significativos. Todos os demais, que o sujeito não considera significativos, não são levados em conta e, portanto, não fazem parte de seu modelo organizador. (Moreno et alii, 1999:78-79).

A segunda fase ocorreu em 2008. Significou uma forma de inserção no ambiente da escola para conhecer seu dia-a-dia e a forma como se estava construindo uma outra metodologia de ensino que atendesse a nova população. A partir dessa observação mais geral feita anteriormente, selecionamos quatro casos de alunos para aprofundarmos nosso conhecimento sobre a formação desse aluno por meio das observações já realizadas em sala de aula. Entrevistamos os próprios alunos, seus pais e professores.

\subsection{1 - Anos 2005 - 2006 - $1^{\text {a }}$ etapa}

\subsubsection{1 - ano 2005 - Observação e questionários aplicados aos diferentes atores da escola: alunos, professores, pais e funcionários}

Realizamos, no $1^{\circ}$ semestre de 2005, uma primeira aproximação dos diversos componentes do universo escolar para investigar o que os diferentes atores pensavam sobre a escola.

O estudo tinha como objetivo refletir sobre o que pensavam os atores da escola, de que maneira concebiam a escola presente ou passada, quais imagens tinham dela, quais marcas permaneceram. Isto, que pode ser banal, na verdade, assume relevância se considerarmos a importância da escola na vida de cada um.

Era nosso interesse explorar diferentes atores do universo escolar que compõem o quadro desta instituição de ensino - alunos, professores, funcionários e comunidade atendida, e selecionamos intencionalmente uma sub-amostra de:

- 24 alunos de um total de 1.048 alunos $(2,29 \%)$

- 10 professores de um total de 62 professores $(16,12 \%)$

- 10 funcionários de um total de 54 funcionários $(18,51 \%)$

- 09 integrantes da comunidade de um total de 350 responsáveis $(2,57 \%)$

perfazendo um total de 53 pessoas. Essa seleção foi feita com a coordenadora pedagógica da Educação Infantil da Instituição. A escolha do quadro dos funcionários e dos 
integrantes da comunidade bem como do quadro de professores foi aleatória, tendo como único critério a escolha daqueles que se mostraram disponíveis para participar da pesquisa.

Como era nossa primeira observação na escola, optamos por definir a única $8^{\mathrm{a}}$ série de 2005 para responder ao questionário, por ser o último ano desses alunos na escola.

Os questionários respondidos revelaram a importância da escola para os quatro subgrupos, embora tivéssemos a consciência de que o teor das respostas mostrava sentidos variados do significado de escola, pois no interior da avaliação procurou-se depreender: a importância atribuída por estudantes - o que significava a escola para eles; por professores, no que significou a escola para eles quando criança e/ou ele como professor hoje; para pais, o que significava a escola quando criança, e o que pensam hoje do papel da escola para seus filhos; enfim, sujeitos de categorias sociais diferentes: uns estudantes, outros professores, outros funcionários, outros pais. Entretanto a pesquisa apontou a importância da escola para todos, mesmo que, com sentidos diferentes. Não houve sequer um "caso que criticasse a escola como um todo". Esse dado ratifica a pesquisa de Amaral (2007b), segundo a qual os alunos (para nós não só os alunos, mas todos os objetos de nossa pesquisa) consideram a escola como um lugar essencial em suas vidas e ressaltam ainda ser o melhor caminho para melhorar suas vidas.

No entanto, perguntamo-nos por que ninguém criticava a escola? Todos pareciam ter presente a consciência da importância da educação como escolarização. Mesmo que pudesse haver alguma insatisfação com o que a escola faz, em termos de escolarização, todos os participantes da pesquisa não ousavam questionar o seu sentido, sobretudo se considerarmos que o fato de a escola confessional passar a atender crianças de baixa renda fora considerado uma espécie de "dádiva". As críticas eram sempre a respeito da eficiência da escola, mas não do modelo de escola. E mesmo assim, as preocupações das pessoas se voltavam mais sobre os motivos do filho de tal idade ou o aluno tal não estarem aprendendo aquilo que se ensina do que a preocupação se a criança deveria ser submetida, naquela idade, a esse tipo de processo.

Enfim, a escola tal qual concluem Ribeiro e Valença (1999)

[...] não deixa de ocupar um espaço bastante poderoso no imaginário das pessoas e ainda constitui o meio pelo qual circulam os sonhos de ascensão social, de aquisição de um saber que promova o acesso a melhores condições de vida que o processo educacional não pôde proporcionar aos pais da maioria dos alunos (1999, In: Freller, 2001:77) 


\subsubsection{2 - ano 2006 - Observações das $5^{\mathrm{a}}$ e $6^{\mathrm{a}}$ séries}

Decidimos realizar a observação nas turmas de $5^{\mathrm{a}}$ e $6^{\mathrm{a}}$ séries, uma vez que a diretora mencionou sua preocupação com as turmas, com os adolescentes, e as dificuldades que encontrou para a implantação do projeto nesse segmento. Para ela havia duas explicações: os alunos virem de outras experiências escolares da escola pública, ou seja, não terem feito a Educação Infantil e as séries iniciais no colégio onde estariam podendo acompanhar o mesmo ritmo dos demais alunos; e os professores, por serem os mais antigos e terem tido experiência com outra camada social - classe média e média alta - e que tais experiências de um ou outro grupo pôde contribuir ou dificultar a implementação de uma nova proposta pedagógica que se adequasse às necessidades da clientela atual.

O consentimento para a realização desta pesquisa foi obtido e ficou acordada a possibilidade de um intercâmbio de experiências que viesse a fornecer um embasamento teórico que alimentasse a prática desenvolvida no trabalho institucional.

A $5^{\mathrm{a}}$ série observada era composta de 29 alunos, 17 meninas e 12 meninos, e a $6^{\mathrm{a}}$ série, 26 alunos, 16 meninas e 10 meninos.

A maioria dos alunos entrou à época da implantação do projeto Centro Popular Stela Maris, ou seja, em 2000, conforme registramos nas tabelas abaixo:

Tabela 6 - Alunos e Data da Admissão - $5^{\mathrm{a}}$ série do Ensino Fundamental

\begin{tabular}{|c|c|c|c|c|c|c|c|}
\hline & 1997 & 1999 & 2000 & 2002 & 2004 & 2006 & Total \\
\hline Mulheres & - & 1 & 14 & 2 & - & - & 17 \\
\hline Homens & 1 & 2 & 7 & - & 1 & 1 & 12 \\
\hline
\end{tabular}

Tabela 7 - Alunos e data da admissão- $6^{\text {a }}$ série do Ensino Fundamental

\begin{tabular}{|c|c|c|c|c|c|c|c|}
\hline & 1997 & 1998 & 1999 & 2000 & 2002 & 2005 & Total \\
\hline Mulheres & 1 & - & 1 & 8 & 5 & 1 & 16 \\
\hline Homens & 2 & 1 & 1 & 5 & 1 & - & 10 \\
\hline
\end{tabular}


A observação foi feita durante 18 horas (quatro manhãs) na $5^{\mathrm{a}}$ série, com registro das aulas consentido pelas professoras. $\mathrm{O}$ acompanhamento das aulas na sala da $6^{\text {a }}$ série foi realizado com a mesma duração (outras 18 horas).

Fomos a campo com o intuito de observar a sala de aula, lugar privilegiado no qual professores e alunos contribuem ativamente para a constituição da escola. Como pesquisadora, candidata a doutorado, tínhamos o sentimento de estar construindo a pesquisa à custa dos informantes. Esse sentimento perpassou várias vezes a investigação, principalmente a coleta de dados na sala de aula. Os professores "concordaram" em ser observados e nós tínhamos receio de que a observação fosse intimidá-los no transcurso das suas aulas, sabedores de que estavam expostos ao crivo da crítica. Porém, pensávamos que caso houvesse sua recusa, 'corriam o risco' de atrair a atenção da Direção e poderiam incorrer em suspeita de tentar esconder sua "incompetência”.

Em geral, conforme sugere o pesquisador canadense Peter McLaren (1991), esforçávamo-nos para que o trabalho de campo pudesse ser mais do que uma presença curiosa e incômoda, e, por isso, sentávamo-nos no fundo da sala e, assim, mantínhamo-nos da maneira a mais discreta possível em sala de aula.

O quadro de educadores, incluindo coordenação e professores, contava com oito professoras antigas ${ }^{37}$ e quatro professoras novas. A análise da observação está bem detalhada no decorrer deste capítulo, principalmente no item - Práticas e processos em ação no cotidiano escolar.

\subsection{2 - Ano 2008 - $2^{\mathrm{a}}$ fase: entrevistas}

\subsubsection{1 - Entrevistas com os professores:}

O foco das entrevistas consistiu em depreender como os professores viam seus alunos do ponto de vista de ensino e em termos de seus usos e costumes.

Os professores foram selecionados para serem entrevistados com base nos seguintes critérios:

1. Estavam nas salas das $5^{\text {as }}$ e $6^{\text {as }}$ séries no ano em que a observação foi feita;

\footnotetext{
${ }^{37}$ Chamamos de 'antigas' as professoras que trabalhavam no colégio antes da mudança de clientela
} 
2. Foram professores das turmas em que selecionamos os estudantes para os estudos de caso;

3. Tinham participado do processo anterior, ou seja, trabalhavam antes da implantação do projeto e permaneceram no quadro docente após o ano 2000.

As entrevistas com os professores do colégio foram feitas em dias diferentes e

norteadas pelas seguintes perguntas:

1. Quais são as suas expectativas em relação ao aprendizado dessas crianças: "alunos bem-sucedidos" - "alunos com sucessos inconstantes" - "alunos com fraco desempenho e sem sucesso acadêmico" - "alunos com fraco rendimento escolar"; o que você entende por esses quatro critérios de avaliação?

2. Em relação às suas expectativas quanto ao aprendizado dessas crianças, qual a diferença que você vê entre a expectativa da classe média e da camada popular em relação ao aprendizado?

3. Você acha que tais expectativas tiveram alguma diferença na adoção dos métodos de ensino ou mesmo no modo de organizar a classe e programar as aulas em função desse novo público?

4. Você tem alguma concepção sobre a cultura que a escola deva transmitir às crianças, considera que existe alguma diferença na transmissão da cultura da classe média e das classes populares. Nesse sentido como definiria cultura?

As entrevistas foram analisadas ao longo do trabalho.

\subsubsection{2 - Quatro estudos de casos - 2008}

\section{Estudos de caso: Diva - Homero - Miriam - Nara ${ }^{39}$}

Selecionamos quatro alunos, hoje todos estudantes da $7^{\mathrm{a}}$ série (alunos que estavam na $5^{a}$ série onde fizemos a observação em 2006). Tivemos como critério o desempenho acadêmico e chegamos a esses quatro alunos para serem entrevistados com o perfil de alunos rotulados pelos professores em Conselho de Classe como: "alunos bem-sucedidos" - "alunos com sucessos inconstantes" - "alunos com fraco desempenho e sem sucesso acadêmico" "alunos com fraco rendimento escolar":

- Diva - aluna bem-sucedida, com elementos constitutivos para seu projeto de vida que indicam a figura de pais cuja esperança de um futuro melhor é depositado na formação educacional da filha.

\footnotetext{
${ }^{38}$ Escolhemos esses critérios a partir da observação das aulas nas turmas de $5^{\mathrm{a}}$ e $6^{\mathrm{a}}$ séries.

${ }^{39}$ Os estudantes serão designados por nomes fictícios e seus pais autorizaram sua participação na pesquisa.
} 
- Homero - aluno com sucessos inconstantes e provisórios devido a problemas de comportamento. Não se submete docilmente à autoridade do professor, apesar de contar com figuras parentais que valorizam a escola e acreditam que esta possa preparar o filho para alcançar um lugar mais valorizado na sociedade.

- Miriam - representante da aluna sem sucesso acadêmico, com muita dificuldade de compreensão, apesar dos esforços que faz para ter êxito escolar. Os pais são quase analfabetos e têm a filha em alta conta por já estar alfabetizada.

- Nara - aluna com fraco sucesso acadêmico e pouco investimento nos estudos e demais tarefas.

Tabela 8- Caracterização dos estudantes dos estudos de caso

\begin{tabular}{|c|c|c|c|c|c|}
\hline Nome & Idade & Nascimento & $\begin{array}{l}\text { Período de } \\
\text { entrada }\end{array}$ & Teve outra escola & $\begin{array}{c}\text { Bairro que } \\
\text { mora }\end{array}$ \\
\hline Diva & 14 & $1^{\circ}$ agosto 1993 & $\begin{array}{l}\text { Classe de } \\
\text { Alfabetização }\end{array}$ & $\begin{array}{l}\text { Sim }-S^{\text {tos }} \text { Anjos - } \\
\text { Leblon }\end{array}$ & Vidigal \\
\hline Homero & 13 & $\begin{array}{l}19 \text { dezembro } \\
1994\end{array}$ & $3^{a}$ série & $\begin{array}{l}\text { Sim - Metodista - na } \\
\text { Rocinha }\end{array}$ & Vidigal \\
\hline Miriam & 12 & 15 março 1995 & $\begin{array}{l}\text { Classe de } \\
\text { Alfabetização }\end{array}$ & Sim - não lembra & Vidigal \\
\hline Nara & 12 & $\begin{array}{l}28 \text { novembro } \\
1995\end{array}$ & $\begin{array}{l}\text { Classe de } \\
\text { Alfabetização }\end{array}$ & $\begin{array}{l}\text { Sim - Sta. Rita - no } \\
\text { Vidigal }\end{array}$ & Vidigal \\
\hline
\end{tabular}

Tivemos como objetivo indagar como as crianças se viam e como eram vistas pelos professores do ponto de vista do método de ensino e sobre suas concepções de cultura.

Utilizamos os seguintes instrumentos como parte da pesquisa: entrevista em grupo, entrevistas individuais, escrita e desenho. No entanto, vale ressaltar que não era nosso intuito fazer um diagnóstico e, sim, investigar a relação dos alunos com a escola e, para isso, analisar alguns traços do desenho no sentido de obter uma ilustração da sala de aula, de fora da sala de aula, do espaço educativo, do espaço externo à escola e da relação mais ou menos próxima entre professor e aluno.

Tivemos um encontro com o grupo de alunos selecionados para o estudo de caso, no intuito de se apresentar a proposta do trabalho e solicitar sua participação nas entrevistas. Três deles se lembraram do período em que a observação foi feita em sua sala de aula, e coincidentemente a estudante 'rotulada' como desinteressada disse não se lembrar. Indagaram 
por que precisávamos deles, então o trabalho foi explicado, bem como a intenção de se fazer as entrevistas individualmente, assegurando que seus nomes não seriam mencionados nas respostas. Com tudo bem esclarecido, todos concordaram em fazer parte da pesquisa, que passamos a relatar. 


\section{3 - O trabalho com os alunos}

\subsection{1 - A história da estudante: Diva}

Diva é de constituição forte e estatura alta. Tem cabelos pretos, ondulados e longos, que contrastam com sua pele clara. É filha e neta de paraibanos e cearenses que migraram para o sudeste em busca de melhores condições de vida.

Mora com seus pais e uma irmã na favela do Vidigal em casa própria (dois quartos, sala, banheiro e cozinha): "morar em favela e ainda em casa alugada! Ninguém merece!" disse a mãe e contou que, quando ela (mãe de Diva) era pequena, sua mãe deixou os filhos no norte e veio tentar a vida na cidade grande. Eles ficaram com o avô, que não deixava os netos irem à escola, alegando que nem ele nem os filhos tinham estudado e, por isso, os netos também não iriam estudar: "foi um custo ele permitir que os netos fossem para a escola, precisou minha mãe brigar muito, mas era a mentalidade da época", justifica.

Ela frequentou a escola até o $4^{\circ}$ ano e depois parou, segundo ela, porque era muito levada! Já seu marido estudou até o $2^{\circ}$ ano primário.

Diva é a primeira filha do casal, hoje está com 14 anos de idade e estudando na $7^{\text {a }}$ série. Ela entrou nessa escola vinda de outra no Leblon, pois, apesar de ter passado para o $1^{\circ}$ ano, seus pais notaram que ela não sabia ler e só fazia cópia. Nessa ocasião, a escola Stella Maris havia criado uma classe para atender esses casos: Alfa 1. Depois, durante o ano, os alunos eram promovidos para a $1^{\mathrm{a}}$ série. A mãe se interessou por essa proposta e colocou a filha na escola, frequentando essa turma "em meio ano já estava alfabetizada".

Diva já viajou para o Ceará para visitar suas tias, da família de sua mãe. Em casa gosta muito de usar o computador, a Internet e ouvir música. Dorme com sua irmã e sempre morou na mesma casa. Da janela vê outras casas. Acorda diariamente com o despertador do celular da mãe, mas ela mesma não tem um.

Diva quer ser médica pediatra quando crescer, porque ouve em casa que médico salva vidas. Diz que, antes, sempre gostou de brincar de muitas coisas, mas que agora se diverte mais com o videogame. Para ela, até hoje, a maior mudança foi crescer e parar de brincar de boneca, e as coisas mais importantes na vida são: a família, os amigos, os princípios morais, como por exemplo, sempre ser honesto e não pegar as coisas dos outros. Acha sua família muito especial. Gostaria de esquecer as coisas que aconteceram de ruim e lembrar as coisas 
boas que viveu. Acha que quando for adulta vai poder ser independente. O fato de Diva ter conseguido ser alfabetizada e depois ter acompanhado normalmente as séries seguintes deve ter contribuído para que ela adquirisse a confiança que ela demonstra ter em seus próprios recursos. Diva parece reconhecer o esforço feito pela família para que lograsse tal êxito, acrescido dos seus bons resultados escolares, que deram à ela força e auto-estima.

O pai de Diva trabalha durante o dia como porteiro, e sua mãe não trabalha. Diva não conheceu seu avô, pai de sua mãe. Já seus avós paternos moram no Vidigal e ela vai muito lá porque é mais perto. Eles vieram da Paraíba para o Rio em 1993, "porque aqui tem mais condições de trabalho", conforme relata a garota.

Diva, nos dias de folga, ou fica em casa no computador ou vai à casa da avó materna em Botafogo, que mora com o segundo marido. Em casa, vê TV com a irmã, principalmente a novela Malhação, e assiste ao Big Brother. No computador usa a Internet ou joga cartas. Diva diz gostar de ler os livros que ganha, e o que mais gostou foi o Diário de Anne Frank (FRANK, Anne e FRANK, Otto, 1947).

Diva nunca trabalhou, mas em casa ajuda nos afazeres domésticos, como: arrumar a casa, lavar a louça, varrer a casa, "esse tipo de coisa", como diz ela. Conta que, às vezes, faz sem que a mãe peça e, outras vezes, a mãe precisa pedir.

Ela só vê o pai no fim do dia porque ele sai cedinho, mas que seu dia começa com um pãozinho que ele compra do padeiro que passa por sua casa todo dia pela manhã, o que demonstra o cuidado paterno com a família.

Quando chega a casa, o almoço já está pronto: "é só esquentar". Daí dorme até umas 5 horas da tarde e acorda "quando acaba o sono". Faz dever de casa na mesa da sala e vê TV.

Não falta à escola, por dois motivos: "Porque gosto de vir e meus pais não deixam faltar", salienta. Ela considera o ensino como a coisa mais importante em uma escola. Tem medo de repetir o ano e de suspensão. Conta que se lembra que na $4^{\mathrm{a}}$ série os alunos escolhem se vão escrever a lápis ou a caneta e também podem escolher seus lugares na sala, mas que os alunos vão fazendo seus grupos e acabam sentando mais ou menos no mesmo lugar. Acha que o melhor na escola são os amigos e suas melhores amizades são as da escola.

Seus pais gostam que ela estude e ela acha que se estudasse "seria esperta". Acredita que seus colegas acham que ela é uma pessoa legal e ela concorda com isso, demonstrando 
sua auto-confiança. Seus professores devem achá-la uma boa aluna, segundo ela. Achou a $1^{\text {a }}$ série, a série mais fácil, e a mais difícil está sendo a atual - $7^{a}$ série. Escola, segundo ela, lembra educação, respeito, aprendizado, amizade e carinho. Esclarece, desse modo, os valores que lhe foram transmitidos pelos pais e, pelo jeito, pela escola também.

Para ela os meninos da sua idade preferem jogar bola, mas as garotas pensam em coisas mais sérias como planejar um futuro. Quanto à escola, acha que o melhor professor é aquele que brinca com os alunos, que ouve o que os alunos falam, que "seja quase da família". Gostaria que a professora desse bom-dia quando ela chegasse à escola, e se fosse tirar dois retratos da escola escolheria o pátio e o ginásio de esportes "lá embaixo".

Diva vai todo dia a pé para a escola, e na $4^{\mathrm{a}}$ série passou a ir sozinha levando sua irmã. Na saída, voltam juntas de Kombi por causa da subida. No dever, quando Diva tem dúvidas, espera até o dia seguinte para perguntar aos professores, porque os pais não estudaram até a $7^{\text {a }}$ série: "Não tiveram oportunidade", comparando com sua própria situação e demonstrando, de algum modo, compreender a diferença de oportunidades entre os pais e ela mesma. Diz que é boa aluna, com média entre 7 e 9, que respeita os professores e esses não reclamam dela. Seus pais acompanham seus estudos, os dois vão às festas e reuniões de pais (mais a mãe que o pai "porque ele trabalha muito"). Um depoimento que demonstra quão fundamental parece ser para o bom desempenho da criança a confiança em sua capacidade de aprender, assim como o apoio e o interesse dos pais e, claro, da escola, ou mais especificamente dos professores.

Se acontecesse um caso de um aluno fazer algo errado e a turma fosse punida por isso, Diva diz que não deduraria o colega, porque é seu amigo e "fica ruim depois", mas falaria para ele assumir por estar errado, o que demonstra ter um juízo moral desenvolvido, assim como critérios de justiça e sentimentos de equidade; tem como princípio considerar as circunstâncias atenuantes como ser um amigo, sem no entanto apoiá-lo (e ser injusta com a turma), mas, sim, incentivá-lo a assumir a responsabilidade dos seus atos, como apontam as pesquisas de Piaget $(1932 ; 1994)$. Em qualquer problema na escola falaria com a diretora. A disciplina que ela gostaria de ter, caso pudesse escolher, seria História, e tiraria Português, porque não gosta e acha uma matéria chata.

Achou interessante pensar em tirar alguma disciplina da grade curricular e escolheu Português. Para ela, a escola presta porque é o lugar onde se aprende muita coisa e "sem estudo não se consegue nada na vida". Acha que o mundo sempre foi assim, mas antes era 
mais fácil conseguir alguma coisa sem estudo, "porque podia estudar menos e mesmo assim conseguia as coisas melhores". No caso, parece pensar na geração de seus pais e avós.

\section{Desenhos:}

A representação da sala de aula de Diva parece informar um espaço abstrato sem presença humana, uma vez que não há nem

(1)

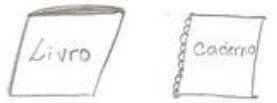

professor nem aluno, só conteúdo.

Seu desenho da vida fora da sala de aula parece expressar que se sente valorizada através do esporte, e, desse modo, faz parte de seu grupo, que tem a auto-estima aumentada via esporte, ao mesmo tempo que é um lugar de amizade e diversão.

A vida na escola parece demonstrar que alimenta a expectativa de que possa lhe trazer felicidade.

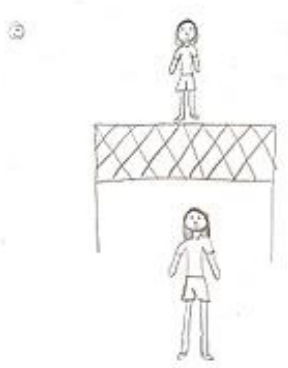
gas pósio omigst 
Já a vida fora da escola é o lugar onde se pode fazer o que se quer, comunicar-se com os outros, porém, sem ser vista.

O desenho da relação professor-aluno foi representado como uma fotografia, todos olhando para a câmera, como se fosse o cartão-postal da escola, sem demonstrar, por exemplo, por que escolheu a aula de português, justamente com a qual tem problemas devido a dificuldades com a professora e que ela tiraria da grade curricular. Em todo caso, parece não ter sido estabelecido um vínculo positivo com o conhecimento oriundo dessa relação. Provavelmente se não está havendo um

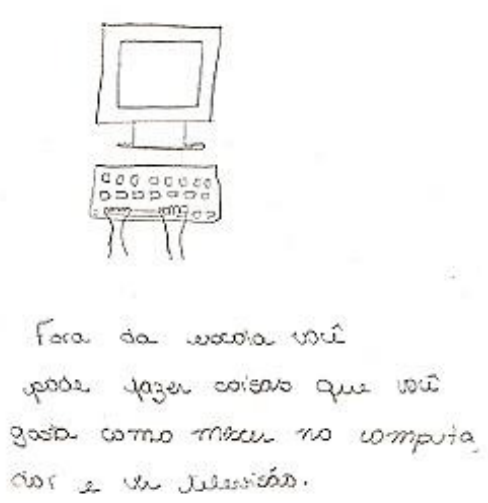

encontro, muita coisa deve estar sendo perdida, pois, para ela, há desinteresse dos alunos pelo que está sendo dado em sala de aula.
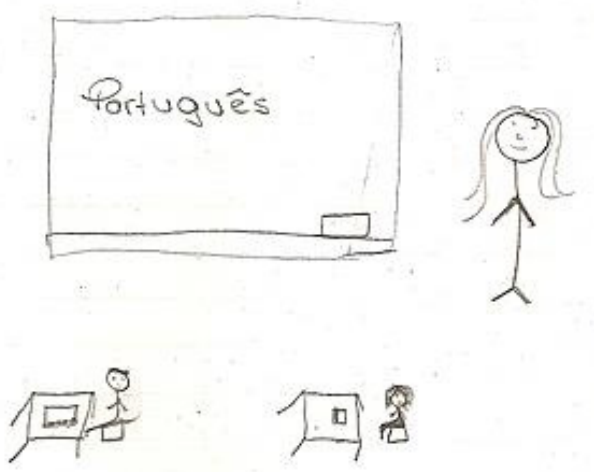

O Subgrupo: para Diva esse subgrupo que respondeu à pesquisa é formado por quatro pessoas, "uma espécie de informantes" para pesquisa, "prá esse trabalho". Acha que eles são bem diferentes porque "pensamos de jeito diferente" e, por isso, acha que a pesquisa "vai ficar legal". "Eu acho que nós pensamos diferente por causa do nosso jeito de agir", embora não conseguisse dizer de que modo se dava essa diferença. 


\section{Coisas que eu sei que aprendi na escola: Diva $^{40}$}

Diva acha que as três coisas que aprendeu na escola foram:

- "a ler e escrever porque quando eu entrei no colégio eu não sabia fazer isso";

- "o interesse pelo esporte. Agora todo jogo de vôlei eu vejo porque aqui eles estimulam você a procurar saber sobre o esporte"

- "a união aqui na escola ficou mais forte, eu acho que agora eu consigo viver melhor em grupo do que antes".

\section{A representação dos professores e da coordenação acerca de Diva}

Para os professores, Diva é extremamente educada, delicada, estudiosa e não é dada a enfrentamentos. Participa da aula e questiona, mas não discute com os professores, "fala $o$ que ela quer, mas dentro do razoável". Já foi monitora (quando um aluno se propõe a dar aula para os colegas) e todos os alunos achavam que ela sabia explicar. Como ela estava na $7^{\text {a }}$ série, dava aula para os alunos das $5^{\mathrm{a}}$ e $6^{\mathrm{a}}$ séries. "É interessante que até fazia fila para ter aula com ela", comentou um dos professores.

São unânimes ao afirmar que é uma boa aluna no sentido de corresponder ao que a escola propõe. É uma menina alegre, risonha e não faz bagunça. É uma menina interessada. É uma aluna maravilhosa, excelente, chegaram a dizer alguns deles. Além de tirar boas notas, tem bom comportamento e participação na escola. Acrescentaram que ela tem facilidade para aprender.

Para eles é a estrutura familiar que dá condições para a criança ser uma boa aluna, é ter uma mãe presente. "Tem uma família mais estruturada, inclusive sua irmã é parecida com ela em atitudes. A mãe é muito delicada no falar, comparece a todas as reuniões, é uma pessoa presente na escola”, relata a coordenadora pedagógica, assinalando a importância da aproximação família e escola nos valores, atitudes, comportamentos, etc.

É uma menina agradável, interessada, e se tiver dificuldades, ela tenta supri-las, perguntando e buscando auxílio. Diva é "uma menina em quem eu tenho muitas esperanças. Desses quatro alunos, eu diria que ela é a menina que eu vejo com mais chances de alcançar um bom resultado, isto quer dizer, quem tem mais chances de um futuro".

\footnotetext{
${ }^{40}$ Textos na íntegra
} 
Conforme o relato dos professores, Diva é uma menina que está sempre participando, embora tenha passado por momentos de maior inibição, como quando vinha de casaco, recusando-se a tirá-lo porque se considerava “mais para gordinha”, mas que agora já está se libertando disso. Ela brinca e, das três meninas, os professores acreditam que ela mantenha o melhor relacionamento na turma, uma vez que se dá bem com todos e participa de todas as atividades.

Os professores pensam que Diva seria uma boa aluna em qualquer escola que ela fosse. O que não é verdade, pois na outra escola ela não conseguia aprender a ler e só deslanchou quando os pais procuraram essa escola, que eles sabiam prezar um ensino de bom nível, que se preocupava em avaliar os resultados obtidos, embora, como se pode depreender do relato da garota, identifique-se, nesta escola, um distanciamento e até mesmo uma oposição entre, de um lado, o universo cultural e o campo de interesses dos alunos e, de outro, os objetivos educacionais e as pretensões de formação cultural dos professores.

\section{Entrevista com L. - mãe de Diva}

A mãe de Diva trabalha duas vezes por semana como manicure e atualmente está fazendo um curso de cabeleireira para se aperfeiçoar. Seu marido trabalha como porteiro e a família vive com cerca de dois salários mínimos.

Para "relaxar", gosta de ver novela quando pode, não costuma ir ao cinema ${ }^{41}$, "gosta mesmo de ficar em casa", segundo ela. Às vezes sai com as filhas para ir "ver o shopping", porque elas adoram.

As meninas vão para a escola e voltam sozinhas, mas quando as filhas eram menores, ela as acompanhava. Contou que quando o Stella Maris abriu suas portas para a comunidade, o esposo não optou por colocar suas filhas no Colégio. A Diva estudava em uma escola da Prefeitura em outro bairro, mas a mãe percebeu que ela já ia para a $1^{\mathrm{a}}$ série, embora não soubesse ler nada. Vejamos como demonstra sua preocupação com a formação de suas filhas desde o início de sua formação: “Como uma criança pode ir para a primeira série sem saber ler? Aí, foi quando eu falei com ele e a gente veio inscrever ela aqui. Na época ela nem podia

\footnotetext{
${ }^{41}$ Consideramos que essa pergunta (sobre ida ao cinema) foi inadequada em razão das condições financeiras das entrevistadas.
} 
ficar aqui, mas a diretora montou uma turminha que não sabia ler. Ela foi alfabetizada ali, porque onde ela estudava, ela não foi" [alfabetizada].

Nesse sentido acrescenta ainda: "O que eu espero de uma escola? Puxa! Eu espero que as minhas filhas aprendam. Venham a aprender, venham a ser alguém na vida. Ter o estudo que eu não tive. E, claro, com a minha ajuda. Não é só a escola. Também tem que ter a minha parte também”, o que demonstra como assume sua parcela de responsabilidade pela formação dos filhos. Depois, esclarece seu modo de pensar a esse respeito: "Porque não adianta eu botar minhas filhas no colégio e não procurar saber o que elas estão estudando. É ela chegar e eu perguntar: como foi a escola? Como foi o seu dia? Fez o dever de casa? Vai fazer. Não é só mandar elas virem para a escola e deixar... Também tem que ter minha parcela. Tenho que acompanhar, tenho que estar sempre presente, o que está acontecendo, o que não está acontecendo".

Relata que a responsabilidade pela formação das filhas é assumida, não apenas por ela, mas pelo casal e que isso contribui para a organização das filhas para a realização das tarefas escolares: "Meu marido todo dia quando chega é a primeira coisa que ele procura saber. Ensina o dever de casa, direitinho. Senta com elas, conversa, explica. Até porque a gente nem precisa cobrar muito. Elas chegam, sentam e vão fazer o dever".

Na época que sua mãe a inscreveu na escola, Diva estava com sete anos, ainda sem o mínimo domínio do processo de alfabetização. L. contou que, depois que Diva entrou nessa escola, em seis meses já estava lendo. "E ficou anos no colégio do Leblon e não leu nada, não sabia nada. Não sabia nem juntar a "família" (das letras). Ela não sabia nada. Quer dizer, ia para a $1^{a}$ série! Isso não existe".

Sobre a importância dos estudos para a vida futura da nova geração, salienta sua preocupação com o avanço tecnológico e o receio de que seus filhos não tenham uma formação capaz de acompanhar as necessidades de um mercado de trabalho mais exigente: "hoje em dia está tudo muito avançado. A tecnologia está muito avançada. Você com estudo já está ruim. Você vê muita gente que tem estudo, mas não tem emprego. Eu mesmo não tenho estudo. Tive que procurar uma profissão para eu fazer. Seja qual for. Se você não tiver um estudo tem que ter uma profissão. Não só ter a profissão. Procurar fazer da sua profissão uma coisa boa". Ao mesmo tempo, sustenta a necessidade do envolvimento com o exercício responsável do trabalho: "Trabalhar com carinho. Você aprendeu você tem que fazer aquilo 
com amor. É você trabalhar direito. Não adianta você fazer uma profissão e chegar lá trabalhar e fazer mal feito. Não vão te querer mais. Quem vai querer um profissional ruim?”

Pensa que os pais também transmitem cultura, incluindo a formação moral da criança, e esclarece de que modo:

\begin{abstract}
"Eu procuro ensinar minhas filhas do jeito que eu fui criada. Procuro ensinar coisas do bem. Não praticar o mal nunca. Não sou de falar palavrões porque eu não gosto. Porque se eu for falar minhas filhas também vão fazer a mesma coisa. Eu lembro que eu aprendi muito do meu avô. Ele sempre falava: minha filha respeite para você poder ser respeitada. Você tem que ter respeito. Porque se você não se impor, não se valorizar, quem é que vai valorizar? Ninguém”.
\end{abstract}

Bourdieu (1979a) assinala que a aquisição de um conjunto de qualificações intelectuais é transmitido pela família, pelo ambiente social e/ou produzidas pelo sistema escolar, mas esta demanda tempo. Ora, para dilatar o empreendimento de aquisição de capital cultural é preciso uma exposição repetida a condições sociais definidas, que possibilite tendências a perceber, sentir, fazer e pensar de certa maneira42.

L. diz não se lembrar muito acerca do que aprendeu na escola porque, conforme seu relato: "tem tantos anos que eu estudei. Já esqueci de muitas coisas. Não tenho muitas lembranças assim de aula. Eu sei ler e escrever. De brigar. De soletrar".

Contou que era muito levada no colégio, mas que ocultou das filhas o seu modo de agir irreverente na escola para lhes dar um bom exemplo, o que demonstra como, a seu modo, procurava incutir nas crianças a noção de responsabilidade, ao mesmo tempo em que diferenciava os momentos do trabalho da educação dos momentos de divertimento.

\begin{abstract}
"Graças a Deus minhas filhas não me puxaram. Lógico que nem falei para elas que eu era tão levada. Eu cobro muito delas. Eu falo para elas o contrário do que eu fui no colégio. Para elas não brigarem e procurar sempre estar com boas amizades no colégio. Eu falo: minha filha, colégio a gente vai para estudar e não para brincar porque para isso tem a hora do recreio".
\end{abstract}

É interessante constatar que a mãe de Diva é a que mais se aproxima da ideia do que seja cultura em Hannah Arendt (1979). Em seu artigo sobre a crise da educação, a autora marca a diferença entre cultura (o tempo de lazer, o tempo de sobra) e entretenimento (o tempo vago que é 'matado'), e explica: "A cultura relaciona-se com objetos e é um fenômeno do mundo; o entretenimento relaciona-se com pessoas e é um fenômeno da vida”. Justamente é no tempo que "estejamos libertos de todos os cuidados e atividades requeridos pelo processo vital e livres portanto para o mundo e sua cultura -, ele é antes um tempo de sobra,

\footnotetext{
${ }^{42}$ Essa busca de capital cultural é bem retratada no filme Les gôuts des autres realizado por Agnès Jaoui.
} 
que sobrou depois que o trabalho e o sono receberam seu quinhão" (ARENDT: 1979:258 grifo da autora).

L. diz que hoje em dia quase não lê nem escreve: "escrever eu escrevo, o pouco que eu lembro eu não escrevo bem". Mas reconhece a importância de escrever bem para o bom exercício da função de consultora, embora admita as deficiências em sua formação. Trabalha como consultora de uma firma de cosméticos e precisa, segundo ela, "anotar os produtos direitinho".

Considera que cultura seria teatro, ir a um cinema, ter uma boa formação dentro de casa, os pais estarem ali sempre acompanhando. Não acha que televisão "passa muita cultura", demonstrando o discernimento que é capaz de ter em relação à qualidade do que é oferecido pela mídia em comparação com o que realmente poderia lhes proporcionar algum capital cultural. Para Arendt (1979), “as mercadorias que a indústria de divertimentos proporciona não são 'coisas', objetos culturais cuja excelência é medida por sua capacidade de suportar o processo vital e de se tornarem pertences permanentes do mundo", mas são destinados a se consumirem no uso, exatamente como quaisquer outros bens de consumo. $\mathrm{E}$ enfatiza: "a verdade é que todos nós precisamos de entretenimento e diversão de alguma forma, visto que somos sujeitos ao grande ciclo vital" (ARENDT, 1979: 258-259).

A mãe de Diva esclarece, nesse sentido, que suas filhas não são incentivadas a ver televisão muito tempo, a não ser um desenho de vez em quando. Mas anuncia um outro elemento da mídia que atrai as filhas: "Elas gostam muito de um computador". Ela mesma ressalta que nem vê TV, porque: "para ver violência basta você sair na rua e você está vendo", denunciando, assim, a tensão cotidiana a que estão submetidos e as dificuldades enfrentadas em seu dia-a-dia na cidade do Rio de Janeiro.

Usa o rádio para ouvir a pregação evangélica porque nela encontra, ao menos, "uma letra saudável, uma música bonita para se escutar".

Acha que na verdade não tem muita cultura, e justifica: "Principalmente onde eu fui criada que é uma cidade pequena. E a capital é mesmo Fortaleza e eu nunca nem fui a Fortaleza", referindo-se ao local onde nasceu, uma pequena cidade do interior do Ceará.

Quando terminamos a entrevista, ela reiterou:

"Essa escola aqui para mim foi uma bênção. Só o fato de eu ter minhas filhas aqui, de estudar perto de casa, de eu não ter o trabalho de levar para a escola. Eu levava a Diva todo dia para 
a outra escola. Primeiro Diva ficou numa creche lá na Cruzada. Na época, tinha que pagar noventa reais. Era dinheiro naquela época. A própria prefeitura colocou ela na escola do Leblon. Um ano ela estudou lá. No outro ano ela chegou: "mamãe eu vou para primeira série”. Eu disse: 'Como, se você não sabe escrever?'Ela já sabia escrever, mas ler para dizer aquilo que ela escreveu ela não sabia. Nada, nada, nada. E por mais que eu falasse: 'oh, você vai estar formada sem ler', e ela dizia, 'mas mamãe, não entra na minha cabeça'. 'Então você vai para a primeira série para aprender a ler, vai para a segunda série sem saber nada e vai passando por passar. É isso que vai acontecer'. Isso quando tinha aula. Porque nem todo dia tinha. Aí você ia, dava viagem perdida e você voltava. Fazer o que? Eu falo para minhas filhas, 'claro que você vai me obedecer, você é pequena e vai me obedecer, mas você tem que estudar focando em você. Naquilo que você quer ser. Você não vai querer ser que nem eu. Você vai querer ser manicure? Cabeleireira?' Não quero isso para elas. Quero que elas tenham o que eu não tive. Em casa e no colégio ensinam coisas boas, mas e fora? Eu sempre falo para elas: 'minha filha no dia que você tiver um amigo que lhe chame para fazer coisa errada fuja dessa pessoa porque amigo é aquele que tira o amigo do buraco".

L. reafirma claramente sua preocupação com uma formação de qualidade para suas filhas e quão decepcionada se encontrava com a escola pública frequentada por Diva, antes de ir para o Colégio Stella Maris. A proximidade dos sistemas de valores entre família e escola aumenta as possibilidades de sucesso e adaptação da criança, constata Nicolaci-da-Costa (1987). Dois são os motivos da preocupação materna: um diz respeito ao desejo de que tenham melhores oportunidades de trabalho do que os pais, demonstrando o desejo de ascensão; o outro refere-se à sua preocupação em afastá-las do fantasma que ronda a comunidade: o tráfico e o crime que aliciam as crianças para atividades ilegais. A mãe de Diva atesta sua preocupação que caminha em um sentido parecido com o do movimento do hip-hop, que denuncia como são as condições de vida dos moradores da favela e luta contra o aliciamento das crianças pelo tráfico, valorizando em contrapartida, o empenho nos estudos. Caminho que exige maior esforço, mas também mais seguro do que os que fizeram de sua vida precária a condição para uma ascensão rápida e fácil, pela via da bandidagem (AMARAL, 2007a:106). 


\subsection{2 - A história do estudante HOMERO}

Homero tem 13 anos de idade, estuda na $7^{\mathrm{a}}$ série e está no colégio desde a $3^{\mathrm{a}}$ série. É magro, de estatura mediana para sua faixa etária, tem cabelos pretos, curtos e bem crespos, e olhos castanhos e francos. Foi escolhido pela coordenadora para ser entrevistado por ser do grupo dos "alunos com sucesso inconstante devido a problemas de comportamento". Em conversa com ele, o aluno conta-nos que antes havia estudado em uma escola metodista na favela da Rocinha, embora sempre tenha morado na favela do Vidigal. Nunca viajou, mas não soube dizer o lugar mais distante de sua casa onde já esteve. Além do colégio faz aula de futebol, três vezes por semana, desde os sete anos de idade. Acha que começou tarde a sua carreira de jogador de futebol, pois deveria ter começado a jogar com três ou quatro anos de idade. Adora a aula de Educação Física e não falta à escola. "Acho bom ir à escola, mesmo achando às vezes chato". Acorda sozinho com seu celular. Considera que o mais importante na escola é fazer os deveres, prestar atenção e ter educação. Para ele o melhor da escola é a divisão das matérias e poder fazer Educação Física no final do período e ir embora, sem entrar todo suado na sala de aula, aliás uma reivindicação de diversos alunos em outras pesquisas sobre a escola pública (cf. AMARAL, 2007). Homero quer ser jogador de futebol profissional, adora seu time, Flamengo, acha o Kaká o melhor jogador hoje em dia, mas o "Pelé foi o maior jogador do mundo antigamente”, como diz ele.

Contou que sempre gostou de brincar e jogar bola, mas que seus pais gostariam que estudasse, "pois, assim, ficaria esperto". As coisas mais importantes do mundo, para ele, são: "estudar e ter respeito com as pessoas". Segundo ele, seus professores o consideram inteligente e brincalhão. Seus colegas também acham que ele é brincalhão, e os da sua mesma idade gostam de "jogar futebol e estudar também". Demorou a responder sobre qual teria sido a maior mudança em sua vida, e preferiu deixar para responder por último. Acha sua família legal, ressaltando que gosta muito da sua mãe e das pessoas que o ajudam. Sua série mais fácil foi a $3^{\mathrm{a}}$ e a mais difícil está sendo a atual $\left(7^{\mathrm{a}}\right)$. Escola para ele lembra estudar - respeitar brincar na hora certa - prestar muita atenção na hora das aulas e não se envolver com a violência, porque alunos mais velhos batem nos menores. Gostaria de esquecer pessoas que se foram, e não quis dar maiores explicações, mas salienta que não quer esquecer de sua mãe. Acha que quando for adulto poderá jogar bola como profissional. Gostaria que, quando ele chegasse, a professora lhe dissesse: “olá, Homero tudo bem?”. 
Expôs que se fosse tirar um retrato da escola gostaria de tirar do pátio e das professoras. Finalmente, nossa conversa chegou então à maior mudança da sua vida: "perceber que eu tinha talento para jogar futebol porque eu fui jogar futebol muito tarde". $\mathrm{Na}$ sua casa moram seu pai, professor de futebol no Vidigal e numa faculdade; sua mãe, que trabalha em uma creche; e sua irmã mais velha (17 anos), que trabalha no centro e estuda à noite.

Durante o dia, fica na casa da avó materna, depois do colégio. Da janela da sua casa vê a praia de Ipanema e Copacabana, mas avisa que não dá para ver o Leblon. No fim de semana gosta de brincar com os amigos na rua, faz dever, e quando sai com os pais é para ir ao shopping, comprar alguma coisa. O melhor professor para ele é o que "sempre brincou (com ele), que não tem raiva de mim, sempre me ajudou".

Homero nunca trabalhou. Em sua casa ajuda na limpeza do quintal e cuida dos três cachorros, "limpando as coisas que eles fazem, dando comida e água". Sua irmã é responsável pelo banho deles nos fins de semana. Seus melhores amigos são os da comunidade onde mora. Sua avó materna, com quem passa as tardes, sempre morou no Rio, e o avô paterno também mora no Rio.

Nunca se envolveu com violência na escola, e se visse alguma coisa nesse sentido procuraria pela Diretora. Caso acontecesse alguma coisa errada com algum colega não deduraria, mas tentaria fazer com que o colega falasse. "Não acho certo dedurar, tem que contar a pessoa que fez", evidenciando o desenvolvimento do senso moral de reciprocidade que, se formos nos apoiar nas pesquisas de Piaget $(1932 ; 1994)$ sobre o Juízo moral na criança, já fora interiorizado. Não acha que colar faça parte da escola, porque "às vezes a pessoa acaba se dando mal, só vai ver as letras e não vai saber da matéria", afirmação que demonstra perceber as consequências negativas para a sua formação, de enganar a si próprio, "colando". Depreende-se de suas atitudes o desenvolvimento de relativa autonomia moral, que, segundo Piaget, depende de quanto o meio estimula a cooperação das crianças, tendo como princípios: a solidariedade, a autonomia da consciência e a responsabilidade subjetiva.

Em casa, gosta de ver reportagem na TV, e explica que não é “muito de música”. Às vezes, lê a parte de esporte do jornal que seu pai assina. Na perspectiva de Bourdieu, um dos muitos suportes materiais para a aquisição e/ou atualização de capital cultural. Homero diz que mexe bastante no computador, mas segundo ele, não entende muito porque não sabe 
"mexer na memória, nem mexer quando tem vírus". Seu pai, sua irmã e ele sabem manipular o computador, mas sua mãe "não sabe nem teclar".

Foi uma entrevista rápida e aberta para outros encontros. Ele demonstrou ser colaborador e mostrou disponibilidade para novas entrevistas: "é só avisar", que ele esperaria depois da aula.

Homero respondeu com firmeza, é um menino educado e aberto para o novo. Parece saber o que quer e tem uma meta a cumprir: ser um profissional em futebol.

É confiante na vida, mostrou que gostou de reconhecer coisas boas em si (talento para futebol), e que aprecia ser reconhecido (a professora cumprimentá-lo quando ele chegasse). Tem um senso moral bem desenvolvido, como no caso da cola e de não achar certo dedurar o colega.

\section{Desenhos:}

Sua sala de aula parece mostrar uma relação disciplinada com os colegas e com a professora. Esta olha para seus alunos, e estes estão virados para ela e o quadro negro. A sala está em uma disposição tradicional, com fileiras viradas para a frente, e a professora em pé ao lado do quadro-de-giz cheio de anotações. Tem noção de não poder brincar em classe, lugar com cadernos e livros sobre a mesa.

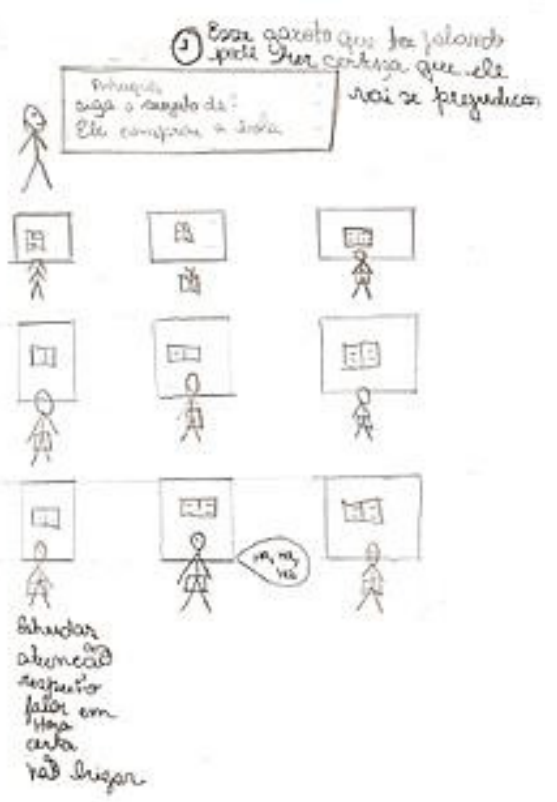

Seu desenho fora da sala de aula parece exercício do futebol, como em uma sala de mostrar o lugar central ocupado pelo futebol e dos colegas em sua vida. É um desenho que reproduz lugares definidos no aula, demonstrando como a ordem faz parte de sua vida e de como começa a entrar em contato com o sentido das regras 
para exercer um bom trabalho (tanto na escola, como no futebol, que é concebido seriamente por ele, como uma possibilidade de trabalho futuro).

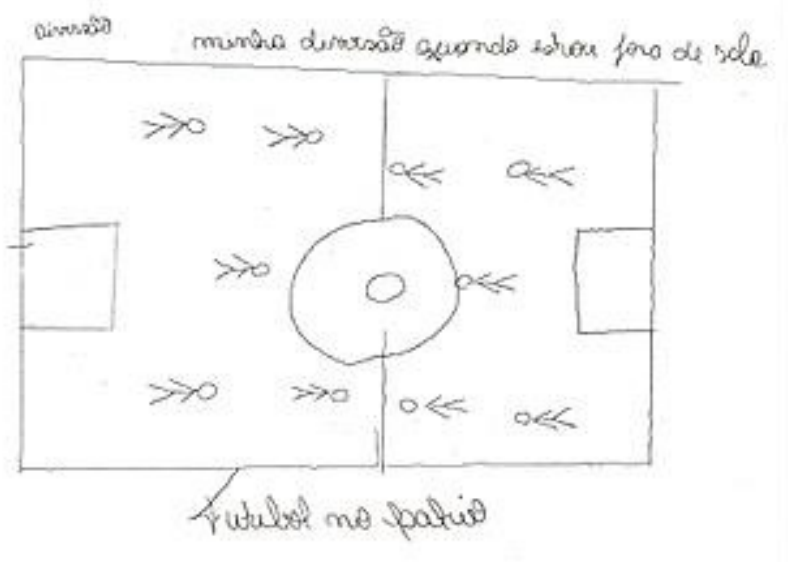

Seu desenho sobre a vida na escola parece exprimir sua necessidade de ajuda, por ser um aluno com um desempenho acadêmico inconstante; pela sua frase em relação a Diva, monitora (Perto dela eu me sinto muito esperto), acrescida da fala da coordenadora e de alguns dos seus professores: "Sozinho ele desiste no meio do caminho"

Fora da escola ainda aparece a questão de cumprir com uma tarefa, pois diz querer fazer a carreira profissional como jogador de futebol, talvez para satisfazer a expectativa paterna ou a necessidade de reconhecimento de suas capacidades, pois até por estímulo do pai, embora não só, conseguiu se dar bem nessa atividade.
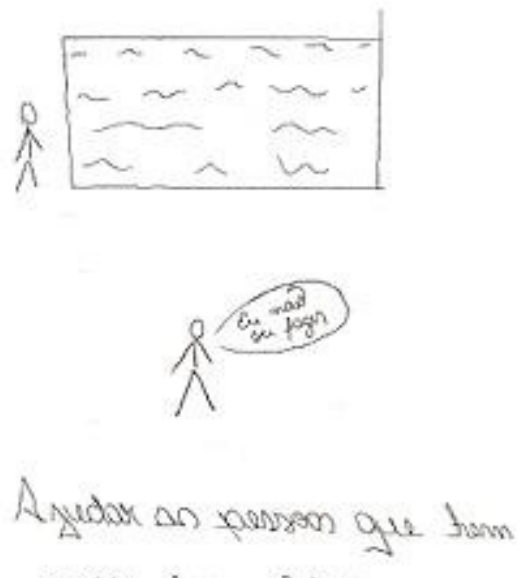
main depravdods.

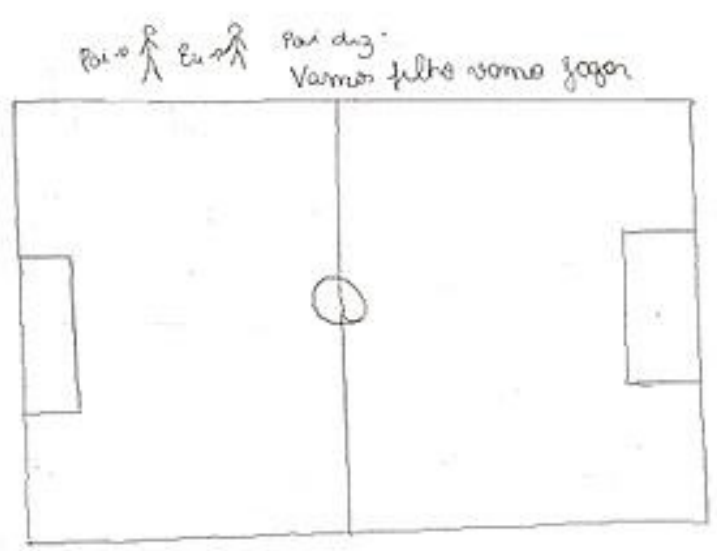


A dupla educativa é vivida com o pai que ensina a realidade da vida e acontece fora da situação escolar, o que é digno de nota.

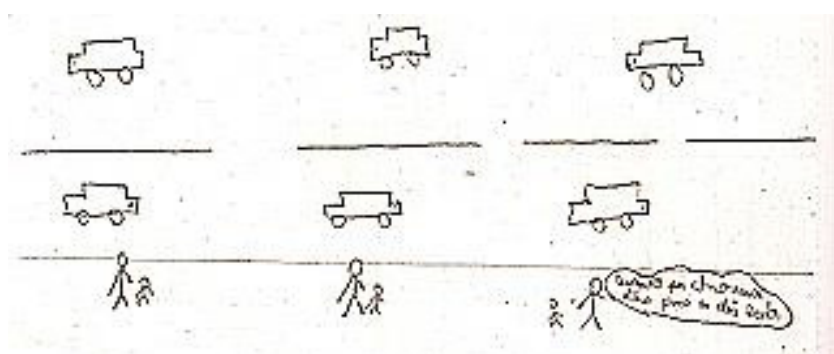

\section{O Subgrupo ${ }^{43}$}

DIVA: Perto dela eu me sinto muito esperto MIRIAM: Perto dela eu brinco muito com ela NARA: Eu não fico muito perto dela mais acho ela legal Eu: $\quad$ Eu me sinto feliz com elas

Homero parece saber distinguir perfeitamente as diferentes atuações dos colegas, pois percebe que Diva é uma boa aluna e demonstra que gostaria de se aproximar dela, porque se sentiria "muito esperto", enquanto com a Miriam seria mais na base de brincadeiras. Homero parece dizer que da "preguiça" de Nara quer manter distância.

\section{Coisas que eu sei que aprendi na escola: Homero}

- "Parar de bricar. Eu não conseguia, mas com a ajuda dos professores eu consigo para”

- "Bricar - Aprendi tomando alguns esporros mais aprendi a brincar na hora certa”.

- "Comportar - não me comportava brincava muito, mais hoje eu vejo se eu brincar muito posso repitir de serie, então só brinco na hora certa”.

Nas frases de Homero se pode depreender como a escola lhe deu limites, auxiliando-o a se conter para poder aprender.

\section{A representação dos professores e da coordenação acerca de Homero}

Os professores acham que Homero poderia ser um aluno melhor em relação aos seus estudos, embora o considerem esperto (no sentido de ser astuto, quando quer ludibriar o adulto e, no fundo, a si mesmo: "ele, podendo escapar do estudo, ele escapa". Tem atitudes de enfrentamento, seja com os adultos, seja com os colegas; esclarece, no entanto, que antes

\footnotetext{
${ }^{43}$ Textos na íntegra
} 
ele não era assim. Entrou no Stella Maris na $3^{\mathrm{a}}$ série, por muita insistência da mãe ${ }^{44}$. Sua irmã era aluna do colégio. Homero foi muito bem nas $3^{\mathrm{a}}$ e $4^{\mathrm{a}}$ séries e essa mudança de atitude aconteceu na $5^{\mathrm{a}}$. série, quando começou a ficar mais agitado, mas, segundo a coordenadora, sua irmã também era indisciplinada. Com a saída da irmã, no fim da $8^{a}$ série, ele tornou a se acalmar um pouco. É um estudante que poderia render mais do que rende, se ele se dedicasse mais. Mas os pais parecem ter muito cuidado com os filhos. "A mãe dele está sempre muito preocupada e chorosa em relação à filha mais velha, e o pai é bem falante", contou uma professora.

Ele é considerado rebelde, ou seja, é um menino esperto que poderia ser melhor se levasse a sério a escola, mas sua rebeldia atrapalha a aula e o grupo. Os professores ressaltam que ele é esperto no sentido de compreender com facilidade e ter notas boas, mas trata de se desvencilhar rapidamente das tarefas da escola que tem de fazer. É um menino que preocupa, porque, segundo alguns professores, escamoteia e já se envolveu em alguns episódios em que não assumiu o que fez. O Colégio trabalha a formação dos alunos para que assumam a responsabilidade pelo que fazem. Esse comportamento de Homero pode ser de resistência e, dependendo como se faz essa assunção de responsabilidade, denunciar um modo muito culpabilizante. Segundo a pesquisa de Amaral (2007), a criança pobre, quando se rebela, é contra a culpabilização de questões sobre as quais não tem controle, seja dela mesma, seja do ambiente.

Homero, para os professores, ao cumprir as tarefas muito mais por obrigação do que pelo prazer de aprender, demonstra desânimo com os estudos, parece não se envolver. Ele manifesta medo de compromisso. Apesar de tudo, demonstra ser uma criança madura, um pouco diferente dos coleguinhas da sala, que são mais infantis. Ele até foi bastante eficiente na $5^{\mathrm{a}}$ série, segundo a professora de Matemática:

\footnotetext{
"Eu não sei se é o momento, em que eu não tenho tanto tempo... Uma coisa é você ter cinco aulas com uma criança [como ocorre no Ensino fundamental I], outra coisa é você ter uma aula apenas, mas mesmo assim, estou achando ele menos motivado, ele chega e se desculpa, 'ah! me desculpa, mas eu não trouxe. Ah! Eu não fiz, de repente semana que vem, se eu trouxer ficará tudo bem?' (...) Homero não chega a ser rebelde, mas é um menino que eu diria que ele tem tudo para ser ótimo. Ele seria um bom aluno se não estivesse passando, seja o que for que ele esteja passando agora, que eu não consigo identificar exatamente, mas ele é um menino que tem "feeling", ele sabe onde está a coisa, ele tem como ultrapassar a barreira, é isso".
}

\footnotetext{
${ }^{44} \mathrm{O}$ colégio dá preferência para matricular os alunos na Educação Infantil. Nesse caso abriu uma exceção por ser irmão de aluna.
} 
Homero tem a coordenação motora muito bem desenvolvida, talvez porque tenha adquirido essa habilidade, praticando esporte com o pai na comunidade. Teve que se desligar do projeto de futebol no fim do $1^{\circ}$. bimestre, apesar de adorar fazer parte do projeto, porque ficou em recuperação em três matérias e teria que estudar todos os dias. Para continuar no projeto tem que recuperar as notas, essa foi a regra combinada desde sua entrada no projeto e é utilizada como"moeda de troca" para estimular os estudos.

\footnotetext{
"Ele até se esforça, mas desiste no meio do caminho. Talvez o Homero seja um caso para monitoria, sustenta a coordenadora, pois talvez, se ele ficar ao lado de alguém que suscite nele essa garra, essa vontade de conseguir, talvez ele vá longe. Sozinho ele desiste no meio do caminho".
}

"Homero é um aluno que daria no papel de malandro", define a professora de teatro. Essa imagem, que pode parecer preconceituosa, é justificada, segundo a professora, pela 'esperteza' de Homero para se livrar das tarefas. E acrescenta: “Ele é boa gente e participa do teatro e das propostas apresentadas".

Os professores se preocupam com Homero, pois veem que alguma coisa está acontecendo, mas que não sabem identificar. Apresentam a proposta da monitoria, mas o desligamento do projeto do futebol, de que ele gostava muito, em razão da regra de só voltar caso saísse da recuperação, parece não ter surtido o efeito desejado. O coordenador do projeto percebeu que Homero tinha talento para jogar futebol, o próprio menino sentia que era reconhecido por isso, mas o sistema educacional enfatiza e prioriza os estudos de disciplinas ligadas às ciências, ao desenvolvimento do raciocínio lógico-abstrato. É um modelo escolar que parece não motivar o estudante Homero e dar sentido a sua vida, uma vez que lhe foi retirado o que mais o ligava à escola - o futebol.

\section{Entrevista com C. - mãe de Homero}

A mãe de Homero completou o $2^{\circ}$ grau na escola pública do Vidigal. Ela relata que estudou até os 17 anos, depois parou e voltou com 32 anos para fazer o ensino médio, porque ela achou que fosse lhe fazer falta. Trabalha em uma creche particular com carteira assinada como auxiliar de recreadora e cumpre o horário das 10 às 19 horas. Acrescenta espontaneamente que gostaria de fazer uma faculdade, para ter o diploma e poder disputar uma mudança de categoria no trabalho. O mercado de trabalho valoriza o diploma e oferece melhor condição financeira para seus detentores, como sustenta a teoria de Bourdieu, segundo 
a qual, os títulos escolares fazem parte do que ele denominou de capital cultural institucionalizado.

Ela, o marido e um casal de filhos vivem com três salários, todos são cariocas e os avós também. Mora há 37 anos no Vidigal, tendo mudado de casa uma única vez. Contou que já viajou e conheceu Minas Gerais.

Sobre seu lazer, disse-nos que ultimamente não tem feito muita coisa, mas gosta de passear, de ir à praia, ao shopping, de dar uma caminhada. Há muito tempo não vai ao cinema, mas tem TV a cabo para ver filmes, gosta também do Jornal Nacional e de novela.

Disse que "o Homero já está numa idade que não sai muito comigo, mas ele é muito caseiro e gosta muito de futebol. Para ir às festas tem que mandar ir porque senão não quer ir também. Sai muito com o tio dele, mas de resto ele está em casa. É futebol e casa".

O tio leva seu filho às festas porque tem um filho quase da idade de Homero, e ele vai junto, "mas ele não é muito de sair não. Ele já foi ao Maracanã e ao Engenhão com o pai e o tio”.

Seu contato com a escola se dá mais nas reuniões, e salienta : "É muito difícil eu faltar numa reunião. Só se eu tiver algum problema”. Ela costuma ir às festas da escola quando os pais são convidados.

Tem muita expectativa em relação à escola, e comentou: "de uma escola eu espero tudo para o meu filho. O futuro do meu filho está garantido numa escola. Apesar de ele querer ser jogador de futebol, diz que quer estudar em outra escola para ter tempo de treinar. Eu falei não. Enquanto você não terminar, de lá você não sai”.

Parece que nem a escola e nem a mãe perceberam que o futebol participa da construção da identidade masculina, em geral, e, mais especificamente, de Homero, pois é a atividade pela qual ele se identifica mais com o pai e o tio. "Quer dizer que estava aprendendo a 'somar' com o pai, aliando-se a ele, para conquistar o reconhecimento de suas habilidades e, sobretudo, de seu crescimento perante uma comunidade mais ampla" (AMARAL, 2007a:113). Homero encontra no esporte uma forma de se 'narcisizar', uma ancoragem necessária para a sua identificação com o masculino, como salienta Amaral (2007a), um lugar social em que possa sentir-se partícipe de um projeto e que o ajude a enfrentar uma sociedade fragilizada pelo enfraquecimento dos limites e interdições, que 
desliza sem vínculos sólidos, nem possui tampouco bases emocionais estáveis. Homero atrai o interesse do pai para si, permitindo-lhe ir ao encontro do masculino e da definição da escolha de objeto, "sem o concurso da condenação moral e de preconceitos", como assinala (AMARAL (2007a:119). O esporte poderá ser, para ele, o meio de espelhar-se na tradição familiar e de dar contorno a si mesmo.

A mãe declarou que inscreveu Homero nessa escola na época da 'guerra'45 que começou na favela do Vidigal. Ela trabalhava na favela da Rocinha e ele estudava lá também, mas queria que ele fosse para o Stella Maris na $4^{\mathrm{a}}$ série. Ele acabou vindo na $3^{\mathrm{a}}$ série, devido à "guerra de facções do tráfico" que estourou lá. Ela saiu do emprego na creche metodista e conseguiu uma vaga para o filho no Stella Maris.

Homero nunca frequentou escola pública, mas a outra filha, sim. C. acrescentou que gostava muito de lá também. "Eu não sei agora que dizem que mudou. Tem pessoas que dizem que está boa e tem pessoas que dizem que mudou, mas eu sempre gostei de lá também, apesar de ser pública, mas eu sempre gostei muito daqui também. Isso aqui foi uma oportunidade para a gente que não tem nem como agradecer. Eu acho que o estudo abre portas para tudo", uma demonstração de como interpreta a abertura de uma escola particular para o atendimento praticamente gratuito para a comunidade. Depreende-se de seu depoimento que essa abertura da escola foi concebida como uma espécie de dádiva divina, sem que lhe passe a ideia, nem de longe, de que é um direito de todos ter acesso a um ensino de qualidade.

Comentou que o Stella Maris é uma escola muito boa "em tudo, em relação a tudo. A segurança das crianças e o desempenho e a estrutura também. O desenvolvimento, porque aqui tem não só o estudo, mas eles desenvolvem o futebol, tem cursos, tem toda uma oportunidade para fazer alguma coisa. Tem aula de reforço..."

Ao apreço pela escola, acrescentou: “O Homero não é uma criança que gosta muito de estudar não. Ele, se a gente não pegar fundo com ele, eu acredito até que ele não vá adiante não, mas o que a gente puder fazer para manter ele na escola ele vai ficar. Porque o Homero ele se distrai com tudo. Qualquer coisa, pronto, ele já pára. Ele não estuda. É difícil, não adianta botar ele para estudar porque ele enxerga a formiga que está passando lá no teto. Ele não tem concentração no estudo".

\footnotetext{
${ }^{45}$ Guerras de traficantes de drogas que disputam o domínio dos pontos de venda de droga nas favelas.
} 
Ela ajuda quando ele pede, mas, segundo ela, o pai não: “ele diz que não tem muita paciência, mas é porque Homero é muito distraído, mas também é difícil o Homero pedir ajuda", conclui.

O pai também completou o segundo grau e começou uma faculdade de Educação Física, mas teve que trancar porque tiraram o desconto que lhe havia sido dado e ele não podia pagar. "Aí complicou, ele teve que trancar e espero que ele volte logo".

A mãe deixa pronto o almoço, e a avó “está por perto e esquenta para ele”. Durante o dia, Homero está sempre lá ou está em casa sozinho.

Quanto à cultura, ela diz que entende alguma coisa, mas não sabe explicar cultura. Acha que cultura é muito o que a gente vive. O dia-a-dia.

Acha que o pai transmite cultura, "é muito mais específico para essas coisas", porque "o pai entende de muita coisa. Ele é uma pessoa que lê muito, ele é estruturado. Apesar das crianças acharem que ele é chato, ele está certo e ele conversa muito com as crianças". Esta é provavelmente uma das razões para o garoto se aproximar do pai, por considerá-lo seu grande instrutor, uma vez que deve ensinar, conversar e formá-los para a vida e para o futebol. Enfim, por talvez lhe conferir uma formação mais viva do que a escola.

É interessante a concepção de cultura da mãe, que se confunde com o que Kant ${ }^{46}$ (1788) chamou de razão prática, ou os usos e costumes de um dado grupo social ou comunidade. C. considera que a convivência em casa, a organização da sua casa, sua maneira de viver no mundo, isso tudo é cultura que está transmitindo para seus filhos. "Que está difícil de entrar na cabeça deles", e desabafa: "é muito complicado a gente tentar passar as coisas. Eles não querem entender. Acha que a gente é velho e está ultrapassado".

Lembrou que seus pais lhe ensinaram o sentido da educação: "Com certeza comportamento. Como lidar com as pessoas, respeito. Eu acho que isso é muito importante na nossa vida. Porque respeitando o próximo, se todos respeitassem o mundo seria muito melhor, não é?"

Na escola, aprendeu também respeito, educação. Acha que não teria seu trabalho e sua profissão se não tivesse ido a escola. C. vem de uma família que sempre teve o trabalho

\footnotetext{
${ }^{46}$ KANT, Imanuel. Crítica da Razão Prática (1788)
} 
como princípio norteador de suas vidas: sua mãe trabalha em casa de família e seu pai trabalhava para a prefeitura.

A mãe de Homero sonha em ter uma casa própria, seus pais já têm. Para o filho, ela deseja que ele faça faculdade e escolha uma boa profissão, pois gostaria muito de vê-lo formado.

C. nos contou sobre sua percepção da diferença entre os jovens de sua geração e os jovens dessa época: "Acho o mundo muito diferente da época que tinha a idade de Homero. As diferenças são muitas. Na minha época, quando minha mãe falava era lei, não precisava nem falar, só olhava e a gente estava respeitando, já abaixava a cabeça. E agora, os jovens de hoje em dia, você fala, fala, fala e é complicado. Eles não escutam”, diz ela.

Homero parece contar com os pais, figuras parentais capazes de lhe oferecer um apoio seguro para o seu crescimento, conforme assinala Amaral (2007a). 


\subsection{3 - A história da estudante: MIRIAM}

Miriam tem 12 anos de idade, estuda na $7^{\text {a }}$ série e está no colégio desde a Classe de Alfabetização - CA. É uma morena bem apessoada, tem cabelos bem crespos, presos em um rabo de cavalo. Ela é magra e menor em altura que seus colegas. Tem uma expressão séria ampliada pelo uso de óculos que lhe dão uma aparência severa. Foi escolhida pela coordenadora para ser entrevistada por ser do grupo dos "com fraco desempenho". Em conversa com ela, soube que antes havia estudado em uma escola cujo nome não lembrava (Escola Municipal Marechal Hermes no Humaitá). Gosta de passear, de ir a Copacabana e Ipanema com a mãe. Para ir à escola, Miriam acorda com o celular, e não falta porque gosta, mesmo achando que "às vezes é chato". Gosta de prestar atenção às aulas e fazer seus deveres. Acha que o melhor da escola é a amizade com os professores.

Ela relatou que tinha aula de vôlei gratuita, no colégio, fora do horário escolar no ano passado. Esse ano não vai fazer e não explicou o motivo, por mais que insistíssemos. Como é o mesmo professor do projeto de futebol, intuímos que ele use o mesmo critério para as aulas de vôlei, ou seja, notas baixas: afastamento temporário do projeto até recuperá-las. Miriam diz não fazer nada fora a escola. Mora na casa com sua mãe e seu pai e sempre morou no Vidigal, em cima de um bar que o pai explora. Na volta da escola seus pais estão ou em casa ou no bar.

Miriam entrou na escola em 2000. Não tem lembrança da primeira impressão que teve quando entrou na escola, mas lembra o nome da primeira professora. Considera-se uma aluna mediana porque tem dificuldade em Matemática, mas nunca repetiu o ano. Diz ser aluna de "nota 7 para cima". Quando precisa de ajuda pede à tia, que é irmã da mãe e que mora perto da sua casa. Não pede para a mãe porque ela não estudou muito, "talvez até a $\sigma^{a}$ série", e o pai “não tem tempo porque ele trabalha muito". A casa onde moram é alugada. Tem 2 quartos, banheiro, sala e cozinha. Da janela da sua casa vê várias pessoas subindo e descendo a favela.

Elenca o que mais preza em sua vida: a mãe, o pai, a família, ser uma pessoa boa e honesta. Sua família extensa mora no Nordeste: os avós, tanto os maternos como os paternos. Estes moram em Pernambuco, na cidade de Timbaúba, onde Miriam nasceu. Ela veio com os pais com um ano e meio mais ou menos, para o pai "conseguir um emprego bom".

Para ela, seu pai é mais bravo que sua mãe porque, "quando fica bravo, berra muito $e$ fica emburrado". Para Miriam, a maior mudança em sua vida foi quando um primo, da sua idade, mudou-se para o Nordeste e ela ficou "sozinha com a mãe e o pai". Disse que chegou 
a ficar doente, "não queria comer nada". Nessa época tinha 9 para 10 anos. O primo morava ao lado da sua casa e foi embora com a mãe, mas voltaram um ano depois. Ele agora tem 13 anos e voltou a morar no Vidigal também. Para ela sua família é ótima, só diz querer esquecer as brigas que teve com as amigas e com o primo, mas não quer esquecer quando está com as pessoas que gosta (ou seja, quer preservar os momentos bons). Nos fins de semana, anda de bicicleta com a mãe, a tia e os primos no Leblon ou vai à praia do Vidigal. Nunca trabalhou e ajuda em casa, lavando louça e varrendo a casa, "e só"! Arruma a sua cama só nos fins de semana.

Quando for adulta, Miriam acha que poderá trabalhar em alguma coisa da qual goste. Considera-se uma boa pessoa. Seu dia começa com um banho, escovar os dentes; sai sem comer nada e no recreio come um salgado. Vai embora da escola sozinha, almoça a comida que pega no bar, descansa e vai para a casa da tia para ajudar nos cuidados com a prima de 2 anos de idade. Fica lá até mais tarde, mas não sabe dizer até que horas. Volta para fazer o dever e ver TV: gosta de desenho e de todas as novelas globais que assiste com sua mãe. Faz o dever no quarto, ou na cama ou na mesinha. Tem TV no quarto. Gosta de ler "gibi" da Turma da Mônica e, às vezes, lê livros. "Só eu que leio", observa, em comparação com seus familiares. Os livros ficam na estante da sala. Ela compra revistinha com o dinheiro que seu pai lhe dá, mas a banca de jornal mais próxima de sua casa fica no Leblon. Lê o jornal Extra, algumas vezes na casa do seu tio, que mora ao lado da tia.

Observe-se como a falta de acesso aos meios de informação lhe fazem falta: não há uma banca de jornal por perto e não frequenta a biblioteca, o que poderia lhe dar parâmetros diferentes dos que tem hoje, uma vez que não há mais ninguém que leia algo ao seu redor. Em todo caso, lê o jornal voltado para as camadas populares e com preço acessível e faz as lições com a ajuda da tia. E, como veremos, também seu acesso a outros meios de veiculação cultural são restritos: Miriam contou que nunca foi ao cinema, e lembrou-se da única vez que foi ao teatro quando era pequena. Não tem computador, mas tem celular que usa para falar com as amigas ou com a tia e a prima. Seu primo e sua prima são seus confidentes das coisas boas ou ruins que lhe acontecem.

Miriam nos relatou ainda que sempre gostou de estudar, de jogar vôlei e futebol. Seus pais gostariam que ela estudasse e se divertisse. Miriam costuma entregar seu boletim e os avisos de reuniões a sua mãe, que vai às reuniões. Seu pai conhece a escola porque "vai comprar livro", mas nunca foi a uma reunião. É a sua mãe que acompanha seus estudos, 
sempre perguntando sobre a escola. Algumas vezes seu pai também pergunta, mas é a mãe que "reclama" se ela não estuda.

Miriam acredita que se estudasse conseguiria ter um bom emprego, demonstrando, do mesmo modo que seus colegas entrevistados, como lhe é importante a escola em sua vida.

Para ela, seus professores acham que ela é quieta, um pouco inteligente e esforçada. Seus colegas também acham que ela é quieta. Segundo ela, os garotos preferem baile funk e mexer no computador, e as garotas também. Seus pais não deixam que ela vá. Para ela as séries mais fáceis foram a $2^{\mathrm{a}}$ e a $3^{\mathrm{a}}$, e a mais difícil está sendo a atual, mas achou a $6^{\mathrm{a}}$ difícil também. Associa a escola a "fazer amizade, ser educado", e para por aí, pois não consegue encontrar cinco coisas que poderia dizer sobre a escola. Se tirasse dois retratos da escola, tiraria um perto da estátua da Imaculada Conceição, no pátio, e outro da sala do TOC, que é um lugar de oração e de cantar música religiosa. Não sabe dizer o que significa TOC $^{47}$.

Para ela, o melhor professor é o que sabe explicar bem e dar atenção a todos os alunos. Seus amigos são da escola e os da família também. Gostaria que, quando fizesse uma prova, o professor comentasse com ela uma boa nota alcançada. Se pudesse escolher só uma matéria para estudar na escola seria Português ou Ciências, mas tiraria Matemática.

\footnotetext{
${ }^{47}$ Tempo de Orientação Cristã conforme informação obtida na secretaria.
} 


\section{Desenhos:}

A sala de aula de Miriam parece mostrar um lugar vazio, sem professor, um quadro com um conteúdo indecifrável, e a aluna pequena e sem olhar para a professora.
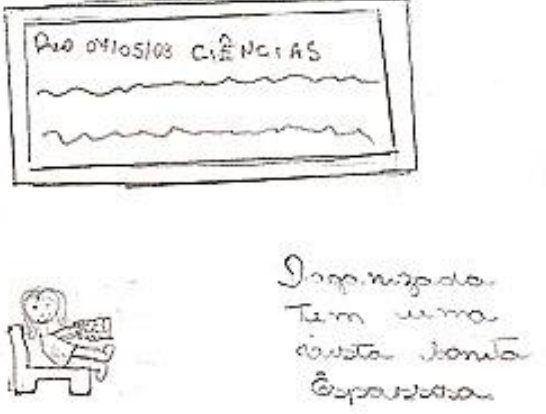

Seu desenho ganha vida fora da sala de aula, com um pátio com vários alunos brincando e jogando, representado como um ambiente propício à socialização.

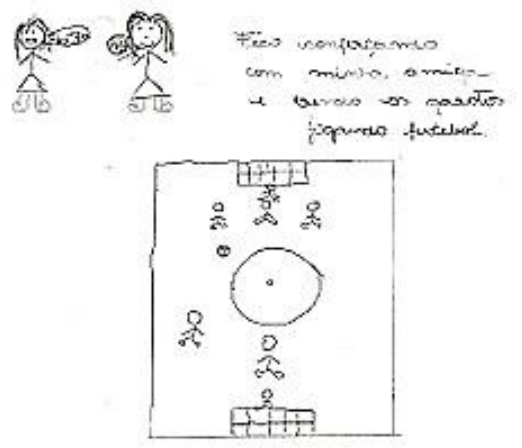

A vida na escola parece anunciar um lugar onde Miriam se sente só diante do conteúdo escolar.

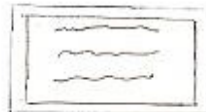


Do mesmo modo que a vida fora da escola mostra essa mesma solidão (ou ficando em frente à TV ou observando o jogo de futebol dos garotos, como se não tivesse um espaço próprio de brincadeira, ou mesmo de estudo).

$\mathrm{Na}$ dupla educativa ela desenha uma professora próxima, expondo, desse modo, talvez o seu desejo, mas o apaga e a coloca distante, expressando como de fato ocorre a relação professor/aluno, apontando $\mathrm{o}$ conteúdo do quadro (cujo ensino é tão valorizado pela comunidade, em razão da baixa qualidade do ensino público ao qual tiveram acesso até entrarem na atual escola). Miriam talvez queira ser vista, porque em todos os desenhos ela dirige o olhar para fora do papel, o que causa a impressão de ansiar fazer contato com o mundo adulto.

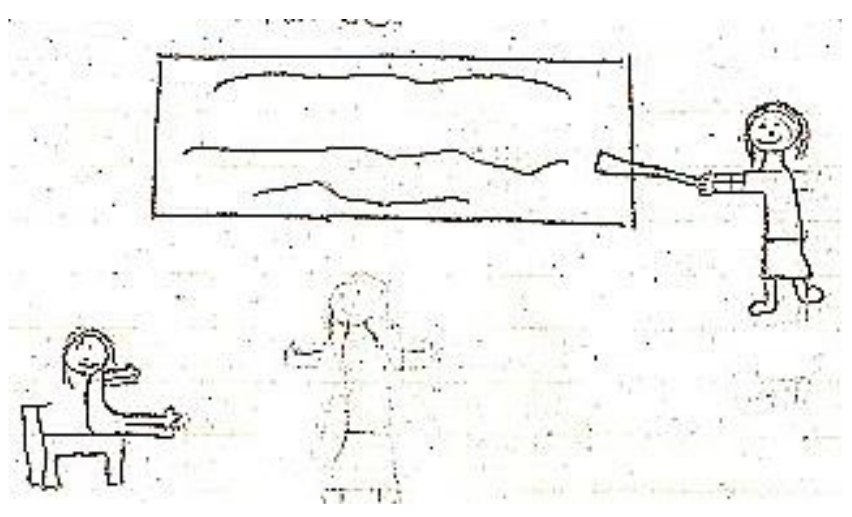

\section{Sub-grupo escrito por Miriam ${ }^{48}$ :}

- A DIVA é muito legal e alegre nós ajuda quando precisamos sempre quando vamos falar com ela ela nos da atenção.

- O Homero é engraçado sempre quando pode nos ajuda

- A NARA e muito legal ela conversa muito com todos nos. Nos ajuda quando pode.

- Eu acho que sou legal do atenção a todos me do muito bem com todos

Miriam é mais nova do que Diva e Homero, que estão conseguindo acompanhar melhor o ensino. Sua observação dos colegas é apurada, coerente com as observações feitas por eles mesmos, pelos colegas e professores. Na observação feita em sala de aula, Miriam é mais amiga dos meninos do que das meninas. Observamos que saía da sala de aula sempre acompanhada de dois colegas e, no pátio, ficava com eles também.

\footnotetext{
${ }^{48}$ Textos na íntegra.
} 


\section{Coisas que eu sei que aprendi na escola: Miriam}

Eu aprendi a escrever por que e importante para mim

Eu aprendi a brinca porque aprendi a brincar na hora certa

Eu aprendi a ser feliz porque estou com meus amigos

\section{A representação dos professores e da coordenação acerca de Miriam}

Os professores dizem que Miriam tem várias dificuldades. É preciso empurra-la para Miriam se mexer, senão ela para e se acomoda. Miriam é uma aluna que não faz enfrentamento nenhum, é uma aluna cordata, séria, mas precisa de ajuda para caminhar. É um padrão de aluna com sérias dificuldades, descrita como "meio parada, meio frágil".

Custa-lhe dar uma resposta, o que, segundo os professores, revela sua dificuldade de entender o que é dito. . Este tipo de situação é mais frequente nas ciências exatas. "Ela fica olhando, olhando para o professor e parece que esse olhar quer sugar o que está sendo dito, mas mesmo atenta ela não consegue dar uma resposta". Para os professores, Miriam percebe que tem dificuldade.

Para a professora de Ciências Exatas, Miriam certamente é uma menina com dificuldade, que se expressa de maneira reservadíssima, tem receio de se posicionar e já deveria há muito tempo ter parado para rever os conteúdos. Ela é bastante esforçada, tem vontade de acertar, mas como tem uma "dívida enorme" (uma lacuna no conhecimento) 49 em termos de conteúdo, ela não consegue e não acompanha. Ela é uma aluna que não traz qualquer tipo de problema em sala de aula, sempre está com o material, faz as coisas, mas ela absolutamente não responde a nada do que é esperado. A professora manifesta compaixão . Faz dela a seguinte imagem: "Para ela pode-se ensinar um caminho, mas no desvio ela não vai saber para onde ir, porque tem dificuldades para tomar decisões". Quanto à socialização, Miriam fez progresso, pois era muito tímida, mas está desabrochando. Ela se entrosou muito bem na turma. Ela era uma menina que era deixada de lado e agora está bem mais participativa, e o esporte contribuiu para isso.

Alguns professores acham que quando ela sente que estão chegando perto dela, ela agride, se recusa a ler e se fecha como uma ostra. "Aí ela abre, mas abre para te agredir. Ela se torna totalmente diferente". Nessas circunstâncias, Miriam parece se sentir ameaçada e

\footnotetext{
${ }^{49}$ Dubet denomina de "lacunas que se acumulam" (1997: 230)
} 
abatida em sua auto-estima, uma vez que não está conseguindo acompanhar adequadamente o que é dado, e esboça essa reação para se defender. Sua conduta parece expressar a revolta, ou a injustiça da professora por não entender e não ajudá-la no que ela precisa. Tal constatação por parte do professor favorece a indicação para uma turma de reforço escolar ou encaminhamento para um atendimento psicopedagógico.

Miriam não tem facilidade de comunicação entre os amigos e se dá melhor com meninos. A família não comparece muito à escola, e as professoras não sabem como é sua estrutura familiar.

\section{Entrevista com M. - mãe de Miriam}

A mãe pediu que não gravasse a entrevista porque acha "um pouco vergonhoso". Contou que não chegou a terminar a $5^{\mathrm{a}}$ série: "Não quis e não me interessei”. Sabe escrever, mas acha difícil, só lista de compra. Falou que também não "é de ler livro, às vezes, mas pouco". Diz ser "fissurada em ser dona de casa" (talvez como uma forma de se refugiar do enfrentamento de suas próprias dificuldades de aprendizagem que hoje atingem sua filha?). Não sai para lazer. Vê televisão: novela, Jornal Nacional e filme. Tem TV a cabo, mas não tem computador. Ela mora numa casa com o marido e a filha. Vivem dependentes do movimento do bar, às vezes tiram um salário e meio por mês.

Só o marido trabalha no bar, ela não trabalha fora. Faz 20 anos que mora na favela do Vidigal. Veio de Pernambuco já casada, e com Miriam com três meses, em busca de emprego. Nunca saiu do Rio de Janeiro: "só indo para Pernambuco e voltando. Fica no vai e volta. Sou doida para ir embora". Tem mãe e pai lá e lamenta: "estou longe da velhice deles". Tem um casal de irmãos que moram no Rio de Janeiro também.

Disse que nunca vai à escola porque a filha passou a vir sozinha da $5^{\mathrm{a}}$ série em diante. Fez questão de dizer que moram pertinho da escola. Mas se a convidam para as festas ela vai, embora deixe claro que o convite não vem sempre, demonstrando relativo interesse em frequentar mais o ambiente da escola onde sua filha estuda.

Sua expectativa em relação à escola para sua filha é de que ela aprenda, se desenvolva e aprenda a tratar bem as pessoas: 
"uma escola já diz tudo, já é para aprender, vir para estudar mesmo. Antes daqui ela estudou no Jardim, em Botafogo, não lembro o nome. Que diferença! Nossa! Estudos totalmente diferentes. Meu sobrinho estuda lá, o dever é diferente, o professor faltava muito, adorei quando abriram aqui para a comunidade. Miriam vinha de ônibus para casa e chegava de noite. Antigamente a escola pública era melhor do que agora. Os alunos não querem nada da vida. Quero para Miriam um futuro bom, para a minha filha. Que estude, aprenda para fazer uma faculdade, vou fazer de tudo para ela conseguir fazer uma faculdade".

Observe-se que o ideal de escolarização que a mãe almeja para sua filha é alto, embora na prática faça pouco por isso: não é ela que a ajuda nas lições, embora só tenha essa filha, a menina passa toda a tarde na casa da tia.

Disse ainda que era difícil "explicar cultura para ela. É participando das aulas que tem na escola, fazendo inglês, frevo, festa junina". E ela pediu "Me explique o que é cultura que depois eu continuo. São modos de ser. Em Pernambuco as pessoas são mais amigas, aqui não sabe quem é seu amigo quem não é. Em Pernambuco é melhor, mas não tem trabalho. Se tivesse aonde trabalhar... Sai de lá para escolher uma coisa melhor. Tentar né!"

É interessante como ela, uma pessoa com forte enraizamento no nordeste, concebe cultura não apenas como a cultura obtida na escola, mas também as culturas populares e o modo de ser do povo, ou seja, seus usos e costumes. Uma concepção que, se fosse aproveitada pela escola, talvez aproximasse mais mãe e filha dessa escola.

Declarou que aprendeu com os pais a respeitar as pessoas, nunca pegar nada de ninguém. Já na escola disse nem lembrar o que aprendeu, "pelo muito tempo que já passou. Ler e escrever eu aprendi, pelo menos esses dois eu aprendi”. E concluiu: "Ter cultura serve, que serve, serve, só não sei para quê!”, demonstrando assim o distanciamento da cultura escolar do universo cultural dessa mãe. Isto pode ajudar a compreender por que a garota talvez se sinta um tanto quanto alheia àquilo que lhe é ensinado na escola. 


\subsection{4 - A história da estudante: NARA}

Nara é uma menina de 12 anos de idade, a mais jovem dos quatro alunos entrevistados. É estudante da $7^{\mathrm{a}}$ série e está no colégio desde a Classe de Alfabetização. Tem a tez e os olhos claros, cabelos compridos, sendo de constituição forte e robusta. Foi escolhida pela coordenadora como aluna "sem investimento escolar". Estudava na creche que fica na favela do Vidigal. Nara mora lá em cima da favela ${ }^{50}$ mas só vai para casa à noite, quando sua mãe chega do trabalho. Ao sair da escola, Nara vai para a casa da avó paterna onde fica até à noite. Muitas vezes fica para dormir, "porque é bom" e não vai para sua casa porque senão fica sozinha. Conta que sempre morou com a mãe na mesma casa no Vidigal, na parte de cima. No térreo, moram seu avô materno, a mulher dele e uma tia.

Sua mãe trabalha no comércio como demonstradora de produtos de beleza. Nara acha que a mãe estudou até o $2^{\circ}$ ou $3^{\circ}$ ano do Ensino Médio, mas não tem certeza porque "não pergunta sobre essas coisas". Não soube responder sobre o grau de escolarização de sua avó materna, mas diz que ela sabe ler. Nara entrou para a escola na Classe de Alfabetização - CA - porque sua mãe preferiu que ela só mudasse de escola quando fosse ser alfabetizada, explica Nara. Gosta da escola e se fosse tirar uma foto tiraria da sala de aula e do pátio. Nunca trabalhou e ajuda algumas vezes no trabalho doméstico, só que normalmente, depois do almoço, vai direto para o computador onde fica a tarde toda. Divide o computador com os primos na casa da avó paterna, por isso tem horário para usar.

Seus pais são separados desde quando tinha entre 6 e 7 anos. Seu pai mora em Madureira com outra mulher. Às vezes ela vai para lá. É filha única de ambas as partes. Da janela de sua casa "vê tudo", isto é, a praia, o Leblon e parte do Vidigal. Já da janela da casa da avó paterna, onde fica a maior parte do tempo, diz que não acontece "nada de importante, só (vê) as casas dos outros”.

Nos fins de semana, gosta de ir para a casa da outra avó, que mora na favela da Rocinha com o marido, porque ela tem uma filha com uma filhinha de 3 anos. Nara gosta muito da garotinha e vai para a casa de outras pessoas da família que moram perto. A viagem mais distante que fez foi para Cabo Frio. Sempre vem a escola e gosta de vir. Disse que pratica vôlei de praia no Leblon, três vezes por semana. Não tem celular, mas sua mãe tem e ela acorda com o celular dela. Quer ir a escola para aprender as coisas. Para ela, o melhor da

\footnotetext{
${ }^{50}$ A parte de cima da favela é menos valorizada, segundo o mercado informal imobiliário.
} 
escola são os amigos e as amizades. Quando crescer quer ser fisioterapeuta para cuidar das pessoas. Conhece essa profissão porque teve que fazer fisioterapia quando quebrou a perna em 2006. Pode-se intuir que foi bem tratada pela identificação que fez com o modelo.

\section{Desenhos:}

Na sala de aula de Nara observa-se a presença de amigos, conteúdo escolar na lousa, e a professora, que ela situa recuada, parecendo mostrar que a importância está na conversa com os colegas.

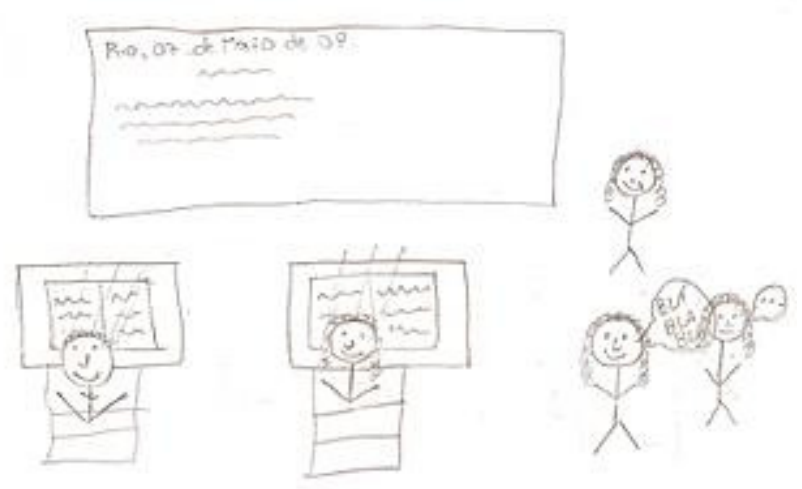

Fora da sala de aula é possível falar muito, segundo ela.

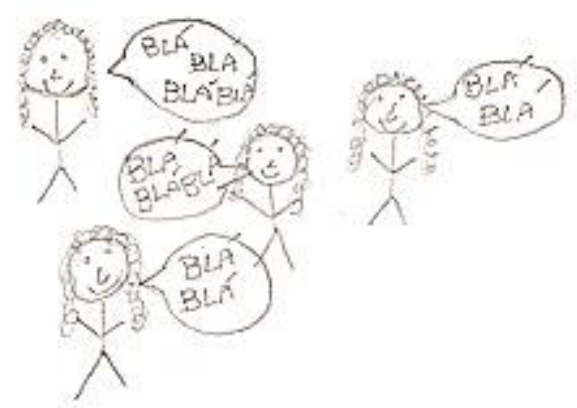


A escola parece ser um lugar divertido, equiparada à vida que tem fora da escola, onde encontra outros amigos com quem brinca de pular de corda, vôlei ou por meio do "orkut" no computador. Seus desenhos têm movimento e são bastante expressivos.
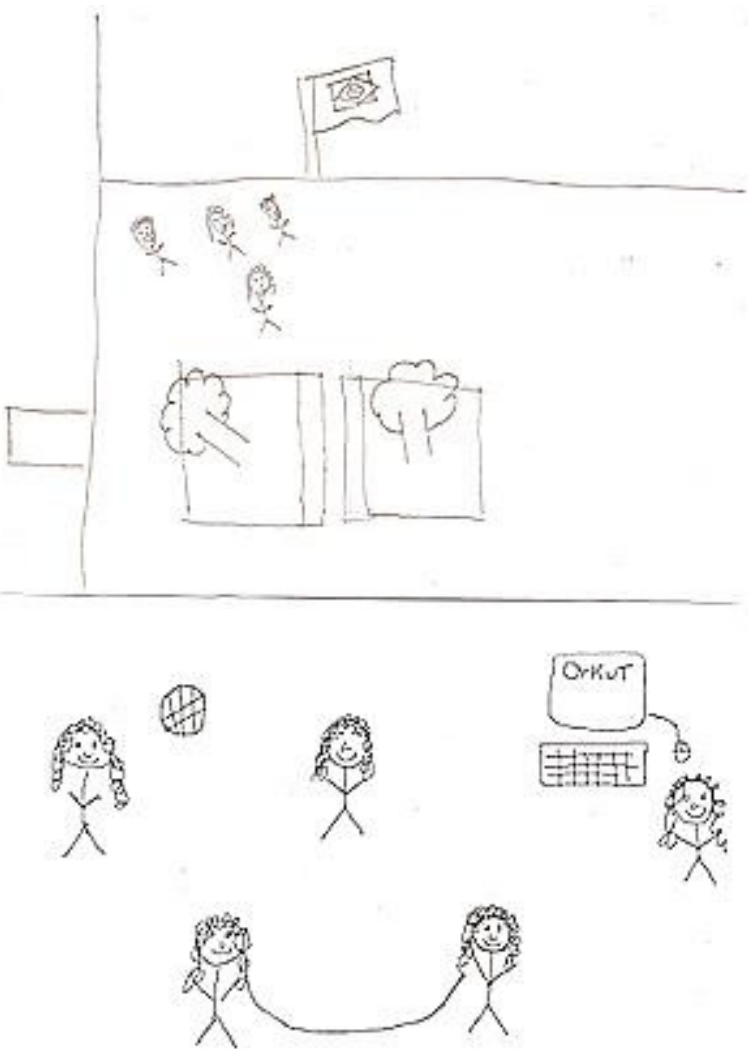

Na dupla educativa parece mostrar que aí é a vez de falar da professora, e é o único desenho onde fica sozinha sem os amigos.

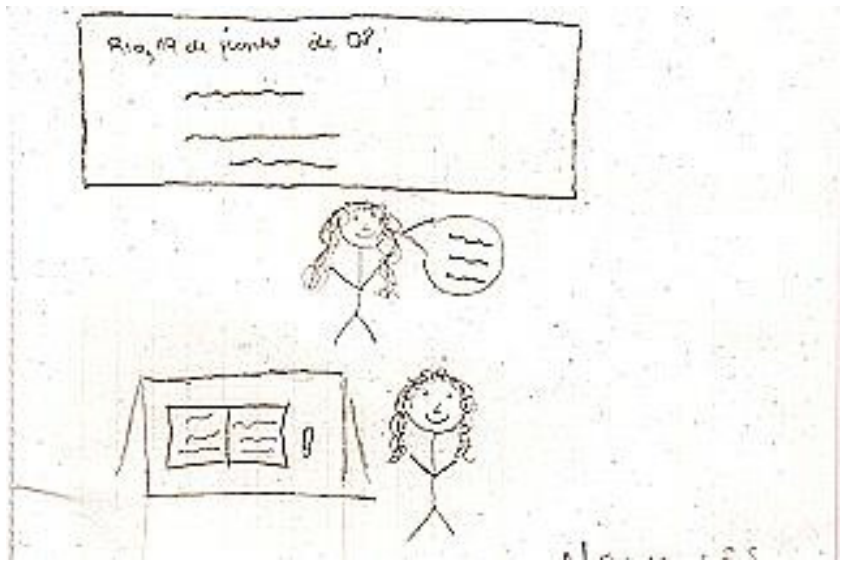




\section{O Sub-grupo escrito por Nara ${ }^{51}$ :}

Eu: Penso em ser alguém na vida. Estudar. Ter filho.

Homero: Pensa em ser jogador de futebol

MIRIAM: Pensa em ter sua casa própria

DIVA: pensa em ter sua banda de rock bem legal

Como se pode depreender da visão que tem de si e dos amigos, parece identificar projetos próprios de cada um, e bem definidos.

\section{Coisas que eu sei que aprendi na escola: Nara}

Eu aprendi Algebra comecei a entender agora. Porque esto prestando mais atenção. Aprendi Ed. Física por que me dou bem fazendo atividades.

Aprendi a conversar na hora certa pra presta atenção na aula

Esta última frase é recorrente, demonstrando o trabalho feito pela escola com os alunos para obter algum nível de disciplina em sala de aula.

\section{A representação dos professores e da coordenação acerca de Nara}

Os professores comentaram que Nara tem muita dificuldade. É educada, não costuma ter nenhum tipo de enfrentamento, é cordata, alegre. Consideram-na um padrão de aluna mais com preguiça do que com dificuldades ou com problemas de disciplina.. Poderia ser uma boa aluna, mas não investe. Os professores acreditam que, se ela se esforçasse, conseguiria. Por exemplo, a escola oferece aula de apoio, uma hora por dia, fora do horário escolar, mas a menina não vem. Nara precisa que a empurrem, que lhe digam "vem para a aula de reforço que você precisa, não esquece, precisa ser lembrada. É uma menina que ri e brinca e não atrapalha a aula, mas não tem interesse”.

A mãe de Nara só vem quando muito solicitada, mas, segundo a coordenadora, é cuidadosa com a filha. No entanto, tem que trabalhar o dia inteiro fora, e Nara não conta com

\footnotetext{
${ }^{51}$ Textos na íntegra
} 
seu pai no convívio diário. A mãe parece ter um poder aquisitivo melhor, porque já mencionou ter arranjado uma professora particular, uma "explicadora", conforme elas dizem.

A Direção chamou a mãe para avisá-la de que Nara estava precisando de aula de apoio oferecida pelo colégio, mas a "mãe trabalha o dia inteiro, diz que vai falar, mas a menina não veio". A diretora não sabe dizer se a família fala e a menina não obedece ou se a família nem toca no assunto.

Nara é uma aluna que não responde ao esperado pela professora, mas é uma menina com presença e que sabe defender os seus pontos de vista. "Ela traz uma 'dívida enorme', em termos de conteúdo, mas não há uma busca realmente para suprir e desfazer esse buraco que existe". Para essa professora ela é oportunista, se tiver a oportunidade de se dar bem, ela vai fazer. "Ela, provavelmente, não sabe fazer o trabalho, ela vai ver um coleguinha que fez e ela vai copiar integralmente e entregar. Nara é preguiçosa, mas mais oportunista. Se o mundo abrir a porta para ela, ela vai saber aproveitar a oportunidade, ela não é boba".

Parece existir uma visão preconceituosa dos professores em relação aos alunos que não têm um bom rendimento escolar, pois consideram um distúrbio de caráter o que poderia ser visto como busca de um caminho mais fácil, no caso de Nara, por exemplo, talvez por insegurança ou até por se achar incapaz de corresponder ao que esperam dela de rendimento.

De acordo com outra professora: “A Nara era tímida quanto à socialização, e o esporte contribuiu para ela se relacionar. Nara atualmente não está mais muito interessada, porque já amadureceu 'um pouco demais'. Era uma menina muito certinha e agora ela já está descobrindo a rebeldia, e ela que participava de todas as atividades agora questiona mais".

Ainda outra professora disse o seguinte a respeito dela: “É muito simpática, sorridente, o tempo todo. Ela tem muita dificuldade. É aquela aluna que, por exemplo, fala: professora, pode deixar que vou trazer na próxima aula, mas ela não traz, e deixa para lá”.

A professora de Artes crê que "com ela as coisas vão acontecer muito devagar no sentido de despertar um canal de comunicação, apesar de ela não ter dificuldade de relação, mas é tímida. Muito presinha, muito contida, mas é um doce de menina. O grande desafio é ela estar lá no espelho se olhando, se admirando, mas com uma forcinha, um estímulo, ela tem potencial para poder abrir uns canais. Não é aquela aluna que não quer fazer e pronto. Sabe do modo dela e dá seu recado do jeito que pode”. Neste depoimento podemos 
depreender uma visão mais acolhedora (???) da menina, uma possibilidade de identificar tanto suas dificuldades, como suas potencialidades.

\section{Entrevista com C. - mãe de Nara}

A mãe de Nara concluiu o segundo grau em 1994 e, no ano seguinte, ficou grávida e Nara nasceu. Depois começou a trabalhar e diz que a partir de então: "Aí não sobra tempo nem dinheiro". Ela e a filha vivem com uma renda por volta de $\mathrm{R} \$ 565,00$ e moram na favela da Chácara do Céu.

C. relatou que veio morar no Vidigal com 2 anos de idade e nunca mais saiu de lá. Sua família (pais e irmãs) mora perto. Seus pais são da Paraíba e começaram a vida familiar no Rio. Ela não conhece a terra natal de seus pais, mas já viajou a passeio para Minas e São Paulo.

Trabalha como vendedora de produtos de beleza em um shopping todos os dias das $9 \mathrm{~h}$ às $18 \mathrm{~h}$, e domingo é sua folga.

Acrescentou que Nara, depois da $5^{\mathrm{a}}$ série, passou a andar sozinha normalmente, então ela não tem que levar a escola e buscar, até mesmo porque seu horário de trabalho não permite. Mas, como a avó paterna mora bem próximo do colégio, Nara fica durante o dia na casa dela. O pai mora no subúrbio de Rocha Miranda há algum tempo.

C. diz que acompanha a vida escolar da filha, sempre indo às reuniões do colégio e às festas: "Quando é liberado, às festas eu procuro vir", referindo-se ao momento em que a escola se abre para a comunidade.

Ela tem claro o motivo da escolha dessa escola, ao afirmar:

"Pelo fato de o ensino ser bem melhor do que as escolas que têm aqui próximas. Aqui ela aprenderia muito mais de um jeito, é, por causa das irmãs seria um ensino mais assim, como vou explicar, pelo fato da doutrina religiosa, dos ensinamentos, não só em aprender a parte de ensino em si, mas como também iria ter uma certa criação e religião. De ter uma oportunidade melhor. Eu sempre estudei em colégio municipal (...) e ela teria uma oportunidade que eu não tive na época porque meus pais não tiveram condições de colocar as quatro filhas aqui. (...) Eu acho que os professores são mais comprometidos. O ensino em si é bem melhor. O primo dela estudou aqui na época que ela entrou e saiu. Quando ele foi para um colégio público, municipal, certas matérias ele já tinha dado aqui e voltou a estudar na escola pública. É essa a diferença". 
C. pondera que estudou em um bom colégio na época, apesar de ser uma escola municipal, e justifica dizendo que as pessoas que estudavam lá conseguiam entrar para o CAP (Colégio de Aplicação da Universidade Federal do Rio de Janeiro), e esclareceu: "esses colégios, só entrava se fosse aluno de colégio de município, tanto que tinha gente de todas as classes sociais. Na época, era um ensino bem melhor do que hoje em dia. Na minha época".

Contou-nos como usufrui suas horas de lazer, seu tempo de descanso:“Quando eu estou em casa vejo novelas. Quando eu consigo ficar acordada, esses programas que passam depois da novela como Fantástico, no domingo, e Jornal Nacional. Gosto de ir à praia quando faz sol".

Para ela, cultura significa bem mais do que frequentar a escola, e envolve até o conhecimento de literatura, teatro, etc.: "Ler bastante livros, revistas. Ter oportunidade de ir a teatro, cinema. Cultura é uma pessoa bem informada no caso, assim, não sei...” Pondera, entretanto, que está em dívida com a formação cultural da filha, porque "eu não leio muito, não tenho saído para teatro, cinema, essas coisas". Não considera que só a escola transmita cultura, mas a família também, porque "ajuda a complementar o que aprende na escola". Ela mesma aprendeu com os pais a respeitar as pessoas, procurar sempre dar bom dia, boa tarde. $\mathrm{Na}$ escola aprendeu "o saber, falar português, as matérias em si, porque, às vezes, muita coisa que eu estudei, matemática, por exemplo, não é usada no que eu faço hoje em dia (...), mas, assim, essas equações, essas coisas que a gente aprende..." 


\section{4 - Práticas e processos em ação no cotidiano escolar}

"Ter cultura serve; que serve, serve, só não sei para quê!!"

A escola, em que realizamos o presente estudo, trabalhou durante 70 anos com uma clientela de classe média e média alta, ou seja, tinha como corpo discente, alunos pertencentes à classe dominante que traziam em sua bagagem uma vivência e experiência na sociedade letrada, envolvidos em um mundo alfabetizado, educados em hábitos e atitudes para uma adequada convivência com seus valores. Sujeitos sociais com práticas socializadoras que permeavam suas relações, no entender da pesquisa de Thin (2006).

A opção feita pela Direção de fazer do colégio uma instituição voltada para o atendimento das camadas populares trouxe consigo um desafio pela diferença no perfil de aluno. Essa nova população de alunos vivia em um ambiente mergulhado na luta pela sobrevivência, com acesso precário à alfabetização inicial - marcado pela tradição oral - e à margem de um mundo centralizado em um sistema de representação alfabética da linguagem, com suas características específicas. Para definir camadas populares, recorreremos a Soares (1986), no intuito de situar o grupo de pertencimento dos habitantes das favelas cariocas. Segundo a autora, seriam os:

[...] grupos sociais que, pertencentes às classes dominadas, identificam-se por uma característica comum, a de constituírem um conjunto de grupos polarizados em oposição àqueles que detêm o monopólio do poder e do controle econômico e social (SOARES, 1986:80-81).

A maioria dos pais dos alunos veio do Norte e Nordeste e transmitem a cultura nordestina por meio de sua linguagem, seu modo e ritmo de falar. Os professores observam que, por trazerem uma outra cultura, geralmente a do seu lugar de nascimento (ou de seus pais), os alunos parecem apresentar certo mal estar ao falarem da região de onde vêm , como se essa cultura fosse vivida por eles como inferior: "acho que isso passa um pouco pela cabeça das crianças de ficarem até envergonhadas de, por exemplo, serem nordestinas", diz uma professora e acrescenta que a escola tem mais um papel, que é contribuir para desfazer esse preconceito, ressaltando e elevando o padrão cultural dos alunos, sem distinção e sem juízo de valor, para que estes possam lidar com os diferentes tipos de cultura e descobrirem o seu próprio valor, sem que a televisão seja o único instrumento transmissor de conhecimentos para eles. O objetivo, segundo esta professora, consistiria em fazê-los descobrir sua importância e, desse modo, sentirem-se com mais valia, apesar das condições precárias em que vivem na metrópole, para que possam se orgulhar do lugar de onde provêm e com direito 
à cidadania como qualquer outro, enfim, fazendo parte do amplo espectro constituído pelas culturas brasileiras.

Mas o que seria(m) a(s) cultura(s) brasileira(s)?

Bosi (2001), a propósito, já observa que "estamos acostumados a falar em cultura brasileira, assim, no singular, como se existisse uma unidade prévia que aglutinasse todas as manifestações materiais e espirituais do povo brasileiro". (BOSI, 2001:308). O autor comenta que a Antropologia Cultural já fazia uma distinção entre as culturas, segundo um critério racial: indígena, negra, mestiça e branca. Com o passar do tempo esses critérios foram mudados e superados, tal como consta na obra de Arthur Ramos (1943), Introdução à antropologia brasileira, passando a ter como distinção cultural o pertencimento a uma nação: européias (portuguesa, francesa, italiana, etc.) e não européias (culturas indígenas e negras).

Da categoria de raça passou para nação e de nação passou para classe social (cultura do rico, cultura do pobre, cultura burguesa, cultura operária), conforme ressalta Bosi (2001). Ele entende cultura como "uma herança de valores e objetos compartilhada por um grupo humano relativamente coeso" (BOSI, 2001:309), ressaltando a importância do plural nessas categorizações. Com base nesses critérios, ele introduz uma nova classificação, distinguindo a cultura erudita brasileira (centralizada no sistema educacional) da cultura popular (basicamente iletrada, cujos representantes seriam o homem rústico, sertanejo ou interiorano e o homem pobre suburbano, ainda não de todo influenciado pelas estruturas simbólicas da cidade moderna). Como consequência do alargamento da sociedade urbano-capitalista, Bosi acrescentou a essas duas faixas extremas e bem definidas, uma outra representada pelos artistas que não vivem nas universidades, mas que produzem uma cultura criadora individualizada, como escritores, compositores, artistas plásticos, dramaturgos, cineastas, enfim, intelectuais com um alto capital cultural. E ainda um quarto grupo cultural, que denominou de cultura de massas (cultura do consumo), um grupo que vive imbricado com os sistemas de produção e o mercado de bens de consumo, denominados de Indústria Cultural, conforme sustenta Adorno (1944; 1985), da Escola de Frankfurt.

Os estudantes da nossa pesquisa, pertencentes às classes populares, certamente estão inseridos em um grupo cultural, nesse sentido, e também são dotados de cultura.

Poderíamos caracterizar os habitantes das favelas, que marcam a vida urbana da cidade do Rio de Janeiro, como pertencentes às culturas variadas que constituem o universo 
do homem pobre suburbano (o que é bem diferente de dizer que têm uma cultura pobre), morador da cidade grande, que já assimilou parte das estruturas simbólicas da cidade moderna. Na sua maioria, são trabalhadores com pouca qualificação, que vendem sua força de trabalho para os grupos da classe dominante, em troca de um salário, muitas vezes, miserável. Habitam as conhecidas favelas dos morros do Rio de Janeiro, descritas por diversos autores, em prosa e verso, e cantadas em música . Segundo Zaluar e Alvito (1998):

\begin{abstract}
"área de habitações irregularmente construídas, sem arruamentos, sem plano urbano, sem esgotos, sem água, sem luz. Dessa precariedade urbana, resultado da pobreza de seus habitantes e do descaso do poder público, surgiram as imagens que fizeram da favela o lugar da carência, da falta, do vazio a ser preenchido pelos sentimentos humanitários, do perigo a ser erradicado pelas estratégias políticas que fizeram do favelado um bode expiatório dos problemas da cidade, o 'outro', distinto do morador civilizado da primeira metrópole que o Brasil teve. Lugar do lodo e da flor que nele nasce, lugar das mais belas vistas e do maior acúmulo de sujeira, lugar da finura e elegância de tantos sambistas, desde sempre, e da violência dos mais famosos bandidos que a cidade conheceu ultimamente, a favela sempre inspirou e continua a inspirar tanto o imaginário preconceituoso dos que dela querem se distinguir quanto os tantos poetas e escritores que cantaram suas várias formas de marcar a vida urbana no Rio de Janeiro" (ZALUAR \& ALVITO, 1998:7-8).
\end{abstract}

Ao considerarmos cultura como [...] conjunto de modos de ser, viver, pensar e falar de uma dada formação social; e, ao mesmo tempo, abandonar o conceito mais restrito, segundo o qual cultura é apenas o mundo da produção escrita provinda, de preferência, das instituições de ensino e pesquisa superiores (BOSI, 2001:319), cabe perguntarmos onde se articulam e se exprimem as culturas brasileiras? Em que lugares, tempos e modos fora da vida acadêmica? Para Bosi, diferentemente da Universidade, cujo universo é sistematizado e programado:

\footnotetext{
“o que caracteriza a cultura extra-universitária é precisamente o seu caráter difuso, mesclado intimamente com toda a vida psicológica e social do povo. (...) Os símbolos e os bens culturais não são objeto de análise detida ou de interpretação sistemática. Eles são vividos e pensados, esporadicamente, mas não tematizados em abstrato" (BOSI, 2001:320).
}

E, talvez, por isso mesmo, o povo se submeta, sem muita resistência ou reflexão, à indústria cultural que fabrica entretenimento em série baseado em algumas receitas de êxito rápido e/ou por meio de apelo à satisfação imediata via consumo, prendendo a atenção de milhões de consumidores culturais. Para Ortiz (2006), isso se deu com a transformação de uma sociedade que privilegiava o homem de produção e passou a ter como ídolos, pessoas de entretenimento, cujos maiores representantes são esportistas e artistas. Essa tendência difundiu um novo tipo ideal de comportamento a ser alcançado, o qual, segundo Ortiz, 
"estimula no leitor não mais uma tendência à realização de uma vontade, política e empresarial, mas o conformismo às normas da sociedade" (ORTIZ, 2006b:150).

Tomando em consideração tais ponderações de Ortiz e conhecedores das condições de vida dos alunos, objeto da presente pesquisa, retomamos a pergunta feita por Bosi (2001), que provoca o leitor a refletir: "Educar, sim, mas para qual cultura?" E acrescenta: "estamos educando e sendo educados em qual cultura?" (BOSI, 2001:342). O que Ortiz (2003) complementa, ao destacar que a etnografia pressupõe que haja uma relação ao mesmo tempo de distanciamento e de aproximação de uma dada cultura. Evidentemente que esse observador deve se encontrar "fora" do ambiente que lhe interessa e dele se aproximar para melhor observá-lo. Porém esse observador vem de uma determinada cultura, e nos perguntaríamos: a partir de qual olhar e qual perspectiva culturais o pesquisador analisará uma dada cultura para poder captar esse outro, esse modo diverso de vida e de pensamento?

No nosso estudo a observação da escola vem do trabalho de pesquisa de alguém do mundo alfabetizado, letrado e acadêmico. Tem como campo de observação uma determinada escola que se propôs a inserir mais de mil alunos das camadas populares na sociedade letrada. Sob qual perspectiva observamos e analisamos os fatos observados? Considerando essa realidade escolar e a opção que a escola fez por incluir a população da favela, até que ponto o projeto pedagógico implementado efetivamente conseguiu adaptar-se às novas condições? Qual imagem os professores fazem dos seus alunos? Quais expectativas a própria escola estabelece em relação ao trabalho em sala de aula? Seriam mantidos os métodos e os conteúdos da experiência anterior? Como isso se expressaria nos resultados escolares? Estas passaram a ser as questões principais da presente investigação.

Orientados por esses questionamentos, buscamos reunir os dados mais significativos para o desenvolvimento de nossa pesquisa.

Iniciamos as observações da parte acadêmica, com a fala da coordenadora pedagógica do colégio: "ainda não aprendemos tudo que eles têm a nos ensinar", que acrescentou ter se surpreendido com a grande influência do meio na vida desse povo, maior do que ela supunha. Exemplificou o que queria dizer, destacando que, na sua percepção, essa faixa da população atendida pelo colégio detinha, para além da cultura nordestina, outro modo de cultura, que ela denominou de cultura do medo, que é canalizada para uma cultura do enfrentamento, do revide, e que é sustentada pelo machismo. "É preciso bater! Tanto meninos como meninas. Se 
levar um beliscão tem que dar um soco". ${ }^{52}$ Ou, diríamos nós, que é própria à sobrevivência na metrópole, onde a presença do Estado como regulador das relações sociais é mínima.

Segundo a mesma coordenadora, haveria também a cultura da divisão de sexo: os alunos preferem fazer as atividades físicas com as meninas, de um lado, e os meninos, de outro. Os professores apoiam essa decisão e acreditam que os alunos 'funcionam' melhor separados, com menos problemas de comportamento e consequentemente as aulas decorrem mais tranquilas.

Além disso, a coordenação se deparou com uma cultura da fofoca, principalmente por parte das alunas, que falam muito mal umas das outras, e chegam a prejudicá-las. Uma hipótese apresentada é a convivência em um espaço exíguo, o que favorece saberem muito da vida alheia, decorrente da proximidade geográfica em que vivem, que faz desaparecer as linhas demarcatórias da vida pessoal e privada de cada família.

Outra coordenadora constatou uma cultura da comparação, notada quando fizeram uma pesquisa sobre o que a comunidade esperava do colégio. A maioria das respostas versou sobre a esperança de uma educação de qualidade para os filhos, igual à dada para a classe média, a mesma qualidade de professores e de passeios.

Nesse sentido, ela diz o seguinte:

"Dentro da própria comunidade do Vidigal, eles pensam que quem está aqui dentro, está melhor do que a vizinha dele que não está. Ele se sente classe média, o que exige, nesse processo educativo da escola, conscientizar o pensamento na construção desse bem comum. Essa escola, para que seja uma escola de qualidade, mas uma qualidade em que todos possam participar".

"Você vai vendo que muitas famílias que estão aqui, ainda não se deram conta de que aqui virou um centro mais popular. Em muitas cabeças isso aqui ainda é o Colégio Stella Maris de $1970 "$.

É preciso observar, entretanto, que o que a coordenadora chama de "cultura da comparação" pode estar relacionada muito mais com o direito que essa população identifica de ter um ensino de qualidade para seus filhos, que até então esteve destinado exclusivamente à classe média através do ensino privado. Quer dizer, o ensino público, embora tenha sido estendido para o conjunto da população, não significou um ganho de capital cultural e é isso que essa população espera obter quando uma ex-escola particular se abre para atender as

\footnotetext{
${ }^{52}$ Presenciei um trabalho em sala de aula quando houve um desentendimento em um subgrupo seguido por uma discussão. As meninas reagiram batendo nos meninos, chutando, mas não vi os meninos se comportando assim.
} 
classes populares e miseráveis que vivem em frente ao colégio nas favelas e que sempre foi relegada a segundo ou último planos, tanto pelo governo, como pelas classes dominantes.

Uma outra questão são os anseios de ascensão social que começam a ser despertados na população, quando apenas uma parcela passa a ser atendida por essa ex-escola dos ricos e de como isso passa a dividi-los, uma vez que se encontram totalmente identificados com o ideal de consumo das classes médias. No entanto, não se pode negligenciar que faz parte desse ideal de consumo, o desejo de inclusão nessa sociedade, que passa pelo poder de compra, inclusive de uma educação de qualidade. Segundo Ortiz (2006a), "uma ética de consumo não deriva apenas de necessidades econômicas. É preciso que ela se ajuste às relações determinadas pela sociedade envolvente e, simultaneamente, seja compartilhada pelos seus membros" (ORTIZ, 2006:119).

Ainda citando casos relativos ao que chamou de "cultura da comparação", a coordenadora relatou que as famílias que têm filhos com alguma dificuldade de aprendizagem são avisadas pela escola. Ela notou que há pais que aceitam bem. Entretanto se depara com pais que relutam e se negam a conhecer as dificuldades dos filhos. Indagou o seguinte a esse respeito: "Sabe por quê? O irmão dele ou o vizinho foi alfabetizado com 6 anos! As mães se preocupam com o que os outros dirão: "O que eu vou falar com a vizinha, que meu filho não deu conta?"

De outro lado, diante da ausência do Estado nessas comunidades, ou de sua presença ostensiva e ameaçadora, a escola seria o espaço por excelência de inserção, pela via da transmissão de uma cultura erudita, capaz de instrumentá-los a enfrentar, de um lado, uma realidade dominada pela cultura do crime, de outro, os apelos de consumo desenfreado. Nesse sentido, os professores buscam oferecer-lhes a riqueza das formas de cultura, das quais se encontram apartados, ao mesmo tempo em que procuram valorizar suas culturas de origem e, desse modo, os alunos possam adquirir a consciência de que existem outros modos de vida, de cultura e de conhecimento. Também orientada por esses objetivos, a Congregação faz com que as religiosas viajem e observem como outras pessoas vivem, pensam, enfim, conheçam diferentes usos e costumes, concepções de mundo, para que elas próprias vivenciem e trilhem o percurso que vão oferecer aos alunos.

Há uma professora nascida no Vidigal (mas que mudou de lá) que conversa muito com as crianças, mostrando que eles têm uma ótima oportunidade de fazer bons estudos e investir em uma carreira. Mas a coordenação constata uma desesperança nas camadas 
populares, observada nas conversas com os pais, visto que não acreditam que haja um futuro além dos serviços de moto-boy ou entregador de vídeo, que são as únicas profissões a que têm acesso. 


\subsection{1 - Cultura escolar e cultura popular}

“O grande desafio é nosso e não deles. Quais caminhos temos que percorrer?”.

(coordenadora)

Então vejamos. Até o momento concluímos que as famílias atendidas pela escola pesquisada habitam as comunidades do Vidigal e Chácara do Céu, compostas por pobres e cansados trabalhadores, moradores de favelas, que na sua maioria vieram do Norte e Nordeste. Tendem a negar suas raízes socioculturais e, até mesmo, sentem um certo mal-estar e, algumas vezes, vergonha, de suas origens (étnicas, sociais, culturais, geográficas). Tomam como padrões os modelos culturais das classes média e alta, e têm como parâmetro o modo de vida e de consumo dessas. Estão muito expostos à mídia como entretenimento e acuados pela cultura do crime e do medo, que desemboca em uma cultura da agressão e do enfrentamento, na qual impera a cultura machista e do falar mal da vida alheia, fazendo-os perder o foco de suas vidas.

Mas, então, qual seria o papel da escola diante desse cenário? Essa mesma escola que diz respeitar a cultura dos seus alunos, mas que vive o conflito de favorecer o ajustamento dos indivíduos às normas da sociedade estabelecida e atender à demanda do mercado?

François Dubet indaga se a escola é uma instituição e a define como uma instituição de socialização em um "sentido relativamente limitado de aparelho de socialização encarregado de transmitir uma cultura e de distribuir qualificações" (Dubet, 1996:170). Essa socialização escolar teria por função

[...] transformar valores em normas e papéis que, por seu turno, estruturam a personalidade dos indivíduos (...) A educação escolar distingue-se da educação que é dada na família pelo fato de ser, em princípio, 'voluntária'. Ela não tem em vista somente reproduzir uma cultura, ela é identificada com um modelo cultural que procura produzir um tipo de sociedade e de indivíduo. Deste ponto de vista, a escolha dos currícula compreende sempre uma parte de arbitrário e qualquer escola recorre a certas concepções de sujeito (DUBET, 1996:170 grifo do autor).

Na opinião de uma coordenadora

\footnotetext{
"o colégio procura fazer uma troca muito interessante com os alunos porque aproveita a experiência e a cultura deles. O Vidigal é formado por várias pessoas que vieram do Norte, Nordeste, então, é a cultura dessas regiões nas questões de alimentação, hábitos de vestuário... A escola tem mais que aproveitar a cultura deles e educar a partir disso".
}

No entanto, não tivemos a oportunidade de identificar algum nível de integração da cultura trazida pelos alunos em sala de aula. Em uma única aula, percebemos como os alunos 
ficaram atentos e a pertinência das perguntas e respostas dadas no momento em que uma professora expôs sobre o encanamento de água e o sistema de esgotos e demonstrou interesse por suas condições de vida, perguntando aos alunos como eram realizados esses serviços em suas casas e de como era feita a coleta de lixo. Foi um momento de grande participação dos alunos.

Segundo Bourdieu, a grade escolar reproduz de forma implícita as diferenças sociais no conjunto das disciplinas, consideradas de maior ou menor importância (pelo tempo dedicado a cada uma elas, por exemplo):

\begin{abstract}
"A exemplo das distinções entre os sexos e as faixas etárias, são também diferenças sociais que recobrem as diferenças entre as disciplinas ordenadas segundo uma hierarquia comumente reconhecida: desde as disciplinas mais canônicas, como o francês, as letras clássicas, a matemática ou a física, socialmente designadas como as mais importantes e mais nobres (dentre outros indícios, em virtude do peso nos exames, pelo estatuto de 'professor principal' conferido aos docentes dessas áreas e, finalmente, pelo consenso dos docentes e dos alunos), até as disciplinas secundárias como a história e a geografia, as línguas vivas (que constituem um caso à parte), as ciências naturais, e as disciplinas marginais, como o desenho, a música e a educação física" (BOURDIEU, 1974:238)
\end{abstract}

Ao analisarmos a grade curricular das $5^{\mathrm{a}}$ e $6^{\mathrm{a}}$ séries, constatamos o peso das disciplinas "canônicas": Português (6 horas/aula) e Matemática (5 horas/aula); seguida pelas disciplinas "secundárias" todas com 2 horas/aulas: Ciências, História, Geografia, Inglês, Educação Física e Educação Religiosa e, finalmente, as disciplinas "marginais", mais desvalorizadas: Educação Artística e Educação Ambiental com 1 aula quinzenal ${ }^{53}$. Note-se que, apesar de sustentarem que se preocupam com as culturas dos alunos, não há nada que indique estudos específicos, por exemplo, acerca da cultura afro-indígena, ou mesmo sobre as especificidades da cultura nordestina, da tradição oral dessas culturas, da especificidade de sua linguagem, ou mesmo das hibridações entre a cultura oral e a cultura erudita que atravessam a cultura oral nordestina.

A disposição da grade curricular das $5^{\mathrm{a}}$ e $6^{\mathrm{a}}$ séries do $2^{\mathrm{o}}$ segmento do Ensino Fundamental indica a concepção de cultura que é oferecida aos alunos, ressaltando a expectativa pressuposta para a sua formação, que se encontra permeada pelos modelos de cultura e de conhecimento que antes eram oferecidos à elite que frequentava a escola à época da implantação do projeto, e que depois passaram a ser oferecidos às camadas populares. $\mathrm{O}$

\footnotetext{
${ }^{53}$ São substituídas na $7^{\text {a }}$ série por aulas de Desenho geométrico, Álgebra e Geometria, dentro da disciplina Matemática.
} 
projeto aponta incoerências e conflitos entre a distribuição do tempo e disciplinas, apesar de constatarem que:

\begin{abstract}
"A cultura musical desses alunos é mais ligada ao forró, pelo fato de a maioria ser nordestina, mas é acrescida do ritmo funk, porque é da comunidade onde têm os bailes funks. A escola está trazendo a música popular brasileira para oferecer outros horizontes. A escola deve trazer o que eles talvez não conheçam ou, então, que eles já conhecem, mas vai ser enriquecido. E eles trazem a sua cultura que não pode anular e muito menos achar que a nossa cultura é melhor do que a deles. Teremos essa flexibilidade, essa sabedoria, essa sensibilidade, é a palavra certa, de sentir o seguinte: está bom, a cultura deles é essa, mas a gente pode chegar e num determinado momento mostrar a eles que existem outras coisas e ampliar esse mundo deles. A mesma coisa é o forró. Forró é da comunidade também, muitos nordestinos, eles adoram a feira de São Cristóvão".
\end{abstract}

Uma coordenadora relatou que as crianças gostam da música da Bia Bedran, mas que se ela deixar a escolha das músicas por conta dos alunos, invariavelmente "é um funk só. Tem uns funks que você não pode ficar repetindo na sala porque têm um linguajar muito vulgar. São essas músicas que eles ouvem em casa”. Então as professoras foram incentivadas a apresentar propostas diferentes e mais 'significativas' e conversar com eles também.

O trabalho de Herschmann (2000) sobre o funk mostra que há um preconceito contra esse tipo de música, uma vez que é analisada segundo os padrões morais da classe média e não do povo, cuja moralidade se vê ampliada e revista de acordo com os costumes e moralidade comuns às próprias raízes afro-americanas da cultura que gerou o estilo funk. "Pode-se afirmar que o funk, na medida em que alcançou destaque inusitado no cenário midiático, foi imediatamente identificado como uma atividade criminosa, uma atividade de gangue, que teve nos arrastões e na 'biografia suspeita' dos seus integrantes a 'contraprova' que confirmaria este tipo de acusação" (HERSCHMANN, 2000:51). Como a maioria dos adeptos dessa música são personagens oriundos das áreas carentes da cidade - espaços cuja representação social é de que se tratam de lugares em que as pessoas estão vinculadas à criminalidade e à violência urbana - uma visão preconceituosa dos espaços da violência urbana, diga-se de passagem, bastante veiculada pela mídia - acabou-se associando os que gostam de funk com o crime. Além disso, ressalta Herschmann, é preciso diferenciar a música funk da música pesada que tem um linguajar vulgar e que acaba por banalizá-lo.

E a coordenadora continuou contando a surpresa que teve ao constatar a criatividade das crianças por ocasião da apresentação de uma dança e/ou de uma atividade de teatro:

\footnotetext{
"Parecia que elas tinham uma coisa de artista no sangue, pode ser uma criança super tímida, que se colocar uma música ela dança e consegue atuar no teatro. Existe um grupo - Nós do Morro - dirigido por uma pessoa da TV Globo, com crianças que aparecem nas novelas, nos comerciais. Pois não é que as famílias da comunidade se preocupam em fazer o 'book' de suas
} 
crianças para encaminhar para esse grupo encontrar trabalho para elas! As perspectivas das

famílias são outras...”

E ressaltou sua discordância diante dessa atitude, por considerar que contribuía para a valorização do corpo da criança acrescentada da construção de uma imagem pré-fabricada da favela e de seus moradores. Evidencia-se aqui um discurso que versa sobre a espontaneidade artística da criança acostumada a experienciar em seu meio uma cultura de rua, com todas as manifestações que lhes são próprias - em que se combinam as artes da dança, da música e do teatro - com a cooptação para outros fins da Rede Globo, que perversamente seleciona-os para trabalhar, coniventes com essa imagem.

A professora considera que é sua função ampliar "sem matar a cultura do outro, não negar, não ter preconceito com a cultura do outro, mas sim ter a sensibilidade para trabalhar e poder dizer: Olha você tem essa e eu tenho essa, vamos juntar? Para crescer e enriquecer".

No entanto, nossas observações apontam a existência de diferenças tanto nos hábitos de alimentação e vestuário como de estilo de música e dança, mas que não são explicitados. Os alunos apreciam músicas ligadas ao estilo e ritmo do forró, muitas vezes, acrescido da música funk, em que prevalece um linguajar extremamente coloquial, considerados preconceituosamente como vulgar, mas que são escutados por todos em suas casas. A escola oferece, a título de ampliação do universo cultural desses alunos, a música popular brasileira. Segundo os professores, é "para oferecer outros horizontes". Mas aqui ficamos com a indagação: o forró e o funk não são brasileiros? Além disso, perguntamo-nos de que modo se passa essa valorização com aulas quinzenais de Educação Artística.

\subsection{2 - Cultura na visão da comunidade}

Nos estudos de caso realizados a propósito dos quatro alunos, mencionados anteriormente, indagamos aos seus pais, professores, coordenadores e diretores, o que pensavam sobre cultura para conhecermos suas versões, perspectivas e pensamentos acerca do tema.

Organizamos o vasto material que nos foi apresentado e começamos re-apresentando o ponto de vista da mãe de Miriam, uma senhora que pediu que não gravasse a entrevista por achar "um pouco vergonhoso", porque seu estudo foi até a quarta série. Para ela "ter cultura serve, que serve, serve só não sei para quê!’” 
Essa questão será o eixo condutor da discussão do material pesquisado, a partir do qual problematizaremos a noção de cultura da comunidade.

Começamos pelos entrevistados que confundem cultura com escolarização. A maioria dos pais tem uma noção de cultura associada à ideia de que ter cultura (escolaridade) é condição para ascender socialmente em prol de um futuro melhor. Outros, além desse aspecto, defendem a ideia de que seja um valor moral com parâmetros claros de certo e errado, a partir do qual determinam-se regras coerentes com esses princípios, que deverão nortear as condutas de cada um.

Para a mãe de Miriam, que pôde estudar somente até a $4^{\mathrm{a}}$ série do Ensino fundamental, cultura é definida como uma mistura de cursos, expressões artísticas e festas populares e conduta segundo certos preceitos morais: "É participando das aulas que tem na escola, fazendo inglês, frevo e festa junina. São modos de ser. É respeitar as pessoas, nunca pegar nada de ninguém."

Para a mãe de Nara, que sempre estudou em colégio municipal e tem o segundo grau completo, cultura significa ter acesso aos diversos veículos da cultura erudita, além de noções de civilidade: "Ler bastante livros, revistas. Ter oportunidade de ir a teatro, cinema. Cultura é uma pessoa bem informada. É respeitar as pessoas, procurar sempre dar bom dia, boa tarde”.

Para a mãe de Homero, com o primeiro grau na escola pública e que aos 32 anos voltou a frequentar a escola para fazer o ensino médio, cultura são modos de ser e de viver, muito próxima da ideia de usos e costumes: “Como alguma coisa, mas que não sei explicar. É muito o que a gente vive, o dia a dia. Meu marido transmite cultura porque entende de muita coisa, lê muito. Ele é estruturado. Eu passo cultura na organização da minha casa. Na minha maneira de viver no mundo. Com certeza comportamento, como lidar com as pessoas, respeito ”.

A opinião das mães aponta para a realidade com que veem a vida, e a esperança que têm em relação ao futuro dos filhos. Uma delas fala com dissabor sobre sua condição: “morar em favela e ainda em casa alugada! Ninguém merece!”. Desvaloriza seu trabalho de manicure ao contrapor sua profissão às profissões às quais a filha poderá ter acesso se estudar; 
"Eu falo para minhas filhas, claro que você vai me obedecer, você é pequena e vai me obedecer, mas você tem que estudar focando em você. Naquilo que você quer ser. Você não vai querer ser que nem eu. Você vai querer ser manicure? Cabeleireira? Não quero isso para elas. Quero que elas tenham o que eu não tive".

Duas delas percebem a família como transmissora de cultura no sentido de adquirir "boas maneiras", quando diz:

\begin{abstract}
"Eu procuro ensinar minhas filhas do jeito que eu fui criada. Procuro ensinar coisas do bem. Não praticar o mal nunca. Não sou de falar palavrões porque eu não gosto. Porque se eu for falar minhas filhas também vão fazer a mesma coisa. Eu lembro que eu aprendi muito do meu avô. Ele sempre falava: minha filha respeite para você poder ser respeitada. Você tem que ter respeito. Porque se você não se impor, não se valorizar, quem é que vai valorizar? Ninguém”.

"Quando estou em casa, a organização da minha casa, a minha maneira de viver no mundo, isso tudo é cultura que estou transmitindo para meus filhos, que está difícil de entrar na cabeça deles (em tom de desabafo) 'é muito complicado a gente tentar passar as coisas. Eles não querem entender. Acham que a gente é velho, que está ultrapassado'. Meus pais me ensinaram educação, com certeza comportamento, como lidar com as pessoas, respeito. Eu acho que isso é muito importante na nossa vida. Porque respeitando o próximo, se todos respeitassem o mundo seria muito melhor, não é?"
\end{abstract}

Neste último depoimento, ficam claras as dificuldades de educar os filhos e se fazer respeitar por eles, em um mundo marcado pelo culto à juventude e à informação imediata a que se tem acesso pela internet, o que tem desautorizado as antigas gerações em relação às novas gerações, que "supostamente" sabem mais que seus pais. Tudo isso, associado ao baixo nível de escolarização dos pais e à desvalorização de suas experiências e cultura de origem, tem feito com que estes se sintam sem condições de transmitir cultura a seus filhos, atribuindo o lugar de transmissores de cultura à escola ou a alguém com maior nível de escolarização na família, embora alguns tenham uma leve suspeita de que cultura seja algo que vai além da cultura escolar:

"Ele [o marido] é muito mais específico para essas coisas e apesar das crianças acharem que ele é chato, ele está certo e ele conversa muito com as crianças”.

"Me explique o que é cultura que depois eu continuo. São modos de ser. Em Pernambuco as pessoas são mais amigas, aqui não sabe quem é seu amigo, quem não é. Em Pernambuco é melhor, mas não tem trabalho. Se tivesse aonde trabalhar... Saí de lá para escolher uma coisa melhor. Tentar né!”

"Eu não! (transmito cultura) porque eu não leio muito, não tenho saído para teatro, cinema, essas coisas (...), mas a família ajuda a completar o que aprender na escola porque eu aprendi com os pais a respeitar as pessoas, procurar sempre dar bom-dia, boa-tarde".

"Acho que na verdade não tenho cultura principalmente onde eu fui criada que é uma cidade pequena. E a capital é mesmo Fortaleza e eu nunca nem fui a Fortaleza”.

Essas quatro mães entrevistadas apresentam uma noção de cultura ligada às boas maneiras e à civilidade, transmitidas de uma geração à outra, por pais e mães comprometidos, 
no exercício de sua função parental, servindo de exemplo para os filhos, no respeito mútuo da convivência diária. Demonstram, entretanto, algumas contradições em seus discursos, quando não parecem acreditar na riqueza de suas palavras e tampouco se veem como transmissoras de cultura. Atribuímos essa contradição vivida por essas mães ao fato de trazerem a ideia de cultura como informações adquiridas formalmente, desconhecendo outras concepções como as sustentadas pela educadora Magda Soares (1986), quando se refere às ideias do antropólogo Geertz (1989). Para ele, cultura é um "padrão historicamente transmitido de significados encarnados em símbolos, um sistema de concepções herdadas, expressas em forma simbólica por meio dos quais os homens comunicam, perpetuam e desenvolvem seu conhecimento e atitudes em relação à vida" (GEERTZ, 1989:66).

Para Soares (1986):

[...] Não há grupo social a que possa faltar cultura, já que este termo, em seu sentido antropológico, significa precisamente a maneira pela qual um grupo social se identifica como grupo, através de comportamentos, valores, costumes, tradições, comuns e partilhados. Negar a existência de cultura em determinado grupo é negar a existência do próprio grupo (Soares, 1986:14).

\subsection{3 - Cultura na visão dos professores e coordenadores}

Do ponto de vista dos professores e coordenadores, que pensam de um modo semelhante ao dos pais acima referidos, cultura envolve formação intelectual e modos e maneiras de ser na vida:

\footnotetext{
"Cultura é tudo aquilo que as pessoas recebem para que possam perceber a história de um povo. Como que esse povo foi se enriquecendo e a possibilidade que tem de continuar a crescer. $O$ que se recebe como cultura faz com que o povo se posicione mais na vida, entenda mais o que está acontecendo no país, senão fica estagnado”, diz uma coordenadora.

Para uma professora de Matemática:

"Cultura tem que ver com conhecimento de uma maneira ampla, sobre todos os assuntos, inclusive os que estão na sua volta, os que estão na sua vida, que fazem parte desse mundo. Que o aluno não só soubesse que o Lula é o presidente do Brasil, mas também que ele soubesse sobre o Barack Obama, que talvez seja o primeiro presidente negro dos Estados Unidos e que tem essa oportunidade. Que o aluno tivesse o conhecimento mais abrangente dos assuntos, que ele tivesse informação sobre o mundo em termos de futuro, que ele tivesse informação para poder fazer suas escolhas, e com um leque aberto à sua frente. A cultura talvez fosse esse leque", conclui a professora.
}

A cultura é a lente através da qual o homem vê o mundo, diz Benedict (1972). 
Para a professora de Inglês: "Cultura é você conhecer um pouco de tudo, com prazer em conhecer, em descobrir e não ficar esperando que as coisas aconteçam”.

Do ponto de vista de dois antigos professores de Educação Física, para se adquirir cultura:

"É preciso acesso a teatro, a todas as possibilidades, a museus, conhecer por que fulano fez, assim, o que o levou a fazer. Cultura é um conjunto de conhecimentos. São as coisas que você vai vivendo e construindo através dos tempos. $O$ que os povos vão construindo, seu modo de falar, de viver, de se comunicar, suas brincadeiras, seu estudar. Enfim, como constrói e vive nessa sociedade. Cultura é mutante e vai agregando. O tempo faz com que as coisas mudem porque antigamente cultura era saber o nome de todas as capitais e hoje em dia isso não tem mais importância. A educação mudou porque ela muda em função da sociedade, mas a educação está atrasada pelo fato de não evoluir tanto quanto outras áreas da sociedade”.

Para outra professora de Artes, cultura é singular porque cada um tem uma cultura:

"Porque eu fui criada de um jeito, num lugar, então cultura é justamente isso. O que a pessoa adquire na sua vida, no seu meio ambiente. Seria conhecimento”.

"Para lidar com a comunidade tem que trabalhar com a cultura que eles trazem e acrescentar também a nossa como pessoa, a nossa bagagem, o professor, a própria escola, a própria experiência da gente, a cultura aí fora e ao mesmo tempo integrando a cultura que eles trazem”.

Como vimos, a educação não é mais privilégio das classes abastadas, decorrendo daí trocas culturais e influências mútuas como resultado da variedade de culturas existentes e dos contatos entre elas. Segundo Romanelli $(1978 ; 1983)$ "essas trocas, quando se processam, tendem a fazer enriquecer as culturas interessadas, já que as diferenças notáveis entre elas são outros tantos desafios à imaginação e à inteligência humanas" (ROMANELLI, 1983: 20). A cultura é enraizada no homem, no tempo e no meio em função dessas circunstâncias criadoras, uma vez que está ligada a uma situação concreta e objetiva: ela se faz num tempo e num espaço determinados e é através dela que os homens vão assimilar o mundo próprio do homem, isto é o próprio modo de ser humano.

Ora, a cultura veiculada pela escola é eminentemente erudita, e como tal tem sido valorizada através dos tempos. Já os alunos do Centro Cultural Stella Maris a partir do ano 2000 trazem uma cultura de tradição ${ }^{54}$ oral, grosso modo desvalorizada desde os tempos da colonização. Ora, caso as trocas e influências culturais se dêem dentro de circunstâncias favoráveis,observar-se-á um mútuo enriquecimento, no entanto, corre-se o grave risco de resultar no aniquilamento de uma delas, se for priorizada uma em detrimento da outra.

\footnotetext{
${ }^{54}$ Defino tradição conforme Ortiz: "é aquilo que carregamos conosco, que se impõe como carga e também como identidade" (Ortiz, 2006b)
} 
Consideramos que as entrevistas com o corpo docente dessa instituição assinalam o desafio assumido por ele de vir a conhecer e valorizar cada vez mais a cultura trazida pelos alunos, evitando que se realize apenas uma espécie de transferência pura e simples dos padrões e modelos da cultura erudita.

A teoria social de Bourdieu destaca a ascendência do papel da escola - representada, sobretudo pelo corpo docente que tem o saber como capital simbólico - junto às camadas populares, pelo fato de a primeira permitir a estas o acesso à titulação, a um nível de conhecimento geral e de boas maneiras, atributos estes que lhe dão uma posição de destaque e de poder.

Para Arendt (1979) a criança normalmente é introduzida ao mundo pela primeira vez através da escola, e nesse sentido a escola representa o mundo: "nesse caso o educador está aqui como representante de um mundo pelo qual deve assumir a responsabilidade, embora não o tenha feito e ainda que secreta ou abertamente possa querer que ele fosse diferente do que ê" (ARENDT, 1979: 239). É informar e transmitir a seus alunos as conquistas a que o ser humano chegou a fim de que compreendam melhor determinadas questões do mundo à sua volta. "A função da escola é ensinar às crianças como o mundo é, e não instruí-las na arte de viver"(ARENDT, 1979: 246).

Esses garotos e garotas estão nascendo para o mundo; suas famílias demonstram baixa estima pelo pouco capital que possuem, não só o econômico mas também o escolar, o social e o cultural. Poucas chances eles (pais) tiveram para modificar essa situação, e a escola, de modo geral, tem uma relação estreita com essa baixa auto-estima. A posição social, o capital escolar e a origem social distinguem as pessoas e sua aquisição torna o povo mais apto e preparado para tomar consciência e poder fazer transformações na política, tomar decisões, pequenas ou grandes, que o favoreçam.

\subsection{4 - Escola: expectativa dos pais da comunidade}

\footnotetext{
"As professoras percebiam certa desconfiança dos pais em relação ao colégio: 'Por que o Stella Maris fez isso? Será que chamaram a gente por que não tinham aluno? Será que vão trabalhar com seriedade?'Foram três anos de explicação para ganhar a confiança deles e até hoje explicam o trabalho minuciosamente e, com isso, mostram o maior respeito do mundo por eles" (Depoimento de uma coordenadora).
}

Os professores são unânimes na observação de um grande respeito dos pais e familiares em relação ao trabalho que realizam. Passados os primeiros constrangimentos 
oriundos de uma grande desconfiança em relação à opção feita pela escola, os pais hoje reconhecem a dedicação que têm com seus filhos e demonstram grande expectativa quanto ao bom aproveitamento escolar de seus filhos nesta escola.

O corpo docente percebe o compromisso assumido pelos pais em relação à educação dos filhos. Ao inscreverem seus filhos na escola são informados sobre as mensalidades, sobre a necessidade de contribuir de alguma forma, e sobre o direito à bolsa escolar. Eles se sacrificam para pagar a mensalidade escolar, pois têm inúmeras dificuldades para enfrentar a realidade da vida, como emprego e pouco dinheiro. Além do pagamento da cota ainda têm que comprar o material escolar. Em geral, nos momentos difíceis, os pais procuram a escola para renegociar a bolsa.

A realidade dura da vida é um dos pontos de pressão para os alunos que sentem e sabem da expectativa dos pais em relação aos seus estudos, ao mesmo tempo em que têm plena consciência de não poderem contar com eles para a realização das tarefas e deveres escolares:

\footnotetext{
"Quando preciso de ajuda peço para minha tia, que é irmã da minha mãe e que mora perto da minha casa. Não peço para a mãe porque ela não estudou muito, talvez até a $6^{a}$ série, e o pai não tem tempo porque ele trabalha muito".

"Se tenho dúvida no dever espero até o dia seguinte para perguntar para o professor porque meus pais não estudaram, não tiveram oportunidade".
}

A "oportunidade" de estudar em uma escola cujo ensino fora dedicado às classes abastadas é mais um motivo de pressão, porque eles ouvem permanentemente esse discurso, no âmbito escolar, sobretudo, da chance que estão tendo por estudar nessa escola. No entanto não se pode esperar que os alunos tenham o amadurecimento necessário (por falta de idade e de experiência na vida) para darem sentido e significado para esse discurso feito tanto pelos pais em casa como pelos professores em sala de aula. A pouca experiência de vida não lhes permite compreender e medir a extensão do que se espera deles, embora sintam a pressão pelo reconhecimento, talvez sem saber decodificá-la. Parecem acreditar que estão recebendo nada mais do que a obrigação - ensino em uma escola física e academicamente preparada para ser escola. Ou seja, reagem como crianças que esperam ser cuidadas do melhor modo possível, no entanto, diante de um Estado omisso, ou mesmo ineficaz, e de uma escola religiosa que entende ter feito essa opção por compaixão, parecem não corresponder do mesmo modo que seus pais, que são imensamente gratos. 
Para a coordenadora os pais veem o estudo nessa escola como muito vantajoso e esperam um retorno dos filhos. Em relação à comunidade, percebeu que os pais têm procurado muito a escola para desabafar. Ela relatou: "vem falar da criança e junto com a fala sobre a criança você vai vendo que está a história da pessoa também, o que a família está vivendo no momento. Tem mães que seguram muito os filhos: tem muita criança que não cresce porque a mãe não deixa”. Ela atribui ao fato de muitas delas já terem vivido esse problema em casa com os irmãos e temerem que o filho "vire bandido' e passe a viver na ilegalidade. Mais uma vez, a escola é uma opção para escapar desse cruel destino, daí a alta expectativa dos pais com relação à competência da criança:

\footnotetext{
"As famílias fazem muita pressão - o aluno tem que ser o melhor. Às vezes a criança não pode errar; muitas vezes a criança não vai para frente porque ela não pode errar. Ela escutou a mãe falando que ela tem que fazer tudo certo, mas ele não consegue aprender. Não se permite errar".
}

Nas primeiras reuniões com os pais, segundo a coordenadora observou, a fala de muitos pais foi recorrente quando diziam:

\begin{abstract}
"Eu tive dificuldades. Eu não fui para frente porque eu não tive a oportunidade que meu filho está tendo aqui. Eu fico muito feliz de saber que hoje vocês trabalham isso. Eu não tive essa oportunidade principalmente na fase da leitura e da escrita". E ela finalizou: "Muitos ficaram analfabetos".
\end{abstract}

Dubet nos auxilia ao trazer à tona a armadilha presente nessa discussão, que fica difícil de romper, pois existem duas concepções da função da escola em jogo. De um lado, os professores com uma concepção de escola, como lugar de educação e instrução, buscando e privilegiando desempenhos e competências específicas dos seus alunos, com a afirmação das regras e das hierarquias escolares e, em contrapartida, as famílias, representadas pelos pais, querendo que a escola seja centrada na criança e no adolescente, e "sonham com uma escola que não seja unicamente escolar e que dê aos alunos o que a família e a sociedade já não lhes pode oferecer" (DUBET, 1996:176)

Constatamos, como bem observou Freller (2001), que o estudo é valorizado e percebido pelos alunos e pais como fator de melhoria de vida. Os alunos entrevistados dizem não faltar à escola porque gostam de ir e seus pais não deixam faltar por considerarem o ensino como a coisa mais importante em uma escola. Segundo Miriam, por exemplo, "se estudasse seria esperta”.

A mãe de Diva diz o que ela espera de uma escola: 
"Puxa! De uma escola? Eu espero que as minhas filhas aprendam. Venham a aprender, venham a ser alguém na vida. Ter o estudo que eu não tive. Acho importante estudar porque hoje em dia está tudo muito avançado. A tecnologia está muito avançada. Você com estudo já está ruim. Você vê muita gente que tem estudo, mas não tem emprego. Eu mesmo não tenho estudo. Tive que procurar uma profissão para eu fazer. Seja qual for. Se você não tiver um estudo tem que ter uma profissão. Eu cobro muito delas. Eu falo para elas o contrário do que eu fui no colégio. Para elas não brigarem e procurar sempre estar com boas amizades no colégio. Eu falo: minha filha, colégio a gente vai para estudar e não para brincar porque para isso tem a hora do recreio. Essa escola aqui para mim foi uma bênção. Só o fato de eu ter minhas filhas aqui. De estudar perto de casa, de eu não ter o trabalho de levar para a escola".

Do mesmo modo, a mãe de Homero tem grande expectativa em relação à escola e comentou:

"De uma escola eu espero tudo para o meu filho. O futuro do meu filho está garantido numa escola. Apesar de ele querer ser jogador de futebol, diz que quer estudar em outra escola para ter tempo de treinar, dai eu falei para ele: Não. Enquanto você não terminar, de lá você não sai. Isso aqui foi uma oportunidade para a gente que não tem nem como agradecer. Eu acho que o estudo abre portas para tudo".

A aluna Miriam conta que sempre gostou de estudar e seus pais gostam que ela estude. Ela entrega seu boletim e os avisos de reuniões à mãe, que vai às reuniões. Seu pai também conhece sua escola porque "vai comprar livro", mas nunca foi a uma reunião. É sua mãe quem acompanha seus estudos, sempre perguntando sobre a escola; algumas vezes seu pai também pergunta, mas é a mãe que "reclama" se ela não estuda. Miriam acredita que com estudo conseguiria ter um bom emprego.

Sua mãe espera que, na escola, sua filha:

"aprenda, se desenvolva, trate as pessoas bem. Uma escola já diz tudo, já é para aprender, vir para estudar mesmo. Quero para M. um futuro bom, para a minha filha. Que estude, aprenda para fazer uma faculdade, vou fazer de tudo para ela conseguir fazer uma faculdade".

A mãe de Nara tem clareza sobre o motivo da escolha dessa escola e valoriza o amplo

benefício de um bom ambiente escolar:

"Pelo fato do ensino ser bem melhor do que as escolas que têm aqui próximas. Aqui ela aprenderia muito mais de um jeito, é, por causa das irmãs seria um ensino mais assim, como vou explicar, pelo fato da doutrina religiosa, dos ensinamentos, não só em aprender a parte de ensino em si, mas como também iria ter uma certa criação e religião. De ter uma oportunidade melhor. Eu sempre estudei em colégio municipal (...) e Nara teria uma oportunidade que eu não tive na época porque meus pais não tiveram condições de colocar as quatro filhas aqui. (...) Eu acho que os professores são mais comprometidos. $O$ ensino em si é bem melhor. O primo dela estudou aqui na época que ela entrou e saiu. Quando ele foi para um colégio público, municipal, certas matérias ele já tinha dado aqui e voltou a estudar na escola pública. É essa a diferença”. 
Os pais registram a utilidade dos estudos e lembram-se de que as qualificações escolares são bastante úteis aos que as adquirem, pois os diplomas são mais ou menos bem pagos no mercado de trabalho.

Para a realização dessa investigação, encontramos uma grande contribuição na experiência de intervenção na rede pública de ensino coordenada por Amaral (2007b), que, ao se referir às expectativas dos alunos quanto ao papel da escola em suas vidas, afirma o seguinte: "Em todo caso, todos são unânimes em dizer que o estudo é fundamental para que tenham um lugar de respeito na sociedade, uma idéia que é traduzida por uma frase reproduzida repetidamente pelos alunos (e, acrescentamos, por seus pais também) (AMARAL, 2007b: 240):

- "Ser alguém na vida!".

Apesar de tantos elogios proferidos em relação a essa escola, observamos que nas entrelinhas das entrevistas com as mães, essas mostraram certo ressentimento, pois três mães comentaram as ocasiões em que a escola não as convidou a participar de algum evento, e falaram espontaneamente sobre esse assunto:

A mãe da Miriam disse que nunca vai à escola porque a filha passou a vir sozinha da $5^{\mathrm{a}}$ série em diante. Fez questão de dizer que moram pertinho da escola. Mas se a convidam para as festas ela vem, mas fala: "Não é sempre que convidam".

A mãe de Homero contou que seu contato com a escola é mais através das reuniões, e diz: " $E$ muito difícil eu faltar numa reunião. Só se eu tiver algum problema. Vou às festas da escola quando os pais são convidados".

A mãe de Nara disse que acompanha a vida escolar da filha, sempre indo às reuniões do colégio e às festas: "quando é liberado, as festas, eu procuro vir".

\subsection{5 - A visão da comunidade do ponto de vista dos professores e coordenadores}

$\mathrm{Na}$ entrevista com a diretora, ela esclareceu o início do projeto e relatou que em várias reuniões da congregação entrou em pauta a questão do Colégio Stella Maris, situado ao pé do morro, junto às favelas do Vidigal e da Chácara do Céu, com população bastante empobrecida e já atendida pelo colégio através de cursos, mas nunca como um projeto estruturado de ensino. Muitas bolsas eram dadas a funcionários e professores. Passaram a acreditar que poderiam dar sua contribuição e melhorar um pouco a vida dessa população tão marginalizada e concluíram que deveriam fazer essa experiência. Foi assim que o processo começou. 
O projeto foi crescendo e se desenvolvendo, e segundo as palavras da Irmã ,"hoje indo de vento em popa", e observa que a Congregação olha com muito afeto o projeto do Stella Maris. Mas declarou que não foi fácil, pois logo no início as religiosas tiveram muitos problemas e sofreram muito com a invasão de traficantes na favela do Vidigal. Ela, quando chegou para assumir a direção da escola, encontrou a situação melhorada, mas mesmo assim chegou a escutar tiros, em algumas ocasiões. Antes dessa trégua, todas viviam sob constante tensão, hoje atravessam um tempo de paz, mas adverte: "Paz entre aspas porque continua esse tráfico, mas está muito mais calmo. As crianças têm tranquilidade".

A superiora avalia que essa instituição de ensino atende a expectativa dos habitantes da favela e que eles realmente se sentem felizes; no seu julgamento, por dividir o espaço com eles, constata o respeito que demonstram com a congregação, pois o colégio nunca foi ameaçado em todas as invasões [refere-se às guerras de traficantes de drogas que disputam o domínio dos pontos de venda de droga nas favelas]: "Enquanto outras escolas fechavam por causa do tiroteio nós continuamos a funcionar sem ameaças. Há esse respeito por parte da comunidade". 55

Os integrantes no Conselho de Classe também relataram que consideram o trabalho nessa escola bastante árduo, pois além da questão da violência do tráfico de drogas da favela, elas notam seus alunos carentes de amor "porque muita criança fica em casa sozinha ou com uma cuidadora enquanto a mãe e o pai saem para trabalhar, vivendo uma infância triste por conviverem desde cedo com a violência e apanhando muito em casa".

Uma das coordenadoras comentou que elas constataram que se a escola reclamasse do comportamento dos filhos com os pais, eles resolviam a questão na base do tapa, da agressão física: "Isso nós custamos a entender, que não adiantava a gente falar o que os meninos estavam fazendo aqui e que a escola precisava de ajuda, porque eles chegavam em casa e batiam nos filhos".

A pesquisa de Thin constata que "os pais das famílias populares comumente usam castigos corporais para punir os atos repreensíveis" (THIN, 2006:217).

\footnotetext{
${ }^{55}$ Numa aula dada na horta subitamente ouvimos uns estampidos fortes e estranhos. Imediatamente ficamos todos atentos e os alunos começaram a falar sobre tiroteios ocorridos na favela, como se estivessem permanentemente em estado de alerta. Com o cessar do barulho, aos poucos todos controlamos a situação e a aula pôde continuar.
} 
Só em alguns casos elas avisam certas atitudes dos alunos, mas enfatizam: "a fala da escola tem que ser a fala da família, desde que eles, pais, estão com os filhos aqui nessa escola é porque acreditam na educação dada, então é preciso que todos falem a mesma linguagem".

Mas inúmeras vezes o retorno dos pais é: "mas vocês vão dar conta deles", e colocam esse papel para a escola, "um papel que não é só a escola que deve dar".

Para a superiora, a escola é permeada pela pobreza em todos os sentidos: " $O$ aluno vive numa casa pequenininha, a mãe tem que trabalhar muito, não tem dinheiro e tempo para levar essa criança para passear".

Junto com o aspecto econômico, há outras pobrezas como as de afeto e de falta de estrutura familiar. "É tudo muito difícil. Falta de mãe e de pai dentro de casa. Casam e tem filhos, mas não têm com quem fiquem. Ficam abandonados. A mãe trabalha fora, o pai trabalha fora. Não tem quem olhe os meninos, então ficam soltos por aí”. Ela sabe que esse problema não fica restrito à sua escola e acontece também em outros colégios, mesmo com classe média. Só que ela nota que eles têm outras carências, de afeto, de atenção dos pais, muitos tipos de pobreza e junto com todas essas pobrezas existe a pobreza de recursos econômicos. Sobre a falta de estrutura familiar, existem inúmeras pesquisas que apontam que a estrutura familiar das classes populares é outra, uma vez que se amoldam muito mais ao estilo de família ampliada, em que são incluídos parentes e vizinhança - todos se responsabilizando pela criança. A pesquisa de Lara (em fase de elaboração) ${ }^{56}$ a respeito das organizações familiares das classes populares (2009) constatou que as famílias das camadas populares ampliaram sua rede de apoio no cotidiano familiar, contam com apoio mútuo e desenvolvem relações de solidariedade entre os parentes consanguíneos e os vizinhos próximos.

É evidente que com um clima permeado pela violência do tráfico e da polícia, ao lado da longa jornada de trabalho dos pais, o cuidado das novas gerações fica muito mais difícil de ser realizado.

\footnotetext{
56 Teresa Cristina Lara, em sua tese de doutorado, faz uma abordagem detalhada a respeito das organizações familiares das classes populares (USP, 2009).
} 
Uma religiosa comparou os níveis de pobreza encontrados pela Congregação nas diversas regiões do Brasil e salienta como ainda nas metrópoles é mais vantajoso para as classes populares:

“A pobreza do norte de Minas (onde a Congregação tem outra obra) é uma pobreza diferente daqui do Rio de Janeiro. Aqui as pessoas ainda têm como conseguir algum trabalho para se manter. No norte de Minas as crianças não têm nem isso porque os pais são desempregados ou subempregados porque ganham muito pouco: Um pai ganha 200 reais por mês, quando ganha, fazendo biscates".

A congregação religiosa tem como expectativa que os alunos do Centro Popular Stella Maris sejam mais conscientes, com uma formação permeada por alguns princípios, porque considera que lhes faltem esses princípios: "Realmente é implícito a formação de valores humanos, de educação, de respeito ao outro. Eles vêm de um lugar onde não existe respeito. Então, essa questão do respeito, de relação com o outro. Como é que eles se relacionam uns com os outros. Isso é muito importante”.

Paulo Freire (1996; 2002) assinala que várias são as exigências do ensinar, dentre elas destacamos que ensinar pressupõe uma formação ética. Diz ele a esse respeito:

[...] É por isso que transformar a experiência educativa em puro treinamento técnico é amesquinhar o que há de fundamentalmente humano no exercício educativo: o seu caráter formador. Se se respeita a natureza do ser humano, o ensino dos conteúdos não pode dar-se alheio à formação moral do educando. Educar é substantivamente formar (FREIRE, 2002:37).

A superiora explicou que há vinte, trinta anos, a escola tinha uma conotação mais cristã, com uma linha católica mais tradicional que trabalhava os sacramentos ao mesmo tempo em que fazia catequese, mas que hoje mudou e segue a linha ecumênica da Igreja católica:

"Era uma escola católica e as famílias sabiam que era católica e nos procuravam muito por isso. Agora essa visão é um pouco diferente aqui, porque temos muitos alunos evangélicos e a Igreja também se abriu para o ecumenismo. A Igreja hoje já não é centrada só nela, ela se abriu muito mais. A conotação agora não é exclusivamente católica. Eles sabem que nós somos uma escola católica, mas respeitamos e aceitamos outras pessoas de outros credos que têm os seus valores também. Procuramos nos adaptar a isso também. Então a conotação hoje, mais do que passar a doutrina, é com a formação humana. Por exemplo, hoje nós estávamos conversando com as professoras, falando que no mês de maio, no nosso tempo, fazíamos todas as coroações e procissões. Hoje nós falamos de Maria com muito cuidado para não ferir a crença deles. Sabemos que eles aceitam Maria como mãe de Jesus, mas não tem essa conotação de Maria mãe de Deus. Procuramos respeitar esses valores e sabemos realmente que não adianta querer dar muita doutrina. Tem-se que trabalhar na base, no respeito, na valorização do ser humano. Nós sempre tivemos uma abertura para os pobres, mas não tão intensamente como está sendo agora! A fundadora da nossa congregação tinha esse ideal onde não há lugar para meus pobres, não há lugar para mim”. 
Uma professora, com história recente na escola, notou que as crianças chegavam com sede de conhecimento, sustentando que o colégio oferecia uma entrada no "processo cultural". Acreditava que poderiam "humanizar mais essas crianças", e falou sobre a "degradação familiar" que se via na favela, denotando em sua fala, uma concepção preconceituosa e elitista sobre a educação que deva ser dada às classes populares. Considerou que os pais jogavam a responsabilidade pela educação de seus filhos para a escola: "eles vivem num contexto de muita violência, de deficiência mesmo, de desestruturação familiar muito grande. Então tudo isso realmente reflete nas crianças. Acredito que a escola deve trabalhar a formação moral desse alunado”.

A diretora relatou que outros pais, por estarem fora de casa o dia todo, querem compensar os filhos e dão mais coisas do que eles teriam e poderiam dar. A escola sugere que haja uma troca e se converse sobre os dados de realidade: "hoje eu não posso te dar, deixa eu trabalhar mais um pouco para poder te dar" e pede que os pais ouçam mais os filhos: "Por mais que seja difícil chegar, sentar, ouvir, nem que seja 5 minutinhos de interesse: 'o que você fez hoje? A escola foi boa?' Para dar atenção e valorizar o filho nas suas responsabilidades".

Uma professora comentou que notava "mais educação" na classe média, e atribuía ao fato de terem mais oportunidades de estar nos lugares públicos, situações em que os pais devem ensinar o comportamento esperado, como um teatro, onde as pessoas têm de se comportar de acordo para frequentar o ambiente, , . É preciso observar aqui, mais uma vez, o olhar a partir dos padrões culturais da classe média, como se os padrões de civilidade só fossem adquiridos nestas situações formais de encontro social. Não se pode deixar de notar, entretanto, na fala da professora, que efetivamente essas crianças estão confinadas na favela, sem terem oportunidade de ampliar seus espaços de convivência e de formação cultural:

\footnotetext{
"Essa turma não está acostumada a ir ao teatro, a ir a cinema e ter que se comportar, pois eles vivem em volta deles mesmos. Por exemplo, se eles fossem ao Municipal, se eles tivessem o hábito de ir a um cinema, ir num teatro, ir num lugar para visitar, mas eles ficam muito na favela, presos dentro do mundo deles, sem ter outros espaços de convivência para perceber que naquele espaço se comportam assim, em outro você tem que ver o filme sentadinho porque senão o lanterninha vem te tirar no cinema. São as regras mesmo”.
}

Ressaltou que os alunos atuais não são muito "polidos" e os comportamentos incômodos se manifestam na escola. Atribuiu a falta de educação ao ambiente da favela e à falta da presença materna, embora tenha demonstrado dúvidas sobre suas afirmações, ao tentar fazer generalizações: : 
"Por morarem todos no mesmo cômodo; o pai e a mãe trabalharem fora e não têm a questão dos limites. Mas não são todos. No entanto, a maioria atualmente é sem educação, embora tenham crianças que não parece que convivem na mesma comunidade. Parece que são duas comunidades. Talvez pela mãe ser mais presente, foi educada, foi amada e conseguiu passar isso para o filho enquanto as outras não conseguiram”.

Para professores e coordenadores, as questões de comportamento como a agressividade que aparece no aluno é invariavelmente causada por problemas exteriores à escola, causada por famílias desestruturadas, que não educam adequadamente os filhos e não impõem os limites necessários. A raiz do problema sempre é localizada em sua história familiar e pessoal e explicada por características de personalidade, como maior e menor tolerância à frustração, sem mencionar qualquer interferência da própria escola nesse sentido:

"Mais da falta de contato do que um problema econômico, embora a pobreza e a luta diária sejam agravantes, realmente a falta de recurso material tenha um peso, mas poderia ser minimizado com o interesse na pessoa do filho. Eu percebo que tem uma queixa tanto da família em relação aos filhos como dos filhos em relação aos pais. É falta de diálogo mesmo. Muitos pais vêm para conversar pedindo ajuda na educação dos filhos e é preocupação da escola a formação desses meninos em uma sociedade mais humana”, diz a coordenadora.

Ela não vê diferença quanto às expectativas em relação ao aprendizado da família de classe média e da camada popular, mas, sim, em suas atuações e posturas assumidas no cotidiano em relação aos filhos. Considera que há famílias:

1. cujos filhos terão uma boa educação e um bom aprendizado e vão prosseguir nos estudos; e é função do colégio oferecer estudo e formação a esses alunos, que vão saber se posicionar quando forem para o Ensino Médio em outra escola;

2. que não participam do processo escolar do filho. Não têm compromisso com o filho e é como se falassem para o colégio 'o problema é de vocês'. A escola é uma obrigação que o filho tem que cumprir e ponto. Existe uma preocupação com o filho estar bem assistido, mas a família não comparece à escola.

Thin (2006) a propósito dessa 'ausência dos pais no processo escolar dos filhos', afirma que muitas famílias das classes populares, ou como ele mesmo denomina 'famílias populares', se sentem impotentes e muitas vezes devolvem a tarefa (de regular o comportamento dos filhos) aos professores.

3. que são chamadas a ir ao colégio e que nada acontece. A família trabalha fora, as crianças estão sozinhas em casa e repetem na escola as mesma atitudes que apresentam na vida fora da escola: falta de respeito, palavrão. Quando a mãe é chamada, a mãe diz que é assim 
também em casa. E ponto final. Nada acontece. "Não existe uma estrutura familiar que invista na criança. Eles são sozinhos em tudo”.

A escola, na opinião da diretora, tem tentado amenizar essa falta dos pais, mostrando que estes se encontram fora de casa porque estão buscando dar uma vida melhor aos filhos. $\mathrm{O}$ fato de os pais frequentarem cursos à noite já adultos é consequência de não terem tido a chance de poder estudar na idade dos filhos, mas para ela, a parte afetiva fica prejudicada porque eles são muito pequenos e ficam muito tempo sozinhos em casa. "Eles não têm um apoio da família em tempo integral". E mencionou situações em que ficava evidente essa necessidade do aluno: "ele chega perto e precisa segurar em você, fazer carinho, como para se assegurar da sua presença".

Mas ressaltou que encontrou famílias, também moradoras da comunidade, cujas crianças têm boas experiências, "até porque o Vidigal é uma comunidade na Zona Sul, de frente para o mar e as mães trabalham em casa de pessoas, em princípio, preocupadas com elas e muitas até ajudam a pagar a escola”.

Para ajudar os alunos que não dão conta do conteúdo, ela ressalta:

\begin{abstract}
"Nós temos um tempo maior para esse aluno que precisa de um tempo maior. Acho que possa ser uma questão de falta de incentivo e de uma conversa cultural maior porque muitos deles têm pais analfabetos. Eles vêm sem um determinado conhecimento que eles só vão ter aqui na escola, através dela. Eles precisam de um tempo maior para que eles possam ser incentivados na leitura, na escrita, porque em casa provavelmente eles não têm. Não no sentido de minimizar o seu saber e não penso que por eles morarem em determinados locais como numa favela, ou no morro, ou em um local de difícil acesso eles não tenham capacidade de entendimento ou de compreensão para as aulas. Julgo que eles sejam capazes desde que eles comecem a ser estimulados cedo para poder responder. A escola tem que fazer um caminho para possibilitar que o aluno alcance esse conhecimento, pelo estímulo que ele não teve anteriormente".
\end{abstract}

Uma das professoras entrevistadas também refletiu sobre a questão do tempo do aluno e reiterou que a educação era a única saída para o país. Manifestou a expectativa das professoras de obter respeito dos alunos, o mesmo respeito que elas têm por eles. Acredita que eles não têm assistência familiar, pois as mães geralmente são empregadas domésticas, faxineiras, saem cedo e voltam apenas à noite. Exemplificou com as situações em que pede a assinatura em bilhetes, cujo retorno invariavelmente leva três a quatro dias para ocorrer, pois a a mãe não havia voltado para casa. . Menciona, ainda, que alguns pais são analfabetos e assinam documentos solicitados pela escola, mas sem saber o que estava escrito: 
para responder porque eu sei que ele não tem para quem perguntar. As famílias do Vidigal acham essa escola um oásis e que eles estão criando uma oportunidade para os filhos atingirem ou pelo menos terem a chance de não passarem pela vida da maneira que eles estão passando. O faxineiro talvez tenha expectativa que seu filho possa ser um pouco mais do que ele (pai), no fim qualquer pai quer o que é melhor para o seu filho. Em alguns casos pode ser até mesmo pelo fato do colégio ter uma estrutura grandiosa, qualquer pessoa que entre aqui enquanto instituição escolar, vai se encantar", conclui a professora.

Ela julga que a maioria dos pais não tem cultura por não terem tido a formação necessária e que acreditam que essa escola possa oferecer aos filhos o que a escola pública é incapaz de dar, e que eles mesmos não tiveram:

"Para muitos deles o Rio de Janeiro termina ali na Avenida Brasil. Eles não trazem essa bagagem, o que não significa que a culpa seja deles. Ao colocarem seus filhos nessa escola, querem uma educação diferenciada para os filhos, porque os pais têm como modelo a escola municipal, da qual eles têm horror porque, para eles, significa tudo que não é bom. Já no Stella Maris estariam dando a chance do filho galgar bons caminhos, ter uma educação sólida, completa porque sabem que os professores não faltam, as crianças ficam envolvidas o que não acontece geralmente nas escolas do município nem nas do estado".

"Eles acreditam que aqui vá fazer até um milagre. Alguns pais se surpreendem com os filhose dizem: mas eu não sei por que ela está assim, ela estuda no Stella Maris desde pequena! Como se o fato de estudar aqui garantiria um bom comportamento na vida, não ter certas atitudes, mas acabam tendo porque tem interferências externas e o tempo que eles passam na escola não é um tempo enorme. Mas os pais fazem esforços enormes para manter os filhos aqui por acreditarem que os filhos vão estar mais bem preparados, e esperam uma formação grande e sólida" diz outra professora.

Thin (2006) já observara que efetivamente as famílias populares possuem um fraco capital cultural se medidas pelo conceito de capital cultural no estado institucionalizado da teoria de Bourdieu, ou seja, o número de anos de escolarização dos pais e seus diplomas respectivos.

A entrevistada pondera que os pais, de maneira geral, independentemente da classe social, esperam que a escola eduque os filhos, mas eduque não só na parte cultural ou cognitiva como também dê valores, ensine tudo aquilo que antigamente a família ensinava, ou seja, religião, valores, ética, embora muitas vezes nem deem esse nome. Mas também querem que a escola faça os filhos 'sabidos', educados e felizes. Um desejo que vem junto com a expectativa de que a escola vai dar tudo aos filhos "tudo que não puderam dar e não tiveram". A classe popular espera demais da escola, que possa oferecer educação no sentido de comportamento e educação moral, ao mesmo tempo em que divulga um conhecimento universal, acumulado pela humanidade.

A maioria dos pais atuais fez até a metade do primário antigo, outros são semianalfabetos e eles esperam que os filhos tenham um diploma que lhes dê acesso a trabalhos 
mais "nobres" do que eles tiveram. Uma das professoras disse acreditar que a escola vai dar maior liberdade na escolha da carreira dos alunos e afirma que, no fundo, as famílias querem mesmo que os filhos tenham a liberdade de escolher entre as profissões tradicionais, como, por exemplo, médicos, doutores ou advogados, para ganhar dinheiro de uma forma honesta e sair da comunidade. Muitos deles gostariam que os filhos tivessem essa perspectiva porque, em suas palavras, "comunidade é sinônimo de pobreza"; o que enfatiza o motivo da vergonha de suas origens:

\footnotetext{
"Os pais que escolheram colocar em um colégio religioso e tradicional esperam que o filho cresça integralmente com valores, sabendo ser solidário, tendo uma religião e paralelamente com uma boa formação cultural também. Assim sairia um indivíduo com uma formação integral. Ele está não só esperando que ele saia expert em matemática, química e física, bem como ele seja solidário, saiba trabalhar em grupo e partilhar. A escolha de uma escola com o perfil do Stella Maris leva a esse objetivo" na opinião de uma professora.
}

Para outra professora, fazia muito tempo que os pais da comunidade alimentavam o desejo de colocar seus filhos nessa escola, mas havia bolsa de estudos só para filhos de funcionários e um ou outro aluno da comunidade. Esses pais desejam que o filho tenha uma vida melhor, segundo ela. No entanto, acredita também que algumas pessoas visam alcançar status e completa: "como todo o ser humano tem". Querem melhorar de vida para ter um celular ou um tênis da moda, etc, referindo-se, no caso, ao desejo de consumo envolvido. Notava essa mesma situação na classe média que chegava a se apertar financeiramente por causa disso. Acredita que algumas mães matricularam os filhos só para dizer: "ele está no Stella Maris". Mas também destaca famílias preocupadas com o futuro das crianças e que buscam a escola para a educação de seus filhos, "por uma questão que aqui eles sabem que vão encontrar - uma acolhida melhor", disse-nos ela.

Outras famílias das classes populares saem em busca da escola pública, na opinião da professora, primeiro para não deixar o filho sem estudar e, segundo, para ocupá-lo em tempo integral porque os pais não podem estar presentes, na escola há lanche e sem ônus financeiro.

Em resumo, os professores e coordenadores se sentem valorizados e reconhecidos pelos pais dos alunos que estudam no colégio. Sabem que estão lidando com pessoas que, na sua maioria, tiveram pouco capital escolar, econômico, cultural, conforme salientou Bourdieu, mas que estão em busca de reverter essa situação e de aumentar seu capital simbólico. Para o corpo docente, os alunos são pobres, econômica e culturalmente, necessitando de um tempo maior para aprender, com carência afetiva pela ausência dos pais, que também são ausentes na parceria com a escola, muitas vezes, em razão da absoluta falta de tempo determinada pelo 
excesso de trabalho, e/ou como Thin (2006) sustenta, por saberem e sentirem que essa confrontação é desigual, pois são o polo dominado na relação estabelecida escola e classes populares.

\title{
4.5 - As relações pedagógicas
}

\subsection{1 - O estabelecimento de vínculos}

\begin{abstract}
"Todo educador tem que educar esta capacidade tão essencial de perguntar, que nos impulsiona à vitalidade de pensar, pesquisar, aprender. Assim, o registrar de sua reflexão tão cotidiana significa abrir-se para seu processo de aprendizagem, pois aquele que ensina aprende e é um modelo de aprendiz para seus alunos no seu ensinar". (Freire, M. 2008:70)
\end{abstract}

Um dia, uma religiosa já de idade, dizia a um menino pequeno, que segurava uma barra na mão, que era um risco para ele e para os colegas. Ela argumentou, disse muitas coisas. Em um dado momento o garotinho reagiu e deu uma palmada nela! Ela ficou completamente sem reação, paralisada. Outras crianças reagiram, deram uma bronca nesse menino, dizendo que isto não se fazia. Uma menininha de 5 anos de idade virou para a religiosa e falou taxativa: "Me dê sua mão", e a irmã não teve nenhuma dúvida de que tinha que dar a mão. A garota a levou até a sala de aula e narrou o acontecido a sua professora numa demonstração de vivenciar confiantemente a relação educativa, sabendo que tinha com quem contar, dividir e em quem se apoiar. (cf. POSTIC 1978; 2008).

Postic (2008), ao discutir as relações entre professor e aluno, considera a situação social do meio escolar um espaço, por excelência, no qual a criança ou o adolescente, à procura da identidade, encontra um sistema de forças atuante sobre ela. O estudante está diante de um educador, mas numa situação de grupo, estabelece relações diretamente com o educador e também indiretamente, graças à presença do grupo. Na situação pedagógica escolar a relação afetiva se instaura por intermédio da matéria ensinada, no plano cognitivo, e pelo interesse do professor pelo aluno, no plano afetivo.

No início da pesquisa, a diretora relatou os problemas causados nas turmas do $2^{\circ}$ segmento do Ensino Fundamental com a implantação da mudança de clientela. Na sua opinião era uma questão do pouco vínculo estabelecido entre professor e aluno.

"A Educação Infantil e o $1^{o}$ segmento do Ensino fundamental, de $1^{a}$ à $4^{a}$ série tem um professor à tarde toda e, mesmo tendo aulas extras como música, inglês, ensino religioso, etc., 
o estudante retorna para aquela mesma professora que é referencial para ele. O professor de $1^{a}$ à $4^{a}$ série pode dar uma 'parada' e olhar um aluno com uma dificuldade de outra forma e buscar estratégias para que esse conteúdo possa ser melhor entendido. Do mesmo modo que pode fazer algumas interações entre o conteúdo de história, geografia, português, na própria matemática. De $5^{a}$ à $8^{a}$ tem professor especializado e esses professores quase não se encontram. São oito professores em aulas de 50 minutos e, desse modo, o vínculo fica mais difícil de estabelecer. Mesmo os professores de português e matemática que vêm todo dia na escola, têm seu tempo tomado pelas aulas. Então o tempo que teriam para conversar sobre aquela turma ou aquele aluno fica muito restrito ou não existe".

Ela considera difícil educar nos dias de hoje, "porque vivemos numa sociedade sem exemplos, sem esses valores estarem sendo vividos dentro das pessoas". A dificuldade é maior na faixa etária de $5^{\mathrm{a}}$ a $8^{\mathrm{a}}$ séries, pois os alunos precisam de modelos, uma vez que necessitam concluir suas identificações de infância, mas esse processo é permeado pela turbulência característica da adolescência. E também porque o aluno precisa ter uma relação favorável com o professor, pois após estabelecer um vínculo, diz uma professora, aí, sim, ela vai tentar mostrar a ele o que veio fazer na escola, mas antes acha importante que ele goste dela para romper a barreira do comportamento apático ou desinteressado. Acha que é o único caminho em que consegue chegar perto do aluno e descobrir que ele tem curiosidade para aprender.

Outra professora citou a desvalorização da escola pelas próprias crianças, constatando que a função da escola mudou muito, e que seu valor era preservado somente até a $4^{\mathrm{a}}$ série: "Da $5^{a}$ série em diante muda tudo, menos as aulas de educação física e informática". Estas transcorriam tranquilas, no consenso geral do corpo docente.

Uma professora declarou ter um sucesso muito grande na relação com os seus alunos. Declarou que dá aula há 26 anos e, ao encontrar seus ex-alunos, todos atravessam a rua para vir falar com ela e dizer que tem saudades. Ela acredita que seja porque sempre busca estabelecer um vínculo positivo com eles, apesar de exercer sua função de forma rigorosa, falar alto e gritar, se necessário:

"Em função da minha disciplina (Matemática) ser difícil acho que, caso ainda fosse uma pessoa muito séria, isso ficaria mais difícil ainda, então eu tento criar uma dinâmica de aula mais brincalhona, mais irônica, e, dependendo da série, posso melhorar, inclusive o nível da brincadeira".

Já a coordenadora dos pequenos mencionou que as crianças gostam muito de ir à sua sala "mesmo as que já estão na $5^{a}$ série vêm muitas vezes para contar alguma novidade, algum caso. Gostam muito de ir até a sala da diretora para conversar com ela, que acham que é a dona do colégio!”, demonstrando, assim, como a direção é próxima dos alunos. 
No Conselho de Classe algumas professoras mostravam conhecer bem os casos dos alunos mais problemáticos e traziam suas histórias do passado a partir de séries anteriores. Esse fato nos mostra a qualidade do interesse que essas professoras dedicam aos alunos.

No fim do primeiro semestre observamos o Conselho de Classe das turmas de $5^{\text {a }}$ até a $8^{\text {a }}$ série do ensino Fundamental, no qual estavam presentes a diretora, a orientadora educacional, a representante geral da Congregação das Filhas de Jesus, a coordenadora de religião e 15 professores.

O Conselho começou com as considerações que o grupo fez mediante a leitura da entrevista de José Outeiral: A escola é a solução para a violência ${ }^{57}$. Os professores fizeram uma relação entre a questão da violência e a desestruturação das famílias (referindo-se às diferentes composições de família da atualidade: dois pais, duas mães com figuras de padrasto e madrasta, e a família gay); o mundo com "valores distorcidos", muita impunidade, sem qualquer esboço de reação por parte da sociedade e, nesse contexto, a escola como a única referência para valores, regras, limites e acolhimento, até mesmo para os pais que vinham à escola pedindo ajuda para conseguir criar seus filhos.

Na mesma direção da pesquisa realizada por Mattos (2005), no Conselho de Classe observamos a existência de uma sintonia nas falas dos professores que ratificam mutuamente suas impressões sobre o papel que vem sendo atribuído à escola: "famílias que não assumem seu papel de autoridade e nem exercem sua função de educadores dos filhos" e incumbem a escola para realizar essa tarefa. No entendimento dos professores, a escola assume um papel heróico, e, apesar de se ver assoberbada por tantas funções, torna-se a principal instância socializadora, conforme ressaltou Arendt (1979) em clássico artigo sobre a crise na educação nos anos 60 .

Em seguida, deram início à avaliação do processo acadêmico de cada aluno e aluna e seus resultados escolares.

O grupo avaliava e decidia sobre o sucesso ou o fracasso do aluno, mas eram apreciações subjetivas, observadas pela indefinição ou ausência de critérios avaliativos de cunho acadêmico.

Uma das professoras ao ser entrevistada deu o seguinte depoimento:

\footnotetext{
${ }^{57}$ Revista Globo de 18/06/2006
} 
"Nos conselhos de classe dá até impressão que foi combinado anteriormente. Isso é muito gratificante para o professor, por perceber que a dificuldade ou a característica, por exemplo, da Miriam ter sido agressiva comigo, mas também é com qualquer outro professor que tenta invadir o espaço dela, ou o Homero, que desiste no meio do processo não só em língua estrangeira, mas em matemática. Então isso tranquiliza porque é complicado avaliar uma pessoa. Muitas vezes se chega no final do ano com a cabeça a mil, porque sei que alguns alunos vão acabar repetindo, vão ter que refazer, mesmo que seja uma revisão, mas para mim é um 'ano perdido'. Às vezes tem bom resultado como o aluno acertar o passo, mas nem sempre".

Alguns professores, apesar de considerarem a escola como exemplo, não acham que as famílias a valorizem, e o mérito ficaria por conta do espaço físico. "A escola perdeu seu status e tornou-se a escola municipal Stella Maris, o conteúdo não interessa a eles, só querem uma escola maravilhosa", segundo uma professora.

Outra professora introduz um novo tom no Conselho, ao afirmar que:

"Às vezes as coisas mais insignificantes marcam muito, qualquer gesto pode servir de estímulo (...) Muitos de nós, professores, deixamos marcas, nós vamos ser marcas para outras pessoas, embora a gente não perceba. Somos um pouco o contrário do que eles têm, sabemos o quanto está sendo difícil para as crianças, a sala de aula. Como podemos aliviar isso? Os pais acreditam que ouvimos seus filhos, o pouco que damos é muito e podemos valorizar mais isto sim. Mas onde eles têm espaço? Temos alunos de $2^{a}$ série cuidando dos menores! Dentro da violência somos os únicos a falar em paz, isso é uma questão da escola e dos valores. Quando os alunos voltarem adultos, é que saberemos da marca. O que cansa mesmo é o desânimo, a lamúria, a impaciência, a irritação, mesmo sabendo que é do ser humano. (...) Precisamos pensar no aluno que conta que a mãe estava bêbada por isso ele faltou na escola. Concordo que a função da escola e do professor mudou sim, mas aqui os alunos precisam mais ainda, é necessário exercer bem essa função para alunos que não têm os pais e o conforto que a classe média tem”.

Dubet (1997) questiona essa escola que espera que seu reconhecimento venha de fora.

Se a escola quiser ter sentido seria preciso: "rever os programas e as ambições de um modo que os alunos não sejam colocados
de entrada em situações de fracasso. (...) Não se pode manter programas feitos
para uma pequena elite da burguesia; tanto faz para a elite da burguesia, ela
perderá um pouco de tempo no colégio, isto não é muito grave" (DUBET,
1997:227).

Entretanto o mesmo não deve acontecer com os alunos das classes populares que não têm tempo a perder para conquistar algum lugar na sociedade. 


\section{6 - Formas de ensinar: estratégias e recursos pedagógicos}

A observação de duas turmas transcorreu com pouquíssima diferença, em salas com o mesmo tamanho e mesma arquitetura.

Utilizaremos a designação professor / professora de modo amplo, abarcando todas as professoras, pois não é nossa intenção fazer um julgamento de valor ou uma avaliação institucional nesta pesquisa. Pretendemos retratar situações cotidianas observadas em sala de aula e os exemplos dados na relação pedagógica no ambiente escolar.

Ao entrarem nas salas os alunos e professores encontravam as mesas arrumadas, enfileiradas de frente à mesa do professor. A maioria dos alunos tinha seu livro para acompanhar as aulas, e os alunos que não traziam material não eram punidos e podiam acompanhar com os colegas. Depois que os diversos professores entravam, permaneciam em pé e circulando pela sala constantemente. Faziam a chamada dos alunos (na maioria dos dias todos estavam presentes). Dispunham a sala em semicírculos ou círculos, subgrupos, fileiras, aguardando que os alunos estivessem com o material em cima das suas mesas, abrindo os livros didáticos, e usavam a lousa de giz para apoiar a exposição de suas aulas ou para fazer a correção do dever da aula anterior, fazendo prova, testes, ocupando permanentemente seus alunos. Tudo corria bem. Às vezes o professor levantava a voz e repreendia alguns alunos que estavam entretidos com alguma conversa paralela, que não haviam trazido o dever, ou porque não estavam atentos às respostas que deveriam ser dadas em voz alta. A seguir retomava sua aula expositiva, passando conteúdos da disciplina ou fazendo a correção no quadro. E assim passavam uma, duas, três horas. No total do período eram três aulas contínuas, seguidas de um intervalo de meia hora e mais duas horas de aula.

A diretora apresentou a observadora e sua função em sala de aula. Essa presença despertou curiosidade dos alunos, percebida através dos olhares furtivos, mas sem perguntas. Depois do primeiro dia, nem houve necessidade dos professores explicarem o sentido da observação na sala de aula. Sabemos que a presença de uma pesquisadora que observa a aula interfere na dinâmica da sala; no entanto, como poderíamos nos aproximar do que acontece na classe não estando presentes?

Os professores entravam e saíam sem cumprimentos de ambas as partes. Quando alguma outra pessoa entrava na sala para dar um recado, entregar ou perguntar alguma coisa 
fazia uma entrada informal, a fim de dizer a que veio e saía do mesmo modo (demonstrando que tinham uma autorização implícita). No entanto, dois alunos que voltaram da diretoria entraram em silêncio, e a professora disse: "Peçam com licença para a professora", numa demonstração de haver uma distinção explícita nos papéis exercidos por funcionários e professores em relação aos alunos.

Era um movimento incessante e, para dar conta da aula, tanto o professor como os alunos precisavam de concentração, porque muitas coisas aconteciam ao mesmo tempo, como a transmissão do conteúdo da matéria, a página que seria aberta no livro, a cópia do exercício do quadro de giz, ao mesmo tempo em que o colega ao lado falava alguma coisa e/ou deixava cair um objeto; a professora que repreendia alguém e imediatamente voltava para continuar sua exposição da matéria; a interrupção de um funcionário transmitindo algum recado; a aluna inquieta porque a professora pegou o bilhete e/ou material; a repetição oral do exercício, momento que alguns conseguiam acompanhar e outros ficavam à deriva. O tempo da aula era marcado pelo sinal anunciando seu fim e o início da próxima aula.

A saída e a entrada das professoras eram acompanhadas do gesto de apagar o quadro do mesmo modo que os alunos deviam fazer isso internamente, nesse vai e vem de professores e de matérias. E começava a correção que só terminava no final de todas as aulas.

O dia lá fora lindíssimo, uma vista maravilhosa que até daria para escrever uma boa redação! Porém, atenção! Na próxima semana tem prova de recuperação! E os alunos sofriam a pressão que vem em tom de ameaça! Não dá tempo de olhar para o mar porque quase a metade dos alunos está em recuperação, segundo uma das professoras. Pedia silêncio e os alunos se calavam (ou não). Deviam estar muito acostumados com correções! Um aluno corrigia errado, mas a professora não tinha tempo ou paciência para saber por que ele pensou de outra maneira e seguia em frente. Os alunos ficavam mal comportados. Uma aluna dava um grande bocejo, mas ninguém ligava. E assim prosseguia.

A maioria dos exercícios não exigia reflexão, bastava acompanhar sistematicamente a aula. A professora justificava, avisando que é assim mesmo quando se trata de uma matéria nova, mas advertia: "tem que entender e não decorar!". No meio da exposição repreendia alguma aluna e fazia uma pergunta sobre a matéria para outro aluno, que só dizia: "ai meu Deus!". Os alunos pareciam mais interessados quando a professora fazia as perguntas, menos a título de avaliação e mais em tom de desafio, estimulando-os a explicar algum assunto ou experiência. 
Durante uma exposição a professora comentou algum fato de uma novela da atualidade, uma aluna se animou e todos começaram a falar sobre isso com entusiasmo. A professora permitiu que falassem um pouco sem intervir e depois impôs um limite à discussão: "voltando de novo, matéria, quero que vocês vão para a prova com pouquíssimas dúvidas".

Conseguir silêncio para fazer a correção do dever era muito difícil, e a aula era dada aos alunos que estavam atentos e respondiam às perguntas da professora. Ela anotava o nome dos alunos que não prestavam atenção por estar cansada das tantas vezes que chamara a atenção. No meio das perguntas surgia uma questão que entusiasmava a turma, e eles mostravam querer discutir, empolgando-se, a professora lhes dava espaço e naturalmente eles esgotavam o assunto. Quando algum aluno acertava sozinho qualquer resposta, os colegas incentivavam: aí fulano!

Sentado à frente da observadora havia um aluno à parte da aula, como se nem estivesse em sala. A professora só se dirigia aos alunos participativos ou aos alunos mais falantes. Alguém falou sobre esse solitário, e a professora só disse: "Deixa ele quietinho".

A professora comentou que: "a cada ano os alunos estavam cada vez mais desinteressados", mas como observadoras, refletíamos: - Só os alunos?

Reparamos em outro aluno completamente disperso, deitado na mesa, sem material. Ninguém o incomodou, muito menos a professora. A atitude dessa professora, falando baixo, sem se importar com os alunos desatentos, provocou-nos a impressão de desinteresse pelo aluno. Dubet contou sua experiência do ano que esteve em sala de aula e ensinou jovens de 13 e 14 anos de idade. Essa prática fez com que percebesse a necessidade de o professor trabalhar e mobilizar os adolescentes para transformá-los em alunos. Constatou extraordinárias diferenças nos desempenhos escolares dos alunos:

[...] Somos obrigados a dar aula a um aluno teórico, um aluno médio que não existe, tendo de certa forma o sentimento de que vamos deixar um pouco de lado os bons alunos, porque existem, e que vamos deixar de lado os maus alunos. Outra coisa que me chamou a atenção, são alunos que, depois de dois meses, 'entraram em greve', alunos que nada fizeram. Tiravam zero em todas as provas, não faziam nada, eram muito gentis mas tinham decidido que não trabalhariam. É completamente desesperador: no início eu os puni e no fim não os punia mais, já não adiantava, têlos-ia punido todos os dias (DUBET, 1997: 225).

A entrada de outra professora dá uma nova configuração para a sala, outros subgrupos, cuja distribuição não compreendíamos inicialmente, pareciam já ter um subgrupo na cabeça. 
A professora esclareceu que a escolha dos subgrupos, nos dois primeiros bimestres, ficava por conta deles, mas por formarem 'panelinhas', isto é, alunos se reunirem tendo por critério as notas, nota 10, alunos nota 3 ou 4 e alunos que não entregavam trabalho, dessa vez a turma tinha sido sorteada pela professora, e ela achava que com essa turma funcionou melhor por ter mais integração entre eles.

De um modo geral, a organização do início da aula levou em média uns oito minutos. Novo (velho) aviso ameaçador - avaliação - recuperação. O tempo demorava a passar e ponderamos se seria possível desenvolver um tema em 50 minutos, pois havia um 'mau' aproveitamento do tempo dos alunos e o professor demorava a iniciar a aula, mesmo sem fazer chamada.

Em uma das aulas a professora distribuiu uma prova corrigida, e os alunos mostraram não saber e não entender a pontuação das questões. Um aluno veio nos mostrar sua prova, feliz, havia conseguido 38 e a prova valia 40. Não havia um mesmo critério para a avaliação das provas, os pesos da correção das questões variavam conforme o professor. Alguns professores estabeleciam que a prova valeria 60 e distribuíam os valores das questões que somavam sessenta, enquanto outros faziam a prova valer cem. Já o professor observado fez a prova valendo quarenta. Os alunos demonstraram que não compreendiam essas diferenças, mas se resignavam e nada era comentado com o professor. Não soubemos o motivo de não se ter um critério comum na correção das avaliações a fim de facilitar a compreensão dos alunos.

Enfim, o calendário escolar tem 220 dias e as aulas não variavam muito. Não é à toa que para os alunos, e consideramos o que até para os professores, os grandes momentos da escola são os passeios, as festas, os amigos, etc. Tudo fora da sala de aula!

Todas as professoras tinham como prática habitual deslocar-se pela sala, permanentemente, incessantemente, sem sentar em nenhum momento. A mesa era utilizada somente para colocar o material. Assim acompanham o andamento dos trabalhos.

Os alunos tinham permissão de ir ao banheiro até 9 horas porque ficava no andar de baixo; depois desse horário o pátio é ocupado por outras crianças, mas às $9 \mathrm{~h} 30$ as turmas de $5^{\mathrm{a}}$ e $6^{a}$ séries vão para o recreio. Podiam beber água a qualquer hora porque o bebedouro ficava no corredor da sua sala de aula. 
Uma das professoras comentou que distribuía suas aulas reservando dois dias para introduzir conteúdo e um dia para trabalho em grupo. As avaliações eram distribuídas: uma individual, uma em dupla e uma em subgrupo.

Às vezes o grupo mudava de sala, embora todas possuíssem iguais cenários, isto é, relógio, quadro-negro, crucifixo, imagem de Nossa Senhora e da Madre Cândida, fundadora da congregação, com o dizer: "Sozinha nada posso, mas com a graça de Deus posso tudo".

As atividades em sala de aula durante a observação fazem supor que as marcas que ficarão nos alunos é de que o processo de construção do conhecimento não é uma grande conquista e que submeter-se a ele seja o preço para usufruir sua inserção tanto física, ou seja, no espaço urbano, como social. Essa aquisição do saber é feita com muita paciência, dependendo de um alto grau de concentração para suportar a forma repetitiva das exposições das aulas, exigindo um grande esforço de imobilidade dos alunos em contraste com a movimentação dos professores em sala de aula. Nossa tendência é pensar que, diante da rotina e do cenário escolar, a mudança permanente observada na configuração das mesas e carteiras da sala de aula simboliza a vontade dos próprios professores de que alguma mudança seja realizada, mesmo que seja somente do cenário físico da sala de aula.

Já a dinâmica da aula de informática no laboratório era bem diferente das outras aulas, porque os alunos obedeciam com facilidade às ordens, trabalhavam quietos e concentrados, com explicações da professora no vídeo show. O software escolhido estimulava a percepção, o raciocínio dos alunos e a antecipação do pensamento. O trabalho era individual, cada um em um computador $^{58}$. Os alunos trabalhavam absortos, jogavam em silêncio absoluto e recorriam à professora em caso de dúvida.

Essa observação é bem interessante, pois não existia movimentação na aula e, sim, no computador, porque era preciso obedecer às ordens do software, manter a concentração para ganhar pontos e saber em que nível estava no jogo. Quando havia erro, a professora dava o feedback e explicava onde o aluno havia errado ou o ajudava a descobrir por conta própria. A sala permanecia à meia-luz, os alunos se ajudavam mesmo entretidos na tarefa. Só mostravam, às vezes, impaciência, quando solicitavam a ajuda da professora e tinham que esperá-la terminar de atender o colega. Percebia-se a alegria e o entusiasmo de quem entendia o que era para ser feito no programa e chamava a atenção o enfrentamento da dificuldade dos

\footnotetext{
${ }^{58} \mathrm{O}$ uso do laboratório e da internet era permitido fora do horário das aulas, mediante pedido feito com antecedência.
} 
alunos que, por não conseguirem fazer alguma parte do jogo, chamavam a professora para que ela explicasse novamente. Demonstraram dificuldade em se descentrar e se pôr no lugar do outro, e chegavam a falar com o computador. Não pareciam aprender com o erro a não ser com o auxílio da professora.

Nessa aula a professora era uma aliada que ombreava com eles, junto com os colegas que se ajudavam. Os alunos ganhavam confiança e melhoravam seu desempenho quando a professora permanecia junto deles. Alguns comentaram : "Depois que a gente entende fica uma delícia”. Os que não conseguiam se desestabilizavam e 'argumentavam'(brigavam) com o computador.

Diríamos que o grupo permaneceu tranquilo e nos indagamos sobre essas professoras que conseguiam trabalhar com a turma, se seria porque eram mais experientes e antigas. $\mathrm{O}$ grupo trocava idéias entre si e os alunos ficavam mais motivados. A professora avisava para a turma: "Não adianta dizer que está errado se ela (colega) não entender que está errado".

Nossas observações vão na mesma direção das realizadas por François Dubet, que, depois de uma experiência em sala de aula com adolescentes, percebeu que a situação escolar é vivenciada pelo aluno como uma situação, antes de tudo, de resistência ao professor: "isto significa que eles não escutam e nem trabalham espontaneamente, eles se aborrecem ou fazem outra coisa" (Dubet, 1997: 223). No entanto, conforme constatou, havia possibilidades de se ter uma boa relação com os alunos e mesmo torná-la afetuosa, caso houvesse um efetivo investimento por parte do professor, consciente de que é uma relação que diariamente precisava ser refeita.

Postic, ao discorrer sobre a relação pedagógica, explica:

[...] A procura de um modelo, no adulto, no docente em particular, está associada, no adolescente à necessidade de se enfrentar, de se medir consigo próprio. Inquieto com as suas próprias deficiências, ele investiga num jogo de esgrima o ponto fração do seu adversário para se confirmar a si próprio; quando encontra esse ponto, ele torna-se seu igual. Mesmo sem oposição aberta, o movimento de identificação do adolescente é acompanhado de um gesto de retração de maneira a manter a distância que salvaguarda a sua autonomia (POSTIC, 2007:255-256).

Em uma nova aula, dessa vez dada na horta, em sete canteiros em séries, os alunos estavam aprendendo a cuidar da terra, revolvendo e peneirando, separando o cascalho; a professora dava explicações e fazia perguntas: “Alguém já trabalhou com enxada? Quem sabe a importância da minhoca para a terra?; Por que essa horta é chamada de horta orgânica?Por que é importante regar?" Uma aluna exclamou: "Melhor ficar aqui no canteiro 
do que ficar em sala de aula". Os alunos se divertiam com as minhocas, ao mesmo tempo em que estavam em atividade e assim prosseguiu a aula com a professora que "colocava a mão na massa!" A partir do que o grupo já sabia, ela dizia os nomes das hortaliças e legumes e em quanto tempo se dava o processo do plantio e colheita. Quando eles não sabiam nomear, a professora os desafiava para que sentissem o aroma e, pelo olfato, dizerem o que lembravam. Falou sobre como fazer para melhorar a terra com esterco, sobre o uso de luvas para trabalhar a terra. Depois seguiu com os alunos para o lago para falar sobre tratamento de água, girino, peixe, água doce e água salgada e o encanamento e saneamento das águas e esgoto.

O ponto de partida da educação escolar são saberes que alguém instituiu como importantes de serem ministrados homogeneizadamente em um determinado momento para todos. O professor tem saberes que deve transmitir aos alunos. Houve modificações imensas nos últimos 30-40 anos, mas que retiraram seus fundamentos deste modelo, de acordo com o qual as relações estabelecidas anteriormente eram condição para a eficiência desse tipo de orientação de ensino.

Conforme Guimarães (2008) ${ }^{59}$ assinalou, o exemplo acima se coloca exatamente como uma inversão do modelo de educação escolar. O ponto de partida da atuação desta professora, quando ocorre a atividade, não são saberes. O ponto de partida é a atividade e é ela que vai mobilizar saberes. É uma inversão sumamente importante e isto terá efeitos diferentes dos efeitos que o modelo chamado de educação escolar produz, seja com o aluno pobre, seja com o aluno rico (entendendo a educação como ensino nesse sentido).

Segundo Libâneo (1983), a pedagogia liberal sustenta a idéia de que a escola tem por função preparar os indivíduos para o desempenho de papéis sociais, ou seja, adaptar os indivíduos aos valores e às normas sociais vigentes, e preparar os alunos para assumir sua posição na sociedade. O autor explica que a doutrina liberal apareceu para justificar a predominância da liberdade e dos interesses individuais na sociedade, estabelecendo uma forma de organização social baseada na propriedade privada dos meios de produção, também chamada de sociedade de classes. Segundo Libâneo (1983) existem formas distintas relacionadas a maneiras diferentes de como se pode promover a aprendizagem dos alunos, a saber:

1. através da centralização da condução do processo de ensino-aprendizagem na sua autoridade - pedagogia liberal conservadora;

\footnotetext{
${ }^{59}$ Banca de qualificação
} 
2. através da ênfase no processo de desenvolvimento cognitivo do aluno - pedagogia liberal renovada progressista;

3. uma última, através da ênfase nos processos de desenvolvimento das relações e da comunicação, deixando num segundo plano a transmissão de conteúdos - pedagogia liberal renovada não-diretivas.

Na história educacional brasileira a tendência liberal conservadora é, segundo Libâneo (1983), viva e atuante nas escolas brasileiras, aqui incluídas as religiosas ou leigas. Esta orientação fundamenta-se nas idéias de Durkheim, assinala Fevorini (1998), e seu modelo de aprendizagem ocorre por meio da coação, ou seja, imposta de fora para dentro. Ela parte da tradição cultural e caracteriza-se por acentuar o ensino humanístico, de cultura geral com aulas nas quais predomina a palavra do professor. Os conhecimentos e valores sociais acumulados pelas gerações adultas são transmitidos ao aluno como verdades. Seus métodos baseiam-se na exposição oral da matéria e/ou demonstração. Não existe a relação professoraluno e seu relacionamento é definido pela autoridade do professor, que exige uma atitude receptiva dos alunos e impede qualquer comunicação entre eles no decorrer da aula. "A disciplina imposta é o meio mais eficaz para assegurar a atenção e o silêncio" (LIBÂNEO, 1983: 13). A retenção do material ensinado é garantida pela repetição de exercícios sistemáticos e recapitulação da matéria. A avaliação se dá por verificações de curto prazo (interrogatórios orais, exercícios de casa) e de prazo mais longo (provas escritas, trabalhos de casa). O reforço é, em geral, negativo (punição, notas baixas, apelos aos pais); às vezes é positivo (de classificações).

Normalmente os alunos devem entrar disciplinadamente, no horário, fazer corretamente o que a professora manda, todo mundo quietinho, e fazer bem. Não pode falar com o outro para não atrapalhar a aula. Mas quem desempenha, em uma aula deste modelo, não é o aluno. A ação pedagógica desempenhada dentro desse modelo é a ação de quem ensina, não de quem aprende! Quem ensina, aliás, é alguém que não aprende.

Essa inversão do modelo de educação escolar cuja atuação é do professor não invalida de modo algum o peso da diferença de origem social, mas, neste caso, esta diferença assume outras características. O cerne da questão é que estamos procurando o substrato de mutação social, a modificação das relações sociais, de maneira geral, das relações entre gerações, do exercício de autoridade em meio a um processo determinado por inúmeros fatores, que é a 
educação. E, no caso de nossa pesquisa, é um pouco mais complexo por se tratar de um ensino laico dado por uma instituição religiosa que fez opção pelas classes populares.

De volta à sala de aula rotineira, ao sinal da saída, rapidamente os alunos guardavam seu material, mas algumas professoras pediam que continuassem sentados e organizavam a saída em grupos de três em três alunos depois de arrumarem suas cadeiras. Toda essa organização deixava aflitos os alunos que iam com a condução escolar. Acreditamos que eles eram responsabilizados e repreendidos por um eventual atraso pelos responsáveis dos ônibus.

A aula consistia em conteúdos, correção, ameaças e repreensão. Assim se esgotavam os cinquenta minutos na relação professor e aluno.

"Eu acho que tem gente falando o tempo todo. Chega na hora da avaliação não conseguem
fazer! Lógico, não estão entendendo. Vou dar 12 minutos para tentar fazer. Não quero ouvir
uma palavra, exatamente daqui a 12 minutos, quatro minutos para cada exercício. Ninguém
falando, quem já fez eu vou ao lugar ver. R.! Olha os modos!".

E a professora se movimentando, e algum aluno sempre querendo atenção. Não são os mesmos alunos, são diferentes alunos para diferentes professores. No meio da aula uma aluna diz: "Eu vou para Salvador!”, expressando seu desejo de viajar, passear. O grupo prestava atenção e um deles comentou: "É legal". Mas logo, demonstrou sua apreensão em relação ao rendimento escolar: "Acho que não vou porque estou mal na escola". E outro retrucou: "Você fala que vai e depois diz que não". Ela respondeu: "Estou mal, não posso faltar na escola".

A professora passou mais dever para copiar na agenda, a turma estava falante e a professora buscava atenção batendo palmas e, em seguida bateu na mesa, perguntou para cada um o que estava acontecendo e os alunos se acalmaram. Então apagou o quadro, começou a chamar cada aluno e entregou as provas corrigidas. Nesse momento, todos ficaram atentos e comentando as suas notas com os colegas. Começou o barulho novamente e essa foi a dinâmica da aula com a professora tentando repassar a prova, tecendo comentários, mas sendo interrompida várias vezes. Fez intervenções, bateu no quadro e disse em tom de reprovação: “Preciso de atenção!”. E acrescentou: “J. não faça bola com chiclete em sala, vá cuspir esse chiclete!". (A aluna vai devagar). A professora ameaça: "Vocês vão ficar aqui, no recreio, para que eu possa corrigir".

Pode-se dizer que a escola reconhece a si própria como uma instituição enfadonha. Do contrário, por que escolheria tirar o recreio ou reter seu estudante por mais tempo na escola, como punição? Com essa atitude, a instituição se revela e se assume como castigo. 
A aula fica esvaziada de sentido por não haver relação com a vida dos alunos! O único feito é alcançar uma boa nota na prova para passar de ano. E a professora continuou: "Psiu! Por isso não aprendem nunca, não tem concentração. Essa matéria tem vários caminhos, porém o resultado é único". De 14 alunos, dez conseguiram passar na prova de recuperação. A professora foi falando a nota da prova alto pelo número do aluno na chamada: " $n{ }^{\circ} 18$ ficou com média 58; $n^{\circ} 19, n^{\circ} 20, n^{\circ} 24$ parabéns! A nota foi ótima: 74”. "Com o teu esforço ninguém vai te segurar, tem que ter garra". Uma aluna fez um comentário: "Eu não consigo!" Ao que a professora respondeu: "Se estudar você aprende, o seu resultado é o resultado do seu interesse pela disciplina".

A ideologia do dom enaltecia os bons resultados de alguns alunos e os que não conseguissem alcançar boas notas eram taxados de fracassados pois não tinham se esforçado o suficiente para tanto. Ora, a força de vontade não é bastante para os alunos em geral conseguirem bons resultados na escola. Até a abertura da escola para todos, somente as classes abastadas conseguiam ingressar na escola, e os critérios adotados eram, então, estabelecidos pela riqueza ou pelo nascimento. Com a democratização da educação, a igualdade de oportunidades e a importância do sistema escolar para garantir igualdade social a todos os alunos consequentemente possibilitaria de fato maior justiça social. Dubet (2004), porém, critica a escola meritocrática, que se atém aos que apresentam melhor resultado. A escola para ser como uma escola justa, aponta Dubet, deve se preocupar com a questão da diversidade dos seus alunos, porque senão tecerá sua própria armadilha ao estabelecer que os alunos mais dotados são os melhores; a meritocracia contradiz o princípio da igualdade que rege uma democracia igualitária. Considera que o critério meritocrático não é suficiente para diminuir o impacto das desigualdades sociais, pois a escola que verdadeiramente está em busca desse ideal de igualdade deveria garantir a todos os seus alunos um mínimo comum de conhecimentos e competências, preocupando-se principalmente com a integração social dos alunos na sociedade. E mais ainda, poderia permitir a cada aluno desenvolver seus talentos específicos, independentemente do seu desempenho escolar. Ora, o mérito não assegura a diminuição das desigualdades sociais e a integração social pode efetivamente reforçar o destino social dos alunos; o consenso de um mínimo comum de conhecimentos pode servir para limitar a expressão de aptidões. A instituição escolar deveria estar atenta e consciente de que, na tentativa de lidar com a desigualdade social dos seus alunos, poderia estar camuflando os problemas em vez de enfrentá-los propriamente. 
A aula de Educação Física ocorreu com a turma dividida: as meninas indo para uma quadra e os meninos para o pátio, sem ninguém precisar avisá-los. Na quadra todas se sentaram no chão em filas e a professora fez a chamada. E, assim, já havia transcorrido 10 minutos quando a aula começou. As alunas se organizaram e fizeram aquecimento. Um time de um lado e outro do outro. A professora fez rodízio entre as alunas para que todas tivessem a oportunidade de jogar. Era uma aula que parecia um treino, bem disciplinado e organizado porque com o jogo em andamento uma jogadora saía enquanto outra entrava! Quem não acertava, no entanto, ficava bem exposto. Houve alunos, por exemplo, que mesmo antes de tocar na bola já anunciavam: "Vou errar", antecipando seu suposto fracasso. Todas esperavam pelo apito.

O erro massacra no esporte. É sem contemplação e é visto por todos. Uma aluna que tinha tentado chamar a atenção da professora em outra aula estava de juiz da partida e seu desempenho era ótimo. Se um aluno está precisando de atenção qualquer papel é melhor que nada, pode ser ir para a secretaria ou ser juiz, qualquer coisa que ele sinta como uma forma de atenção por parte do adulto

Os alunos iam para o recreio, que era bem organizado. Jogavam vários esportes, compravam lanche na cantina e ao sinal voltavam suados para a sala de aula. Assistiam às aulas e a professora tinha dificuldade para conseguir silêncio! Os alunos abusavam do barulho e doze minutos se passavam para a professora começar a tarefa. Essa professora comentou que os alunos tinham dificuldades para trabalhar em subgrupos. Pensei, nesse momento, que seria interessante que os professores pudessem observar seus alunos com outros professores para ver se confirmariam o que diziam. Em alguns casos, os professores supunham ser uma característica do aluno e não refletiam sobre a participação de sua prática docente no ambiente de trabalho em sala de aula.

Essa professora atribuía a agitação do grupo à aula de Educação Física, e, em parte, poderia ter razão. Fez a atividade com os alunos ao mesmo tempo em que comentava que o trabalho de casa não era estimulado e que eram orientadas para que os deveres fossem feitos na escola.

De certa forma os alunos tinham um limite interno, porque apesar de resistirem, até que se comportavam. Por exemplo, nessa aula havia três alunos em pé e que iam ver o trabalho de outros subgrupos, mas havia outros 25 alunos sentados. 
Mais um dia com prova, com 27 alunos na sala e a professora deu as orientações para a realização da prova:

\footnotetext{
"Vocês têm que aprender a fazer avaliação porque isso fará parte de suas vidas. Não serão avaliados só aqui no colégio. Atenção, a partir do momento que a avaliação for distribuída vocês tem que ficar quietos. Avaliação é um documento. Deem uma olhada rápida na prova enquanto eu vou abrir as janelas para refrescar a sala, que com as janelas fechadas é para sentir calor mesmo".
}

Todos em silêncio e a professora explicou cada questão, com a voz em tom natural e calmo, e permaneceu sentada. Os alunos fizeram a prova com as carteiras em fileiras.

A seguir, a professora se levantou e passou de mesa em mesa orientando os alunos. "Se você não ler a prova, as coisas não darão certo. Até um cartaz avisando que tem um buraco, se você não ler, cai no chão".

Nas diferentes séries havia muito conteúdo, e muita queixa dos professores porque os alunos não estavam aprendendo. Não havia uma ação efetiva para que os alunos fizessem relações entre os diversos saberes que os auxiliassem a melhorar seu desempenho escolar. Uma professora, que se demitiu, era também uma pessoa com dificuldade. Ela poderia ser vista como um aluno que se demite por não dar conta da tarefa. É função do professor ensinar seu aluno e avaliar se este está aprendendo. O professor parece pensar que o aluno que não aprende é por culpa própria, o que aprende é porque é bom aluno e aprenderia em qualquer colégio. Desse modo o professor fica sem função, e surge a questão: em qual momento o professor sente que exerce realmente um papel no processo de aprendizagem discente?

Entra outra professora e novamente faz-se a arrumação da sala. Dessa vez, pediu que arrumassem a sala com as mesas de dois em dois. Uma aluna falou que preferia em semicírculos, mas a professora avisou que queria subgrupos. Mais tempo para arrumar a sala. Sete minutos depois e a sala ainda não estava pronta. A professora mostrou revolta com a professora anterior por não ter deixado a sala arrumada. Nesse vai e vem das carteiras, eu me pergunto: O que seria uma sala arrumada? Comentou: "Acho o fim do mundo". Doze minutos e ainda arrumando. Fechou as portas, ligou ventilador, uma aluna levantou e desligou. Os alunos estavam divididos em duplas e trincas. A professora pediu que abrissem o livro numa página e recapitulou com perguntas o que já deveria ter sido lido. Alguns alunos 'chutavam' a resposta e a professora advertia: "aqui não é bingo". 
Nessa aula, a aluna que gostava de chamar a atenção começou a se manifestar novamente: "Eu ia falar, mas ele me interrompeu". Ao que a professora respondeu: "Você hoje está descontrolada, se controla, está perdendo a graça”.

A professora, junto com os alunos, perguntava e eles respondiam. Quando acertavam davam vivas em uma demonstração de satisfação. A docente problematizava o conteúdo dessa aula e dizia o que era para sublinhar (mostrando o que é importante da lição), enquanto chamava a atenção dos alunos "L. não vou falar mais, vamos iluminar a leitura do texto".

Essa aula foi o típico exemplo de uma aula centrada no professor: leitura do texto, iluminar (usar pilot-marcador para 'iluminar' as partes mais importantes do texto), virar a página, continuar iluminando. Chamava a atenção de outro aluno: "P. sai daí e venha sentar aqui antes que eи me irrite". Pediu que um aluno lesse, repreendeu outro que reagiu, ao que a professora respondeu: "R. está difícil, vira a página”. "R. para com sua cadeira!”. Os alunos estavam agitados. Um aluno jogava com raquete uma borracha. A professora a tirou da mão do aluno. Todo mundo queria falar alguma coisa. A pauta foi anunciada: Eleição na cidade para governador, e um aluno disse: "Até que enfim!" A professora falava e falava e faltavam ainda seis minutos para terminar a aula. No final da aula, avisou: "Semana que vem - prova individual". Um aluno fez uma pergunta, e a professora respondeu beirando a indignação: “Que dia? Eu mato vocês! Cadê o calendário?” Depois fez uma nova seleção da divisão dos subgrupos para o próximo bimestre.

Passou, então, exercício para casa e avisou que os alunos podiam guardar o material. Estes responderam com gritos de alegria, que a professora cortou, dizendo: "mas ninguém vai descer para o recreio!” Ela apagou o quadro. Hoje teve um mínimo de aula. Todos saíram com a professora ainda em sala.

Há trinta e dois anos Paulo Freire escreveu seu livro, Pedagogia do oprimido, onde analisou as relações educador-educandos na escola. Ele já apontava a tônica da educação ser preponderantemente de narrar, sempre narrar, e as relações pedagógicas apresentarem um caráter essencialmente marcado por relações narradoras, dissertadoras, ou seja, nas suas palavras: "narração de conteúdos que, por isto mesmo, tendem a petrificar-se ou a fazer-se algo quase morto, sejam valores ou dimensões concretas da realidade. Narração ou dissertação que implica um sujeito - o narrador - e objetos pacientes, ouvintes - os educandos" (FREIRE, 2005:65). O modelo tradicional de educação, nomeado de educação 
bancária, em que o ato de educar seria equivalente ao ato de depositar, de transferir, de transmitir valores e conhecimento.

No recreio estive com duas professoras que falaram da 'má-educação' dos alunos. Ilustraram o que diziam referindo-se à maneira como gritavam uns com os outros: "Tudo querem sair no tapa". Uma delas relatou ter trabalhado em outra escola com a classe média e que via diferença até no tom da gritaria: "Esses são mais rudes", e justificou: "pudera, são tratados assim pelos pais, eles aprendem desse jeito, mas é um horror. A vida só dá pancada neles, então acho que é a maneira deles enfrentarem!"

Nesse intervalo outras duas professoras conversaram informalmente sobre déficit de atenção e dificuldade de apreensão da matéria por parte dos alunos. As professoras culpabilizavam o contexto em que viviam e pareciam não acreditar na capacidade dos alunos para aprender, enumerando as dificuldades encontradas: o fato de não terem pais, ou por não terem instrução, os alunos serem subnutridos e o contexto violento da comunidade, com tiroteios permanentes.

Patto (1997) já identificava essa problemática nas interpretações que eram feitas na escola do rendimento das crianças das classes populares:

[...] Outros rótulos têm sido usados (desprivilegiados, culturalmente diferentes, classe operária, crianças do centro da cidade, etc.) para designar, de maneira ampla, um segmento da população geralmente considerado vítima de algum tipo de falta de oportunidade ou de infortúnio. Todos estes termos padecem de um mesmo dilema: como se referir a uma parte da sociedade que possui relativamente pouco prestígio, status, poder e outros recursos básicos, sem aumentar seu infortúnio, estereotipandoa e sugerindo que seus membros são inferiores quando avaliados em função de alguma norma de comportamento de classe média. (PATTO, 1997:85)

$\mathrm{Na}$ aula de informática, os alunos pareciam concentrados, todos absortos, sentados com fone de ouvido. A professora explicou o que seria preciso fazer no jogo do computador usando o movimento do corpo. A aula correu tranquila, alunos trabalhando e a professora atendendo conforme as solicitações.

Começou, então, a última aula do dia com a professora tirando dúvidas do conteúdo para ajudar na prova. Um aluno olhou para trás e outro retrucou: “Caramba, vai quebrar seu pescoço". A professora começou sua exposição, precisou chamar a atenção do aluno que estava virado para trás, os colegas o cutucaram, ele se levantou, enfrentou o grupo do lado, eles "roubaram" seu estojo e jogaram no chão. A professora chamou a atenção: "Bonitos, inteligentes e aprontam isso em sala de aula?" Ela ia de grupo em grupo para falarem as 
frases e nesse vai e vem ouviu um palavrão. Advertiu: "Acho isso um absurdo. Ou você vai expulso ou para de vez". E ameaçou com prova: "Dia 21 vocês têm prova e a prova vai ter muito mais coisas que a prova anterior, é cumulativa, não vão ter média, vão ficar com nota baixa".

No fundo da sala um grupinho conversava sem nenhum constrangimento. No meio da aula um aluno levantou-se e jogou papel no lixo. A professora observou jocosamente: "Cara, você é lindo, lindo, queria ser como você”. Em seguida, pediu que os alunos levantassem e escolhessem com quem queriam trabalhar: "Coloquem as cadeiras de frente um para o outro". Os alunos se agitaram, mas cumpriram a proposta. A coordenadora entrou na sala e os alunos silenciaram espontaneamente. Ela deu recado para um aluno e saiu em seguida. Os alunos trabalharam mesmo agitados. A professora comentou que está substituindo uma colega e tem sentido resistência por parte dos alunos, mas mesmo assim tem conseguido trabalhar com eles.

Uma das vantagens dessa escola é contar com a mesma equipe durante o ano, e de antemão já saber com quem vai dividir a turma dos alunos. As equipes de professores conseguem ter um cotidiano compartilhado por todos, e a escola e todos os professores sabem com quem dividirão a tarefa escolar. Diferente da escola pública em que os professores são nomeados por "critérios objetivos e impessoais" (para não haver favorecimento, dá-se prioridade à classificação), mas que cria um problema, pois os professores não conseguem organizar suas vidas, uma vez que muitos não têm idéia para qual escola será designado e também pouco contribui para a constituição de um corpo docente estável. Dubet (1997) ressalta que para uma instituição de ensino conseguir ter um bom desempenho (e alguns colégios conseguem) é importante que possa construir seu quadro educativo com uma equipe formada por professores atraídos para trabalhar em um determinado estabelecimento de ensino em função de um determinado projeto pedagógico (DUBET, 1997).

Destacamos alguns dos fatores científicos relevantes para o bom funcionamento de uma escola, que estão relacionados com a autonomia de gestão de estabelecimentos, a flexibilidade de seu funcionamento e de composição do corpo profissional. Organizar uma escola anteriormente ao início do ano letivo, por iniciativa própria, distribuir as aulas segundo as orientações escolhidas, procurar constituir um corpo de profissionais que tivesse compatibilidade entre si e com essas orientações, isso é absolutamente inimaginável em termos do funcionamento de escolas públicas, ao menos, na atualidade. 
No projeto da escola pesquisada, encontramos a composição do corpo docente com um projeto comum, coordenado com todo um funcionamento da escola segundo os padrões acima descritos. A inovação do trabalho desenvolvido nesta escola é que seguia os padrões das melhores escolas particulares mas que atenderia as crianças das comunidades vizinhas dos morros. Então, conhecer o que está sendo feito especialmente com o que se chama de camadas populares por escolas particulares pode contribuir muito para compreender aspectos como esses relativos à composição docente e ao modo de funcionamento da escola, para que se possa analisar os resultados obtidos em práticas educacionais inovadoras como essas, os ajustes necessários em seu funcionamento, as contribuições do corpo profissional, e as modo dificuldades advindas da diferença social e valores culturais entre docentes e estudantes.

Quanto às aulas, não é de se estranhar que as atividades relacionadas à Educação Física e de Informática transcorram de forma tranquila. A primeira requer o trabalho disciplinado e, ao mesmo tempo, lúdico, que envolve muito prazer entre as crianças e jovens, por trabalhar o corpo e o jogo, que aliado ao convívio com o grupo de pares, torna-se a aula preferida dos alunos. Não se pode esquecer que a possibilidade de aprender a lidar e a desafiar e conhecer o próprio corpo e deste em relação aos demais é muito diferente do que exige a maioria das disciplinas que requer grande atividade intelectual individual. Não se pode esquecer que a possibilidade de aprendizagem dos esportes e suas regras, tem sido bastante valorizada pela mídia, inclusive como forma de ascensão e valorização sociais.

Em relação à Informática, as pesquisas desenvolvidas pelo Núcleo de Orientação e atendimento psicopedagógico - NOAP - da PUC-Rio apontam que o computador, como um recurso psicopedagógico, tem um impacto positivo na estruturação e organização do pensamento de crianças e jovens, que propicia situações de construção de conhecimento tanto individual como grupal. Apresentamos alguns dos seus resultados:

- demonstra que a concentração aferida, no trabalho com o computador, não é algo a ser treinado mas, sim, "uma conduta despertada a partir do interior do indivíduo, motivado no seu interesse" (Vasconcellos: 1993:99);

- $\quad$ cria situações que favorecem o processo de aprendizagem por oferecer uma função organizadora dos conhecimentos;

- $\quad$ evidencia maior disposição para o enfrentamento dos erros e maior cooperação no grupo. 
Gostaríamos de destacar uma das conclusões da referida pesquisa, que pondera o seguinte: "O computador é infinitamente paciente, não faz caras feias ou bonitas, críticas positivas ou negativas o que facilita ao usuário maior liberdade de exploração, em que o indivíduo fica entretido em uma conversa entre ele mesmo e o seu único e singular processo de aprendizagem na construção do seu conhecimento" (VASCONCELLOS, 1993: 101).

Resta saber se a escola desempenhará esse papel de auxiliar o processo de construção do conhecimento dos seus alunos no sentido de abertura para o mundo - uma vez que os apelos consumistas e os modelos que servem como referência para os jovens nesse mundo em que até mesmo o sentido do humano está sendo posto em xeque - tudo concorre com um modelo de escola antiquada, que define a aprendizagem como algo extremamente linear, um passo a passo, que vai do mais simples ao mais complexo, do mais concreto ao mais abstrato. A escola baseada no falar/ditar do professor, em que prevalecem as estratégias tradicionais, com aulas expositivas, na maioria das vezes, com o professor explicando, corrigindo e seguindo à risca o livro didático com seus conteúdos 'ditos universais', de frente para os alunos, que devem permanecer silenciosos, copiando.

Para Pierre Lévy (1993), vivemos atualmente em uma nova sociedade - da Informática, pós-industrial e, em consequência, há um paradigma emergente na Educação, segundo o qual as novas gerações se utilizam de outros modos de aprendizagem baseados em estruturas não lineares, completamente diferentes da estrutura sequencial em que se assenta o currículo escolar contemporâneo (LÉVY, 1993:10).

Forquin (1993) questiona essa escola que pretende dar conta das desigualdades com o discurso de que todos os alunos são iguais. As professoras têm diante de si um aluno cuja performance é desigual, e para o qual a escola não está preparada.

[...] São frequentemente alunos com capacidades intelectuais limitadas, mas não sempre, não necessariamente, pois muito frequentemente também se trata de um problema de ordem cultural mais do que cognitivo: existe um conflito latente entre as orientações, as atitudes, os valores culturais que eles devem ao seu meio familiar e social e as exigências implícitas da cultura escolar, pelo fato de que esta põe ênfase numa abordagem essencialmente intelectual e livresca do mundo (FORQUIN, 1993:50).

\subsection{1 - Cenas do cotidiano escolar}

\subsubsection{1 - Pequenos gestos}

Chamamos de pequenos gestos a atitude, por parte do professor, que pode auxiliar na formação do vínculo com os alunos e na valorização destes, quando sentem ser objeto de atenção do professor cuidadoso. Dubet (1997) realçou que os alunos eram sensíveis ao fato de o professor se interessar por eles, como pessoas, significando que sabia seus nomes, falava com eles, lembrava de suas notas e também de suas histórias. Observamos que muitos professores nomeavam seus alunos, estavam envolvidos com eles, sem ficarem 'presos' ao drama familiar, mesmo sabendo de sua vida privada. 
Apresentamos, a seguir, alguns exemplos nesse sentido, encontrados nesta escola:

No laboratório de informática a professora destacou a capacidade musical de uma aluna que era considerada fraca. Pediu a ela que ajudasse uma colega sua, considerada 'sabida', em uma fase do jogo, e outras colegas se surpreenderam com o saber dessa menina 'fraca': "Nossa, ela fez tudo isso?" Depois a aluna 'sabida' agradeceu a ajuda e ela voltou tranquilamente para o seu lugar. Observei essa professora capacitando os alunos, entendendo a dificuldade, procurando ajudar, com estímulos e elogios: "muito bom! Está desenvolvendo bem hoje!" E brincou com outra aluna: "Acho que esse lugar aqui te deu sorte!”. Anotou os pontos dos alunos no programa: "Pode ficar tranquila. Não vou deixar você perder nada". A aluna agradeceu. Tocou o sinal, a turma desligou seus computadores e a professora se despediu: "Até a próxima semana!”.

Outra professora entrou na sala se desculpando pelo seu atraso e dando notícias de um passeio que iriam fazer na semana seguinte...

Os alunos foram avisados de que não haveria a $4^{a}$ aula porque a professora fora acompanhar um grupo de alunos a um passeio.

Era o primeiro dia em que estavam juntos, com a mudança do semestre. A professora perguntou sobre as férias, estimulando-os a contar sobre as férias, e comentou sobre as mudanças e os sentimentos suscitados por serem desafiados com situações que envolveriam fatos novos.

No término da aula, próximo do final do ano, a professora se despediu dos alunos desejandolhes boas férias...

No meio da exposição, a professor repreendeu uma aluna que estava com um bilhete que nãoera pertinente à matéria.Tomou o bilhete e avisou : "Vou devolver na saída. Vocês sabem que eu sempre devolvo”.

Ao soar o sinal, a aula termina, a professora se despede dos alunos e eles respondem.

A professora ensinava como pegar a bola, como sacar, corrigia, incentivava, elogiava, aplaudia. Organizou o final do jogo, cumprimentou as equipes, todas em fila...

Entrou outra professora que perguntou como foram na prova anterior.

Foram avisados de que não teriam aula de futebol.

A professora terminou a aula, falou sobre o dever, despediu-se e saiu.

Um colega diz: professora fulano está chorando! Todos ficaram em silêncio e olharam para ele. Impressionava perceber como eles estavam atentos, apesar de aparentemente dispersos. Uma aluna foi abraçar o aluno quieto.

Na sala de aula chegou um aviso sobre uma aluna que estava faltando, e a professora perguntou aos alunos se sabiam o que estava acontecendo, pediu que procurassem saber e a informassem.

Usou o quadro de giz para dar exemplos e servir de apoio para sua aula. Todos discutiram sobre a mulher nos empregos, referindo-se ao que observavam na cidade: motorista mulher, jogadora de futebol...

Um aluno levantou para falar com a professora enquanto outro pedia: "Professora, vem cá, por favor", e ela foi. Um aluno pediu caneta emprestada, ela emprestou, mas antes experimentou para verificar se funcionava.

Acreditamos que esses pequenos gestos favorecem que os alunos se sintam dignos de respeito e de interesse. São gestos que auxiliam a construção de uma auto-imagem positiva, 
pois os alunos se percebem merecedores da atenção de uma autoridade reconhecida na figura do professor. Já a falta de confiança básica leva a uma grande necessidade de aprovação do adulto. A confiança básica, segundo Erikson (1976), é entendida como “uma segurança íntima na conduta dos outros, assim como um sentido fundamental de boa conceituação própria" (ERIKSON, 1976: 97)

\subsubsection{2 - Para que serve a chamada}

\footnotetext{
Uma professora começou sua aula fazendo a chamada e, ao observar a presença maciça da turma, comentou: "Os alunos faltam muito, mas hoje estão todos presentes, inclusive tem um aluno que eu não via há duas semanas.”

A professora fez a chamada, demonstrou surpresa com todos os alunos em sala de aula e disse:

"Faltam muito", ao invés de valorizar a presença deles naquele dia.

Outra aula e, dessa vez, a professora só contou os alunos, viu que todos estavam presentes e essa foi a chamada.

As alunas respondiam a chamada em bloco.
}

Madalena Freire ${ }^{60}$ assinala que a cada chamada valoriza-se o fato de o aluno estar presente e vir se assumir como estudante. Para que a chamada possa ser trabalhada como um instrumento pedagógico, é preciso que o professor recrie esse momento. A primeira atividade de cada aula é a chamada. Cada aluno é um e é importante que o professor veja cada um. Todos têm competência e capacidade para aprender, mas o corpo mostra os problemas de aprendizagem, o corpo fala, mostra o que sentimos. Olhar o estudante, observá-lo é importantíssimo e a chamada diária é o momento que possibilita ficar atento para olhar cada um. Expressa o respeito que o professor tem pelo grupo e cada aluno deve perceber a sua importância nele. Pode representar um jogo de reconhecimento em que o professor é desafiado a memorizar cada um, trazer seu aluno para dentro de si e, com isso, estabelecer vínculos. Não deixa de ser uma forma de lembrar todos, tornando-os presentes desde o início. Mas quando o professor faz a chamada de um modo enfadonho, apenas como uma tarefa burocrática, ou quando conta o número de alunos presentes em sala de aula, o processo de reconhecimento do aluno deixa de existir, assim como se perde a oportunidade de estabelecer um bom vínculo logo no início da aula.

\footnotetext{
${ }^{60}$ Informação fornecida em aula, 22/05/08, no Instituto Superior de Educação Pró-Saber (ISEPS)
} 


\title{
4.6.1.3 - A entrada e a saída da aula, do semestre, do ano
}

Observamos os modos de se relacionarem, professores e alunos. Estes se dirigiam aos professores pelos nomes ou apelidos, como por exemplo: Ritinha, Aninha, independentemente de serem professores, funcionários, alunos ou pais.

Uma das professoras comentou que achava que os alunos dessa escola eram frios, mas poderíamos considerar o mesmo dos professores que, na maioria das vezes, entravam e saíam da sala sem a menor menção de um cumprimento. . Vejamos alguns exemplos:

\begin{abstract}
A professora entrou e falou: "Vamos pegar a folhinha que eu falei que iríamos usar no $1^{\circ}$ semestre”. (Essa professora falava manso), e ficou conversando na sua mesa com uma aluna de outra turma, que trouxe seu material da outra aula. Não fez menção às férias dos alunos. Terminada a aula ninguém se despediu e nem arrumou a sala.
\end{abstract}

Homero, um de nossos alunos do estudo de caso, diz que gostaria que a professora lhe dissesse: "Olá, Homero tudo bem?".

\begin{abstract}
A professora combinou com a turma para deixar a sala limpa. Uma aluna respondeu corretamente a uma pergunta feita pela professora e esta lhe disse: "J. hoje está mandando muito bem”, ao que a menina respondeu: "Hoje não, sempre”, demonstrando como gostaria de ser reconhecida.
\end{abstract}

A professora disse a uma aluna: "T., sonhei com você! Até no sonho, credo!”

Miriam gostaria que o professor comentasse quando ela fizesse uma prova e conseguisse uma nota boa, demonstrando como desejaria fazer parte do imaginário do professor, mas ocupando um lugar de carinho e atenção.

Os alunos, quando acertavam, ficavam felicíssimos: - "Caraca, sou muito boa!"

Uma das práticas recorrentes dos professores, conforme já observamos, era entrar e sair da sala de aula sem cumprimentar os alunos, sem perguntar de seu desempenho nas provas, ou mesmo das férias, quando retornavam para a escola. Não queremos dizer com isso que fosse uma atitude malcriada ou deseducada. Simplesmente não havia essa preocupação. Parecia que os professores se sentiam como se já estivessem estado desde sempre naquela sala de aula, uma vez que agiam como se dessem bom-dia no início do ano e só se despedissem no final.

Não se pode esquecer, no entanto, que o trabalho desenvolvido com os alunos visa propiciar sua formação, e o fato de cumprimentá-los na entrada e na saída, ou pela tarefa cumprida, pode se constituir em uma forma de reconhecimento, demonstrar sua valorização, o que permite que o aluno possa construir uma auto-imagem positiva de si. 


\subsubsection{4 - A ironia}

Em algumas situações, observamos que havia nos diálogos expressões bastante irônicas usadas pelos professores com os alunos. Não havia exatamente a conotação de ser uma figura de linguagem, usada como forma de dizer o contrário do que se quer dar a entender, mas observávamos que algumas palavras ou expressões eram usadas em tom sarcástico, como se a intenção fosse fazer uma zombaria. Essas expressões eram utilizadas ao bel prazer do professor e diante de todos os alunos. Apresentamos, a seguir, alguns exemplos de comentários que consideramos jocosos, para melhor compreensão do que pretendemos dizer:

Chamou a atenção de uma aluna e logo começou a escrever o exercício no quadro. Em seguida, com uma voz firme, dirigiu-se para essa aluna: "Estudou? Muito? De verdade? Quero ver!", duvidando do que a aluna tinha dito.

Pediu que os alunos tivessem à mão sua folha de exercícios, lápis, borracha e iluminador, e começou a correção do exercício do livro didático. Notou um aluno no fundo da sala, que, segundo ela, não era costumeiro nas suas aulas, e disse: "Ótimo! Muito bom! Melhor do que nada!".

A professora explicou a prova e, quando algum aluno pedia esclarecimento sobre a prova, ela respondia de modo irônico: "O nome? Lógico, meu amor, que é o seu nome. Não vai ser o nome do seu vizinho!". Outro aluno perguntou a mesma coisa, $e$ ela respondeu com o mesmo tom irônico.

Um aluno comentou ter ido de prancha "lá nas ilhas Cagarras", e a professora retrucou: "Ah! Tá bom" (com ironia).

A professora chamou a atenção, pediu aos alunos que trouxessem a avaliação assinada e corrigida, dizendo: "É uma pena que a professora dê oportunidade para corrigir", em tom irônico, assinalando que os alunos não estavam aproveitando a boa vontade da professora em corrigir a prova novamente e, desse modo, os alunos poderem aprender com seus erros.

Não teria dever para casa. Brincou com os alunos: "Quem quer?" Vários alunos levantaram a mão, e ela diz: "não vou dar". (Ironia ou brincadeira?!)

A professora perguntou: "Alguém trouxe o teste assinado? Não, claro! Esqueceu, não assinou", em tom de gozação.

Dois alunos voltaram da diretoria, entraram em silêncio, e a professora disse com ironia: "Com licença para a professora".

A professora chamou a atenção de uma aluna: "Alô! Hoje é segunda-feira. Bom dia!".

Fechou a porta e disse: "Só para ter certeza que o barulho é daqui mesmo", usando de ironia para constatar o que ela já sabia, isto é, que o barulho era dentro da sala de aula.

- "R., para com sua cadeira!Vou pedir para a Irmã superiora só colocar cadeira de balanço.R., quando eu não estiver te atrapalhando você me avisa"! Com ironia. "M. e N. não sei nem o nome, porque elas estão sempre tão juntas!". 
Uma aluna parecia não compreender o que estava acontecendo, e a professora interveio brava, usando de mais ironia: "É sobre alguma coisa que esteja acontecendo no Brasil, no Brasil".

A cultura escolar designa os conhecimentos que são importantes de serem ensinados e as condutas que serão inculcadas através de um conjunto de práticas que são transmitidas pelos educadores. O uso da ironia seria uma estratégia paradoxal, uma vez que contradiz a intenção de formar o aluno com base no respeito mútuo das relações.

A psicanalista Alice Miller (1983) analisa os efeitos negativos causados pelo desprezo, que pode estar contido no uso irônico das palavras, além do fato de que, segundo ela, "a criança ressente a necessidade fundamental de ser levada a sério" (1986: 18).

Adler (1933/1991), no mesmo sentido, analisa os malefícios causados pelo desprezo e humilhação que levam a um sentimento de inferioridade. "Zombar das crianças, rir, criticá-la, dar outras crianças como exemplo, compromete o contato social e pode determinar uma atitude fechada sobre si, a timidez ou um pesado sentimento de inferioridade" (1933/1991:163 In: La Taille, 2002:71).

\subsubsection{5 - A retaliação ou queremos atenção}

Durante uma conversa, uma das professoras observadas trouxe uma reflexão sobre o sentido do processo educativo e se perguntou qual seria a mágica da sala de aula. Contou todas as suas iniciativas para que os alunos se interessassem pela aula, mas que observava que estes trabalhavam resistindo e reagindo às aulas. Ela relatou que primeiro tentou com música, mas que os alunos queriam Funk, ao que ela respondeu: "Vocês não gostaram da minha música e eu não gosto da de vocês". Perderam o direito de usar a sala de música, ou seja, , a professora se utilizou do que Piaget (1994) chama de justiça retributiva, embora no seu sentido menos evoluído, e que é própria da criança quando está desenvolvendo a moral da reciprocidade. No entanto, quando se trata de uma relação entre adulto e criança, fundamentalmente desigual, não é possível recorrer a uma relação de reciprocidade (do tipo toma lá, dá cá), uma vez que os níveis de responsabilidade não podem ser os mesmos, conforme Hannah Arendt bem assinalou, em seu artigo A crise de educação (1954; 2007).

Essa professora tinha uma fala baixa, suave, e alguns alunos chegavam a imitar seu jeito de falar. Em uma situação observada ela perguntou a uma aluna qual era o problema 
(por ela estar falando junto com a professora), ao que a aluna retrucou: "Ela que falou comigo e eu que tenho problema?", em uma atitude de enfrentamento à pessoa que tinha autoridade como professor investido pela escola.

\title{
Segundo Postic :
}

\begin{abstract}
"Não esqueçamos que se deve ter em conta o aspecto verbal da comunicação, que compreende a informação e a maneira de apresentar a informação e também os aspectos não-verbais da comunicação, porque certas mímicas, certos sinais gestuais são os indicadores de um estado, os índices de uma intencionalidade. Estas formas não-verbais de expressão no docente, o sorriso, o olhar, o franzir do sobrolho, o trejeito, os movimentos da cabeça, que aprovam ou desaprovam, os gestos da mão e dos dedos que designam os alunos e os convidam a se exprimir, as posturas corporais que indicam surpresa, a expectativa, o interesse, a decepção, etc., são espontaneamente decodificadas pelos alunos em sinais positivos, negativos ou neutros" (POSTIC, 2007: 138).
\end{abstract}

Outra professora falava sobre um livro com a turma e comentou com eles que achava que a classe média lia mais do que eles, ao que um aluno logo retrucou, atentando com propriedade para um fator essencial: "Leem porque têm dinheiro e podem comprar".

Em uma ocasião de muita tensão em sala de aula, a professora exclamou: "Meu Deus do céu!", e fez um gesto para um aluno mudar de cadeira. Ele relutou, mas foi. Uma aluna exclamou: "falta meia hora ainda!" (para acabar a aula). A professora respondeu: "vocês estão pagando a escola, não estão? Vocês estão pagando essa aula, não estão? E o que vocês estão fazendo? Jogando fora!" Sentou em sua cadeira e disse: "Quando vocês quiserem aula vocês falem", ao mesmo tempo em que pôs um aluno para fora da sala: -"Você está atrapalhando bastante, está surdo?". - "Eu estou esperando para poder fazer o exercício”. Nessa aula alguns alunos modificaram completamente seu comportamento diante dessa professora. Uma das alunas deu uns gritos para chamar alguém na sala e, mesmo quando a professora a reprimiu, ela continuou: "Está surdo? tô chamando!", da mesma forma que a professora tinha falado anteriormente, mostrando como aquilo a tinha afetado. Parecia que os alunos queriam chamar sua atenção a qualquer custo.

Uma menina falou: "Não sei nenhum pronome, vou chutar". Essa menina ficou indócil, mudou seu comportamento nessa aula, ficou diferente das duas primeiras aulas. Parecia querer chamar a atenção da professora, demonstrando sua insatisfação com o modo com que a professora se dirigia aos alunos. 
Outro aluno, que chegou e demorou a entrar em sala, foi repreendido pela professora, ao que respondeu de modo irreverente: "Eu tava no banheiro, tava mijando".

Apesar do barulho, as professoras não gritam ou berram com a turma. Chegam a levantar a voz, mas dificilmente na base do grito. Uma das alunas falou agressiva com a professora, e esta corrigiu: "Você não pode falar comigo assim, você está na sala de aula, requer outra postura".

Postic (2007) assinala que o grupo em uma sala de aula é um micro-sistema social, e o estudo sistemático das interações permite dois tipos de investigação:

- nível operatório (ou manifesto): problemas do docente, do aluno, respostas do aluno, intervenções espontâneas, etc.

- nível latente: referenciado pelas expressões afetivas (inquietação, interesse, desinteresse, agressividade, afetuosidade).

Nessa aula também surgiram outros pequenos diálogos entre os alunos e a professora, que dão a dimensão das tensões vividas na sala por professores e alunos:

Aluno 1 para aluno 2: Pô, como você é burro...

Prof.: Burro é um animal, portanto não pode frequentar a escola, portanto não tem na sala de aula.

Aluno 2 para a prof. (para ir a outra sala e entregar um material à professora da aula anterior) : Posso ir na L. entregar isso?

Aluna 3: Já foi, ela vai embora na hora do recreio.

Aluno 4: Foi para casa dormir.

Prof.: Guarde para si seus comentários, pode apostar que foi para outra escola, mas se foi dormir nada mais justo. Hoje você engoliu uma rádio-vitrola, estou perdendo a minha paciência.

Prof. repreendeu um aluno que colocava a mochila nas costas, em sinal de partida: Botar mochila enquanto estou na sala é falta de respeito! Está a fim de fazer graça?

Outro aluno: Bota melancia na cabeça. 
Prof. repreendeu uma aluna que mascava chiclete: Se conseguir ficar com o chiclete sem mascar nem vou pedir que cuspa!

Aluna: Como sou importante!

O que se passa com esses alunos que trabalham com algumas professoras e não com outras?

Durante uma observação em sala de aula imperava uma situação de mau comportamento dos alunos somado à bagunça. A professora exigia silêncio, embora sua aula fosse pouco atrativa e não oferecesse muito conteúdo, e os alunos se movimentando, mudando de lugar sem qualquer explicação. Essa professora, em particular, tinha muita dificuldade para ser obedecida, algumas vezes conseguia graças às ameaças. A aluna briguenta se pegava com o colega, os outros alunos ficavam rindo... A professora e a aluna tiveram o seguinte diálogo depois de uma repreensão da professora:

Professora: Você é aluna e eu sou professora. Não tem que responder. Falta de respeito.

Aluna: Você não me respeita.

Professora: Falta de educação.

Aluna: Minha mãe me deu educação, sim!

Professora: Ei!

E encerrou a conversa.

Dubet (1997) levantou a hipótese de que uma efetiva imposição de limites (ao contrário do que observamos acima) pode dar aos alunos um sentimento de segurança, por poderem contar com regras claras, e que nem tudo seria permitido. $\mathrm{O}$ espaço escolar deve ser de cidadania escolar, com regras e obrigações para alunos e professores.

Para Philippe Jeammet (2005), a adolescência é o espelho da sociedade. O jovem vive um momento paradoxal de sua vida, pois tem uma grande dificuldade de pedir ajuda por sentir que o outro vai exercer um "poder" sobre ele, sobretudo por sentir sua dependência do outro, ao mesmo tempo que quer obrigar o outro, nesse caso o adulto, a decifrar sua linguagem através dos seus atos e, desse modo, inverter a relação de dependência.

Ao toque do sinal que avisa que a aula tinha terminado, todos dão vivas, até a professora.

Para Piaget (1994), as relações de cooperação baseadas no "respeito mútuo, na troca de pontos de vista, no reconhecimento e respeito das diferenças - são aquelas que promovem desenvolvimento moral" (PIAGET, 1994:15). Uma relação raramente observada em sala de 
aula, a despeito dos propósitos da escola de promover uma educação de qualidade, na qual se inclui a formação ética dos alunos.

\section{7 - Reflexões do professor}

No Conselho de Classe uma professora desabafou com os seus pares a angústia que sentia pela falta de tempo para pensar na sua função de professora, no seu papel de mãe e de filha, ao mesmo tempo em que se indagava sobre o que a escola deveria propor, sobre o que seria educar nos tempos atuais. Constatou a transformação que houve na sociedade, pois para ela, vive-se uma cultura de morte, em que o ser humano passou de "penso logo existo" para "mato logo existo".

Outra professora acreditava que a situação atual da realidade do professor era um obstáculo para se desenvolver um bom trabalho, o que denominou: o grande calcanhar de Aquiles, pois o professor, ao trabalhar em dois ou três colégios, não teria tempo para pensar em seus alunos, o que causaria muitas vezes uma avaliação injusta. Exemplificou, relatando a sua terça-feira, quando trabalhava cinco tempos pela manhã, comia rapidamente um sanduíche dentro do carro, preocupada, por exemplo, com a aluna Miriam, mas no caminho já tinha se esquecido dela por começar a pensar nas aulas que daria no período da tarde. Tinha notado que a Miriam estava muito triste, muito quieta naquele dia, ou o Homero, que normalmente era mais agitado, estava tão quieto, mas ela não teve oportunidade para conversar com ele, de chegar até ele para saber o que aconteceu e aquilo passou, outros assuntos se tornaram prioritários. Ponderou que se fosse uma professora com tempo perceberia do mesmo modo, mas poderia fazer algo porque teria acesso a esses alunos, e até mesmo, poderia conhecer os pais, e concluiu "um dos motivos da dificuldade dos professores são as famílias deixarem seu papel de educadores para a escola". Quer dizer, embora tenha chegado próximo do reconhecimento de um dos problemas cruciais da educação hoje, que é a falta de tempo para a elaboração do vivido em sala de aula e, consequentemente a falta de tempo para preparar adequadamente as aulas, tomando em consideração a experiência de um contato vivo com os alunos, a professora termina concluindo que o problema é das famílias que lhes transfere o papel de pais de seus filhos.

Para ela, a escola teria que ter avançado e evoluído mais, porque a escola "não prepara para a vida, ela é vida. É o começo da vida na sociedade. Os alunos saem daquele mundinho com pais, irmãos, e a primeira vivência que têm é na escola”. 
Winnicott sugere que a escola "seja uma ampliação da família 'para cima', ao dar continuidade ao trabalho da mãe, suplementando e prolongando o que o lar iniciou" (Winnicott, In FRELLER, 2001:222 - grifo do autor).

A professora não considerava fundamental que as camadas populares aprendessem outra língua, mas comentou que ao perguntar aos alunos o motivo de quererem aprender inglês, eles respondem: "para eu conseguir um bom emprego". Para ela, poderiam existir bons empregos que não exigissem o conhecimento de outra língua, mas julgava que ter uma língua estrangeira fazia diferença, atualmente, por ser um diferencial, tendo em vista a globalização, e pela confiança adquirida pelo aluno por ter esse conhecimento.

Quanto à metodologia, os professores constataram que não modificaram a sua didática em sala de aula, apesar da chegada da nova clientela das camadas populares. Até insistiam e buscavam ser o mesmo professor, considerando que assim não faziam "diferença" entre os alunos de classe média e o das classes populares, e concluíram: tem que ser a mesma professora para esse aluno, independentemente de onde more, porque todo mundo tem direito à mesma oportunidade de ter acesso às informações. Ocorre que, desse modo, cometiam outro tipo de injustiça, conforme assinalou Dubet (2004), a da "meritocracia" em uma sociedade em que as oportunidades são desiguais.

No entanto sabem que "sempre é diferente porque na vida e na profissão se evolui". Uma professora citou como exemplo a metodologia que usava em 1985 e a atual, totalmente diferente, mas ressaltou que não foi porque mudou a classe, e sim pelo fato de a educação ter mudado de uma maneira geral. "O objetivo é o mesmo, mas a forma de se trabalhar esse objetivo é diferente. Essas mudanças acontecem decorrentes das provas do vestibular. Então, atualmente, se trabalha mais leitura de interpretação de texto e a gramática mais vinculada ao texto".

Já os professores de Educação Física ressaltaram que o professor que buscasse trabalhar a partir da experiência dos alunos teria mais facilidade na sua disciplina do que, por exemplo, com História e Geografia, porque

\footnotetext{
"as outras disciplinas vão lidar com alunos que vêm de experiências e vivências diferentes, mas o mesmo não se dá no esporte, pois a vivência vai ser igual, as regras colocam todos no mesmo patamar. Quando se propõe a fazer uma coisa todos saem do mesmo lugar e vão chegar, dependendo aí do esforço de cada um. Se ele se esforçar muito, ele vai ser um expoente dentro daquilo, mas ele tem a mesma chance igualzinha”.
} 
Esses professores demonstram levar em consideração o que a criança sabe, o que traz , para que o aluno seja um modelo e os outros achem interessante conviver com um colega com uma técnica mais avançada. Mas não consideraram que uma questão essencial aproximava o sentido de suas aulas do que pudesse nortear as aulas de história e Geografia: não apenas o desempenho do aluno, mas seus usos e costumes, suas origens e sua própria história.

Fizeram questão de mencionar o espaço amplo do Stella Maris, assim como os recursos disponibilizados, o que facilita o trabalho: "Quando você tem o espaço e os recursos materiais você consegue fazer um trabalho muito mais ao encontro do interesse deles, porque quando o grupo é maior você divide os grupos, a dinâmica fica muito facilitada".

Já outra professora disse que utilizava o método tradicional em suas aulas, isto é, quadro de giz e exposição por achar que os alunos "estão mais acostumados". E que o melhor jeito para eles se comportarem era a turma ficar sem parte do recreio. Concordou que agia por reciprocidade, como se fosse uma relação de equivalência: "Era olho por olho".

Dubet, no decorrer do seu artigo sobre sua prática como professor de adolescentes, acrescentou que se sentiu aliviado ao poder comentar com os outros professores sobre a sua atuação em sala de aula e suas dificuldades, e justificou: "Talvez eu pudesse dizer que sentia dificuldades porque meu status social me permitia dizê-lo sem ter o sentimento de vergonha. Pode ser mais duro para um professor iniciante" (DUBET, 1997: 224). Este foi o caso de uma professora que não conseguiu suportar a pressão e terminou por se demitir no meio do segundo semestre, saindo frustrada por não ter conseguido atender às suas expectativas, nem às dos alunos e nem às da escola.

Dubet (1997) assinalou que Claude Allègre ${ }^{61}$ dizia ser preciso que os alunos aprendessem poucas coisas, mas que as aprendessem realmente porque acreditava que o que os fazia progredir era superar dificuldades e não o mero acúmulo de conhecimento. Para Dubet, não fazia sentido manter programas feitos para uma pequena elite social burguesa. Se a classe burguesa perdesse um pouco de tempo na escola não seria muito grave, mas era uma violência para as camadas populares! Ele sustenta que a situação escolar deve fazer sentido para o aluno, principalmente para os estabelecimentos populares porque para esses alunos a

\footnotetext{
${ }^{61}$ Dirigiu o ensino superior na França durante um longo período.
} 
escola não é uma coisa normal como pode ocorrer em outras classes sociais que têm seu padrão de vida voltado para a formação escolar.

Ele reitera que possa existir uma democracia escolar, mas que para isso é necessário a criação de regras de vida em grupo definidas, aplicadas e recíprocas. Sem elas a escola se esvazia de sentido, porque o diploma já não é garantia para o acesso social, e se a instituição estiver preocupada com isso e não com o sujeito "entendedor" do mundo, vai mesmo ficar esvaziada.

Observamos que os professores, na hora de falar sobre os alunos no Conselho de Classe, se detêm nos problemas psicológicos e pessoais destes, mas na hora de trabalhar conteúdos falam sobre as suas lacunas, sem conseguir identificar os problemas coletivos gerados por um modelo de ensino e por uma concepção de cultura distante do universo dos alunos.

A escola pesquisada proporciona várias instâncias de apoio à prática docente dos seus professores como sala de reuniões, lanche coletivo diário com encontro dos professores, quatro conselhos de classe feitos anualmente, além de orientação pedagógica e educacional. $\mathrm{O}$ professor e a professora podem encontrar ambientes favoráveis que incitem o questionamento de sua prática e aproveitá-los para discutir com seus pares a busca de soluções para os diversos problemas diagnosticados. Mas para tanto é preciso que os professores aprendam a lidar com as diferenças. Não é esperar e querer criar uma escola ideal, um aluno ideal, uma família e uma equipe ideais e, sim, uma escola democrática, em que se construa um processo coletivo de educação dos alunos, com suas especificidades e demandas. 


\section{Considerações finais}

\section{DA ESCOLA QUE ENSINA A ESCOLA QUE APRENDE}

"A escola que aprende caracteriza-se pelo trabalho em equipe, pela colaboração e por um elevado apreço pela mudança e pela inovação como processos normais e necessários para o desenvolvimento e a adaptação da escola às mudanças que afetam o entorno social em que está inserida. Seus membros têm disposição favorável para enfrentar desafios, capacidade empreendedora; eles valorizam a autonomia, o trabalho colaborativo e a responsabilidade profissional como formas de trabalho cotidiano e permanente do educador para melhorar a eficiência dos processos de ensinoaprendizagem".

Monterola Pacheco e Astudillo Castro (2002) ${ }^{62}$

É difícil terminar um trabalho que nos acompanhou, e pelo qual fomos acompanhados durante quatro anos, no mínimo. Logo que iniciamos essa pesquisa a diretora nos contou sua expectativa de que houvesse um intercâmbio entre a dissertação e o trabalho realizado na escola. A partir dessa observação gostaríamos que as conclusões apresentadas fossem vistas como um ponto de reflexão, e não como um ponto final.

Dissemos nesta dissertação que a escola se abriu para o novo ao assumir como alunos os habitantes das favelas circunvizinhas à escola. Ela não só se abriu para as comunidades do Vidigal e Chácara do Céu, mas se propôs a ser fonte de pesquisa, deixando-se ser observada, vista e analisada, sem colocar qualquer obstáculo. Realizamos este trabalho de pesquisa, cientes de que este pode ser visto como uma crítica, mas acreditamos que, ao acolher o olhar do outro, a Direção da escola espera uma contribuição para dar prosseguimento à sua tarefa educativa. Também gostaríamos de destacar que essa pesquisa, ao centrar sua atenção nas $5^{\mathrm{a}}$ e $6^{\mathrm{a}}$ séries, teve sua análise restrita a este grupo de alunos do Centro Popular Stella Maris.

Aprendemos com a Antropologia, nas palavras de Machado (2005-2006) ${ }^{63}$, a dificuldade do desafio "de se interpretar vestígios materiais que são resultados de processos dinâmicos de manufatura, utilizações, reciclagens e descartes num contexto sistêmico. Tal inserção sistêmica lhe confere uma dupla posição de significado e significante nesse universo, ao mesmo tempo refletindo aspectos fundamentais da sociedade que o produziu e produzindo novos significados nessa mesma sociedade" (MACHADO, 2006:87\}.

\footnotetext{
${ }^{62}$ De una escuela que enseña a una escuela que aprende: el aprendizaje de los buscadores, boletin de investigacion educacional, vol.17:82-100, 2002.

${ }^{63}$ MACHADO, J.S. O potencial interpretativo das análises tecnológicas: um exemplo amazônico. Rev. do Museu de Arqueologia e Etnologia, São Paulo, 15-16: 87-111, 2005-2006.
} 
Fazendo uma transposição do contexto antropológico para o educacional, constatamos que o levantamento da pesquisa de campo converge nessa mesma direção, pois os vestígios materiais podem ser os dados com que trabalhamos no levantamento da pesquisa de campo. Ora, esses dados podem ser as atividades em sala de aula que não deixam de ser os resultados dos processos dinâmicos de planejamento das aulas, das utilizações de abordagens teóricas escolhidas pelos professores e de acordo com a orientação da escola, das "reciclagens" de aulas anteriormente formuladas e dadas dependendo da experiência do professor, e dos "descartes" que o professor faz no seu planejamento diante de uma determinada turma de alunos. Essa inserção sistêmica que ocorre com a escola, ela mesma um dos vários subsistemas da sociedade, confere-lhe uma dupla posição de significado e significante nesse universo, pois ao mesmo tempo em que reflete aspectos fundamentais da sociedade que a produziu, ela própria está permanentemente produzindo novos significados nessa mesma sociedade.

Uma diretora e uma coordenadora em seu depoimento comentaram que neste grupo social aparece muito déficit de atenção e dificuldades na apreensão da matéria por parte dos alunos. Algumas das explicações dadas ao problema são as seguintes: o fato de as crianças não terem pais, ou quando têm, estes não têm instrução, são por vezes subnutridos, e moram em um contexto de muita violência, situado em uma cidade socialmente 'difícil', isto é, caracterizada, sobretudo, pelo abandono do Estado (o tráfico de drogas ocorre às claras, as ruas são perigosas, a violência é endêmica, os jovens não dispõem de espaços de lazer). Mas essa pode ser uma forma preconceituosa de olhar as crianças de baixa renda, atribuindo-lhes uma série de carências, além de culpá-los por sua origem social, sem atribuir responsabilidade alguma à própria instituição escolar. Isto pode se dar não porque se afirme que a defasagem cognitiva seja inerente à condição econômica, pois tal defasagem também aparece em outros contextos. Perceber e constatar problemas nos alunos sem nenhuma atuação no sentido de procurar enfrentá-los causa desgaste para o próprio professor, uma vez que mobiliza sua impotência diante de um quadro, como dos alunos Homero, Miriam e Nara, se nada for efetivado. Ou fazendo-o de modo ineficaz: no caso de Homero, tirando-o do projeto que ele adora, para fazer recuperação; Miriam embora seja considerada uma aluna em defasagem quanto ao conhecimento exigido pela escola, não ficará retida com a justificativa de que ela não possui "raciocínio lógico-matemático", segundo uma das professoras; Nara precisa de aula de apoio mas não vem e ninguém luta por ela. $O$ professor percebe que sua turma não sabe responder onde mora na cidade do Rio de Janeiro; isso serve como denúncia mas nada 
acontece. Sabemos que o professor não dará conta sozinho desses alunos. É um trabalho de equipe que poderá oferecer sustentação e permitir ações educativas para auxiliar esses alunos. Caso contrário, quem pagará a conta mais uma vez serão os pais. A escola, na figura dos professores e da equipe, se eximirá do problema e agirá como os pais da classe média que se afastaram dessa escola, quando foi “invadida” pela favela. Seus habitantes ainda são vistos como um ser menor, inferior, desajustado ou incapaz, que, segundo a antiga clientela, prejudicaria o padrão de qualidade dessa escola, fruto de uma visão estereotipada e preconceituosa ainda profundamente arraigada na mentalidade das classes média e alta.

Segundo as pesquisas feitas por Maria Apparecida Mamede Neves no NOAP da PUCRJ, pode-se depreender a idéia de que a escola, pobre ou rica, conforme se encontra constituída, tem uma parcela muito grande de responsabilidade, quando não se revela adequada como elemento facilitador da construção dos esquemas operatórios. Porém, não há dúvidas de que os danos cognitivos impostos às camadas populares são maiores, na medida em que não se oferecem recursos para minimizá-los, e que estes danos são vistos, por muitos, como consequência inerente ao contexto dessa população.

Não estamos aqui para dizer que é a criança que fracassa por causa do seu contexto, da falta de nutrição, de práticas educadoras preconceituosas e discriminadoras apoiadas em diferentes discursos que circulam acerca das classes populares. O que queremos é defender uma nova abordagem de ensino para atender a essa criança. Acreditamos que existe um espaço de ação no âmbito de cada escola, que acontece também pela vontade política e pedagógica de todos os atores ali envolvidos. Isso supõe a identificação das dificuldades e obstáculos, evidentemente, apresentados pelas crianças das camadas populares, que anteriormente estariam talvez até mesmo excluídas do processo de escolarização. Mas nossa abordagem supõe também a identificação de modos criativos e estratégias alternativas para lidar com esses alunos com dificuldade de aprendizagem, observando, 


\section{sistematizando e registrando práticas de ensino bem-sucedidas; que poderão - no limite - ser socializadas pelo coletivo dos professores.}

A posição assumida pela escola, ao optar por atender as camadas populares, deixa evidente sua crença na capacidade de aprendizagem de seus alunos e também na capacidade profissional dos professores. Estes, no entanto, são convocados a cumprir um conjunto de normas que definem os conhecimentos a ensinar, as condutas a inculcar e o conjunto de práticas que permitem a transmissão desses conhecimentos e a incorporação desses comportamentos, normas e práticas da cultura escolar. Tudo isso cria um habitus para as práticas escolares que dificulta a incorporação de toda e qualquer inovação. No entanto, as inovações propostas pela direção levaram-nos a acreditar que a escola estava determinada a possibilitar e propiciar o processo de construção do conhecimento dos seus alunos.

A construção arquitetônica favorece o processo educacional na medida em que oferece espaço para que isso ocorra. São $6.000 \mathrm{~m}^{2}$ distribuídos em 5 andares de salas de aula, espaço que permite manter a Educação Infantil com salas de aula e recreação em local restrito; o Ensino Fundamental com salas de aula separadas do $1^{\circ}$ e o $2^{\circ}$ segmentos do Ensino Fundamental, em blocos distintos, preservando a segurança dos alunos, sem restringir a realização de atividades físicas como nos jogos de bola, queimada, futebol, vôlei, etc., além de permitir que se expandam com segurança nos corredores e no pátio da escola.

Há conservação permanente da escola, incluindo a iluminação e ventilação das salas. Essas são de tamanho adequado para receber as turmas, pois são amplas, contém lousas, mesas e cadeiras bem conservadas, além de armários, murais e livros em excelente estado (bem diferente, aliás, daquelas observadas em pesquisa de Amaral, 2007 em uma escola pública de São Paulo).

Contam com o mesmo quadro de docentes, a maioria da época em que a escola atendia os alunos de classe média e média alta, mas muitos deles também vindos com experiência de escola pública, como se pôde depreender de seus depoimentos.

Do mesmo modo como observara Tepedino (2007b), constatamos, ao longo do trabalho, que a mudança de público não afetou a prática pedagógica da escola como um todo: “No Ensino Fundamental, além da maior resistência dos agentes em alterar o currículo e a avaliação - o que exigiria introduzir modificações no regimento interno da escola - notam-se 
também, um trânsito maior de professores/as e uma menor sensibilidade ao tema da diversidade cultural" (Tepedino, 2007:116).

Temos que levar em conta que o projeto implantado é muito recente, com início em 2000, e ainda sem que uma turma com entrada na Educação infantil tenha se formado. Não queremos dizer que, por ser um projeto "jovem” ainda, não estejam preparados para receber as crianças, ou que ela esteja se esquivando de sua responsabilidade com os alunos e seus compromissos, mas apontar que a instituição teve pouco tempo para amadurecer a construção desse projeto.

Após essas ressalvas, pretendemos percorrer o desenvolvimento deste trabalho e, ao mesmo tempo, refletir sobre algumas questões a serem destacadas.

[...] Falamos de homens concretos, abordados em suas condições concretas de existência. ... Sua condição de seres vivos e, em consequiência, de sujeitos de necessidades em permanente intercâmbio com o meio (Pichon-Rivière, 1998:IX) ${ }^{64}$.

As mudanças do cotidiano e o redirecionamento do projeto pedagógico do Centro Popular Stella Maris, uma instituição de ensino particular de tipo confessional, originalmente voltada às camadas médias da população carioca, para atender as populações faveladas da Chácara do Céu e do Vidigal, representam, sem sombra de dúvida, uma importante e bela experiência acadêmica que nos evidencia a relevância do projeto.

Consideramos interessante o fato de termos começado nossos estudos com a pesquisa de Maria Helena Souza Patto. Não fomos levadas a assumir o trabalho da escola com alunos das camadas populares como de antemão em uma situação de fracasso escolar, apesar de sabermos que a contribuição de Patto seja sobre esse tema. No entanto, nosso objetivo foi nos defrontarmos com essa problemática, e verificar como seria encaminhado um trabalho que especificamente lida com crianças pertencentes aos segmentos mais empobrecidos das classes subalternas, onde o fracasso escolar tem sido tão comum e, muitas vezes, até "mascarado" pela "progressão continuada". Os estudos de Patto nos possibilitaram um olhar mais perspicaz que iluminou os problemas surgidos ao longo da pesquisa de campo.

A prática pedagógica pressupõe uma adesão a certos valores, comportamentos e ethos $^{65}$ das famílias dos alunos que buscam uma determinada escola. Buscamos a teoria

64 Pichon-Rivière, Enrique. Psicologia da vida cotidiana. São Paulo: Martins Fontes, 1998, p. IX) 
sociológica de Bourdieu, que nos idos dos anos 60 mostrou que a trajetória escolar dependeria de certos pré-requisitos que não comporiam o universo cultural das classes não dominantes. Fomos além da nossa 'ingenuidade' e observamos a estruturação da sociedade de outro ponto de vista. Foi uma decisão difícil porque a leitura de Bourdieu, muitas vezes, suscitou irritação pela nitidez de sua análise, pela exatidão com que o autor aponta e desfia o tecido da experiência escolar ao desvelar o processo educativo atrelado ao modelo da classe dominante.

Pouco a pouco, Bourdieu explicita questões que ficam latentes na ação pedagógica, apontando os pontos de dominação em suas tentativas de 'ajustamento' das crianças das camadas populares à tarefa educativa, mostrando de forma visível a prática pedagógica que não efetiva ações capazes de promover essas aquisições. Na produção deste fracasso, assinala Patto, estão envolvidos aspectos estruturais e funcionais do sistema educacional, concepções de ensino e de trabalho e preconceitos e estereótipos sobre sua clientela mais pobre. Estes preconceitos, no entanto, longe de ser uma característica apenas dos educadores que se encontram nas escolas, estão disseminados na literatura educacional todas as vezes que se cristalizam como uma fatalidade as dificuldades de escolarização das crianças das classes populares.

No entanto, cabe ressaltar que não nos deparamos com famílias presas às necessidades e urgências da vida, que se recusaram a contribuir para o estabelecimento das redes internas de admoestações e incitações capazes de regular as estratégias cotidianas adequadas às exigências mais legítimas (escolares, culturais, sociais, dentre outras). Ao contrário, encontramos famílias que não se intimidam com a instituição escolar: ao terem oportunidade de escolher a instituição de ensino, ficou claro como investem na educação dos seus filhos.

Como havia dúvidas e questionamentos acerca dos processos e benefícios de uma escolarização realizada com marcada diferença de nível social e de valores culturais entre docentes e estudantes, pusemo-nos a tematizar a questão da cultura. Acreditávamos que definir cultura seria simples pelo fato de os professores serem unânimes em afirmar que os alunos vinham de uma cultura diferente. Ledo engano. O que pensávamos que fosse fácil, mostrou-se um vasto campo a ser investigado para esclarecer o que é cultura.

\footnotetext{
65 Ethos está sendo empregado como "sistema de valores implícitos e profundamente interiorizados, que contribui para definir, entre coisas, as atitudes face ao capital cultural e à instituição escolar" (BOURDIEU, 1998:42)..
} 
Nas entrevistas realizadas e mesmo em conversas com os professores, alguns destes se referiram à questão da educação, chegando mesmo a dizer que as crianças eram 'maleducadas'. Esses relatos nos soavam incoerentes ou mesmo distantes das entrevistas realizadas com as mães da comunidade e a observação feita em salas de aula das $5^{\mathrm{a}}$ e $6^{\mathrm{a}}$ séries do Ensino Fundamental. De um lado, observávamos que os alunos mostravam muita satisfação por frequentarem essa escola e a maioria tinha um bom comportamento; vez por outra, havia uma resposta que poderia se interpretada como malcriada, mas proporcionalmente à quantidade de alunos, essa resposta 'atravessada' era em número insignificante. Por outro lado, as mães também mostravam satisfação por terem seus filhos nessa escola. Muitos mostravam empenho em mantê-los nessa instituição, buscando aulas de reforço escolar para seus filhos, mostrando-se interessadas pelo cotidiano escolar, conversando com a diretora e professores. Enfim, revelando cuidado e valorização para com a escolarização dos filhos. No entanto, todo esse empenho era pouco notado pelas professoras, conforme observamos em seus francos depoimentos e entrevistas, quando falavam sobre a relação pedagógica.

Também aprofundamos nossos estudos sobre o trabalho em sala de aula e nos indagamos sobre o que seria, afinal, uma aula. Observávamos que a transmissão dos conhecimentos, ou melhor, a parte referente ao conteúdo da aula - aquilo que o professor prepara antes de ir para a sala de aula, o seu planejamento - não deixava claro qual era a atitude esperada dos alunos para que pudessem desenvolver os conhecimentos de sua disciplina. Foi essa dinâmica que se destacou e nos levou a pensar na questão da civilização escolar, na medida em que a ação pedagógica se apresentava como um processo que contemplava a dinâmica da sala de aula como tentativa de realizar a tarefa de converter as crianças e os jovens em 'alunos'.

Estamos tão pouco acostumados a lidar com a diferença que procuramos educar a todos do mesmo modo independentemente de ser uma voz feminina ou masculina, uma pessoa da classe dominante ou da classe dominada, pressupondo que se partíssemos de uma base comum, um mesmo patamar, ou um lugar comum, estaríamos oferecendo a mesma oportunidade para todos, sem fazer distinção de classes ou de gêneros.

Abordar o tema da diversidade cultural, ou melhor, clarificar a problemática das relações entre educação e cultura de maneira aprofundada, pareceu-nos indispensável para 
abordar questões fundamentais da educação, tais como: cultura, educação, cultura escolar, civilização escolar e mundialização.

A diversidade cultural e seus contrastes são apresentados aqui para aclarar uma distinção entre dois modos de pensar e focalizar um problema. Essas diferenças surgem num contexto social em que são 'desejáveis' padrões que tendem a assumir o ethos e a ótica de camadas sociais com mais capital cultural, ou seja, a cultura valorizada pela sociedade. Os capitais cultural, econômico, social, simbólico são confrontados e suscitam questões complexas, quando se pretende ouvir uma população marginalizada por uma sociedade preconceituosa, que supõe que um determinado segmento da sociedade pode servir de referência e determinar expectativas em relação às outras pessoas. Com base nisso, os professores justificam as dificuldades das crianças e de suas famílias, que são acusadas de não valorizar a escola. Nossas observações, enriquecidas pela pesquisa de Thin, permitem que nos aproximemos das lógicas socializadoras das camadas populares e as relacionassem à visão da escola.

As professoras relataram que seus alunos têm um vocabulário pobre e não sabem nomear-se e nem nomear objetos comuns; suas frases são curtas, monossilábicas e incompletas; sua sintaxe é confusa, o que dificulta a expressão e compreensão do seu pensamento lógico; segundo elas, comunicam-se muito mais através de uma linguagem nãoverbal. O desafio é a identificação dos obstáculos sociais e culturais à aprendizagem, para ser capaz de ajustar-se à realidade social.

Daniel Thin (2006) pesquisou as relações das famílias com as escolas e questionou a visão depreciativa do déficit educativo das famílias populares. Avançou sua pesquisa no sentido de investigar e aprofundar os conhecimentos sobre as relações das famílias populares com a escola e o processo de escolarização. Para a nossa realidade observada, foi relevante constatar que o estudo francês também apontava para uma outra lógica das práticas escolares das camadas populares, bem contextualizados no meio em que viviam. Apesar de essas idéias serem recentes na teoria educacional, fizeram sentido em nossa pesquisa e mostraram sua amplitude, pois um fenômeno constatado na França é, ao mesmo tempo, observado no Brasil.

A pesquisa de Thin considera a importância dos estudos de Bourdieu, "o capital cultural é certamente um indicador valioso quando se trata de classificar os sujeitos sociais e suas práticas culturais e educativas" (THIN, 2006:212), no entanto, avalia que este último 
deixou de fora questões centrais que envolvem as relações dos pais das camadas populares com seus filhos, que apesar de seus poucos recursos culturais e escolares, mantêm boas relações com a escola (talvez pouca se comparados às expectativas dos professores) como contribuição para a escolarização de seus filhos.

Todos os segmentos da sociedade contemporânea de maneira geral, e em particular, aliado ao observado em nossa pesquisa de campo, ressaltam a valorização da escola com a presença de um projeto de educação para os filhos, independentemente da classe social. A valorização da escola é universal, mas seu significado varia de classe social, encontrando-se na dependência de se vislumbrar algum futuro possível, a partir da escola, e de acontecimentos vividos na trajetória de um indivíduo, de um grupo familiar ou de uma classe social. O diploma escolar é visto de diferentes maneiras, dependendo da classe social. Para uns, aliado ao status econômico, o diploma é 'um a mais', mas não de todo necessário; já para outros, observa-se a prioridade de um título universitário, considerando que uma boa educação servirá de herança para os filhos. Estes últimos agem motivados não por um projeto, dispositivo tipicamente intelectual de antecipação consciente do futuro, mas imbuídos de uma visão pré-reflexiva acerca do futuro, envolvendo expectativas reduzidas de ascensão social, colocando, porém, muita expectativa no capital simbólico associado ao diploma, conforme se pode depreender de Bourdieu (1997), em A miséria do mundo.

Para alguns grupos das camadas populares, o significado da escolarização depende da entrada no mundo do trabalho que a escola tornará possível, pois seu mérito é visto segundo a dignidade que aquele confere ao indivíduo. O trabalho é visto com seriedade assim como a escolarização, que deve ser assumida com responsabilidade, pois é ela que conferirá um novo status ao indivíduo. Ser pobre, mas trabalhador, tem um significado simbólico, uma vez que qualifica socialmente a pessoa ${ }^{66}$.

Há evidente relação entre o capital escolar dos pais e a chance de sucesso escolar dos filhos. Pais mais escolarizados têm mais capital cultural, investem na escolarização dos filhos, e não é à toa que professores e coordenadores apontem a relevância da interação e da participação dos pais no processo educativo dos filhos. No entanto, consideramos que ainda há poucos estudos sobre o papel dos pais em relação à escola e ao empenho de seus filhos.

\footnotetext{
${ }^{66}$ No entanto, como afirma Paixão (2005), não é qualquer trabalho, como ela exemplifica em seu artigo sobre as representações que as catadoras de lixo têm sobre si mesmas.
} 
A importância prática de nossa pesquisa decorre da possibilidade de utilização do projeto realizado pelo Centro Popular Stella Maris para que outras escolas leigas ou confessionais considerem a possibilidade de contribuir de alguma forma com as camadas populares que não podem, em geral, pagar por serviços particulares. Raramente os estabelecimentos particulares (como também estabelecimentos escolares públicos) produzem saberes que contemplem a contribuição da iniciativa privada para o estabelecimento de políticas públicas no campo educacional.

A escola pública e obrigatória para todos é um fenômeno recente e visa oferecer condições de igualdade entre as pessoas. Desde o início da modernidade até os dias atuais, grande parte da população aprendeu a ler e escrever, obrigatoriamente e não por vontade própria. O educador português Rui Canário $(2003)^{67}$ considera que a construção da escola do futuro deverá ter como uma das suas finalidades fundamentais: "construir uma escola onde se aprenda pelo trabalho e não para o trabalho", na qual o aprender evolua da repetição de informação para a produção de saber.

Nesse mesmo sentido, os trabalhos de Boto assinalam que "a primeira característica da civilização escolar foi a radical transposição da criança para o aluno" (BOTO, 2007:41), proposição semelhante à de Monterola Pacheco e Astudillo Castro (2003), quando estes afirmaram que a escola erigiu, historicamente, como requisito prévio da aprendizagem, a transformação das crianças e dos jovens em alunos. Construir a escola do futuro supõe a adoção do procedimento inverso: transformar os alunos em pessoas. Só nessas condições a escola poderá assumir-se, para todos, como um lugar de acolhimento para a produção do saber e do intercâmbio cultural.

Desse modo aproximamo-nos do pensamento de Forquin para quem a cultura escolar é caracteristicamente seletiva no que concerne à cultura social, e a

[...] educação não transmite $a$ cultura, considerada como um patrimônio simbólico unitário e imperiosamente coerente. Nem sequer diremos que ela transmite fielmente uma cultura ou culturas: ela transmite, no máximo, algo da cultura, elementos de cultura, entre os quais não há forçosamente homogeneidade, que podem provir de fontes diversas, ser de épocas diferentes, obedecer a princípios de produção e lógicas de desenvolvimento heterogêneos e não recorrer aos mesmos procedimentos de legitimação. (Forquin, 1993:15).

\footnotetext{
${ }^{67}$ Entrevista concedida ao jornal Folha de São Paulo em 29/7/2003.
} 
Nossa investigação refletiu sobre o papel da escola nessa transmissão de cultura. Tecemos a relação da civilização como a arte de se tornar cidadão e traçamos um paralelo com o termo civilização escolar como sendo a arte de transformar uma criança em aluno. Como sustenta Boto (2007): "as práticas educativas no Ocidente desde a Renascença, têm uma clara intenção civilizadora. Seja para criar homogeneidades, seja para estabelecer distinções, a idéia de disciplina escolar instituiu-se mediante rituais específicos" (2007:37). Tal perspectiva mobiliza uma reflexão sobre o lugar civilizador ocupado pelas instituições escolares na produção de rituais e de formas de agir que lidam com o conhecimento, mas que também se reportam a maneiras de se comportar socialmente no mundo. Nesse sentido, a instituição escolar integraria o processo civilizador da sociedade, no sentido apontado por Norbert Elias.

As entrevistas com os pais das camadas populares demonstram que a expectativa que têm da escolarização dos filhos não está vinculada exclusivamente ao desempenho escolar dos mesmos. O objetivo central é a questão relativa à convivência social. Esperam que a escola promova comportamentos sociais adequados à vida em sociedade, como "saber se comportar em qualquer lugar", bem como a formação moral da criança, traduzido por conceitos, como: "ter bom caráter", "respeitar o outro" e "ser honesto". Além da instrução, da educação, da moralidade, a escola, segundo os pais, por ser confessional, auxiliaria os alunos a conhecerem os perigos e riscos que os rodeiam e a que estão expostos e os alertaria sobre a realidade do mundo em que vivem. Verifica-se, portanto, que a expectativa é a de que tais comportamentos possam também conduzir os estudantes para a fruição de bens culturais que, de algum modo, os integrem à vida social, tanto do ponto de vista pessoal quanto no âmbito profissional; mas principalmente no que diz respeito a viver com os outros.

Desse modo a escola se vê confirmada pelos pais como uma instância social produtora, não apenas de conhecimento, como também de cultura e civilização. Nessa direção, o ambiente escolar, além de possuir um universo próprio, específico, de apropriação cultural, mobiliza de uma maneira peculiar e privilegiada as referências civilizatórias de uma determinada sociedade.

Para nós, o ambiente escolar vai além desse caráter civilizatório pontual: a escola lida com um dado modelo cultural prévio e anteriormente prescritivo, baseada em uma determinada concepção de desenvolvimento humano e uma determinada concepção de história, que tende a pressupor que o futuro será melhor que o presente; e que este, por sua 
vez, é melhor do que o passado (como expusemos no capítulo 1). As gerações mais velhas, ao fazerem isso, conferem à instituição escolar um lugar privilegiado, ao produzir o que Norbert Elias nomeia como "processo civilizador, segundo o qual, por meio da escola, assegurar-se-ia um "bom comportamento uniforme" (Elias, 1994:91), o qual, por sua vez, determinaria expectativas e referências em relação às outras pessoas. $\mathrm{O}$ processo civilizador envolve, sem dúvida, alguma relação com o poder, mediante a intensificação da "pressão que as pessoas exercem reciprocamente umas sobre as outras" (Elias, 1994:93). E a escola seria protagonista desse território civilizador.

Sara Paín, a propósito da escola, considera que a especialização de conhecimentos bem como a migração para os centros urbanos criam a necessidade de educação que assegure a formação uniforme da nova geração. "Sobre essa base atua a escola, lugar de recorte social, onde a aprendizagem não se produz principalmente por impregnação, mas por uma ação dirigida, com uma graduação de fins e meios, explícita e elaborada” (Paín, 2008:15).

Ora a escola proclama um papel cuja função está impregnada de ambiguidades. Devido ao seu papel conservador, repressor e censor, poderia negar a capacidade pensante dos seus alunos, presos às suas carteiras, atentos às palavras dos professores, submetidos aos livros didáticos, observados pelos Conselhos de Classes, exigidos por conhecimentos específicos e pressionados por um sistema que visa no seu discurso oferecer promoção social mas que, na verdade, oferece uma socialização adaptada às normas de convivência ditadas por seu grupo social.

Amaral (2006), no artigo "Encontros com professores e alunos de uma escola estadual do Ensino Médio", salienta que a escola, ao insistir em um modelo tradicional de ensino, parece não estar acompanhando as mudanças da sociedade ocidental: "limita-se a ensinar, sem levar em consideração que a subjetividade e a cultura dos jovens têm outras referências além da escola e da família - o que impõe, por sua vez, novas exigências no campo da relação entre as gerações, da participação e expressão juvenis e mesmo do interesse pelo conhecimento -, (a escola) acaba se tornando palco muito mais de confronto e mal-estar do que de um intercâmbio propriamente enriquecedor" (AMARAL, 2006:81-82).

A escola poderia adquirir uma função transformadora, se fosse um local onde não se privilegiasse o adestramento de crianças e jovens conformados e submetidos às leis da vida, apenas atualizados em novos hábitos e técnicas. Neste caso, o aluno deixa de se perceber 
como existente em um universo onde a educação e a instrução façam sentido e estejam conectadas com a sua vida.

Diz Sara Paín (1996), a esse respeito, que um dos problemas difíceis para a Pedagogia é a relação entre a construção do conhecimento por parte do indivíduo e a constituição do sujeito pelo conhecimento. O sujeito não é sujeito até que conheça. É sujeito porque conhece, e é assujeitado a esse conhecimento. Através do conhecimento, ele se constitui como ser humano e vai poder se definir como sujeito, como aquele lugar não repetível que cada um considera seu destino. Talvez esta seja a resposta à questão suscitada pela mãe de Miriam; “que cultura serve, serve. Só não sei para quê!”. É na cultura que o sujeito se conhece e se constitui como sujeito, integrante de um grupo sociocultural.

Por fim gostaríamos de voltar no tempo e estar novamente com a mãe de Miriam. Talvez agora possamos conversar com ela sobre sua cultura, seus significados, suas dúvidas e acertos, valores, e contar o quanto ela nos ajudou com a sua reflexão tão sincera, e dizer que ter cultura é recriar o mundo em cada um de nós.

Acreditamos, por fim, que a escola ao abrir suas portas para a realização da presente pesquisa, também possa se beneficiar dessa escuta atenta às necessidades daqueles para quem a escola pretendeu dirigir seus ensinamentos. 


\section{BIBLIOGRAFIA}

ADLER, Laura. Nos passos de Hannah Arendt. RJ: Record, 2007.

ADLER, Alfred. In: La Taille. Vergonha: a ferida moral. Petrópolis, RJ: vozes, 2002.

ADORNO, Theodor W. \& HORKHEIMER, Max. Dialética do esclarecimento: fragmentos filosóficos. Rio de Janeiro: Jorge Zahar, 1991.

ALMEIDA E SILVA, M.C.. Em busca de uma fundamentação teórica para a psicopedagogia. Rio de Janeiro: Nova Fronteira, 1998.

AMARAL, M. G. T. do. A música e a psicanálise entre os adolescentes. Estilos da Clínica, 2007a, vol. XII, n'. 22, 100-121.

, (org) Culturas Juvenis X Cultura Escolar: como repensar as noções de tradição $e$ autoridade no âmbito da educação? Projeto de Pesquisa apresentado ao Programa "Melhoria do Ensino Público" da FAPESP - Fundação de Amparo à Pesquisa do Estado de São Paulo, out/2006 a setembro/2007b.

(org) Educacao, Psicanálise e Direito: combinações possíveis para se pensar a adolescência na atualidade. São Paulo: Casa do Psicólogo, 2006.

Encontros com professores e alunos de uma escola estadual do ensino médio - uma escuta em que a dimensão objetiva se vê alinhavada pela subjetividade dos atores. Em: Amaral, M. do (org). Educação, Psicanálise e Direito - combinações possíveis para se pensar a adolescência na atualidade. São Paulo: Casa do Psicólogo, 2005, pp. 79-99.

A adolescência na contemporaneidade - reflexões sobre a vida danificada. In: Educação e Psicanálise - história, atualidade e perspectivas. São Paulo: Ed. Casa do Psicólogo, 2003, pp. 195-215.

O espectro de Narciso na modernidade: de Freud a Adorno. São Paulo: Estação Liberdade, 1997.

ANDRÉ, MARLI E. D. de. A pesquisa no cotidiano escolar. In: FAZENDA, Ivani. Metodologia da pesquisa educacional. São Paulo: Cortez Editora, 1989, p. 35-58.

ANDRÉ, MARLI E. D. de. Questões do cotidiano na escola de $1^{o}$ grau. São Paulo: FDE, 1991, (série Idéias, n 11. pgs. 69-81).

ANTUNES, Angela. Leitura do mundo no contexto da planetarização: por uma pedagogia da sustentabilidade. Tese de Doutorado. São Paulo, FE_USP, 2002.

APPLE, Michael W. Educação e poder. Porto Alegre: Artes Médicas, 1989 , . Política cultural e educação. São Paulo: Cortez, 2000

AQUINO, Julio Groppa. Do cotidiano escolar: ensaios sobre a ética e seus avessos. São Paulo: Summus, 2000. 
ARCHAMBAULT, R.D. Educação e análise filosófica. São Paulo: Saraiva, 1979.

ARENDT, Hanna. Entre o passado e o futuro. $2^{\text {a }}$ ed. São Paulo: Perspectiva, 1979.

ÁRIÈS, Philippe. História Social da Criança e da Família. RJ: LTC, 1978.

AZANHA, José Mário Pires. Educação: alguns escritos. São Paulo: Companhia Editora Nacional, 1987.

AZANHA, José Mário Pires. Educação: temas polêmicos. São Paulo: Martins Fontes, 1995.

AZEVEDO, Fernando de. A Cultura brasileira. SP: Melhoramentos, Ed. USP, 1971, p.29

AZEVEDO, R. Somos todos cristãos. São Paulo: Abril. Revista Veja Ed. 1988, ano 39, $n^{\circ} 52$, 27 de dezembro de 2006.

BANTOCK, G. H. La escuela em La sociedad industrial. Buenos Aires: Paidos, 1971.

, in: FORQUIN, Jean Claude. Escola e cultura: as bases sociais e epistemológicas do conhecimento escolar. Porto Alegre: Artes Médicas, 1993.

BARBOSA, Maria Carmen Silveira. Culturas escolares, culturas de infância e culturas familiares. As socializações e a escolarização no entretecer destas culturas. Educ. Soc. , Campinas, vol. 28, n.100 - Especial, p. 1059-1083, out. 2007

Maria Carmen Silveira. Por amor e por força - rotinas na Educação Infantil. Porto Alegre: Artmed, 2006.

BECCHI, Egle \& JULIA, Dominique. Histoire de l'enfance en Occident. (org.) 2. Du XVIII siècle à nos jours. Paris: ed. Seuil, 1998.

BEEVOR, A. A Batalha pela Espanha, RJ: Record, 2007.

BENEDICT, Ruth. O crisântemo e a espada. São Paulo : Perspectiva, 1972.

BÉNÉTON, Philippe. Histoire de mots: culture et civilisation. Paris: Presses de la fondation nationale des sciences politiques, 1975.

BLOOM, Harold. Shakespeare: a invenção do humano. Rio de Janeiro: Objetiva, 2000.

BONDIA, Jorge Larrosa. Nota sobre a experiência e o saber da experiência. Leituras SME número 4 - julho 2001. Textos subsídios ao trabalho pedagógico das unidades da rede municipal de Educação de Campinas - FUMES.

BOSI, Alfredo. Cultura brasileira e culturas brasileiras. IN: Dialética da Colonização. SP: Cia das Letras, 2008, p.308-345.

, Alfredo. Colônia, Culto e Cultura. . IN: Dialética da Colonização. SP: Cia das Letras, 2008, p. 11-63.

BOSI, Ecléa. Problemas ligados à cultura das classes pobres. IN E.VALLE \& J. J. QUEIROZ (orgs.), A cultura do povo. São Paulo: Cortez - EDUC, 1988, p. 25-39. 
BOTO, Carlota. Civilizar a infância na Renascença: estratégia de distinção de classe.

Cadernos da Pedagogia ano I Volume 01 Janeiro/Julho de 2007a.

A forma escolar de civilização: golpes e movimentos. Rev. Educação Especial Grandes Temas n.1: Violência e Indisciplina, São Paulo: Ed. Segmento, 2007b, p.36-45

, A civilização escolar como projeto político e pedagógico da modernidade: cultura em classes, por escrito. Caderno Cedes 61, Campinas: v.23,n.61,dez. 2003, p.378-397.

, O desencantamento da criança: entre a Renascença e o Século das Luzes. In: FREITAS, M.C. ; KUHLMANN, M.. (Org.). Os intelectuais na história da infância. São Paulo: Cortez, 2002, v. , p. 11-60.

Por uma ética em profissão: rumo a uma nova paideia. Interface: Comunicação, Saúde, Educação. v.6. nº10. Botucatu: Fundação UNI, 2002. p.9-25.

A escola do homem novo: entre o Iluminismo e a Revolução Francesa. 1. ed. São Paulo: UNESP, 1996, 212 p.

BOURDIEU, Pierre, [1979b]. A distinção: crítica social do julgamento. São Paulo, Edusp, 2008.

, [1989] Poder simbólico. RJ: Bertrand Brasil, 2007.

Escritos de Educação. Petrópolis: Vozes, [1998]. (Organização de Nogueira, Maria Alice \& Catani, Afrânio), 2005.

[1966]. A escola conservadora. In: NOGUEIRA, M. A. \& CATANI, A. (orgs.). Escritos de educação. Petrópolis, RJ: Vozes, 2005. $7^{\text {a }}$ ed., p.39 - 64.

, [1978]. Classificação, desclassificação, reclassificação. In: NOGUEIRA, M. A. \& CATANI, A. (orgs.). Escritos de educação. Petrópolis, RJ: Vozes, 2005. $7^{\text {a }}$ ed., p. 145183.

[1979a]. Os 3 estados do capital cultural. In: NOGUEIRA, M. A. \& CATANI, A. (orgs.). Escritos de educação. Petrópolis, RJ: Vozes, 2005. $7^{\text {a }}$ ed., p. 71-79.

[ [1980]. O capital social-notas provisórias. In: NOGUEIRA, M. A. \& CATANI, A. (orgs.). Escritos de educação. Petrópolis, RJ: Vozes, 2005. $7^{\text {a }}$ ed., p. 65-69.

,[1990]. Coisas ditas. SP: Brasiliense, 2004

[1994] Razões Práticas: Sobre a teoria da ação. Campinas, SP: Papirus, 1996. 1989.

La noblesse d'Etat : grandes ecoles et esprit de corps. Paris: Les Editions de Minuit, , [1974] A economia das trocas simbólicas. São Paulo : Perspectiva, 1982.

BOURDIEU, Pierre, \& PASSERON, Jean-Claude [1970]. A reprodução: elementos para uma teoria do sistema de ensino. Rio de Janeiro: F. Alves, 1992, 3. ed. 
\& PASSERON, J.C. [1964]. Les héritiers, les étudiants et la culture. Paris: Les

Éditions de Minuit, 1985.

BRANDÃO, ZAIA. Pesquisa em educação: conversas com pós-graduandos. Rio de Janeiro: Ed. PUC-Rio; São Paulo: Loyola, 2002.

BREAL, in: Fernando de Azevedo. A Cultura brasileira. SP: Melhoramentos, Ed. USP, 1971, p.29

BURNS, Edward. História da Civilização Ocidental - do homem das cavernas até a bomba atômica. RJ: Ed. Globo, 1963, $2^{\mathrm{a}}$ ed.

CAMPOS, Andrelino. Do quilombo à favela - a produção do 'espaço criminalizado' no Rio de Janeiro. RJ: Bertrand Brasil, 2005.

CANCLINI, Néstor García. Culturas híbridas. SP: Editora da USP, 1998

CARVALHO, José Sérgio Fonseca de. Construtivismo: uma pedagogia esquecida da escola. Porto Alegre: Artmed Editora, 2001.

CASTRO, BEATRIZ MACARRO (F. I.). História de la congregacion de las Hijas de Jesús. Publicação interna, vol. 1, 1987.

CASTRO, Marilita L. C. de. O mal-estar na civilização: atualidade de um texto. Texto apresentado em seminário realizado no Instituto para o ensino e formação de psicanalistas da SPP (Sociedade Paraibana de Psicanálise). João Pessoa: Paraíba, maio 1999.

CAVALCANTI, Tereza Maria Pompéia. Desejo e poder - o processo de mudança de clientela de uma escola: da classe média/alta para a classe popular. (monografia de conclusão de curso). Depto de Psicologia - PUC/Rio, 2003.

CAZELLI, Sibele.; FRANCO, Creso. PONTIFÍCIA UNIVERSIDADE CATÓLICA DO RIO DE JANEIRO Departamento de Educação. Ciência, cultura, museus, jovens e escolas: quais as relações?. 2005. 260 f. Tese (Doutorado em Educação)-Pontifícia Universidade Católica do Rio de Janeiro, Rio de Janeiro, 2005.

CHARLOT, BERNARD. Da relação com o saber: elementos para uma teoria. Porto Alegre: Artes Médicas Sul, 2000.

CORDEIRO, Jaime Francisco Parreira. Projetando a mudança: o novo e o tradicional na educação brasileira (anos 70 e 80). Tese de Doutorado. [mimeografada] São Paulo: Faculdade de Educação da USP, 1999.

CORTELLA, Mario Sérgio. A escola e o conhecimento: fundamentos epistemológicos e políticos. $4^{\text {a }}$ ed. São Paulo: Cortez/Instituto Paulo Freire, 2001.

DAIRELL, Juarez. (org.) A escola como espaço sócio-cultural. IN: Múltiplos olhares sobre Educação e Cultura. Belo Horizonte, MG: UFMG, 1996, p. 137-161..

DEMO, Pedro. Educar pela pesquisa. Campinas, SP: Autores Associados, 2002, 5. ed. (Coleção educação contemporânea) 
DORTIER, Jean-François. Les idées purês n'existente pas. Sciences humaines 'La oeuvre de Pierre Bourdieu’. Numéro Spécial Pierre Bourdieu, 2002, p.13-15.

DUBET, François. O que é uma escola justa? A escola das oportunidades. SP: Cortez, 2008. , François. "O que é uma escola justa?" In: Cadernos de Pesquisa, v.34.n.123.p.539555.set./dez.2004 2003a. François. "A escola e a exclusão" In: Cadernos de Pesquisa, v.34.n.119.p.29-45.julho , François. As desigualdades multiplicadas. Ijuí: Ed. Unijuí, 2003b.

François. Quando o sociólogo quer saber o que é ser professor. Entrevista concedida à Peralva, Angelina Teixeira \& Sposito, Marília Pontes. Revista Brasileira de Educação, mai/jun/jul/ago 1997 n $^{\circ} 5$ e set/out/nov/dez 1997 [online], nº 6, p. 222-231.

, François. Sociologia da experiência: Lisboa: Instituto Piaget 1996.

DUCH, Lluís. La educación y la crisis de la modernidad. Barcelona: Paidós, 1997.

DUFFY, Eamon. Santos \& Pecadores - história dos papas. SP: Cosac \& Naify ed. , 1998.

DURKHEIM. Education et sociologie. $5^{\text {a }}$.ed. Paris: P.U.F., 1985.

EAGLETON, Terry. A idéia de cultura. SP: Ed. Unesp, 2005.

ELIAS, Norbert. O processo civilizador: uma histórias dos costumes. Vol.1. Rio de Janeiro: Jorge Zahar, 1994.

ELIAS, Norbert. O processo civilizador: formação do Estado e civilização. Vol. 2. Rio de Janeiro: Jorge Zahar, 1993.

FEVORINI, Luciana B. A autoridade do professor: um estudo das representações de autoridade em professores de $1^{o}$ e $2^{o}$ graus. Dissertação (Mestrado em Educação)Universidade de São Paulo, São Paulo, 1998.

FISCHMANN, Roseli. Da linguagem oral à linguagem da hipermídia: reflexões sobre cultura e formação do educador. São Paulo Perspectiva: jun 2000, vol. 14, n 2, p. 12-22.

FOURNIER, Martine. À propôs de... Les héritier, les étudiants et La culture. Sciences humaines 'La oeuvre de Pierre Bourdieu'. Numéro Spécial Pierre Bourdieu, 2002, p. 1516.

FORQUIN, Jean Claude. Escola e cultura: as bases sociais e epistemológicas do conhecimento escolar. Porto Alegre: Artes Médicas, 1993.

FREIRE, Madalena. Educador, educa a dor. SP: Paz e Terra, 2008.

FREIRE, PAULO, 1996. Pedagogia da autonomia: saberes necessários à prática educativa. SP: Paz e Terra, 2002, $21^{\text {a }}$ ed.

FREUD, S. La malaise dans la culture. Paris: Quadrige / PUF, 1995 (reimpressão 2007) 
FREUD, S. Obras psicológicas completas de S. Freud: edição Standard brasileira, vol. XXI. O futuro de uma ilusão, o Mal Estar na Civilização e outros trabalhos (1927-1931). RJ: Imago, 1996.

FREUD, Sigmund. Obras psicológicas completas de Sigmund Freud: edição standard brasileira. Rio de Janeiro: Imago, 1996, v.XXI.

FUKS, Betty Bernardo. Freud e a cultura. RJ: Jorge Zahar ed., 2003.

GAARDER, Jostein. Ei! Tem alguém aí? São Paulo: Companhia das Letrinhas, 1997.

GARCIA, Regina Leite (org.). Método: pesquisa com o cotidiano. Rio de Janeiro, DP\&A, 2003.

GATTI, Bernadete Angelina. A construção da pesquisa em Educação no Brasil. Brasília, DF: Plano, 2002 (série Pesquisa em Educação; v. 1).

GAUTHIER, C. [et al.]. Por uma teoria da Pedagogia. Ijuí: RS: UNIJUÍ, 1998 (coleção fronteiras da educação).

GEERTZ, Clifford. A interpretação das culturas. RJ: LTC, 1989.

GIROUX, HENRY. Escola crítica e política cultural. São Paulo: Cortez: autores Associados, 1987 (coleção polêmicas do nosso tempo; 20)

GOMES, Jerusa V. IN: PATTO, M. H. S. A produção do fracasso escolar: histórias de submissão e rebeldia. São Paulo: Casa do Psicólogo, 1999, prefácio da $2^{\mathrm{a}} \mathrm{Ed}$. de Jerusa Vieira Gomes.

GREEN, Bill \& BIGUM, Chris. Alienígenas na sala de aula. In: SILVA, Tomaz Tadeu (org.). Alienígenas na sala de aula: uma introdução aos estudos culturais em educação. Petrópolis: Vozes, 1995.

GUSDORF, Georges. Professores para quê?? São Paulo: Martins Fontes, 1995.

HAMAD, Nazir. A criança adotiva e suas famílias. RJ: Companhia de Freud, 2002.

HANNOUN, Hubert. Educação: certezas e apostas. São Paulo: UNESP, 1998.

HELLER, Agnes. Entrevistada por Francisco Ortega. Rio de Janeiro: Ed. VERJ, 2002. O cotidiano e a história (1970). Rio de Janeiro: Paz e Terra, 1989. Aristoteles y El mundo antiguo. Barcelona: Ed. Península, 1983.

HERSCHMANN, M. O funk e o hip hop invadem a cena. R.J: Ed.da UFRJ, 2000.

HIJAS DE JESUS. Um camino entre dos fechas. 1871 - 1971. Espanha: Salamanca, 1976. Impresso na Espanha na Gráfica Ortega. ISBN: 84-400-2046-5.

HOBSBAWN, Eric J. [1977] A Era das Revoluções: 1789-1848. São Paulo: Paz e terra, 2007, $21^{\mathrm{a}}$ ed. 
HORKHEIMER, M. e ADORNO, T. W. Cultura e Civilização In: Temas básicos da

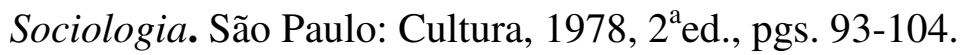

JULIA, Dominique. A cultura escolar como objeto histórico. Revista Brasileira de História da Educação. SBHE - Sociedade Brasileira de História da Educação. nº ${ }^{\circ}$. Campinas: Editora Autores Associados, 2001.p. 9-43.

KANT, I. Idéia de uma história universal de um ponto de vista cosmopolita, 1986.

LAHIRE, Bernard. A cultura dos indivíduos. Porto Alegre, Artmed, 2006.

LAJONQUIÈRE, Leandro de. A infância que inventamos e as escolas de ontem e de hoje. In: Estilos de clínica. Volume VIII. nº 15, 2003. p. 140-159.

LAPLANTINE, François. Aprender antropologia. Rio de Janeiro: Brasiliense, 2003.

LA TAILLE, Yves de. Vergonha: a ferida moral. Petrópolis, RJ: vozes, 2002.

LARROSA BONDIA, Jorge. Nota sobre a experiência e o saber da experiência. Leituras SME - número 4 - julho 2001. Textos subsídios ao trabalho pedagógico das unidades da rede municipal de Educação de Campinas - FUMES.

LÉVY, Pierre. As tecnologias da inteligência: o futuro do pensamento na era da informática. Rio de Janeiro: Editora 34, 1996.

LUDKE, Menga \& ANDRÉ, Marli E. D. A. Pesquisa em educação: abordagens qualitativas. São Paulo: EPU, 1986. (temas básicos de educação e ensino)

MACEDO, C. "Algumas observações sobre a cultura do povo". in E.VALLE \& J. J. QUEIROZ (orgs.), A cultura do povo. SP: Cortez / EDUC. 1979.

MACHADO, J.S. O potencial interpretativo das análises tecnológicas: um exemplo amazônico. Rev. do Museu de Arqueologia e Etnologia, São Paulo, 15-16: 87-111, 20052006.

MAMEDE-NEVES, Maria Apparecida C. O Fracasso escolar e a busca de soluções alternativas : a experiência do NOAP /.Petropolis, RJ : Vozes, 1987.

MARTINEZ, Maria Helena. De volta à escola: escolarização e formas de sociabilidade dos jovens das camadas populares. Rio de Janeiro, 2006; 229 p. Tese de doutorado - Depto. de Educação, Pontifícia Universidade Católica do Rio de Janeiro.

MATTOS, Carmen Lúcia G. de. O conselho de classe e a construção do fracasso escolar. Educação e pesquisa [online], 2005, v. 31, n.2, pp. 215-228.

McLAREN, Peter. Rituais na escola: em direção a uma economia política de símbolos e gestos na educação. Petrópolis, RJ: Vozes, 1991.

MEDEIROS, Verena Giglio de.; BRANDÃO, Zaia. PONTIFÍCIA UNIVERSIDADE CATÓLICA DO RIO DE JANEIRO Departamento de Educação. Clima escolar: um estudo sociológico de uma instituição pública de excelência. 2007. Dissertação (Mestrado em Educação)-Pontifícia Universidade Católica do Rio de Janeiro, Rio de Janeiro, 2007. 
MEIRIEU, Philippe. A pedagogia entre o dizer e o fazer: a coragem de começar. Porto Alegre: Artmed, 2002.

MELlO, S. L. de. In: Patto, M. H. Souza. A produção do fracasso escolar: histórias de submissão e rebeldia. São Paulo: Casa do Psicólogo, 1999.

MIALARET, Gaston. As ciências da educação. $2^{\mathrm{a}}$ ed. Lisboa: Moraes, 1980.

MIALARET, Gaston. Introdução à pedagogia. São Paulo: Atlas, 1977.

MILLER, Alice. O drama da criança bem dotada. São Paulo: Summus, 1986.

MONTEROLA PACHECO E ASTUDILLO CASTRO (2002). De una escuela que enseña a una escuela que aprende: el aprendizaje de los buscadores. Chile: Boletin de investigacion educacional, vol.17:82-100, 2002.

MONTOYA, Adrian Oscar Dongo. Piaget e a criança favelada: epistemologia genética, diagnóstico e soluções. Petrópolis, RJ: Vozes, 1996.

NAGLE, Jorge. Educação e linguagem: para um estudo do discurso pedagógico. São Paulo: Edart, 1976.

NICOLACI-DA-COSTA, Ana Maria. Sujeito e cotidiano; um estudo da dimensão psicológica do social. Rio de Janeiro: Campus, 1987.

NIETZSCHE, Friedrich. Escritos sobre educação. Sao Paulo : Loyola, 2003

NOGUEIRA, Maria Alice \& CATANI, Afrânio (orgs.). Pierre Bourdieu - Escritos de Educacao. Petrópolis: Vozes, 1998.

NÓVOA, A. (org.) Profissão professor. Porto: Porto Editora, 1995.

NÓVOA, António. Relação escola-sociedade: “novas respostas para um velho problema.” In: Formação de professores. Ricardo Ribeiro (org). São Paulo: Editora UNESP, 1998.

OLIVEIRA, Romualdo Portela de. Da universalização do ensino fundamental ao desafio da qualidade: uma análise histórica. Educ. Soc. , Campinas, vol. 28, n.100 - Especial, p. 661690, out. 2007

ORTEGA, Y. Gasset. A rebelião das massas. Rio de Janeiro, Livro Ibero-Americano, 1959.

ORTIZ, Renato. 1994. Mundialização e Cultura. S.P.: Brasiliense, 2006a.

1988. A moderna tradição brasileira - cultura brasileira e indústria cultural. S.P.: Brasiliense, 2006b.

PAIN, S. Diagnóstico e tratamento dos problemas de aprendizagem. Porto Alegre: Artes Médicas, 1985.

, Subjetividade e Objetividade. São Paulo: CEVEC, 1996.

PAIXÃO, Lea Pinheiro Significado da escolarização para um grupo de catadoras de um lixão. Cadernos de Pesquisa, São Paulo, v. 35, n. 124, p. 141-170, 2005. 
PATTO, Maria Helena Souza. Exercícios de indignação: escritos de educação e psicologia. São Paulo: Casa do Psicólogo, 2005. , (org). A introdução à psicologia escolar. São Paulo: Casa do Psicólogo, 1997, 3 ed. 1990. A produção do fracasso escolar: histórias de submissão e rebeldia. São Paulo: Casa do Psicólogo, 1999.

PATTO, Maria Helena Souza \& FRAYSE-PEREIRA, João (orgs). Pensamento cruel humanidades e ciências humanas: há lugar para a psicologia? São Paulo: Casa do Psicólogo, 2007.

PEREIRA, Gilson M. A improvável trajetória de um sociólogo enervante. Revista de Educação 'Bourdieu pensa a educação' p. 6-15. SP: Segmento, $\mathrm{n}^{\circ}$ 5, 2007, biblioteca do professor.

PERRENOUD, P. 10 novas competências para ensinar. Porto Alegre: Artes Médicas, 2000.

PETERS. The concept of education. Londres: Routledge, 1968.

PIAGET, Jean. O juizo moral na criança. São Paulo: Summus, 1994.

PIAGET, Jean,. A equilibração das estruturas cognitivas: problema central do desenvolvimento. Rio de Janeiro: Zahar, 1976.

POSTIC, Marcel. A relação pedagógica. Lisboa: Padrões Culturais Ed., 2007.

POSTMAN, Neil. O desaparecimento da infância. Rio de Janeiro: Graphia, 1999.

PRADO, Tomas. Análise do ensaio de Jorge Larrosa: Experiência e Paixão, 2007, p. 1-3.

QUINTANA, Mario. 1973. Caderno H. RJ: Globo, 2006.

RAMOS, Arthur. Introdução à antropologia brasileira (1943). RJ: Casa do estudante, 1962. In: Bosi, Alfredo. Dialética da colonização. SP: Cia das Letras, 2001.

REBOUL, Olivier. La philosophie de l'éducation. Paris: Presses Universitaires de France, 1989.

ROUANET, P. S. Mal-estar na Modernidade. São Paulo: Cia das Letras, 1993.

ROUSSEAU, In: HORKHEIMER, M. e ADORNO, T. W. Cultura e Civilização In: Temas

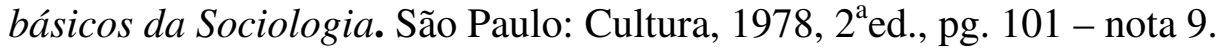

SACRISTÁN, G. Poderes instáveis em educação. São Paulo: Artes Médicas, 1999.

SAMPAIO, Carmen Sanches. Compreender o compreender das crianças em seus processos alfabetizadores. In: GARCIA, Regina Leite (org.). Método: pesquisa com o cotidiano. Rio de Janeiro, DP\&A, 2003, p. 17 - 42.

SCHEFFLER, I. A linguagem da educação. São Paulo: Saraiva, 1974. 
SILVA, Jailson de Souza \& BARBOSA, Jorge Luiz. Favela - alegria e dor na cidade. RJ: Senac Rio, 2005.

SILVA, L.H. (org). A escola cidadã no contexto da globalização. Petrópolis: Vozes, 1998.

SILVA, Maria Laís Pereira da. Favelas cariocas - 1930-1964. RJ: Contraponto, 2005.

SNYDERS, Georges / LÉON, Antoine / GRÁCIO, Rui. Correntes actuais da pedagogia. Lisboa: Livros Horizonte, 1984.

SNYDERS, Georges. A alegria na escola. Rio de Janeiro: Paz e Terra, 1995.

SNYDERS, Georges. Alunos felizes: reflexão sobre a alegria na escola a partir de textos literários. 2a .ed. São Paulo: Paz e Terra, 1996.

SNYDERS, Georges. Feliz na universidade: estudo a partir de algumas biografias. Rio de Janeiro: Paz e Terra, 1995.

SOARES, Magda Becker. Linguagem e escola - uma perspectiva social. São Paulo: Ática, 1986.

SPENGLER. In: HORKHEIMER, M. e ADORNO, T. W. Cultura e Civilização In: Temas

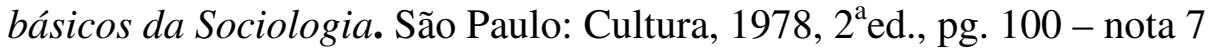

TEDESCO, J.C. O novo pacto educativo: educação, competitividade e cidadania na sociedade moderna. São Paulo: Ática, 1998.

TEPEDINO, Cristina de Azeredo Lopes. Cotidiano escolar e mudança sociocultural: a experiência do Colégio Stella Maris. Dissertação de mestrado de Educação, PUC-Rio, 2007.

THIN, Daniel. Para uma análise das relações entre famílias populares e escola: confrontação entre lógicas socializadoras. Revista Brasileira de Educação, v. 11 n. 32 maio/ago. 2006, p. 211-225.

TOMERO, MARIA DEL CARMEN DE FRIAS (F. I.). Aonde Deus te chame. Espanha, Salamanca: Ed. Sígueme S.A. 1990. Impresso no Brasil: Gráfica Fumarc - tradução de Adair Alice de Mattos \& Maria Luíza Campos do Amaral (F.I)

VALLE, E. \& QUEIROZ, J.J. (1979) A cultura do povo. SP: Cortez / EDUC., 1988.

VASCONCELLOS, Ana Celina A. A linguagem Logo e o computador: da eficiencia de ser um instrumento psicopedagogico. 1992. 118f. Dissertação (Mestrado) - Pontificia Universidade Catolica do Rio de Janeiro, Departamento de Educação.

VELHO, G. Juventudes, projetos e trajetórias na sociedade contemporânea. In: ALMEIDA, M.I.M de e EUGENIO, F. (org) Culturas jovens - novos mapas do afeto. RJ: Jorge Zahar, 2006, p.192-200.

ZALUAR, Alba \& ALVITO, Marcos (org.) Um século de Favela. Rio de Janeiro : FGV, 1988. 
ZELCER, Mirta. Novas lógicas e representações na construção de subjetividades: a perplexidade na instituição educativa" In: Amaral (org.), Educacao, Psicanálise e Direito: combinações possíveis para se pensar a adolescência na atualidade. São Paulo: Casa do Psicólogo, 2006, p. 101-132. 
ANEXO: Documentos lidos para a confecção da história da Madre Cândida, não citados diretamente na tese

AMADO, Maria Del Carmen Simón. Em La iglesia, para mejor servir.

BARBOSA, Maria Amélia de Almeida. Ao fim do mundo iria eu... BH: Imprimatur, 1984.

CASTRO, Beatriz Macarro. De La intuicion... a La vida: Del ayer AL hoy em La misíon educativa de lãs hijas de Jesus em España. Valladolid, 2002, Espanha, Salamanca, 2002.

CASTRO, Beatriz Macarro. Ruta...Invitación. Espanha, Salamanca, 1982.

FRIAS, Maria Del Carmen de. Biografia de La sierva de Dios. M. Candida de Jesus (Juana Josefa Cipitria y Barriola). Fundadora de La congregacion de lãs hijas de Jesus (31 mayo 1845- 9 agosto 1912). (Hijas de Jesus- postulacion de lãs causas de cananizacion, Roma, 1988). Espanha, Salamanca, 1988.

FRIAS, Maria Del Carmen de. O milagre para sua Beatificação. Série Virtudes, n.10: O milagre para sua beatificação.

FRIAS, Maria Del Carmen de. Venerable por su caridade com Dios y com los hombres. Série Virtudes, n.3: Caridad.

FRIAS, Maria Del Carmen de. Venerable por su Fe y su esperanza. Série Virtudes, n.2: Fe y esperanza.

FRIAS, Maria Del Carmen de. Venerável por seu amor a Deus e ao próximo. Série Virtudes, n.3: Amor.

FRIAS, Maria Del Carmen de. Venerável por sua castidade e sua pobreza. Série Virtudes, n.6: Castidad y pobreza.

FRIAS, Maria Del Carmen de. Venerável por sua fortaleza y su tempolanza. Série Virtudes, n.5: Fortaleza y Templanza.

FRIAS, Maria Del Carmen de. Venerável por sua humildade. Série Virtudes, n.8

FRIAS, Maria Del Carmen de. Venerável por sua obediência. Série Virtudes, n.7: Obediência.

FRIAS, Maria Del Carmen de. Venerável por sua prudência e sua justiça. Série Virtudes, n.4: Prudência e Justiça.

GONZALEZ, Inés Laso. De Juana Josefa Cipitria a Cândida Maria de Jesus. San Sebastian, 1978 (sem editora).

MUÑOZ, Cristobal Robles. Cento e cinqüenta anos depois. Série Virtudes, n.9: Candida M. de Jesus: a memória e as relíquias. Seu perfil humano e espiritual.

PROJETO DO CENTRO POPULAR DE EDUCAÇÃO, 2000. 
REVISTA: Em rede - Filhas de Jesus. Ano III, n.03, 2008.

URBINA, Ir. Ortiz de. Toda e só para Deus: a serva de Deus - M. Candida M. de Jesus fundadora das religiosas "Filhas de Jesus". Congregação das Filhas de Jesus BH-MGBrasil, 1959.

VIRSEDA, Maria Luisa Matamali. Joanita nos conta sua vida. Espanha, Salamanca: 1997.

Sites consultados:

www.favelamemoria.com.br

www.hijasdejesus.org

www.reportersocial.com.br

www.rio.rj.gov.br/ipp 